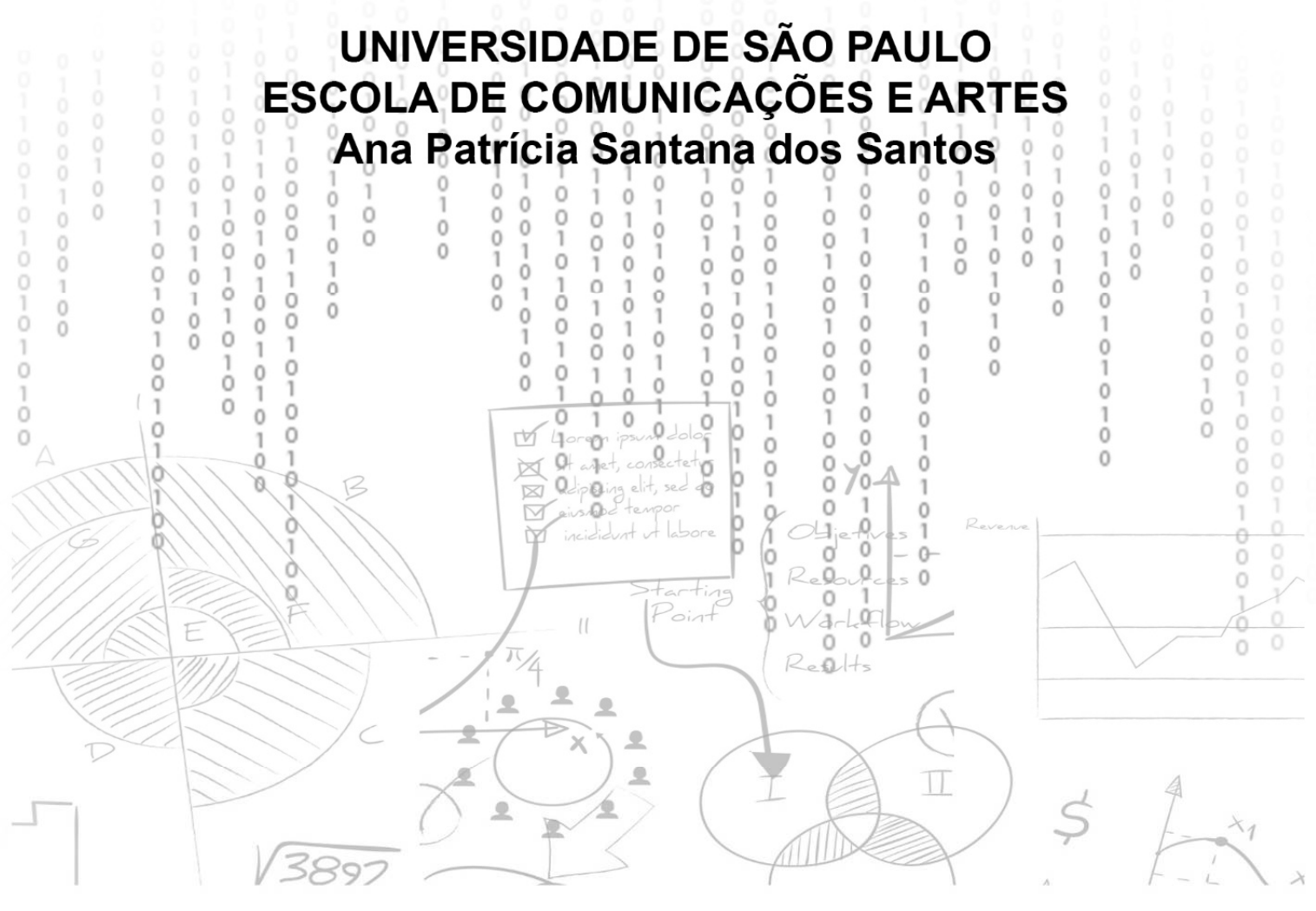

Startups digitais A travessia na Zona Cinzenta

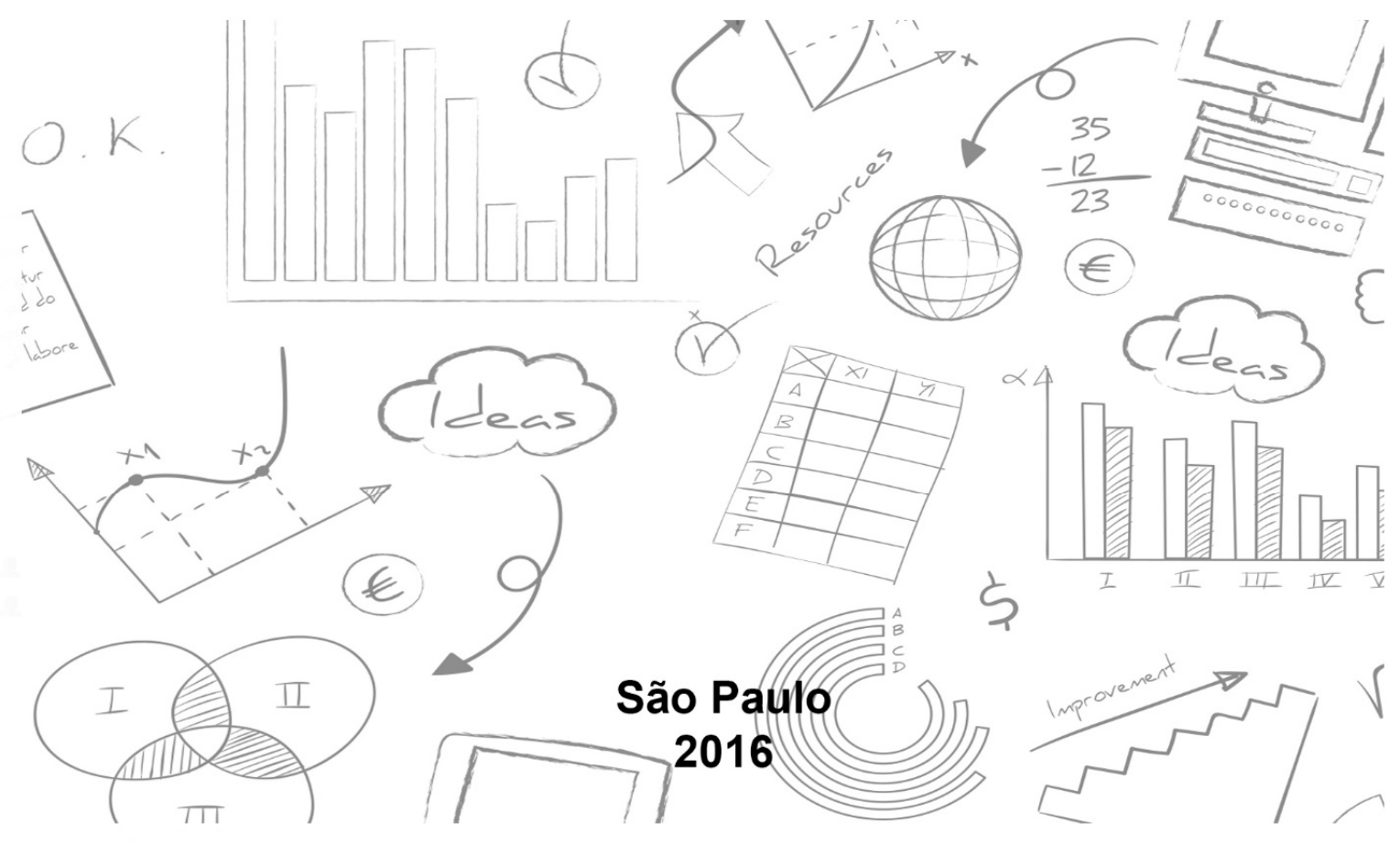


Ana Patrícia Santana dos Santos

\title{
Startups digitais
}

\author{
A travessia na Zona Cinzenta
}

Dissertação apresentada ao programa de Pós-Graduação em Ciências da Comunicação, Área de Concentração Teoria e Pesquisa em Comunicação, Linha de Pesquisa Comunicação e Ambiências em Redes Digitais da Escola de Comunicações e Artes da Universidade de São Paulo, como exigência parcial para a obtenção do título de mestre em Ciências da Comunicação.

Orientador: Prof. Dr. Massimo Di Felice.

São Paulo 
Autorizo a reprodução e divulgação total ou parcial deste trabalho, por qualquer meio convencional ou eletrônico, para fins de estudo e pesquisa, desde que citada a fonte.

Catalogação na Publicação Serviço de Biblioteca e Documentação

Escola de Comunicações e Artes da Universidade de São Paulo Dados fornecidos pelo(a) autor(a)

Santana, Ana Patrícia

Startups digitais: A Travessia na Zona Cinzenta / Ana

Patrícia Santana. -- São Paulo: A. P. Santana, 2016.

213 p.: il.

Dissertação (Mestrado) - Programa de Pós-Graduação em Ciências da Comunicação - Escola de Comunicações e Artes / Universidade de São Paulo.

Orientador: MASSIMO DI FELICE

Bibliografia

1. Startup Digital. 2. Comunicação digital 3. Zona

Cinzenta 4. Empreendedorismo 5. Complexidade de redes. I. DI FELICE, MASSIMO II. Título.

CDD 21. ed. -302.2 
SAntana SAntos, Ana. Startups digitais: A Travessia na Zona Cinzenta. Dissertação apresentada à Escola de Comunicações e Artes da Universidade de São Paulo para obtenção do título de mestre em Ciências da Comunicação. Área de concentração: teoria e pesquisa em comunicação.

Aprovada em: / /

BANCA EXAMINADORA

Prof. (a) Dr. (a): $\quad$ Instituição:

Julgamento: Assinatura:

Prof. (a) Dr. (a): $\quad$ Instituição:

Julgamento: Assinatura:

Prof. (a) Dr. (a): $\quad$ Instituição:

Julgamento: Assinatura:

Prof. (a) Dr. (a): $\quad$ Instituição:

Julgamento: Assinatura: 
Aos meus pais, Vitorino e Joana, por apoiarem incondicionalmente minhas travessias. 


\section{Agradecimentos}

À minha família, por me apoiar na decisão de mais uma vez partir, desta vez, em direção à terra paulistana. Obrigada pelo amor, cuidado e compreensão em todos os momentos de "aperreios" e de necessárias ausências para o desenvolvimento da pesquisa.

Ao meu orientador, Prof. Dr. Massimo de Felice, obrigada por abrir as portas do Atopos para o desenvolvimento deste estudo, me oferecendo a valiosa oportunidade de perseguir os meus sonhos e traçar meus próprios caminhos na cidade "do avesso, do avesso, do avesso, do avesso".

Ao Centro Internacional de Pesquisa Atopos ECA/USP, pela interdisciplinaridade, diversidade de seus integrantes, comprometimento e qualidade dos seus pesquisadores. Um espaço fértil e inquietante que me permitiu buscar novos vôos no meu desejo de investigar a comunicação nas ações empreendedoras.

Aos colegas "atopinos", pelo acolhimento e contribuições valiosas na árdua tarefa do pesquisar. Em especial, à Kayline, por suas sábias palavras sobre a vida; à Raquel, pelo cuidado e atenção; à Fernanda, pelas boas vindas nos meus primeiros momentos desta experiência; à Juliana, pela amizade, pela leitura dos textos e pela generosidade de parar para me ouvir e me fazer acreditar que tudo daria certo.

À Escola de Comunicações e Artes, ao Programa de Pós graduação - PPGCOM e ao apoio fundamental da CAPES - Coordenação de Aperfeiçoamento de Pessoal de Nível Superior, que propiciou o financiamento desta pesquisa.

Aos Novos Idealistas e suas criações, sobre as quais me debrucei durante a realização do trabalho. Em especial Eduardo L'Hotellier, Márcio Boruchowski, Rosi Rodrigues, João Abrassuma, Flávio Pripas, Ricardo Iguchi e Jorge Vargas, pelos encontros, e-mails, cafés, conversas, Skype, telefonemas e hangouts.

Aos amigos Joyce França, pelo companheirismo na minha chegada à São Paulo, e Marcilio Rocha-Ramos, pela amizade preciosa e interlocução inestimável durante a pesquisa, e Sakai, pelo incentivo, leveza e cumplicidade. 
“A situação a bordo era desoladora. O vento ensurdecedor, o mar difícil, roupas encharcadas, muito frio e alguns estragos. Pela frente, uma eternidade até o Brasil. Para trás, uma costa inóspita, desolada e perigosamente próxima. Sabia melhor que ninguém avaliar as dificuldades que eu teria daquele momento em diante. [...] Mas, se tomara essa decisão, não fora sem avaliar os riscos. [...] Se estava com medo? Mais que a espuma das ondas, estava branco, completamente branco de medo. Mas, ao me encontrar afinal só, só e independente, senti uma súbita calma. Era preciso começar a trabalhar rápido, deixar a África para trás, e era exatamente o que eu estava fazendo. Era preciso vencer o medo; e o grande medo, meu maior medo na viagem, eu vencera ali, naquele mesmo instante, em meio à desordem dos elementos e à bagunça daquela situação. Era o medo de nunca partir. Sem dúvida, este foi o maior risco que corri: não partir. Não estava obstinado de maneira cega pela ideia da travessia, como poderia parecer - estava simplesmente encantado." 
RESUMO

- Santana SAntos, Ana. Startups Digitais: A Travessia na Zona Cinzenta. Dissertação apresentada à Escola de Comunicações e Artes da Universidade de são Paulo para obtenção do título de Mestre em Ciências da Comunicação. Área de concentração: Teoria e pesquisa em comunicação. São Paulo, 2016.

As startups digitais ocorrem como um fenômeno da própria Sociedade em Rede e de uma mudança profunda e qualitativa nas relações entre pessoas, espaços e coisas. Seus fluxos produtivos traduzem uma intensa transitividade dos espaços de produção, um protagonismo permanente com novas tecnologias digitais e uma mobilização do corpo como máquina produtiva. Esta pesquisa aborda a criação das startups na sua fase inicial, ou seja, nos momentos de idealizações do pensamento que age, na relação entre ideia e ação, especificando o movimento de travessia dos seus criadores, aqui chamados de Novos Idealistas, num percurso de alta criticidade denominado Zona Cinzenta. A partir dos pontos de ideação-previsão e experimentação-criação, a pesquisa produz reflexos sobre a arte desse empreendedorismo em situação-embrião. Com o objetivo de produzir um tecimento das suas ações na travessia, a pesquisa realiza um acompanhamento de processos nos territórios moventes das startups, desenvolvendo uma cartografia de conceitos que pulsam com intensidade neste transcurso. As teorias que situam o contexto desse novo modo de produzir, configurado pela hegemonização do trabalho imaterial, referenciam os caminhos da pesquisa, situando o conhecimento como principal força produtiva. Para entender esta travessia, a pesquisa navegou nos fazeres das startups, observando de dentro os movimentos de produção, a linguagem e o acionamento das máquinas comunicativas. Ao acompanhar os desejos e expor cases das ações, esta investigação assinala o fenômeno das startups como um novo empreendedorismo marcadamente digital, ecossistêmico e comunicativo.

Palavras-chave. Startup Digital. Produção Imaterial. Zona Cinzenta. Empreendedorismo. Complexidade de Redes. Comunicação Digital. Tecnologia. 


\section{Abstract}

- Santana Santos Ana. Digital Startups: The Passage through the Grey Zone. Dissertation submitted to the School of Communications and Arts of the University of São Paulo to obtain the Master's degree in Communication Sciences. Concentration Area: Theory and research in communication. São Paulo, 2016.

Digital startups occur as phenomena of the Internet Society and a deep and qualitative change in relationships between people, places and things. Their production flows reveal an intense transitivity of production spaces, a permanent leading role with new digital technologies, and mobilization of the body as a productive machine. This research deals with the creation of startups in their initial phase. That is, in those moments of idealization of thoughts that relate idea and action, that specify the movement of their creators, here called New Idealists, on a high criticality path through what is called a Grey zone. Starting from the points of ideation-prediction and experimentation-creation, the research produces reflections on the art of this entrepreneurship in an embryo situation. With the goal of interweaving their actions in this passage, the research performs a monitoring process in areas where startups act, mapping concepts that pulsate with intensity along this course. The theories that contextualize this new production mode, in which immaterial labor dominates, reference the paths of research, placing knowledge as the main productive force. To understand this passage, the research navigated the doings of startups, observing from inside the movements of production, the language, the activation of the communication machines. In following the desires and exposing 'cases' of actions, this research points to the phenomenon of startups as a new entrepreneurship, markedly digital, ecosystemic and communicative.

Key-words. Digital Startup. Immaterial production. Grey Zone Entrepreneurship Network Complexity . Digital Communication. Technology 


\section{LISTA DE FIGURAS E QUADROS}

\section{FIGURAS}

\section{Capítulo I: As Startups Digitais}

$\begin{array}{lll}\text { Figura } 1 \quad \text { Boo-box: impulsão de vendas por click } & 15\end{array}$

Figura 2 Prosas: Conexão no Terceiro Setor 16

Figura 3 Wairon: Compartilhando Ativos em Rede 17

Figura 4 GetNinjas: Marketplace Horizontal Para Serviço 18

$\begin{array}{lll}\text { Figura } 5 & 19\end{array}$

$\begin{array}{lll}\text { Figura } 6 & \text { Demo Day }\end{array}$

Capítulo II: As redes

$\begin{array}{lll}\text { Figura } 7 & \text { Modelos de redes } & 30\end{array}$

Figura 8 Diagramas das Redes de Baran $\quad 32$

\section{Capítulo III: Caracterização das Startups}

Figura 9 Extraordinário Crescimento do WhatsApp 48

Figura $10 \quad$ Startups Exponenciais $\quad 51$

Figura $11 \quad$ Os números das Startups Brasileiras $\quad 54$

Figura 12 Mortalidade das Startups no Brasil 55

$\begin{array}{lll}\text { Figura } 13 & \text { O Ecossistema Empreendedor } & 57\end{array}$

Figura $14 \quad$ O Ecossistema de Startups Digitais 58

Figura 15 Ranking Global de Ecossistema de Startups 59

Figura $16 \quad$ Ciclo de Vida das Startups $\quad 60$

Figura 17 Diagrama de Lançamento de Novos Produtos 62

Figura 18 Desenvolvimento de Clientes e o Ciclo das Startups 63

Capítulo IV: As startups: fenômeno da imaterialidade

Figura 19 Fin-techs: Novos Corpos no Mercado Financeiro 71

$\begin{array}{lll}\text { Figura } 20 & \text { As Fin-techs no mercado B2B } & 72\end{array}$

$\begin{array}{lll}\text { Figura } 21 & \text { As Fin-techs no mercado B2C } & 73\end{array}$

$\begin{array}{lll}\text { Figura } 22 & \text { As Startups e as grandes empresas } & 74\end{array}$

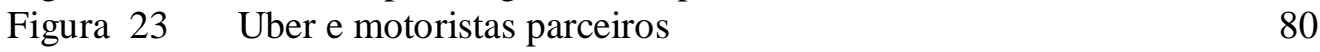

$\begin{array}{lll}\text { Figura } 24 & \mathrm{O} \text { conceito Uber } & 84\end{array}$

\section{Capítulo V: Pesquisando na Zona Cinzenta}

$\begin{array}{lll}\text { Figura } 25 & \text { Dispositivo de Pesquisa } & 91\end{array}$

\section{Capítulo VI: A Zona Cinzenta}

$\begin{array}{lll}\text { Figura } 26 & \text { Delimitação da Zona Cinzenta } & 108\end{array}$

$\begin{array}{lll}\text { Figura } 27 & \text { Portal Minha Vida } & 111\end{array}$

$\begin{array}{lll}\text { Figura } 28 & \text { Plataforma de Inteligência Coletiva Kekanto } & 113\end{array}$

$\begin{array}{lll}\text { Figura } 29 & \text { Ed-tech Qmagico } & 114\end{array}$ 


\section{Capítulo VII: Ponto de Ideação}

$\begin{array}{lll}\text { Figura } 30 & \text { Meetup com tecnologia e empreendedorismo } & 123\end{array}$

$\begin{array}{lll}\text { Figura } 31 & \text { Startup Weekend no Brasil } & 127\end{array}$

\section{Capítulo VIII: Ponto de Experimentação}

$\begin{array}{lll}\text { Figura } 32 & \text { Protótipo Funcional da Boo-box } & 130\end{array}$

$\begin{array}{lll}\text { Figura } 33 & \text { Produção de Redes das Startups } & 132\end{array}$

$\begin{array}{lll}\text { Figura } 34 & \text { Programas de aceleração no Brasil } & 137\end{array}$

$\begin{array}{lll}\text { Figura } 35 & \text { Processo seletivo para programa de aceleração } & 138\end{array}$

$\begin{array}{lll}\text { Figura } 36 & \text { Grandes empresas investem em co-working para startups } & 140\end{array}$

$\begin{array}{lll}\text { Figura } 37 & \text { Novos idealistas produzem conteúdo } & 142\end{array}$

$\begin{array}{lll}\text { Figura } 38 & \text { Postagem da startup em Fanpage } & 146\end{array}$

\section{Quadros}

Quadro $01 \quad$ Ambiências de análise 


\section{SUMÁRIO}

INTRODUÇÃO $\quad 12$

1 AS STARTUPS DIGITAIS 14

$\begin{array}{lll}1.1 & \text { AS CRIAÇÕES E SEUS NOVOS IDEALISTAS } & 15\end{array}$

1.2 A ZONA CINZENTA DAS STARTUPS 20

1.3 EXPERIÊNCIA NO DEMO DAY 22

1.4 O QUÊ DAS QUESTÕES 25

2 AS REDES 26

2.1 HISTÓRICO CONCEITUAL 28

$\begin{array}{ll}2.2 & \text { SOCIABILIDADE } \\ 2.3 & 34\end{array}$

2.3 HABITAR $\quad 41$

3 CARACTERIZAÇÃO DAS STARTUPS

3.1 A ASCENSÃO

3.2 O ECOSSISTEMA

3.3 O CICLO 60

4 AS STARTUPS: FENÔMENO DA IMATERIALIDADE 64

4.1 PROTAGONISMO COGNITIVO

4.2 MÁQUINA PRODUTIVA 76

4.3 CONHECIMENTO EM ESCALA $\quad 85$

5 PESQUISANDO NA ZONA CINZENTA

5.1 COMPLEXIDADE E INCERTEZAS 93

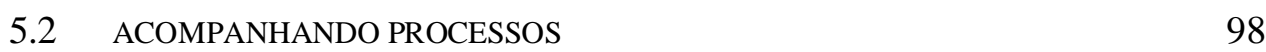

5.3 ANÁLISE E PRODUÇÃO DE CONCEITOS 103

6 A ZONA CINZENTA 107

$\begin{array}{lll}6.1 & \text { INÍCIO E TRAÇÃO } & 111\end{array}$

$\begin{array}{lll}6.2 & \text { MUDANÇA E PARAGENS } & 113\end{array}$

6.3 ABISMO E DESCOBERTA 114

7 PONTO DE IDEAÇÃOO

$\begin{array}{lll}7.1 & \text { AFETAÇÃO } & 116\end{array}$

$\begin{array}{lll}7.2 & \text { ENCONTROS } & 121\end{array}$

$\begin{array}{lll}7.3 & \text { CONCEITUALIZAÇÃOO } & 125\end{array}$

8 PONTO DE EXPERIMENTAÇÃOO 130

8.1 PRODUÇÃO DE REDES 131

8.2 COCRIAÇÃO 133

$\begin{array}{ll}8.3 \text { OBJETIVAÇÃO } & 142\end{array}$

9 (IN)CONCLUSÕES 148

9.1 O CONHECIMENTO COMO FORÇA PRODUTIVA $\quad 150$

9.2 A NATUREZA COMUNICATIVA DAS STARTUPS DIGITAIS 151

9.3 A COOPERAÇÃO COMO ‘ASAS’ DA CRIAÇÃO 153

10 REFERÊNCIAS BIBLIOGRÁFICAS

$\begin{array}{ll}11 & \text { APÊNDICES } \\ \text { APÊNDICE A - ENTREVISTA I } & 170\end{array}$

APÊNDICE B - ENTREVISTA II 178

APÊNDICE C - ENTREVISTA III 182

APÊNDICE D - ENTREVISTA IV 193

APÊNDICE E - ENTREVISTA V 200

APÊNDICE F - ENTREVISTA VI 205

APÊNDICE G - ENTREVISTA VII 208

APÊNDICE H- QUESTIONÁRIO INICIAL PARA ENTREVISTA INTENSIVA 212 


\section{INTRODUÇÃO}

Nos últimos anos acompanhamos o advento e a explosão das tecnologias digitais, alicerçadas na comunicação e informação, e conectadas em redes. Com alta capacidade de apropriação, disseminação e inovação, as novas tecnologias produzem uma intensa participação nas mais diversas atividades humanas no contexto contemporâneo. Tecnologias como espaços wireless (sem fios), big data (megadados), dispositivos móveis, cloud computing (computação em nuvem) e internet of things (internet das coisas) vêm sendo introduzidas em escala crescente nas indústrias, nos mercados e no cotidiano das pessoas.

O novo potencial tecnológico produz um complexo ecossistema comunicativo responsável por modificar a arquitetura da comunicação e, em um sentido mais amplo, modificar a própria arquitetura do social na contemporaneidade (DI FELICE, 2008; SANTAELLA, 2003). Distante de obedecer a uma lógica unidirecional, hoje as informações se apresentam em fluxos, estabelecendo uma comunicação dialógica e ampliando de maneira inédita os processos de participação coletiva. Esse contexto extraordinário permite que as pessoas interajam economicamente umas com as outras e se conectem na criação de novas relações sociais de produção, de novos arranjos econômicos e de cooperação.

Dentro de uma economia profundamente impactada pela presença de uma arquitetura informativa, descentralizada e cognitiva, as relações e trocas sociais ganham uma importância inédita como um fenômeno econômico. As saídas da competência de produção e da capacidade de inovação para espaços fora das grandes estruturas, bem como a desterritorialização dos espaços de produção, dão escala aos processos cooperativos, que despontam como um dispositivo fundamental de criação no âmbito das economias descentralizadas.

No cerne destas mudanças rápidas, estruturais e desestabilizantes ocorridas no interior da economia contemporânea, observamos a emergência de um tipo de empreendedorismo plural e instantâneo: o das startups digitais. Ele é marcado pela intensa participação das tecnologias digitais em seus potenciais produtivos (escalabilidade) e comunicativos (ações em ecossistemas), bem como pelas transformações qualitativas, estreitamente relacionadas com a cultura cooperativa e com o paradigma de uma arquitetura social em rede.

O contexto de emergência das startups digitais provém de uma intensa produção de atividades que possuem como conteúdo central a comunicação, o conhecimento, o saber e a cooperação social na produção de um trabalho que é, sobretudo, intelectual. Uma inteligência encontrada na base da inovação, da comunicação e da auto-organização criativa que funciona como força produtiva incomensurável em circulação e conexões em rede. Tal protagonismo 
cognitivo é o ponto de partida para a noção de uma economia do conhecimento (GORZ, 2005), que destaca em sua abordagem a dimensão imaterial da estrutura econômica contemporânea.

Estes novos corpos no mercado resultam de um complexo processo comunicativo e de relações de interdependência entre as arquiteturas comunicativas, as informações, as pessoas, os objetos inteligentes, os dispositivos móveis e os espaços infocomunicativos. Imersa em uma ecologia de redes, a prática do empreendedorismo, até então circunscrita entre paredes, parece ganhar novas dimensões, deslocando-se para outros espaços, incorporando novos agentes, novas inteligências, nova engenharia e uma nova cultura. Assume, assim, uma complexidade outra ao emergir de uma espacialidade e de uma dinâmica diversa, produzindo, portanto, uma espécie de prática que nos parece escapar do modo tradicional de empreender.

Tratam-se de iniciativas que parecem não mais apresentar uma lógica sistêmica ou obedecer aos modelos tradicionais de semiexternalidades, mas que se realizam em uma lógica de rede de redes. Apresentam uma dinâmica complexa relacional, que provoca-nos a pensar este tipo de empreendedorismo muito mais como um agenciamento permanente de atores em rede, relações sociais e circuitos comunicacionais.

Nesta perspectiva, a pesquisa indagou como de fato ocorre o fenômeno das startups, nas coisas mesmas das suas idealizações, criações, mimeses, e produziu um intenso tecimento sobre a criação das startups digitais em estágio embrionário. Teve como foco as ações de seres-redes que denominamos Novos Idealistas, num percurso de alta criticidade denominado, Zona Cinzenta - um território fluido, passageiro e dramático, no qual efetivamente ocorre a realização (ou não) da startup.

A pesquisa abdicou de ficar presa a um corpus e se propôs a seguir movimentos, produzindo relatos de uma interação com os empreendedores startup e seus empreendimentos em ecossistema de criação, forjando seus territórios de poder-fazer. Assim, o trabalho realizou um acompanhamento de processos nesses territórios moventes, desenvolvendo uma cartografia de conceitos que pulsam com intensidade em torno do objeto. Já a análise foi produzida por meio do desenvolvimento de conceitos, Grounded Theory, capturados dos próprios dados produzidos pelas informações observáveis, entrevistas intensivas, vivência com as startups e moradas em suas arquiteturas comunicativas em rede.

Ao produzir relatos densos do praticismo high-tech destes seres-redes no mundo do empreendimento, a pesquisa também produziu caminhos para pensarmos o fenômeno das startups digitais ao problematizar sua inserção enquanto máquina de produzir e produzir-se, tendo o conhecimento como o "corpo" das realizações. 


\section{AS STARTUPS DIGITAIS}

Um fenômeno novo se enuncia na nova arquitetura da sociedade-rede, como expressão do auto-empreendedorismo demarcado por uma 'ideologia' do trabalho como um permanente produzir-se. Nas startups, este fenômeno é por vezes percebido como uma "ruptura", mas também como um "rearrumamento" - um novo operandi. De fato, trata-se de transformação e comunicação por meio de novos protagonistas em ação no que tradicionalmente chamamos de "mercado", que se expressa, na verdade, como a própria vida feita business. Com efeito, as startups são fenômenos da hegemonização do trabalho com o protagonismo humano-máquina, da vida em permanentes êxodos e misturas, traduzindo um modo de produzir por meio de agenciamentos coletivos em rede (DELEUZE; GUATARRI, 1997)

Imersas em um novo paradigma tecnológico, marcado por um tipo de tecnologia com alta capacidade de apropriação, disseminação e descoberta de novas aplicações (CASTELLS, 1999), e de extremo potencial produtivo e distribuído (RIFKIN, 2012, 2016), estas ações empreendedoras, em grande medida, dedicam-se à criação de novos mercados potenciais ou à transformação de experiências daqueles já existentes e/ou tradicionais. Esta pesquisa produz um intenso tecimento sobre a criação das startups, tendo em foco as ações dos seus sujeitoscriadores, que denominamos Novos Idealistas. Não é fácil realizar o tecimento dessas ações, se desejássemos produzir universalizações.

Ao mesmo tempo, também não é simples, definir os Novos Idealistas como se fossem novos descobridores. Tanto o objeto quanto o sujeito são seres líquidos (BAUMAN, 2007). Os tecimentos ocorrem sobre retículas em diferentes tons, em todas as dimensões da economia e da vida tendo o conhecimento como principal força produtiva. Quem produz este tecido são seres que vem de outras paragens e não se fixam em um só território. A pesquisa os percebe como seres híbridos com alta escolaridade e desprendimento.

Do ponto de vista pessoal, destacam-se como seres apaixonados por uma causa, sem senso de hierarquia, mobilizados para ação por meio de autorias coletivas, em protagonismo com um mundo da multiplicidade, das conexões, de permanentes agenciamentos ${ }^{1}$. As startups são produzidas com o "emblema” destes que chamamos Novos Idealistas. O "território" sobre o qual as startups se desenvolvem transcorre, na verdade, dentro da arquitetura-rede da

\footnotetext{
${ }^{1}$ Estudo realizado pelo SEBRAE-SP sobre o ecossistema de startup: Pesquisa Lado A, Lado B - Startup, realizada com empreendedores de startups e investidores/apoiadores entre setembro e novembro de 2015, perfilou os empreendedores de startup no estado de São Paulo. Disponível em: http://www.sebraesp.com.br/arquivos_site/biblioteca/EstudosPesquisas/estudos_tematicos/lado_A_B_startups.pd f. Acesso em: 01 jun. 2016.
} 
sociedade da imaterialidade, do fluxo, do click - no qual o grande elemento da sua ativação é a cooperação. A cooperação é na verdade a 'máquina' impulsora da produção imaterial como podemos antever nos cases a seguir sobre a criação e fluxos de produção dos Novos Idealistas.

Eles próprios em pessoa-rede são seu principal capital. Carregam consigo vivências, conhecimentos adquiridos na academia e saberes que circulam nos espaços físicos e online nos quais estas práticas se produzem. Não raramente, os novos idealistas têm alta capacidade técnica e acadêmica em suas formações. Alguns possuem experiências acumuladas no empreendedorismo tradicional das grandes empresas, mas não ficam presos a elas como alternativas de vida e carreira - como podemos ver nos cases a seguir.

\subsection{AS CRIAÇÕES E SEUS NOVOS IDEALISTAS}

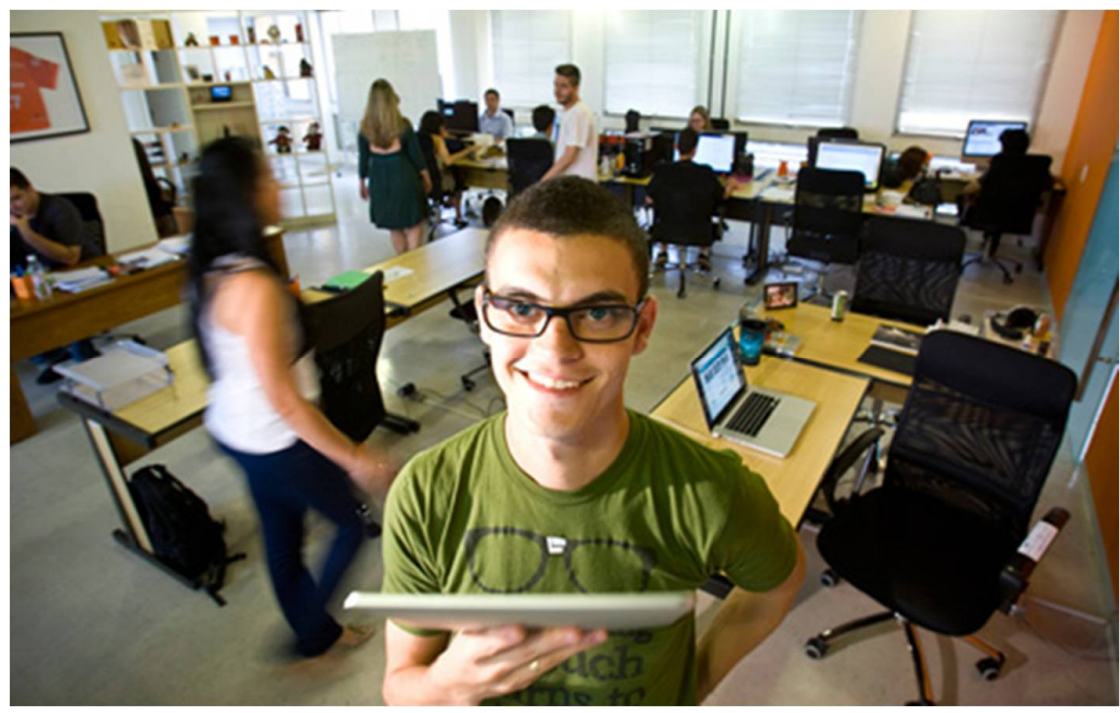

FIGURA 1. BOO-BOX: IMPULSÃO DE VENDAS POR CLICK ${ }^{2}$

Marcos Gomes. Jovem deixa a periferia de Brasília para empreender em são Paulo. Fundador do Boo-box. Premiado como o melhor profissional de tecnologias de marketing do mundo pela World Technology Network em 2013

\section{- Boo-box: impulsão de vendas por click}

A boo-box é uma empresa de tecnologia de publicidade e mídias sociais criada pelo programador e blogueiro brasileiro Marcos Gomes, aos 20 anos. Marcos juntou suas experiências como blogueiro e de trabalho em uma grande agência de publicidade para criar, inicialmente, um produto que permitisse o uso dos blogues independentes para fazer publicidade de verdade e não somente links patrocinados. Isso ajudaria ele e seus amigos a ganharem dinheiro com os conteúdos que estavam publicando. Com a

\footnotetext{
${ }^{2}$ Imagem extraída do blog Social Good Brasil. Disponível em: http://socialgoodbrasil.org.br/2013/qual-o-papelda-juventude-no-desenvolvimento-economia-criativa-ecosoc2013. Acesso em: 10 jun. 2016.
} 
ajuda dos colegas, o programador colocou o protótipo no ar em 2007, um site prélançamento que consistia em uma página de demonstração do produto e um "deixe seu e-mail para saber mais". Dias depois a ideia chamou a atenção do TechCrunch, website americano especializado em tecnologia, que fez uma publicação sobre a ideia. Isto atraiu muitos investidores e parceiros interessados na boo-box. Um projeto que surgiu antes mesmo de ser uma empresa com uma cobertura muito grande da mídia.

A partir daí, nos dezoitos meses subsequentes, Marcos e sua equipe foram batendo na porta de clientes e alterando modelos de negócios até encontrar o encaixe produto-mercado. "Demorou dezoito meses para a empresa ter os seus primeiros clientes" ", relembra Marcos. A boo box atingiu o Break Even, ponto de equilíbrio, em 2010, divulgou um faturamento de 11 milhões em 2014, com uma rede de publicidade com alcance de mais de 65 milhões de pessoas por mês no Brasil e com anúncios de clientes como Google, Unilever, Fiat e Microsoft. Considerada uma das cinco empresas de publicidade mais inovadoras do mundo pelas Revistas Fast Company e Forbes. Recebeu investimentos da Monashees Capital e Intel Capital.

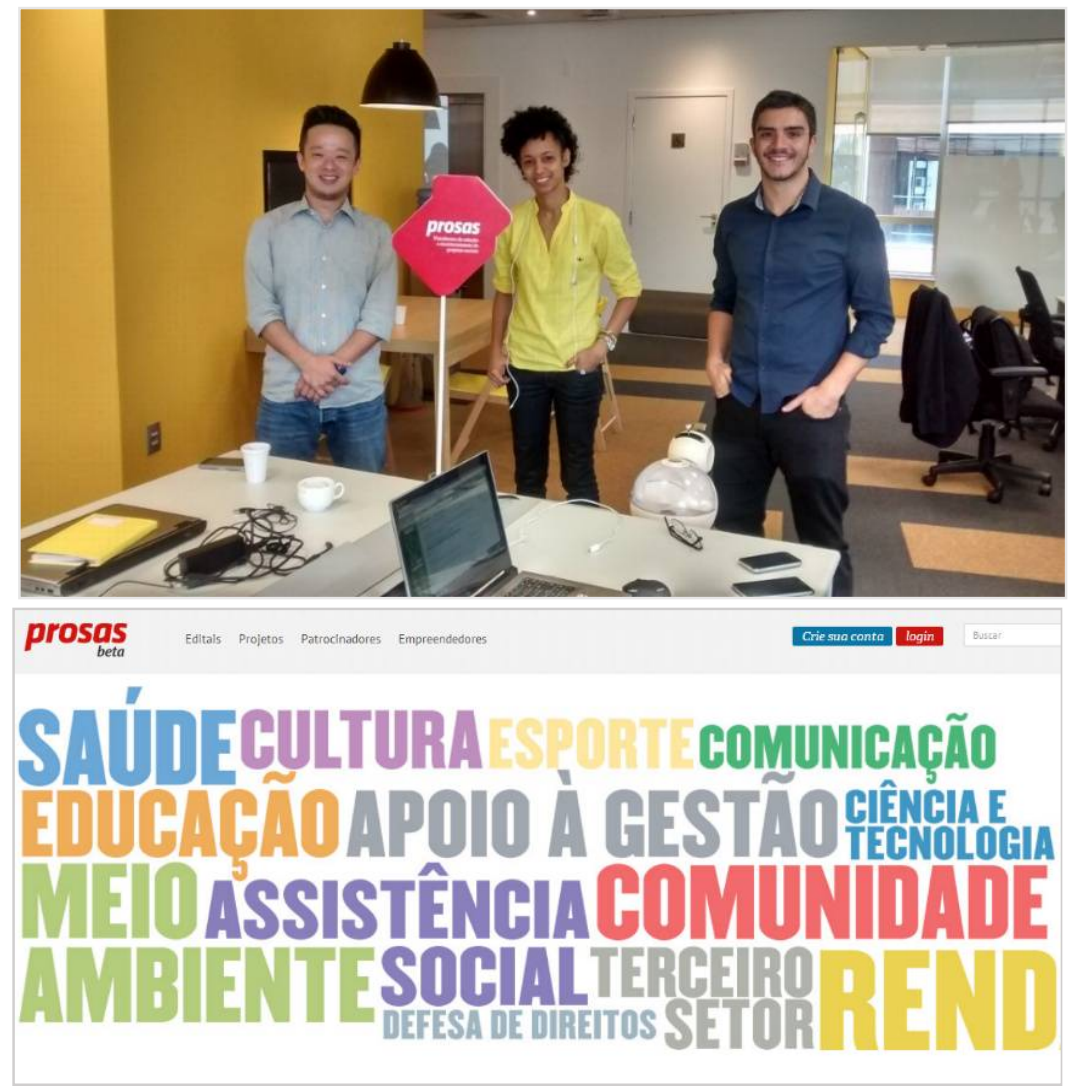

FIGURA 2. PROSAS: CONEXÃO NO TERCEIRO SETOR

Com Ricardo Kaudoaki, gerente comercial e Bruno Barroso, um dos criadores da plataforma que objetiva oferecer profissionalização e transparência para o terceiro setor ${ }^{4}$.

\footnotetext{
${ }^{3}$ Entrevista concedida por Marcos Gomes para Man in Arena, videocast sobre empreendedorismo e cultura digital. Entrevistadores: Leo Kuba, Miguel Cavalcanti. Disponível em https://www.youtube.com/watch?v=OjgJJiBeOu4. Acesso em 01.abr. 2016

${ }^{4}$ A imagem corresponde a foto de arquivo pessoal realizada durante visitação ao Espaço Cubo Co-working, associação sem fins lucrativos de fomento ao empreendedorismo de tecnologia na cidade de São Paulo. Trata-se de uma iniciativa do Banco Itaú Unibanco que conta com os apoios de RedPoint, e.ventures - com a parceria da
} 
- Prosas: conexão no terceiro setor

A plataforma Prosas é um projeto beta que está no ar desde junho de 2015 testando o seu modelo através do mínimo produto viável. Criada por Bruno e Thiago, o Prosas é uma plataforma que visa atender a demanda necessária e urgente das organizações não governamentais - ONGs - que é a profissionalização e transparência de suas atividades. Para isso, o Prosas conecta os atores da cadeia de valor de investimento social como ONGs, voluntários, investidores, doadores e cidadãos em uma plataforma que seleciona e monitora projetos sociais. Para fortalecer o investimento social, o Prosas trabalha em três frentes, permitindo: (i) que patrocinadores selecionem e acompanhem o andamento dos projetos sociais online; (ii) a construção de uma rede que faculta ao empreendedor social encontrar patrocínio para seus projetos, minimizando as dificuldades de encontrar patrocinador e disputar os recursos que são escassos; (iii) o cidadão recomendar e acompanhar os projetos sociais de reconhecida relevância.

Pouco tempo após o lançamento, em janeiro de 2016, a plataforma já apresentava aproximadamente 2.300 cidadãos, 600 ONGs, e mais de 600 editais cadastrados. Para monetizar, a plataforma oferece diversos planos (básico, intermediário, avançado, mensal, anual, por edital). Ao lançarem um edital na plataforma, as empresas pagam por isso. Entretanto, a principal fonte de renda vem das ONGs. O Prosas trabalha com o modelo Freemium que é o free mais premium. Assim, todos os serviços essenciais da plataforma são gratuitos, como a possibilidade da ONG buscar e se inscrever em editais, elaborar e divulgar seus portfólios. São quatro os processos de seleção e acompanhamento que rodaram na plataforma: Instituto Sabin, SulAmerica, um projeto apoiado pela Ambev e um projeto apoiado pela Gerdau.
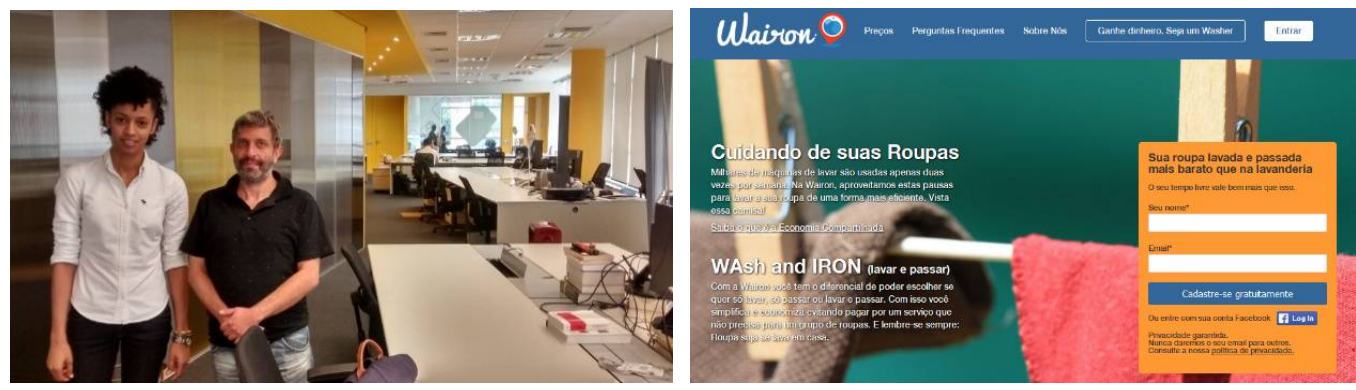

FIGURA 3. WAIRON: COMPARTILHANDO ATIVOS EM REDE ${ }^{5}$

Com João Abussamro no espaço cubo co-working. A plataforma compatilhada cria oportunidade de renda para lavadores e comodidade para quem precisa de cuidados com suas roupas.

Accenture Digital, Ambev e Cisco. E o print screen da plataforma online da startup Prosas elaborado pela autora. Disponível em: https://prosas.com.br/. Acesso em 01 jun. 2016.

${ }^{5}$ A imagem da esquerda corresponde à foto de arquivo pessoal obtida durante visitação ao Espaço Cubo Coworking, associação sem fins lucrativos de fomento ao empreendedorismo de tecnologia na cidade de São Paulo. Trata-se de uma iniciativa do Banco Itaú Unibanco que conta com os apoios de RedPoint, e.ventures com a parceria da Accenture digital, Ambev e Cisco. A imagem da direita é o print screen da plataforma online da startup Wairon, feito pela autora. Disponível em: https://wairon.com/. Acesso em 01 jun. 2016 


\section{- Wairon: compartilhando ativos em rede}

Após experiência de dezoito anos na área de TI o empreendedor João Abussamro, sócio-fundador e CEO da Wairon, define-se como "um empreendedor de cabelos brancos". A sua empresa anterior criou um software de comércio exterior pioneiro no Brasil. Uma longa experiência empreendedora que ele refereao modelo antigo, tradicional. Segundo Abussamro, ele agora está vivendo uma outra experiência dentro do empreendedorismo. Acostumado a um ambiente de contrapartidas, ele conta com surpresa a primeira quebra que teve quando, em um café com o fundador de uma startup brasileira de compartilhamento de carros, este desenhou o seu modelo de negócio para colaborar com a fase de ideação do projeto Wairon. Segundo ele, o ambiente é mais colaborativo.

A ideia do Wairon, que nasce da iniciativa de Abussamro e de seu sócio Omar, tem sua modelagem baseada na economia compartilhada. Trata-se de uma plataforma de intermediação que conecta usuários a prestadores de serviços de lavanderia. Nela os pedidos dos usuários são direcionados automaticamente para um washer - nome dado a lavadeira parceira capacitada para fazer os serviços de lavagem e passagem por conta própria e com o uso de sua própria máquina de lavar. O serviço tem seu gerenciamento totalmente online, com os pagamentos realizados dentro da própria plataforma. A monetização ocorre por meio de divisão de receitas: uma vez deduzido o serviço de logística, que sofre variações em função da distância, destinam-se $60 \%$ do valor pago para o washer e $40 \%$ ficam com a startup. Em fase de experimentação a Wairon conta com quarenta washers e testa o serviço trabalhando com motoristas terceirizados para realizar o trabalho de transporte e logística. A concepção deu-se em janeiro de 2015 e a ideia entrou em produção em janeiro de 2016. A Wairon é acelerada pela HAG Consulting, de Curitiba.
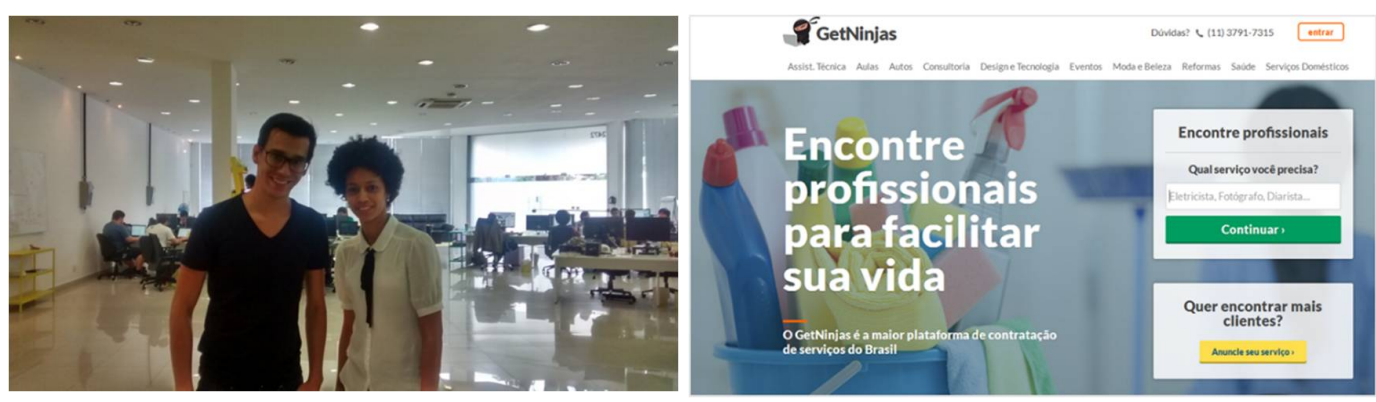

FIGURA 4. GETNINJAS: MARKETPLACE HORIZONTAL DE SERVIÇOS ${ }^{6}$ Com L'Hotellier, fundador do GetNinjas no escritório em São Paulo. A plataforma de intermediação de autônomos já reúne mais de 100 mil profissionais, coleciona premiações como melhor startup brasileira e latinoamericana pela Microsoft, The Next Web e Fnbox.

\footnotetext{
${ }^{6}$ A imagem corresponde a foto de arquivo pessoal realizada durante visitação ao Espaço Cubo Co-working, associação sem fins lucrativos de fomento ao empreendedorismo de tecnologia na cidade de São Paulo. Trata-se de uma iniciativa do Banco Itaú Unibanco que conta com os apoios de RedPoint, e.ventures com a parceria da Accenture digital, Ambev e Cisco. E o print screen da plataforma online da startup GetNinjas feito pela autora. Disponível em: https://www.getninjas.com.br/. Acesso em 01 jun. 2016.
} 


\section{- Getninjas: Marketplace horizontal de serviços}

Setecentos dólares - na época cerca de 1.500 reais - foi o investimento de Eduardo L'Hotellier para comprar uma plataforma pré-pronta na Índia, que, com algumas alterações no design do produto, lhe serviria como protótipo para testar a ideia do seu negócio. Não muito feliz com o seu trabalho e interessado em aprender a empreender, Eduardo viu no site indiano a possibilidade de testar a sua ideia de forma rápida e com poucos recursos, conciliando a nova atividade com o seu trabalho. A plataforma lançada em outubro de 2010 estava um pouco aquém do efervescente cenário para as startups brasileiras, mas Eduardo contata com seu know-how - naquele tempo trabalhava em uma grande empresa de investimento, e com formações em engenharia da computação e formação incompleta em administração. Ao vivenciar uma difícil experiência para contratar um serviç̧o de pintor, ele percebeu que, na época, não existia uma ferramenta clara de contratação de serviços online, sendo necessário recorrer aos serviços de classificados e às páginas amarelas. Sem fazer muitas contas e com recursos próprios, Eduardo reuniu o desejo de empreender e a identificação da oportunidade, e lançou a plataforma com o nome de Cidade dos Bicos.

O lançamento do protótipo atraiu mídia espontânea. Em menos de um ano um fundo se interessou pela iniciativa e contatou Eduardo pelo Linked In, sendo que hoje dedica-se exclusivamente à startup. A empresa foi constituída de fato em abril de 2011 e está na sua terceira rodada de investimento. A primeira, de $\mathrm{R} \$ 1$ milhão, ocorreu em 2011, na abertura do negócio. Em 2013 houve a segunda rodada no valor de R\$ 6 milhões. Em 2015, a startup recebeu o aporte de R $\$ 40$ milhões. A plataforma começou como um marketplace de serviços online e hoje é um marketplace de serviços off-line, que permite ao usuário a contratação de serviços locais divididos em 150 categorias como reformas, limpeza, assistência técnica, fotografia e aulas particulares. A missão de conectar pessoas a profissionais continua a mesma. A GetNinjas vende para o profissional a oportunidade de negócio e não a transação em si. Para monetizar, a startup cobra do profissional, que paga por conexão, uma assinatura para receber 30 clientes por mês.

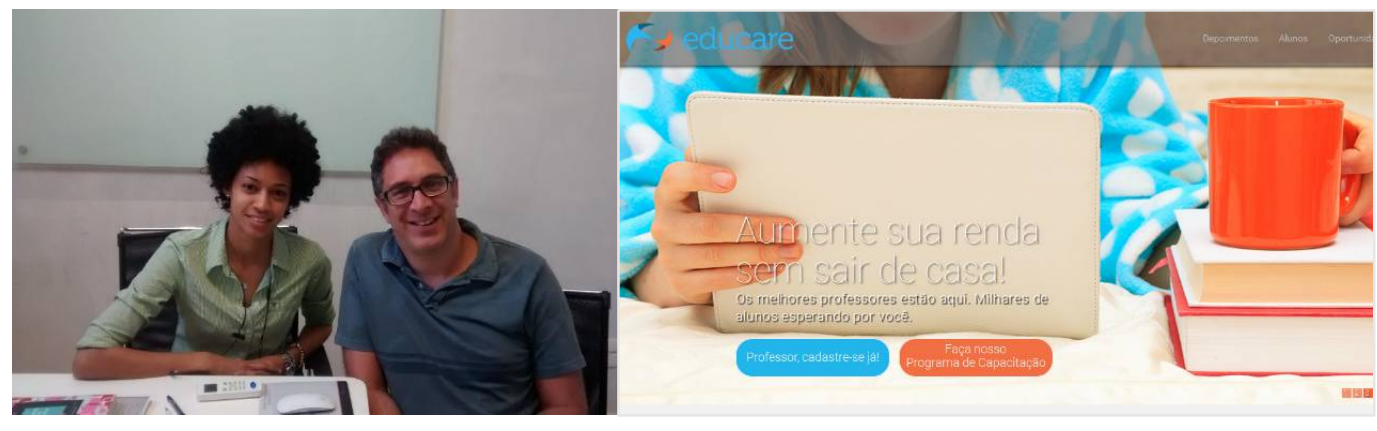

FIGURA 5. EDUCARE: TECNOLOGIA E EDUCAÇÃO

Com Márcio Boruchowski, fundador da startup de educação Educare, um ambiente de ensino a distância individualizado, que atende demandas pontuais de alunos, especialmente do ensino fundamental e médio. ${ }^{7}$

${ }^{7}$ A imagem corresponde à foto de arquivo pessoal realizada durante visitação ao Espaço Cubo Co-working, associação sem fins lucrativos de fomento ao empreendedorismo de tecnologia na cidade de São Paulo. Trata-se de uma iniciativa do Banco Itaú Unibanco que conta com os apoios de RedPoint, e.ventures com a parceria da Accenture digital , Ambev e Cisco. E o print screen da plataforma online da startup Educare feito pela autora. Disponível em: https://educarebr.com.br/ . Acesso em 01 jun. 2016 


\section{- Educare: aulas particulares e tutoria online}

Boruchowski (2015) nos revela que buscou empreender por um misto de oportunidade e desejo. Oportunidade, porque tinha dinheiro em caixa, e desejo, porque queria sair do ambiente corporativo. No momento da realização de nossa entrevista, em novembro de 2015, a startup de educação que oferece aulas individuais ao vivo, tinha apenas cinco meses de operação. Para o empreendedor, a escolha pela Educação revela o seu desejo em trabalhar com negócios de impacto. A educação oferece grande potencial de sofrer uma transformação por vias tecnológicas e "o maior benefício desta tecnologia da educação é a personalização e a redução de custos”, nos diz o empreendedor.

Na plataforma Educare é oferecido o ensino em todas as disciplinas de ensino fundamental e médio, além do oferecimento de algumas disciplinas de ensino superior. $\mathrm{O}$ aluno escolhe um plano de aula mensal, podendo acessar professores treinados e avaliados, 24 horas por dia. Lá, o aluno pode registrar a sua demanda pontual, com detalhamento de suas dúvidas e inclusão de documentos, apresentações de aula e fotos da lousa ou caderno. As aulas ocorrem em um ambiente de ensino a distância individualizado, com imagens, áudio e chat. Os processos de conexão da demanda do aluno com a oferta de professores é completamente automatizado. No ambiente virtual de aprendizagem, o algoritmo resolve questões e aceita o transporte de informações, recursos, ferramentas e inteligências da rede para o ambiente de ensino. Explica Boruchowski (2015), enfatizando os processos de autoria e as conexões que se produzem nas ações. A Educare, como uma escola digitalizada, ocupa-se da gestão de uma cadeia de competências e de dados, e não de uma estrutura física, de uma cadeia de valor e do trabalho material, realizando as suas atividades por meio da manipulação de dados e pela reunião e coordenação de inteligências.

\subsection{A ZONA CINZENTA DAS STARTUPS}

O praxismo das startups encontra profunda conexão com a teoria do imaterial. Para Negri (2003), vivemos uma forma de existência e em um mundo produtivo que se caracterizam pela hegemonia do trabalho intelectual. Trata-se de uma época cognitiva em que a produção depende cada vez mais de uma atividade intelectual criadora que nasce dos sujeitos e se organiza na cooperação e do trabalho linguístico.

Assim, sem experiências precedentes, sem projeções assertivas, sem modelagens prédefinidas, as criações startup percorrem caminhos incertos, imprevisíveis, não lineares. Como de fato ocorre o fenômeno das startups, nas coisas mesmas das suas idealizações, criações, mimeses? Ao mergulhar nas águas turvas deste fenômeno, percebemos o 'quê' da coisa que emerge em um território fluido, passageiro e dramático, no qual efetivamente ocorre a realização (ou não!) da startup. Trata-se de uma passagem, um tempo, um transcurso, que esta pesquisa nomina como Zona Cinzenta, o abismo entre a ideia e a execução em que os novos idealistas experenciam a criticidade do alto grau de incerteza na criação das suas startups. 
São nas "trilhas" sinuosas da Zona Cinzenta que a pesquisa se detém, investigando o fenômeno das startups justamente na sua fase mais turbulenta de realização. Naturalmente, não há nenhuma 'calmaria' no ato de ser-startup, de produzir ao produzir-se. A Zona Cinzenta, no entanto, diz a passagem, enuncia a coisa que está por vir. Nela o ser se objetiva. A coisa ganha forma ou muda sua própria forma. Com este percurso, a pesquisa também produz caminhos para pensarmos o fenômeno das startups ao problematizar sua inserção enquanto máquina de produzir e produzir-se, tendo o conhecimento como o "corpo" das realizações.

Ao trilharmos o trânsito das startups em seu early stage (estágio inicial), encontramos uma fértil oportunidade para pensarmos esta emergência em uma dimensão acentrada e de muitas lógicas, que ultrapasse os limites categóricos e disciplinares do estudo do empreendedorismo e nos permita cumprir a exigência de um aprofundamento conceitual e reflexivo, sem o qual compreendemos que esse fenômeno encontraria profundas limitações para ser explicado.

Sem dúvidas, tal contexto provoca-nos para buscar novas teorias capazes de explicar a emergência deste tipo de empreendedorismo. As startups não se apresentam em uma lógica sistêmica ou obedecem aos modelos tradicionais de semi-externalidades, mas se realizam em uma lógica de redes de redes, cujas relações e fluxos se estabelecem em interações múltiplas, expressas em uma ausência de totalidade e linearidade.

Muito mais que analisar uma relação de causa e efeito, a compreensão dessa nova modalidade contemporânea de empreender nos exige um olhar para além da instrumentalidade tecnológica e os efeitos desta tecnologia na reestruturação das relações de produção, recursos materiais e humanos. Seu estudo nos provoca a expandir nossa dimensão de análise a fim de compreendermos esse coletivo organizado em rede com grande potencial para (re)organizar os modos de empreender contemporâneo e construir um novo social tecnológico e cooperativo.

A pesquisa situa esta zona como o percurso-eureca da sua produção, momento da fertilização e, ao mesmo tempo, dos seus mais profundos paradoxos. A pesquisa adentra nos processos de construção das startups, enunciando processos de subjetivações produzidos pelos seus sujeitos idealizantes, realizando conceitos sobre seus tecimentos a partir desta passagem. O corpo que realiza este fenômeno não tem órgãos pré-definidos, uma vez que as startups se propagam como máquinas de uma nova arquitetura-rede, ultrapassando relações hegemonizadas pelo presencial, local, territorial, impulsionando o empreendedorismo a partir de ecossistemas comunicativos cuja marca permanente é a descentralização dos processos.

O que está em emergência não é um desafio ao status-quo, como se diz, mas um novo tecimento de algo que se enuncia com uma aparência sem uma face definida para ser retratada. 
E isto se observa por meio dos circuitos comunicacionais, relações sociais e a produção mesma da coisa-startup cuja definição resiste em ser enquadrada num conceito-acabado.

Embora "filhas" de criadores-criaturas, as startups surgem não de um querer individual, individualizado, mas das necessidades sociais que estão a demandar novas formas, novos atos, certas reconfigurações - como se vê nos seus processos de realização e nos próprios acontecimentos produzidos pelos Novos Idealistas e/ou agentes promotores deste fenômeno como a que se relata no chamado Demo Day.

\subsection{EXPERIÊNCIA NO DEMO DAY}

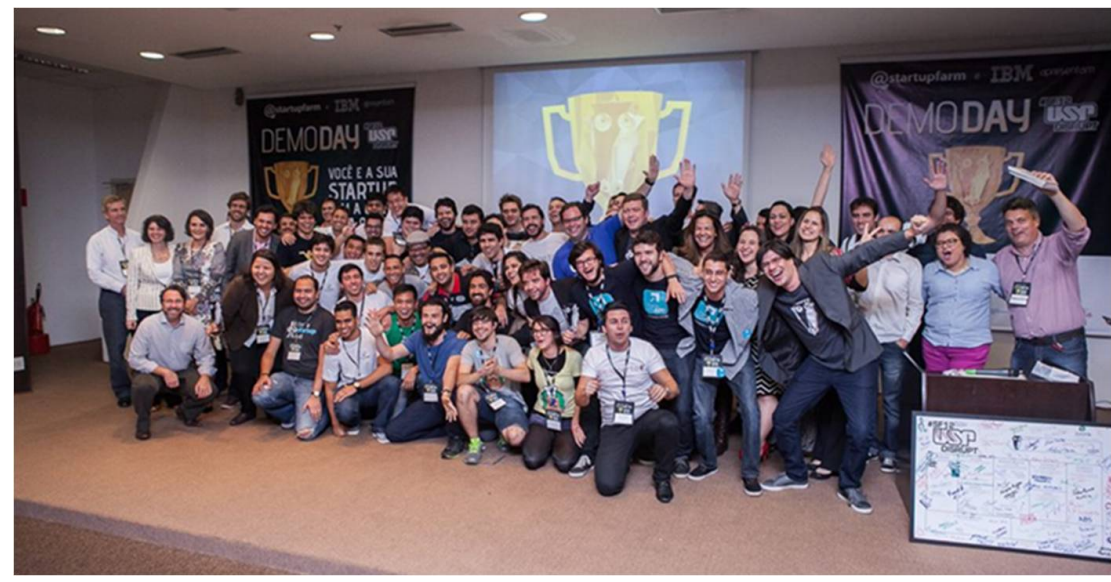

Figura 6. DEMO DAY

Novos idealistas e agentes promotores do fenômeno startup participam do $12^{\mathrm{a}}$ edição do Demo Day da aceleradora Startup Farm, realizado na Cidade de São Paulo ${ }^{8}$

O auditório composto por uma plateia de investidores, representantes de grandes corporações, estudantes, especialistas em tecnologia, mercadólogos, empreendedores, educadores, outsiders e early adopters ${ }^{9}$. A atmosfera de celebração somava à perceptível ansiedade daqueles que experenciam sem muita familiaridade o palco, o microfone e o desafio de, em não mais que dez minutos, apresentar, usando uma cultura high-tech, um modelo de negócio viável para uma bancada também formada por investidores e especialistas de mercado e tecnologia.

${ }^{8}$ Foto publicada na fanpage da Startup Farm. Disponível em: https://www.facebook.com/startupfarm/photos/a.443572692379980.1073741825.144942248909694/105764774 0972469/?type=3. Acesso em: 02 jun. 2016.

${ }^{9}$ Early adopters refere-se ao público alinhado com a visão do negócio e mais predisposto a consumir e avaliar produtos inovadores. Este público muitas vezes compreende formadores de opinião e entusiastas por tecnologia e novidades no mercado. Para as startups, eles costumam representar o público-alvo inicial de qualquer produto ou serviço, antes que esse venha a sofrer as modificações necessárias para divulgação ao grande público. 
Trata-se da fase final de um dos muitos programas de aceleração ${ }^{10}$ de startups de tecnologia digital que proliferam nas grandes capitais do mundo e que a cidade de São Paulo vem experenciando nos últimos anos. Este momento é conhecido como “Demo Day”. Trata-se de um primeiro momento em que as iniciativas de inovação são oficialmente apresentadas ao mercado. Um acontecimento que pode representar para estas iniciativas a oportunidade de conquistar um aporte inicial que assegure os próximos passos do negócio ainda em construção.

Nessa que foi a $12^{\text {a }}$ Edição do Demo Day da Startup Farm, maior acelerador de startup da América Latina, promovido em parceria com o Centro de Competência em Software Livre do IME - USP e o Núcleo de Empreendedorismo da Universidade de São Paulo (USP), com os apoios da IBM e da IUGU, apresentaram-se nove startups finalistas do programa com diferentes modelos de negócios e de diferentes segmentos - saúde, construção civil, aplicações. Ali, equipes heterogêneas apresentam modelos de negócio diversos, ancorados na exploração dos potenciais comunicativo, produtivo e cooperativo das novas tecnologias digitais, tendo-as como porta de acesso para o exercício da prática do empreendedorismo.

Nas apresentações, a exposição de um conteúdo minuciosamente ajustado em um roteiro ensaiado também é resultante de preparação prévia oferecida pelo próprio programa de aceleração. Trata-se do pitch, modelo de apresentação precisa e ajustável usada para comunicar propostas para clientes ou potenciais investidores. Nada de planilhas, grandes projeções, detalhados estudos prévios de mercado ou um robusto plano de negócio. Em uma processo de imersão de algumas semanas, as equipes elaboraram seus modelos de negócio tendo como referência modelagens como a de Osterwalder e Pigneur (2011), que adotaram a linguagem do design e utilização de ferramentas gráficas, ressaltando o visual como dispositivo de foco, ação, criação e captura de valor.

Como em um processo de experimentação, as equipes apresentam o levantamento de suas hipóteses de produto e modelos de negócios e buscam atrair o investidor e early adopters a interativamente testá-los e validá-los junto com elas, revelando um alinhamento de suas práticas com o processo rápido e flexível de concepção de produtos tecnológicos sugerido pelos princípios de lean startup, elaborados por Eric Ries (2012). A prática do empreendedorismo ${ }^{11}$,

\footnotetext{
${ }^{10}$ Programas de aceleração são programas operados geralmente por empresas aceleradoras que agregam apoio intelectual e/ou financeiro a empreendimentos nascentes.

${ }^{11}$ Embora histórico e milenar, o empreendedorismo não tem uma base teórica que o situe. Ele é abrigado e abriga produções dos mais diferentes campos do conhecimento. Scott Shane, professor e diretor de pesquisa do Centro de Empreendedorismo Dingman na Universidade de Maryland, cujas pesquisas atuais concentra-se no empreendedorismo em contextos de alta tecnologia, oferece contribuições valiosas para a construção de bases epistemológicas do empreendedorismo. Na obra A General Theory of Entrepreneurship: The IndividualOpportunity Nexus, Shane (2004, p.4, tradução nossa) conceitualiza o empreendedorismo como: "uma atividade que envolve a descoberta, avaliação e exploração de oportunidades para introduzir novos produtos e serviços,
} 
até então circunscrita entre paredes, ganha, com as tecnologias digitais, novas dimensões, deslocando-se para outros espaços geográficos e não geográficos, incorporando novos agentes, novas inteligências, novas qualidades, assumindo uma complexidade outra ao emergir de uma espacialidade e uma dinâmica diversa, produzindo, portanto, uma espécie de prática que escapa do modo tradicional de empreender.

Nestas práticas empreendedoras cujo " $D N A$ " é o digital, parece-nos que as tecnologias digitais assumem um tipo de participação que transcende a noção de uso ou instrumentalidade, ou seja, da tecnologia como mero "recurso", "ferramental", "instrumental", "otimizador" de processos. Aqui elas formam um corpo sem órgãos ${ }^{12} \mathrm{com}$ a participação fundamental no pensamento e na concepção dessas iniciativas de inovação, deslocando-se para uma posição de protagonismo, sem a qual estas iniciativas não se realizariam.

Ao articular-se a partir da exploração das competências comunicativas e produtivas dessa novas tecnologias alicerçadas na comunicação e informação, essas iniciativas pareciam produzirem-se por meio de um tecimento coletivo de saberes, inteligências e máquinas em rede, refletindo também as transformações qualitativas, estreitamente relacionadas com uma cultura comunicativa e o paradigma de uma arquitetura social em rede advindos das tecnologias digitais.

Ao emergirem de ecossistemas comunicativos, tais iniciativas também parece-nos apresentar a natureza relacional, cooperativa, de instantaneidade e de conectividade, incorporando características extraídas da própria rede, sendo elas também, redes. Assim, o Demo Day, Aceleradoras, Pitch... nos serviram como 'brechas' de acesso que abririam caminhos na tentativa de entender os contextos e o empreendedorismo startup.

formas de organização, mercados, processos e matérias-primas, através da organização de esforços que antes não tinham existido." Na contramão das literaturas sobre o empreendedorismo, que o fragmenta ao abordar enfaticamente a performance do indivíduo empreendedor ou das empresas no contexto de pequenos ou de novos negócios, Shane (2004) convida os pesquisadores a perceber a relação entre múltiplos fatores que compõem o empreendedorismo. Nesta direção, ao hifenizar no subtítulo da sua obra, indivíduo e oportunidade, Shane abstrai a individualização que separa a presença das oportunidades lucrativas da presença do indivíduos empreendedores e suas ações, alertando-nos para os efeitos que esta separação provoca ao limitar a complexidade que o processo empreendedor guarda em si.

${ }^{12}$ Deleuze e Guatarri trabalham com o conceito de 'corpo sem órgãos' nas obras Mil-Platôs (1995) e O Anti-Édipo (2010), tomado de empréstimo de Antonin Artaud para pensar um corpo não instrumentalizado de pura intensidade. 


\subsection{O QUÊ DAS QUESTÕES}

Nós, baianos, perguntamos qual é de mesmo? quando estamos tentando entender os contextos e desejando nos aproximar de um assunto que nos intriga... Que tipologia de empreendedorismo se desenvolve na chamada Zona Cinzenta como emergência da sociedaderede? Com efeito, a pesquisa investiga as ações de criação das startups no seu estágio inicial e ao mesmo tempo conceitualiza seu fenômeno como máquinas de produção através das quais o conhecimento é sua principal força produtiva, situando-as como novos corpos realizadores de novas formas de ações empreendedoras.

Ao adentrar a Zona Cinzenta, a pesquisa avança no entorno das suas dimensões, justo quando as startups experimentam o ápice da criticidade e incerteza - nos momentos que denominamos ponto de ideação e ponto de experimentação. Com o objetivo de realizar um tecimento das suas ações nessa travessia, a pesquisa desenvolve uma cartografia de conceitos que pulsam com intensidade no transcurso. A partir do conhecimento produzido pelo acompanhamento de processos nesses territórios moventes, percebemos melhor o fenômeno das startups digitais, dentro de uma nova ordenação da sociedade hegemonizada pelas relações humano-máquinas.

Com efeito, pretendemos contribuir com a busca de novas teorias interpretativas capazes de narrar o dinamismo do empreendedorismo startup e explicar as novas interações que são produzidas dentro dessa nova ecologia comunicativa tecnológica, que nos parece apresentar novas dinâmicas por acontecer em uma espacialidade e uma arquitetura informativa outra, portanto, distinta daquela moderna tradicional. Ao responder como de fato ocorre a criação das startups na Zona Cinzenta, a pesquisa oferece relato denso de procedimentos, ações e realizações, expressando esse fenômeno não como uma abrupta ruptura sobre o status quo, mas como um processo de rearrumamento, transformação e comunicação, por meio de novos protagonismos, tendo nos novos idealistas (sujeitos-redes) os motores de uma máquina revolucionária de movimentos de idealizações. 


\section{AS REDES}

“Onde quer que encontremos sistemas vivos - organismos, partes de organismos ou comunidades de organismos - podemos observar que seus componentes estão arranjados à maneira de rede. Sempre que olhamos para a vida, olhamos para redes. (...). O padrão da vida, poderíamos dizer, é um padrão de rede capaz de auto-organização." (CAPRA, 2001, p.77-78)

Extensa e multidisciplinar, a noção de redes está presente nos mais diversos domínios do conhecimento e vem sendo adotada para abordar uma variedade de sistemas, tais como: nas ciências sociais, definindo sistemas de relações como redes sociais e redes de poder; nas ciências biológicas como rede neuronal humana ou redes metabólicas; nas ciências matemáticas, informática e inteligência artificial, definindo modelos de conexão como teoria dos grafos, conexionismo e cálculos sobre rede; nas tecnologias, definindo a estrutura fundamental das telecomunicações, energia e dos transportes; nas ciências econômicas, definindo as relações financeiras e comerciais entre os agentes econômicos, bem como na elaboração de modelos teóricos como 'sociedade em rede' e 'economia em rede'.

Para André Parente (2013), a impressão é de estarmos diante de um novo paradigma estreitamente relacionado a um pensamento das relações que se opõe a um pensamento das essências. Em "Tramas da Rede: novas dimensões filosóficas, estéticas e políticas da comunicação", obra que apresenta a questão das redes sob o prisma de diferentes abordagens e interesses, Parente reflete que embora o conceito de redes permeie e receba contribuições de áreas distintas, é possível identificar um aspecto de compartilhamento entre essas abordagens. Elas compartilham da percepção de que "a rede se tornou uma dimensão indissociavelmente ontológica e prática, de modelização do mundo e da subjetividade.” (PARENTE, 2013, p. 9)

Quanto à aplicação da noção de redes nos mais diferentes contextos, Pierre Musso (2013) reconhece que esta polissemia do termo somada à multitude de metáforas e suas utilizações gera dúvidas quanto à coerência do conceito, condenando a sua própria noção pelo excesso de empregos. Entretanto, em sentido contrário, o uso demasiado da noção acaba também por demonstrar o seu poder e sua complexidade, conclui o filósofo.

Para Fritjot Capra (2001) a rede é o padrão básico de organização da vida. O físico analisa que as ocorrências de descobertas fundamentais na biologia e na abordagem sistêmica produziram aberturas para formas de pensar não reducionistas e não lineares na atividade científica dos últimos anos. São avanços que ofereceram significativas contribuições para o 
desenvolvimento da teoria da complexidade ${ }^{13}$ e para busca por metodologias capazes de lidar com sistemas.

Na obra "O ponto de mutação: A Ciência, a sociedade e a cultura emergente", Capra (2004) demonstra como as revoluções conceituais, ocorridas na física moderna nas primeiras décadas do século XX, provocaram profundas mudanças na visão de mundo. Ele aponta para uma transferência da concepção mecanicista do mundo de René Descartes e Isaac Newton, marcada por um pensamento racional e linear, para uma consciência ecológica decorrente de uma intuição de sistemas não lineares.

O ponto de vista reducionista e mecânico, que foi desenvolvido pela física clássica para descrever a realidade, tornou-se paradigma dominante, sendo adotado como referência nas ciências naturais, sociais e humanas para criação de suas próprias teorias. Acreditava-se que o universo material era a profusão de objetos separados e montados em uma grande máquina. A máquina cósmica era constituída por peças elementares, assim como as máquinas produzidas por seres humanos. Consequentemente, os fenômenos complexos poderiam ser entendidos a partir da redução de seus componentes básicos e da investigação dos organismos através das suas unidades.

No século XX a nova física desenvolveu importantes trabalhos como a teoria especial da relatividade (A. Einstein) e o princípio da incerteza (W. Heisenberg). Estes estudos exigiram profundas mudanças nos conceitos clássicos de espaço, tempo, matéria, objeto, causa e efeito. As novas descobertas produziram contrastes com a concepção mecanicista de mundo, ancorada no pensamento racional analítico, e revelou suas limitações.

Assim, "O universo deixou de ser visto como uma máquina, composta de uma profusão de objetos distintos, para apresentar-se agora como um todo harmonioso e indivisível, uma rede de reações dinâmicas, (...).” (CAPRA, 2004, p. 37). O deslocamento do padrão cartesiano para o padrão das redes deu força para que estudos fossem retomados e ampliados, como o estudo das redes. Nos próximos subtópicos deste capítulo, abordaremos o histórico conceitual de rede, a sociabilidade e o habitar em rede, respectivamente.

${ }^{13} \mathrm{O}$ pensamento complexo e a ideia de pensar o contexto de redes através da complexidade reticular, considerando a abrangência de artefatos tecnológicos e processos de digitalização na comunicação contemporânea, serão abordados no subtópico 5.1 do Capítulo 5 desta pesquisa. 


\subsection{HISTÓRICO CONCEITUAL}

No artigo intitulado "A filosofia da rede", Musso apresenta uma interpretação da genealogia da noção de rede, desenvolvendo um percurso histórico até chegar à formação do conceito. Segundo ele, a ideia de rede já estava presente na mitologia através do imaginário de tecelagem e de labirinto, e na antiguidade através da medicina de Hipócrates em associações metafóricas ao organismo. O termo "rede" era inicialmente usado pelos tecelões e cesteiros no século XII para qualificar a trama de fibras têxteis (à renda), expressando uma relação de externalidade. Foi introduzido como vocábulo na ciência no século XVIII para designar e desenhar o aparelho sanguíneo e as fibras que compõem o corpo humano, revelando uma rede passível de ser observada dentro do corpo.

As observações dos efeitos de rede nas formas da natureza realizadas pela medicina e pela cristolografia (estudo dos cristais) percebem pontes entre o interior e o exterior. A rede observada apenas sobre ou dentro do corpo humano permite ser pensada também em sua relação com o espaço. Assim, apartada do corpo natural, a rede se torna uma técnica autônoma sobre o território. De dada a construída, como o próprio filósofo reconhece, essa genealogia da rede pode ser interpretada como a história de um processo de desmaterialização conduzida, de rede como uma forma observada ou imaginada na natureza enquanto "efeito rede", identificável sobre e dentro do corpo para sua transformação em artefato, ou seja, algo passível de ser construído (MUSSO, 2013, p.20-21).

A formação do conceito moderno de rede é contemporâneo à obra de Claude-Henri de Saint-Simon (1760-1825), ao evidenciar uma estrutura artificial de gestão tanto do espaço como do tempo. Para delimitar o espaço da noção de rede, Musso (2013) ordena as significações em torno do conceito a partir de duas formas gerais: um modo de raciocínio e um modo de organização do espaço-tempo. Este refere-se a uma matriz técnica e à carga simbólica que ela carrega, ou seja, uma concepção que explora a relação entre a rede e o território, adicionado ao espaço-tempo físico um espaço ampliado e um tempo reduzido. Aquele refere-se a um conceito e a uma tecnologia do espírito. Tomando como empréstimo as contribuições de Michael Serres (que percebe a rede contra uma racionalidade linear); Henri Atlan (um intermediário entre a incerteza do caos e a racionalidade formalizada) e Anne Cauquelin (um produtor de passagem, mediação e ligação), Musso se propõe a definir a rede como "uma estrutura de interconexão instável, composta de elementos em interação, e cuja variabilidade obedece a alguma regra de funcionamento". (Ibidem, p. 31-32). Segundo o filósofo, o conceito reúne três níveis imbricados: quanto ao seu ser, a rede é uma estrutura composta de elementos em interação; 
quanto à sua dinâmica, é estrutura de interconexão instável e transitória; quanto à sua relação com um sistema complexo, é uma estrutura encoberta cuja dinâmica presume explicar como funciona o sistema visível.

Os primeiros estudos das redes têm seus registros datados do século XVII, com a visão da rede subterrânea por Athanasius Kircher (FINDLEN, 2004) e mais tarde, no século XVIII, pelo matemático Leonhard Euler, responsável por fundar a teoria dos grafos ao realizar o estudo para solucionar o problema das sete pontes de Königsberg, em 1736 (NEWMAN, 2006). Porém é no século XX que a ciência das redes evolui significativamente, apresentando intensa produção de conhecimento e descobertas fundamentais em diversas vertentes, baseadas, essencialmente, em aportes matemáticos objetivando representar graficamente o fenômeno das conexões e das dinâmicas das redes, como: (i) análise de redes sociais - oriunda das Ciências Sociais, a ARS está associada a um conjunto de métodos e técnicas que buscam compreender as estruturas sociais a partir das relações entre atores sociais. (NEWMAN, 2006); (ii) teoria dos grafos - parte da matemática aplicada para descrição de redes, que se dedica ao estudo das propriedades estruturais e funcionais dos diferentes tipos de grafos, ou seja, da representação de uma rede composta por um conjunto de nós conectados por um conjunto de arestas (WEST, 2001). Dentre as descobertas matemáticas mais significativas que impulsionaram o desenvolvimento da Ciência das Redes, é possível evidenciar os estudos de Solomonoff e Rapoport (1951) e de Erdos e Rényi (1960). Com a teoria dos grafos aleatórios, eles entenderam o processo de formação da rede em que os nós são interligados aleatoriamente, os nós têm aproximadamente as mesmas quantidades de conexões e igualdade de condições de receber novas ligações. Esta teoria dominou o estudo das redes durante grande parte do século XX (BARABÁsI, 2003); (iii) fenômeno do mundo pequeno: proposta que tem como base modelos matemáticos e refere-se à conectividade. Nascido da experiência do mundo pequeno produzida por Staley Milgram, em 1967, o efeito do mundo pequeno parte da hipótese de que cada pessoa está ligada a qualquer outra no mundo através de uma cadeia curta de relações sociais; força dos laços fracos: contribuição do sociólogo Mark Granovetter (1973) para o problema de estruturação das redes sociais. Em estudo publicado no início da década de 70, o sociólogo demonstra que a sociedade é constituída por diversos grupos de pessoas que possuem laços fortes, ou seja, laços constituídos pelas relações de amizade e intimidade, e por laços fracos, ou seja, interações mais pontuais e superficiais. Estes últimos grupos são chamados clusters (agrupamento), sendo eles muito mais importantes na manutenção da rede social; (iv) redes livres de escala: Os estudos de Barabási e Albert (1999) apontam para a existência de redes que possuem uma dinâmica em sua estruturação, como a internet, World Wide Web ou as redes biológicas. Nestas redes, o grau 
de conexão não é igualitário, ou seja, é possível encontrar em sua estrutura alguns nós com um grande número de ligações com outros (hubs ou conectores), enquanto a outra grande maioria dos nós, apresenta um baixo grau de conexões.
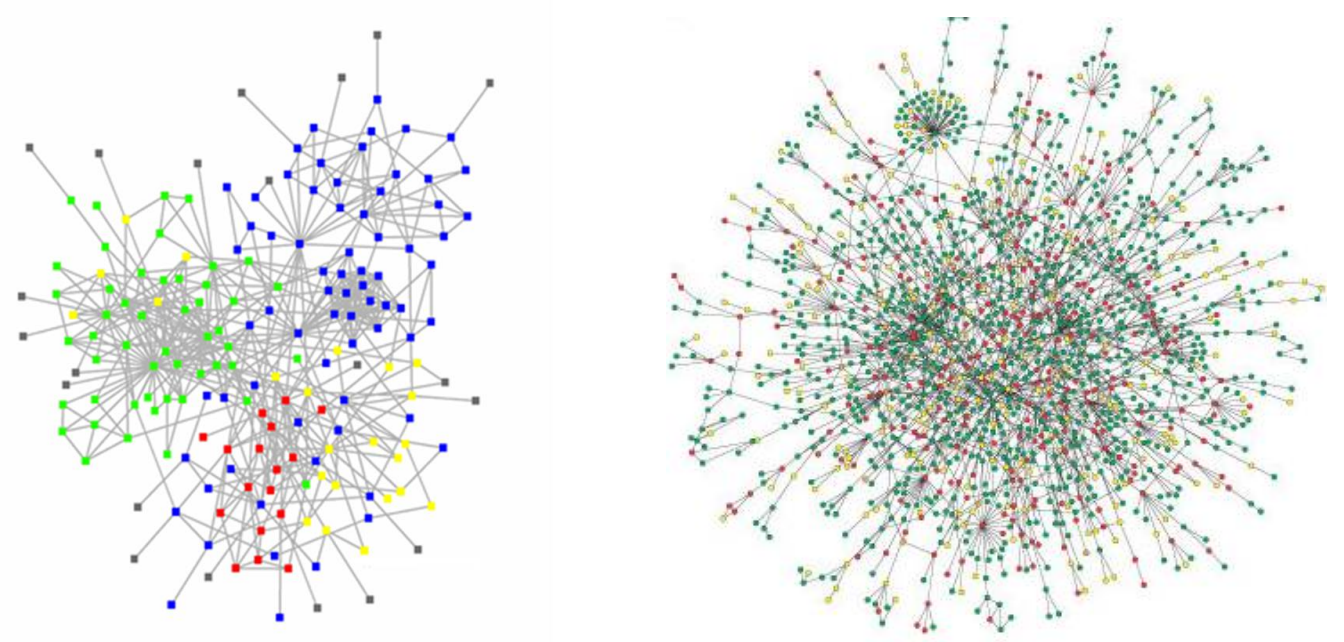

FIGURA 07: MODELOS DE REDES ${ }^{14}$

Sejam elas naturais ou artificiais, as redes apresentam uma série de características em comum, fazendo com que a nova ciência das redes encontre aplicação nas mais distintas áreas do conhecimento. Na figura à esquerda, a representação da estrutura de uma organização. Na direita, a representação de redes de proteína numa célula.

O advento da internet na década de 90 não só popularizou o termo rede, em grande medida associada à rede de computadores, como alavancou um novo campo de pesquisa denominada nova Ciência das Redes (BARABÁSI et al., 2002; WATTS, 2003), que evolui significativamente, ganhando relevância e aplicação crescentes nas mais diversas áreas. Para Castells (2003, p.7), "as redes ganharam vida nova em nosso tempo, transformando-se em redes de informação energizadas pela internet, que passa a ser a base tecnológica para a forma organizacional da era da informação: a rede."

Na obra "A Galáxia da Internet”, Manuel Castells (2003, p.8) explora os efeitos dos extraordinários avanços nas telecomunicações e na computação, possibilitados pela revolução microeletrônica. Para isso, o sociólogo parte de uma abordagem histórica do processo de criação da internet, objetivando demonstrar como esta tecnologia, no primeiro momento, essencialmente aplicada em espaços isolados dos cientistas computacionais, das comunidades contraculturais e dos hackers, se tornaria a força motriz na transição para uma nova forma de

\footnotetext{
${ }^{14}$ Imagens disponíveis no endereço eletrônicos http://www.orgnet.com/email.html. Acesso em: 01 dez. 2016.
} 
sociedade, nomeada por ele "sociedade de rede", e, com ela, a condução rumo a uma "nova economia".

Ao dissertar sobre a criação e desenvolvimento da Internet, Castells aponta o advento desta como uma consequência de fusões singulares de cooperação, alta tecnologia e inovação. Segundo o sociólogo, foi alicerçada nestes valores que a internet foi criada nas três últimas décadas do século XX. Sua origem está no trabalho da inovadora instituição de pesquisa ARPA (Agência de Projetos de Pesquisa Avançada do departamento de defesa dos Estados Unidos). Criada a partir da ideia inicial do Departamento de Defesa Americano de desenvolver um sistema descentralizado de comunicação militar, a internet passaria por sucessivas evoluções até chegar às condições tecnológicas capazes de oferecer uma comunicação global horizontal. Para isso, foi necessário desenvolver uma linguagem digital comum e um sistema de comunicação baseado em uma lógica de redes.

O projeto de rede comunicativa acentrada e distribuída foi concebido pelo pesquisador Paul Baran em 1964. Os diagramas de Baran demonstram a diferença de topologias ou padrões de conexão em três modelos de redes, como nas figuras dos grafos abaixo extraídas do relatório "On Distributed Communications". Nele, Baran identifica três modelos de redes e analisa a eficiência destes modelos de acordo com cada uma de suas estruturas. São eles: i) Modelo de Rede Centralizada: demonstra a existência de um nó responsável por centralizar a maior parte das conexões. Nele, é produzida uma comunicação em uma só direção, sendo distribuída a partir de um centro produtor e armazenador das mensagens. ii) Modelo de Rede Descentralizada: aqui a rede apresenta vários centros, sendo conectada por um pequeno grupo de nós que se conecta a outros grupos; iii) Modelo de Rede Distribuída: neste modelo todos os nós possuem mais ou menos a mesma quantidade de conexões, sem uma valoração hierárquica entre eles. Aqui a informação flui de maneira horizontal, dialógica, e distribuída, sem restrição a um só centro ou a diversos centros, como visto nos modelos anteriores. 


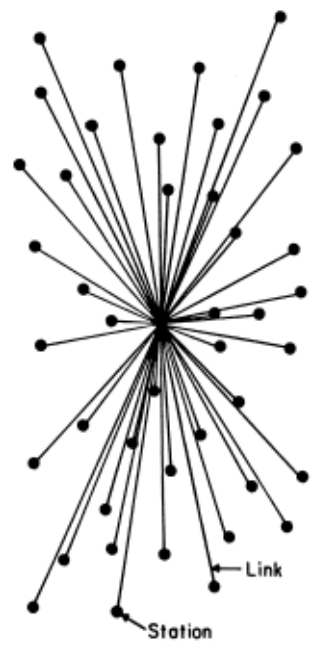

CENTRALIZED

(A)

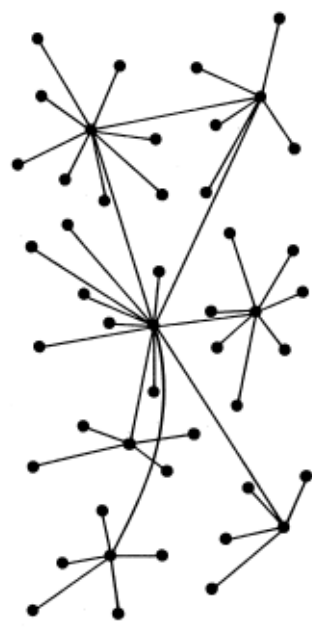

DECENTRALIZED

(B)

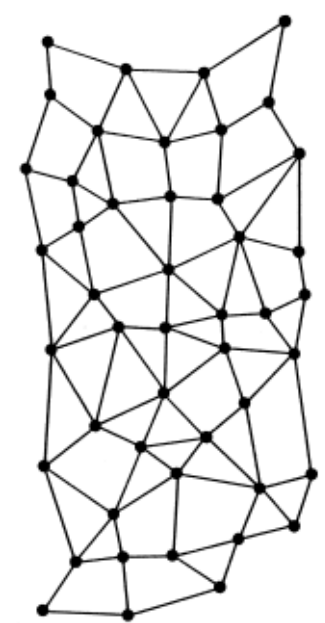

DISTRIBUTED

(C)

FIGURA 08: DIAGRAMAS DAS REDES DE BARAN $(1964)^{15}$

Os três modelos de redes apresentados pelo engenheiro para a criação do de comunicação militar capaz de resistir a uma destruição parcial.

Foi o terceiro modelo, aquele que oferecia uma rede tecida como uma teia, que serviu como base para a formação da rede comunicativa ARPANET, que originaria a internet como um modelo comunicativo mundial e aberto. Já por volta de 1990, um novo avanço tecnológico permitiu a disseminação da internet na sociedade, facilitando o acesso para empresas privadas e para o público em geral. A criação do protocolo HTTP (HIPER TEXT TRASFER PROTOCOL) e da linguagem HTTP (HYPER TEXT MARKUP LANGUAGE) consegue organizar os conteúdos na internet por informações e oferece facilidade de navegação ao usuário (CASTELLS, 1999, p. 87-88). A criação do World Wide Web, o "www", pelos pesquisadores Tim Berners Lee e Robert Cailliau impulsionaria uma década de expansão da internet, provocando a reorganização de toda a arquitetura da comunicação por meio da codificação da linguagem em bits.

A partir deste ponto, a internet vai se consolidando e ganhando popularidade entre os usuários, que assimilam as rápidas evoluções das dinâmicas e modalidades de interação oferecida por esta teia global. Tal novidade ganha relevância e empresas de internet começam a ser criadas. A expansão dos serviços comerciais teve um papel importante na popularização da internet. Nos anos 90, acompanhamos a explosão das nomeadas empresas ponto-com, que

15 Imagem extraída do memorando On Distributed Communications (1964). Disponível em: http://www.rand.org/content/dam/rand/pubs/research_memoranda/2006/RM3420.pdf. Acesso em: 01 dez. 2016. 
utilizavam os recursos e as linguagens tecnológicas da web $1.0^{16}$ para projetar seus softwares proprietários e aplicativos fechados. Neste período, os negócios ocupavam este ambiente através de sites estáticos criados com a linguagem HTTP, que não permitiam ao usuário muita interação. Ancorado em um modelo comunicativo hipodérmico ${ }^{17}$, a estrutura do processo comunicativo se dava através do controle da produção e transmissão das informações na figura de um emissor - o webmaster. Ele dominava o código de linguagem e anulava qualquer possibilidade de intervenção do internauta, que assumia o papel de espectador. Embora algumas iniciativas criassem os primeiros gêneros digitais como e-mail, chat e fórum, majoritariamente os conteúdos fluíam obedecendo uma concepção linear e uma perspectiva frontal.

Com efeito, com a disseminação da web, a internet comercial brasileira cresceu rapidamente. Os empreendedores brasileiros exploram as tendências da web americana, como serviços de e-mail, buscadores, lojas virtuais e portais, desenvolvendo negócios como o buscador cadê (1995); webmail ZipMail (1995) e o Portal Uol (1996). Uma referência da descoberta comercial da internet no Brasil na década de 90 foi o comparador de preços Buscapé. Fundado por quatro estudantes da USP, o site de busca e comparação de preços sobreviveu ao "estouro da bolha" nos Estados Unidos no final da década e é o maior nome em seu segmento na América Latina.

Os modelos de negócios das empresas de internet foram sofrendo grandes mudanças desde a década de 90, sempre acompanhando o processo de evolução contínua da rede. $\mathrm{Na}$ segunda geração, denominada web 2.0, a estrutura comunicativa teve a sua linearidade frontal rompida. Para Di Felice et al. (2008, p. 52-53), a emergência de uma arquitetura de comunicação digital e dialógica consolida uma alternativa ao modelo analógico e dialético de monopólio da informação e fonte de emissão de conteúdo para uma audiência receptora e

\footnotetext{
${ }^{16}$ Lucia Santaella (2013) aponta que "a nomenclatura das 'webs 1.0, 2.0, 3.0' começou a ser empregada depois da expressão 2.0 e foi apresentada por Tim O'Reilly para se referir a uma espécie de segunda geração de aplicativos, comunidades e serviços de que a web seria a grande plataforma (2013, p.40 e 41). A pesquisadora analise que a partir do fenômeno revolucionário das mídias móveis computadorizadas, é possível delimitar a idade digital em três eras, sendo elas: (i) a era do microcomputador (Web 1.0), quando o desktop, e-mails e banco de dados foram os maiores destaques; (ii) a era do www (Web 2.0), marcada pela liberação do polo emissor, a emergência das redes sociais e colaborativas. (iii) a era web semântica (Web 3.0), que tem como principal característica a computação em nuvens.

${ }^{17}$ Di Felice et al (2012, p. 40) definem o modelo comunicativo hipodérmico como aqueles estudos "caracterizados pela incidência direta da mensagem, enviada por uma fonte emissora E, sobre o receptor R, que seria incapaz de escapar à sua influência e inseridos dentro da perspectiva teórica da comunicação de massa (...).Tais estudos evidenciavam também a linearidade e a unidirecionalidade do envio da mensagem, colocando o controle da produção e da transmissão da mesma nas mãos do emissor e desconsiderando qualquer possibilidade responsiva por parte do destinatário, aqui tomada como uma massa passiva e anônima e passíveis de responderem individualmente e isoladamente às manipulações e persuasões que os alcançam através desses meios.”
} 
passiva, ultrapassando a tradicional e hierárquica dicotomia emissor-receptor. Esta arquitetura comunicativa digital passa a oferecer aos indivíduos uma experiência de conteúdos dinâmicos para criação, compartilhamento de informações e cooperação, através do amadurecimento de recursos e da introdução de novas plataformas de relacionamento, produção de conteúdo, aprendizagem e colaboração.

Assim, com o digital, a comunicação deixa de ser somente um conjunto de ações cujo objetivo é tornar comum uma mensagem ou anúncio e passa a agregar um conjunto de plataformas, trocas informativas e de produção de relacionamentos. O desenvolvimento da web incrementa a natureza relacional da comunicação digital, fazendo emergir novos protagonismos na medida em que desloca seus usuários para uma posição de agentes produtivos do contexto digital (DI FELICE et al, 2012). Nesta fase de maturidade da internet, surgem negócios que exploram áreas como lojas online para produtos de nichos, sites de compras coletivas, sites de vídeos online e blogs, como: a plataforma de vídeo brasileira Sambatech (2004), a rede de publicidade em blogs Boo-box (2007) e o site de compras coletivas Peixe Urbano (2010).

Para Castells (2003), o desenvolvimento da internet vem criando uma estrutura de ambiente tecnológico que abriga o desenvolvimento de diversas redes, sendo a internet a rede das redes ${ }^{18}$. A partir de uma relação direta com as mudanças na complexidade dos processos comunicativos, como efeitos do novo paradigma tecnológico da informação alicerçado na comunicação, Castells analisa que no final do século XX emerge uma nova estrutura social predominantemente baseada em redes, operadas por tecnologias de comunicação e informação e fundamentada na microeletrônica e em redes digitais de computadores.

\subsection{SOCIABILIDADE}

Na obra "A sociedade em rede" (1999), primeiro volume da trilogia "A era da Informação: economia, sociedade e cultura", Castells ancora-se na revolução da tecnologia da informação para analisar a formação e a dinâmica social e econômica da era da informação, cujos processos estão cada vez mais organizados em torno de redes. Ao desempenhar um papel central na caracterização da sociedade na era informacional, para o autor, "as redes constituem a nova morfologia social de nossas sociedades e a difusão da lógica de redes modifica de forma

18 Os parágrafos a seguir apresentam alguns fragmentos do artigo 'A Economia na Sociedade em Rede: as transformações sociais e econômicas no contexto de hipercomplexidade das redes, por ocasião de minha participação no XIV Congresso Internacional Ibercom 2015. 
substancial a operação e os resultados dos processos produtivos e de experiência, poder e cultura". Ao analisar as estruturas sociais emergentes, Castells reconhece o novo paradigma da tecnologia da informação como o responsável por "fornecer a base material para expansão penetrante das redes em toda a estrutura social, caracterizada pela primazia da morfologia social sobre a ação social.” (CASTELLS, 1999, p. 565)

Assim, à medida que o novo paradigma tecnológico interage com a economia e a sociedade, provoca não só a promoção de um novo sistema de comunicação baseado em uma linguagem universal digital e responsável por provocar uma interação global de produção e distribuição, como também provoca um processo profundo de reestruturação do capitalismo, caracterizado por maior flexibilidade de gerenciamento, descentralização das empresas, diversificação das relações de trabalho, bem como a acumulação e gestão de capital.

Imersa em um novo paradigma tecnológico organizado em torno de novas tecnologias da informação mais poderosas, flexíveis, abrangente e complexa, a nova economia, nomeada por Castells de economia informacional, está estruturada em um tipo de capitalismo também informacional. Um capitalismo que apresenta como distinções fundamentais ser global e estar estruturado, em grande medida, em uma rede de fluxos financeiros, onde o acesso ao knowhow tecnológico torna-se fundamental para a produtividade e a competitividade. Nesta estrutura, o capital funciona globalmente como uma unidade em tempo real, sendo percebido, investido e acumulado principalmente na esfera de circulação, ou seja, como capital financeiro. Assim, a realização de valor passa a ser cada vez mais gerada nos mercados financeiros globais estabelecidos pelas redes de informação, no espaço intemporal de fluxos financeiros.

Surgida no último quarto do século $\mathrm{XX}$ em função da revolução da tecnologia da informação, a economia informacional apresenta uma estrutura econômica cuja produtividade e competitividade dependem da capacidade da economia de gerar, processar e aplicar a informação baseada no conhecimento. Assim, a economia informacional é "uma economia em rede profundamente independente que se torna cada vez mais capaz de aplicar seu progresso em tecnologia, conhecimentos e administração na própria tecnologia, conhecimentos e administração" (CASTELLS,1999, p. 119-120).

O novo sistema econômico anunciado por Castells está associado ao surgimento de um novo modelo de desenvolvimento, o informacionismo. Seu modelo encontra no processamento de informação e na comunicação simbólica as fontes centrais de produtividade da sociedade, e, no novo paradigma tecnológico baseado na informação, os seus princípios organizadores. Para o sociólogo, "as redes são os instrumentos adequados para uma economia baseada na inovação, na globalização e na concentração descentralizada.” É deste contexto de redes que emergem 
"trabalho, trabalhadores e empresas voltadas para a flexibilidade e adaptabilidade, bem como para uma cultura de construção e desconstrução contínuas." (CASTELLS, 1999, p. 566).

O sociólogo italiano Di Felice (2013, p.60-62) observa que é possível encontrar não só na contribuição do Manuel Castells como em muitos estudos das redes digitais um grande consenso na qualificação do poder de disseminação de conteúdo, ideias e informações como sendo a função central das redes sociais digitais. Tal perspectiva pode ser evidenciada no significativo volume de estudos dedicados às análises de processos de disseminação, como cartografia de relações e identificação de tipos de laços. Nestes estudos, as arquiteturas informativas digitais são percebidas e estruturadas nas suas funções sociais, inscrevendo as atividades informativas produzidas por estas redes dentro de uma esfera maior, cuja composição é o próprio sistema social. São abordagens que não põem em questão os conceitos de interação e de sociedade, conclui o sociólogo.

Com efeito, o conceito de redes em Castells é sociológico. Elas expressam um social antropomórfico e uma concepção social dos processos de comunicação e das redes digitais. Entendidas como um conjunto de nós interconectados, eles podem ser uma rede de fluxos financeiros globais, conselhos nacionais de ministros, comissários europeus da rede política que governa a União Europeia, sistemas de televisão, laboratórios clandestinos, ou até pistas de aterrissagem secretas. As "redes são estruturas abertas capazes de expandir de forma ilimitada integrando novos nós desde que consigam comunicar-se dentro da rede, ou seja, desde que compartilhem os mesmos códigos de comunicação" (CASTELLS, 1999, p.498).

Um outro estudo que tem sido adotado como aporte teórico-metodológico nas pesquisas realizadas em contextos relacionados à comunicação digital e às redes digitais é a teoria atorrede. Ela caracteriza-se por apresentar diferente significado social e comunicativo para a concepção de redes e propor um dinamismo não sistêmico e não socialmente estruturado ${ }^{19}$. É na obra "Reagregando o Social" (2012) que Bruno Latour reúne o conhecimento produzido em parceria com Michel Callon, John Law, Madeleine Akrich, Andy Barry, Annemarie Mol, Antoine I-lennion, entre outros intelectuais, e apresenta de maneira sistemática e introdutória a Teoria Ator-Rede $\left(\mathrm{ANT}^{20}\right)$. Nascida no âmbito dos estudos de ciências e tecnologias, a ANT, estendeu-se para uma crítica à sociologia, podendo esta ser definida como a teoria que "coloca em questão a noção de social e de sociedade, de ator e de rede” (LEMOS, 2013, p. 31).

\footnotetext{
${ }^{19}$ Os parágrafos a seguir apresentam alguns fragmentos do artigo 'Teoria Ator-Rede: uma alternativa para pensar a Comunicação em contextos digitais', por ocasião de minha participação no XXXVIII Congresso Brasileiro de Ciências da Comunicação - Rio de Janeiro, RJ no ano de 2015.

${ }^{20}$ De Actor-Network Theory. Teoria Ator-Rede, em português.
} 
Objetivando mostrar os limites da sociologia da ciência - profundamente influenciada pelo estruturalismo e pelo pensamento durkheimiano, os sociólogos das associações ${ }^{21}$ concebem uma teoria do social capaz de pensar o híbrido e de pressupor uma ontologia plana, em que, para análise do social, as ações são consideras como sendo hierarquicamente equivalentes entre humanos e não-humanos ${ }^{22}$.

Tais princípios tornam-se de grande relevância para o estudo das redes ao incitar a pensar a cultura digital e, sobretudo, a comunicação digital fora de estruturas explicativas e categorias que induzem à purificação desses híbridos e à separação entre sujeito e objeto, natureza e cultura, humano e não-humano. Dentro desta perspectiva, alinhada também à possibilidade metodológica de acompanhar rastros e revelar as diversas dimensões de redes em formação, é que a ANT vem ganhado espaço e sendo aplicada nos mais diferentes contextos de pesquisa e nos mais variados campos do saber, inclusive nos estudos da comunicação digital e das redes digitais. Por ser um campo privilegiado da ação desta relação entre mediadores e por suas ações deixarem rastros (e o digital permitir visualizar esses rastros), esta é uma área interessante para a aplicação e discussão a partir da $\mathrm{ANT}^{23}$.

Na publicação “A comunicação das coisas” (2013), André Lemos relaciona alguns conceitos e fundamentos da teoria ator-rede à comunicação digital e à cibercultura, apresentando-nos também algumas possibilidades de aplicação da ANT nesses campos. Segundo ele, a ANT pode ajudar-nos a revelar fenômenos e associações como a sociabilidade online, a análise dos rastros deixados por várias ações na internet, as mídias locativas, o corpo e a subjetividade, as interfaces e interações dos dispositivos móveis, a arte, o ciberativismo, os games, a inclusão digital e a internet das coisas. Lemos (2013, p.23) acredita que para a área de comunicação e para os estudos da cibercultura, a presença de uma teoria que pense os mediadores sem dar muitos privilégios aos atores sociais clássicos, nivelando topologicamente sujeitos e objetos, atores humanos e não humanos parece bem apropriada para pensar a cultura digital.

Entretanto, na construção de seu pensamento sobre rede, em nenhum momento Latour faz referência às redes digitais. Quanto à ideia de rede que completa a expressão ator-rede,

\footnotetext{
${ }^{21}$ Faz referência à "sociologia de associações" empregada por Latour para redefinir a sociologia não como ciência do social, mas como uma busca de associações entre elementos heterogêneos. (LATOUR, 2012, p.27).

22 'Non-human' is my technical term to designate objects freed from the obligation to do politics through nature. Nature is here considered as what assembles all entities into one whole. It is thus a political definition that is sometimes opposed to human politics or, as is the case here, merged with politics" (LATOUR, 1998, p. 222).

${ }^{23}$ Fala do professor André Lemos na conferência realizada no SimSocial - Simpósio de Tecnologias Digitais e Sociabilidade $2012 \mathrm{em}$ Salvador/BA. Disponível em https://www.youtube.com/watch?v=2icCLBiuWkA. Acesso em 20 jul. 2015.
} 
Latour a define como aquilo que se forma das mediações. Ela seria, então, composta pelas associações em um constante movimento que se faz e se desfaz, ou seja, o movimento do social em formação. A palavra "rede" que acompanha o termo ator não guarda o significado de sociedade. "Rede é conceito, não coisa. É uma ferramenta que nos ajuda a descrever algo, não algo que esteja sendo descrito". (LATOUR, 2012, p.192). Assim, podemos perceber aqui uma concepção diversa da rede pensada quando nos referimos às redes digitais. Para a "sociologia das associações" a rede não é infraestrutura, mas sim aquilo que se forma a partir das relações entre as coisas, em um constante movimento rizomático de construção e desconstrução ${ }^{24}$.

Ao permitir pensar a agregação de coisas separadas como humano, técnica, meio ambiente e informação, ANT conquista espaço nos estudos realizados em contextos dinâmicos de redes e comunicação digital, onde é possível observar em escala crescente a presença dos dispositivos eletrônicos e redes telemáticas, dispositivos móveis, internet das coisas e territórios informativos. A ampliação da complexidade dos processos comunicativos exige o esforço de pensar as redes sociais e técnicas em suas circulações.

Nesta direção, a perspectiva teórica da rede latouriana, somada ao potencial conectivo das redes digitais, incita a pensar a comunicação em uma perspectiva ecológica e complexa. A comunicação digital percebida como um complexo processo entre as arquiteturas comunicativas, as informações e as pessoas, assim como analisa Di Felice (2015).

A comunicação digital apresenta-se como uma nova arquitetura da comunicação no interior do qual os fluxos informativos não se apresentam mais como uma sequência de mensagens geradas por um emissor e direcionada aos receptores. Tal estrutura comunicativa foi substituída por circuitos informativos que constituem um conjunto de redes interligadas entre si. Consequentemente a emissão deixa de ser o resultado de um repasse de informações frontais, isso é de um centro emissor, para um conjunto de receptores. Para se transformar em troca interativa de circuitos, pessoas, interfaces, cuja coação será a dinâmica criadora do processo comunicativo ${ }^{25}$.

Com efeito, com a nova fase da web, a web semântica ou web 3.0, caracterizada pela conectividade, mobilidade e ubiquidade, a introdução de tecnologias como as redes inteligentes (Smart Networks), máquina a máquina (M2M - Machine to Machine), computador em nuvem (cloud computing) e megadados (big data) e, consequentemente, da internet das coisas (internet

24 Conferência de André Lemos no Ciclo de Conferências Redes Communitas. Por uma ideia ecológica da comunicação e do comum”, realizado em 2014 pelo Centro Internacional de Pesquisa Atopos ECA/USP. Disponível em: https://www.youtube.com/watch?v=vbIcCAvkmrU. Acesso em: 21 Jul. 2015.

${ }^{25}$ Material audiovisual referente pesquisa Redes Digitais e Sustentabilidade, realizada pelo Centro de Pesquisa Atopos (ECA/USP), com patrocínio máster da Petrobrás e apoio institucional da ECA/USP, disponível em: https://www.youtube.com/channel/UCVT7GXnGQBTcYNiXZFF9fvg. Acesso em 15 jun. 2015. 
of things), imprimem um novo dinamismo e horizonte ao empreendedorismo digital. Dos buscadores aos aplicativos móveis, no contexto de alta conectividade os arranjos econômicos exibem graus ainda maiores de inovação. A banda larga, os espaços wireless, a disseminação veloz, os telefones inteligentes e dispositivos de conexão ampliaram significativamente novos espaços de atuação e novos mercado de oportunidade para as startups digitais. Imersas em uma outra espacialidade, as startups aproveitam a oportunidade para criar valor a partir da exploração das condições e demandas produzidas por um ecossistema comunicativo de alta complexidade. Com isso, os modelos de negócios desses empreendimentos também mudam e prolifera a criação de aplicativos móveis, softwares para dispositivos eletrônicos móveis e de serviços. Os esforços desses empreendedores não estão voltados para receitas vindas de produtos ou publicidade, mas sim no faturamento vindo de taxas de serviços ou assinaturas. É uma geração que trabalha muito mais com bits do que com átomos, buscando estabelecer relações de acesso como: aplicativos para chamada de táxi, como o Easy taxi (2011); aplicativos de delivery de comida, como o iFood (2011); gerenciadores financeiros, como o Guia bolso (2014); e comunicação e networking em eventos corporativos, como o Inevent (2013).

No conceito de rede latouriano, é possível perceber as interpretações dos princípios do rizoma, conceito desenvolvido por Gilles Deleuze e Félix Guatarri (1995), que constitui-se em um importante pilar na construção de um modelo para a fundamentação epistemológica da Ciência das Redes. Com efeito, no final do século XX, o conceito de rizoma tornou-se a metáfora chave nos estudos de redes, especialmente aqueles voltados para o estudo da envolvendo a web e a hipermídia. Originado da botânica, o termo sofre ampliações e é adotado pelos filósofos passando a comportar o conceito de multiplicidade. Em contraposição à concepção arbórea do conhecimento, o conceito supera as dicotomias do inteligível e do sensível. Sem hierarquias e com múltiplos pontos de entrada e múltiplos pontos de saída, um rizoma trabalha com conexões horizontais e trans-espécies.

Um rizoma não começa nem conclui, ele se encontra sempre no meio, entre as coisas, inter-ser, intermezzo. A árvore é filiação, mas o rizoma é aliança, unicamente aliança. A árvore impõe o verbo "ser", mas o rizoma tem como tecido a conjunção "e... e... e..." Há nesta conjunção força suficiente para sacudir e desenraizar o verbo ser. Para onde vai você? De onde você vem? Aonde quer chegar? São questões inúteis. Fazer tabula rasa, partir ou repartir de zero, buscar um começo, ou um fundamento, implicam uma falsa concepção da viagem e do movimento (metódico, pedagógico, iniciático, simbólico...) (DELEUZE ; GUATARRI,1995, p. 36)

Na obra "Mil platôs" (1995) Deleuze e Guatarri nos apresentam as características aproximativas do rizoma através de seis princípios de funcionamento, sendo eles: 
(i) Princípio de conexão: "qualquer ponto de um rizoma pode ser conectado a qualquer outro e deve sê-lo" (DELEuZE; GUATTARI, 1995, p.15). Construído em contraposição ao princípio de causalidade, de previsibilidade e de determinismo, este princípio diferencia o rizoma do modelo arbóreo. Acentrado, o rizoma realiza conexões sem atender a uma ordem hierárquica ou de filiação, avançando em todas as direções. Neste modelo, são as conexões ou agenciamentos que modificam as linhas conectadas promovendo novas direções e condicionando futuras conexões;

(ii) Princípio de heterogeneidade: “(...) um método de tipo rizoma é obrigado a analisar a linguagem efetuando um descentramento sobre outras dimensões e outros registros" (DELEUZE; GUATTARI, 1995, p.16). O princípio da heterogeneidade evidencia que o rizoma não é de natureza linguística;

(iii) Princípio da multiplicidade: "uma multiplicidade não tem nem sujeito nem objeto, mas somente determinações, grandezas, dimensões que não podem crescer sem que mude de natureza (as leis de combinação crescem então com a multiplicidade)" (DELEUZE; GUATTARI, 1995, p.16). O rizoma não é composto de formas puras ou totalidades, mas sim composto de singularidades préindividuais, que estabelecem ente si agenciamentos, relações recíprocas, e conexões;

(iv) Princípio da ruptura a-significante: "Todo rizoma compreende linhas de segmentaridade segundo as quais ele é estratificado, territorializado, organizado, significado, atribuído, etc; mas compreende também linhas de desterritorialização pelas quais ele foge sem parar (Ibidem, p.17). Este princípio evidencia a composição do rizoma, feito de linhas, e revela a existência de uma tensão continua entre o movimento de criação de formas e organizações, e de fuga e desconstrução destas formas. "Há ruptura no rizoma cada vez que linhas segmentares explodem numa linha de fuga, mas a linha de fuga faz parte do rizoma. Estas linhas não param de se remeter umas às outras”. (Ibidem, p.17);

(v) Princípio da Cartografia: Princípio metodológico que aponta para o fato de que o pensamento sobre o rizoma não é representacional, mas inventivo. Como parte do rizoma, o mapa "é conectável em todas as suas dimensões, desmontável, reversível, suscetível de receber modificações constantemente". (Ibidem, p.22); 
(vi) Princípio da decalcomania: "Um mapa tem múltiplas entradas contrariamente ao decalque que volta sempre "ao mesmo". Um mapa é uma questão de performance, enquanto que o decalque remete sempre a uma presumida "competência" (Ibidem, p.22) Princípio aponta para a complexidade da relação entre mapa e decalque. O mapa enquanto construção, pode ser decalcado, mas não reproduzido.

\subsection{HABITAR}

Para Di Felice, Torres e Yanaze (2012), o advento do digital não diz respeito somente às transformações nos processos comunicativos e sociais no sentido sociológico clássico, mas aponta também para a configuração de uma nova condição habitativa. Pensar a rede e suas transformações exige repensar categorias modernas dos conceitos de social e de sociedade, bem como da natureza e da própria comunicação. Para Di Felice, trata-se de uma migração de um estatuto ecológico antropocêntrico para um estatuto ampliado e mais complexo que pensa "a natureza e o mundo como um conjunto de relações comunicativas articuladas através de dinamismos criadores de redes de redes.” (DI FELICE, 2009, p. 29)

A revolução digital altera a própria arquitetura do processo informativo, substituindo a forma frontal de repasse das informações por uma forma reticular e colaborativa, fazendo emergir práticas interativas inéditas entre as pessoas, circuitos informativos, territórios e os dispositivos de conectividade. As redes digitais, ou seja, o conjunto de redes de redes em interrelações entre elementos de diversas naturezas, produzem um processo comunicativo em rede como um ecossistema, sujeito a um conjunto de relações com outros ecossistemas no interior da biosfera que torna cada um deles parte de uma rede de redes ${ }^{26}$.

Para Di Felice (2009), o processo de digitalização ${ }^{27}$ do território e a sua transformação em fluxo informativo e móvel produz uma emancipação do lugar e um tipo de interação com estes territórios, não mais transitiva e externa. Os espaços wireless, os dispositivos móveis conectivos, os objetos infocomunicativos e as tecnologias de sistemas informativos

26 Disponível em: http://www.ihu.unisinos.br/entrevistas/500515-pos-complexidade-as-redes-digitais-vistas-apartir-de-uma-perspectiva-reticular-entrevista-especial-com-massimo-di-felice. Acesso em 10 ago. 2016.

${ }^{27}$ Aqui cabe também explicarmos a noção de digitalização empregada pelo sociólogo. A concepção do processo de digitalização aqui é compreendido não exclusivamente como a troca de informações entre membros humanos em um processo de interação tecnocomunicativa, mas em uma noção ampliada da digitalização para uma dimensão territorial, que compreende todos os coletivos que o compõem, como os espaços, pessoas, meio ambiente, as arquiteturas informativas, dispositivos, as realidades sociais e econômicas, em um processo de transfiguração, em suma, a digitalização é aqui compreendida como um processo que envolve as trocas informativas, bem como os coletivos técnicos, ambientais e naturais como parte ativa dos conjuntos de redes (DI FELICE et al. 2012). 
geográficos, por exemplo, instauram novas percepções e interações reticulares entre sujeitosterritórios, bem como um dinamismo técnico, que altera continuamente o senso de lugar e as práticas do habitar.

Na obra "Paisagens Pós-Urbanas: o fim da experiência urbana e as formas comunicativas do habitar" (2009), o sociólogo Massimo Di Felice investiga a importância e o papel das tecnologias de comunicação na construção das relações com o território e nas práticas habitativas, cujas características formantes não são um residir ou estar, mas sim a qualidade de se relacionar e de comunicar. A partir da noção de habitar desenvolvida pelo filósofo alemão Martin Heidegger (2006), o sociólogo italiano apresenta três formas comunicativas históricas do habitar, relacionando-as a quatro tecnologias de comunicação, sendo elas: (i) o habitar empático como forma de interação com o território mediada pela escrita e pelas práticas da leitura; (ii) o habitar exotópico como forma de interação com o meio ambiente a partir da fotografia, da eletricidade e dos meios eletrônicos de massa; (iii) o habitar atópico que, ligado ao processo de digitalização e ao advento das tecnologias interativas digitais conectadas em redes, refere-se à forma de interação mediada por dispositivos digitais, suas interfaces e software, que produzem interações habitativas dinâmicas, espacialidades manipuláveis e temporalidades habitáveis, somente quando em conexão com suas expressões reticulares

A forma de habitar contemporâneo atópico refere-se a uma forma não mais antropomórfica de habitar. Uma pós-territorialidade que supera as formas físicas dos espaços, substituindo-as por uma forma informativa digital e transorgânica, constituída por tecnologias informativas digitais e as redes sociais, composta da fusão dos coletivos inteligentes e dos dinamismos das linguagens transorgânicas. Trata-se de uma forma comunicativa do habitar informativo, pós-geográfico e pós-arquitetônico, que se configura "como o advento de uma nova tipologia de ecossistema, nem orgânica, nem inorgânica, nem estática nem delimitável, mas informativa e imaterial" (DI FELICE, 2009, p. 291). 


\section{CARACTERIZAÇÃO DAS STARTUPS}

Quando tomamos o vocábulo startup em uma tradução direta da língua inglesa, este pode ser entendido como começar ou iniciar. Tradicionalmente o termo é atribuído a qualquer empresa no estágio inicial. Entretanto, para o Vale do Silício, região norte-americana reconhecida como grande polo de inovação nos campos científico e tecnológico, berço de corporações gigantes como Google, Yahoo, Facebook, Apple Inc., Microsoft e eBay, as startups ganham significado especial, sendo consideradas também como iniciativas de inovação e tecnologia.

Esta noção de startup ficou popularizada na década de noventa, especialmente com o acontecido com a bolha das empresas ponto- $\operatorname{com}^{28}$, no final dessa mesma década. Nos últimos vinte anos, a emergência e a expansão das novas iniciativas de base tecnológica principalmente aquelas que oferecem produtos e serviços de tecnologia da informação e comunicação - têm se apropriado do termo para fazer referência a suas práticas emergentes de empreendedorismo intrinsecamente relacionadas com o advento das tecnologias digitais.

Ao tomarem para si a terminologia, essas iniciativas acabaram por redimensionar e incorporar outros significados ao termo. Falar de startups tecnológicas no atual contexto é ir além de sua condição de estágio inicial. Essas iniciativas trazem singularidades outras e ganham novas propriedades quando imersas em contexto tecnológico de informação e comunicação, produzindo um afastamento das startups que assim se reconhecem e se definem em função exclusiva do seu estágio inicial de atividade.

Este afastamento conceitual pode ser identificado nos estudos realizados por Ries (2012). Inquieto com as limitações apresentadas pelo pensamento tradicional da administração para conduzir os processos de concepção e de desenvolvimento das iniciativas de inovação, ele realiza um esforço para produzir um pensamento capaz de iluminar os caminhos inéditos das práticas de inovação neste contexto digital emergente, registrado na obra A Startup Enxuta (2012), onde propõe uma nova abordagem e método para a prática do empreendedorismo no século XXI.

Embora esta abordagem tenha sido produzida com o interesse de criar um método capaz de gerar um processo inteligível para as empresas nascidas no ambiente tecnológico da informação e comunicação, podemos, de seu interior, extrair a concepção de startup ali operada.

\footnotetext{
${ }^{28}$ Bolha das empresas ponto com ou bolha da internet refere-se a bolha especulativa ocorrida entre 1995-2000. Corresponde ao período no qual as ações de tecnologias listadas na Nasdaq (bolsa de valores das empresas de tecnologia), atingiram níveis irreais, muito além da capacidade de geração de resultados futuros.
} 
Para Ries (2012, p.24), a startup consiste em "uma instituição humana projetada para criar novos produtos e serviços sob condições de extrema incerteza". Em sua definição, suas atenções estão fundamentalmente voltadas não para o estágio dessa instituição, seu tamanho, mercado ou o setor da economia em que estão inseridas, mas sim para a condição de incerteza em que elas operam, sendo esse então o elemento de uniformidade que singulariza, caracteriza e define estas novas iniciativas de inovação. Nesta definição, dois pontos nos ofereceram importantes aberturas para reflexão: o primeiro refere-se ao contexto de incerteza dessas iniciativas; e o segundo diz respeito à compreensão dessas iniciativas como instituições humanas.

\section{- A incerteza ao extremo}

Neste primeiro momento, nos dedicaremos a refletir sobre a condição de incerteza em que essas startups atuam, embora a separação precisa desses momentos represente um grande desafio para um pensamento que é tecido junto. Estas ações empreendedoras, em grande medida, dedicam-se à criação de novos mercados ou a mudanças de experiências naqueles mercados já existentes, como: fazer de cada smartphone um ponto de taxi (Easy Taxi); alugar espaços ociosos para hospedagem (Airbnb); acessar e compartilhar arquivos pessoais em qualquer lugar (Dropbox); trocar mensagens instantâneas via celular gratuitamente (Whatsapp); deslocar-se por meio de mapas atualizados sobre condição de tráfego e estradas em tempo real (Waze); realizar transações financeiras sem a participação de instituições bancárias (Biva); usar o tempo como moeda de troca (Bliive $)^{29}$.

Os novos idealistas, como exploradores, percorrem trajetórias não convencionais, atuando no fluxo, no imprevisível e ocupando espaços fora das grandes estruturas. Nesse percurso transitivo, os princípios lineares e os instrumentos de controle típicos da prática do empreendedorismo tradicional, com suas ferramentas projetadas para seccionar, isolar, separar, provisionar, projetar e controlar, parecem apresentar assimetrias com um fazer aberto ao devir e ao acontecimento das redes.

Para os estudos do movimento Lean Startup, tais instrumentos ancorados nos princípios da Teoria Geral da Administração (CHIAVENATO, 2003) - teoria esta responsável pela criação das grandes empresas ao longo do século XX - parecem apresentar incompatibilidades com

29 Sites das startups citadas: Airbnb. Disponível em: https://www.airbnb.com.br/; Easy Taxi. Disponível em: http://www.easytaxi.com/br/. Dropbox. Disponível em: https://www.dropbox.com/pt_BR/; Waze. Disponível em: https://www.waze.com/pt-BR; Whatsapp. Disponível em: https://web.whatsapp.com/ . Biva. Disponível em: https://biva.com.br/ e Bliive. Disponível em: https://bliive.com/?lang=pt-br. Acessos em 01 jun. 2016. 
uma prática de empreendedorismo cuja emergência no caos, no movimento, no alto grau de incerteza aparece como elemento caracterizante intrínseco. São iniciativas que parecem não mais apresentar uma lógica sistêmica ou obedecer aos modelos tradicionais de semiexternalidades, mas que se realizam em uma lógica de redes de redes, cujas relações e fluxos se estabelecem em uma multiplicidade de interações, revelando uma ausência de totalidade e linearidade.

\section{- Dimensão humana}

Neste segundo momento, um outro aspecto que nos oferece espaços para ampliarmos nossa reflexão refere-se à dimensão humana que o autor atribui às startups em sua abordagem. Entendê-las como uma instituição humana, parece-nos insuficiente, uma limitação conceitual. O modo como as startups se organizam entre os diversos elementos que as compõem e nas suas relações com a ambiência em que elas estão inseridas, realizando-se por meio da produção de um conjunto de interações contínuas entre espaços, pessoas, tecnologias, informações, objetos e inteligências, nos oferece a possibilidade de pensarmos as startups para além de uma instituição humana (RIES, 2012): como redes de relações interdependentes e comunicantes altamente complexas que acontecem em seu interior e na sua relação com as tecnologias digitais e com o ambiente em que elas estão imersas.

Isso provoca-nos a pensar as startups como um agenciamento permanente de elementos de diversas naturezas (LATOUR, 2012), conexão sem fim de $e+e+e \ldots$ mutações (DELEUZE; GUATTARI, 1995), cuja composição resulta das dinâmicas desses agentes em rede, relações sociais e circuitos comunicacionais, produzindo dessas relações uma infraestrutura empreendedora tecno-infocomunicativa, por meio do qual elas se produzem e, ao mesmo tempo, produzem a própria infraestrutura.

Tal perspectiva durante o caminho de pesquisa (que reconheço muito mais como uma postura) nos oferece a possibilidade de nos colocarmos atentos à participação das tecnologias digitais em sua natureza comunicativa e altamente produtiva, quando em sinergia com essas iniciativas de inovação. Nelas, os processos comunicativos permeiam de maneira abrangente o desenho dos seus modelos de negócios, assumindo muitas vezes o protagonismo em seus core business $^{30}$ : interfaces de conexão, plataformas de serviços e marketplace, SaaS (Software como Serviço), aplicativos.

\footnotetext{
${ }^{30}$ Da língua inglesa, core business refere-se à dimensão central de um negócio, definida em função da estratégia desse negócio para o mercado.
} 
Desde o surgimento das primeiras startups brasileiras na década de noventa - serviços de busca (Cadê, 1995), comparador de preços (Buscapé, 1999), lojas virtuais (Netshoes, 2000), os modelos de negócios na internet passaram por rápidas transformações. Com espaços wireless, big data, dispositivos, cloud computing, internet of things, ecossistemas comunicativos e inteligências em rede, as startups avançaram para modelos mais decentralizados, inteligentes e conectivos como: aplicativos de mobilidade e transporte, plataformas de serviços de compartilhamento, social networking e armazenamento. Nestas iniciativas, as ações infocomunicativas, a manipulação de dados, as trocas informativas, a circulação do conhecimento parecem assumir a qualidade que define essas startups. Hoje, são iniciativas como Uber, Airbnb, Dropbox, que viraram referências desse tipo de empreendedorismo e têm suas modelagens clonadas, melhoradas e/ou reinventadas ao redor no mundo.

Nessa direção, muito mais que uma ação humana de domínio dessas novas tecnologias como "recursos", parece-nos ocorrer uma relação de recursividade, não de pessoas apartadas das máquinas, mas de uma relação simbiótica onde, ao passo que essas tecnologias digitais são alteradas para atender as necessidades e/ou oportunidades de mercado identificadas por essas iniciativas empreendedoras, estas tecnologias acabam por alterar também os modos de empreender coisas, criando novas dinâmicas, novas modelagens, novas demandas, novos comportamentos e, sobretudo, apontando para uma qualidade relacional e comunicativa própria do contexto em que essas iniciativas estão inseridas e das próprias relações que elas estabelecem entre os elementos de diversas naturezas que as compõem.

Ao emergir de uma morfologia tecnosocial, estas práticas empreendedoras oferecemnos a possibilidade de pensar a qualidade das suas ações não centralizadas e deliberadas no e pelo humano, mas sim pensar em um agir que se dá pela coação, ou seja, uma ação em rede, entre elementos não unicamente humanos. A dimensão e abrangência que essas tecnologias comunicativas, inteligentes, conectadas e sensíveis ao ambiente assumem no empreendedorismo startup, atinge um nível de participação incapaz de escapar dos nossos olhos quando nos propomos a estudar este tipo de prática empreendedora. Ao se produzirem em uma complexidade de rede de redes, essas iniciativas nos abrem espaços férteis para pensá-las em uma ausência de externalidade, de domínio da ação por parte exclusiva do homem, e, sobretudo, na produção de um tipo de complexidade reticular capaz de considerar as relações dos elementos de diversas naturezas (DI FELICE; TORRES; YANAZE, 2012).

Esta percepção bem se adequa ao princípio de simetria extraído da Teoria Ator-rede (LATOUR, 2012), nos oferecendo como postura em nossas análises, a possibilidade de atribuir 
relevância semelhante e colocar na mesma hierarquia os diversos elementos que compõem a prática do empreendedorismo startup. Oferecendo, assim, um caminho para pensar a participação das tecnologias digitais nessas iniciativas em dimensões mais ampliadas, que ultrapassem a perspectiva de análise realizada na abordagem antropocêntrica e de instrumentalidade tecnológica percebida no trabalho de Ries (2012).

Se, outrora, o empreendedorismo praticado nas estruturas modernas e replicado no nosso contemporâneo baseia-se, essencialmente, nas relações de propriedade, no trabalho individual, na instrumentalidade tecnológica e nas relações com o capital e o gerenciamento, o tipo de empreendedorismo que emerge em uma lógica de rede de redes baseia-se nas relações de acesso, práticas cooperativas, no relacionamento, na tecnologia distribuída (RIFKIN, 2016; CASTELLS, 1999; BENKLER, 2006), e, sobretudo, em um tipo de inteligência que não se limita ao corpo social do empreendimento. Deslocando-se, assim, para a concepção de um tipo de ação coletiva e complexa no interior da qual os intelectuais coletivos são conectados, produzindo, dessa forma, um tipo de empreendedorismo cuja prática se realiza através da manipulação de dados, de um conjunto de interações entre os elementos de diversas naturezas e da concepção de uma tipo de produção social no interior da qual as inteligências e saberes convergem e se organizam por meio das tecnologias de informação e comunicação.

Uma outra contribuição valiosa ao conceito de startups é oferecida por Steve Blank (2014). Em verdade, é dele a atual noção mais aceita do conceito de startup. Segundo Blank, a startup pode ser compreendida como uma empresa em estágio inicial que está buscando um modelo de negócio que seja escalável e replicável. Com este conceito, ele põe em evidência a escalabilidade, reconhecida como importante característica que singulariza estas iniciativas de inovação de base tecnológica, conferindo-as a qualidade de produtoras de iniciativas portadoras da capacidade extrema e veloz de impactar muita gente. Este alto impacto é atribuído à base tecnológica dessas iniciativas, onde a potência produtiva dessas novas tecnologias permite o ganho de eficiência e reprodutibilidade em velocidade e níveis inéditos. Ao produzir-se imersa em uma infraestrutura inteligente em rede, oferecendo produtos e serviços digitais de dimensão essencialmente imaterial - bits, a startup de base tecnológica encontra nas redes a infraestrutura digital reprodutível para crescer sem uma demanda de recurso na mesma proporção, permitindo a reprodução em número quase ilimitado a um custo desprezível. 


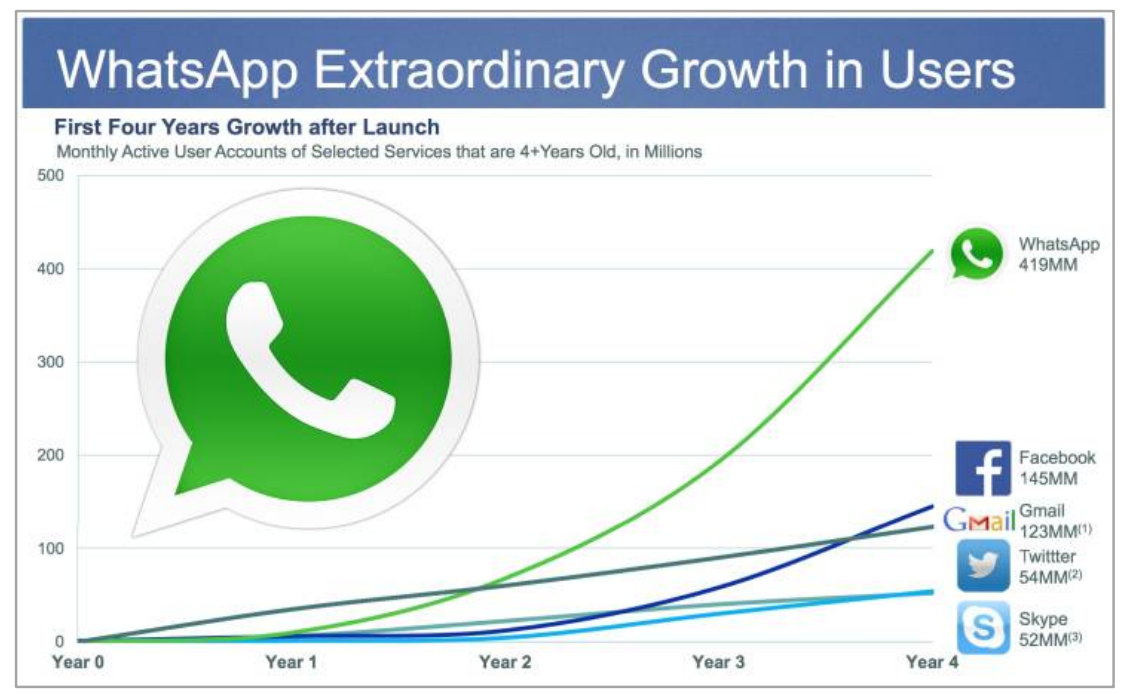

FIGURA 9. EXTRAORDINÁRIO CRESCIMENTO DO WHATSAPP: Comprado em 2014 pela maior rede popular do mundo, o Facebook, o serviço de mensagem instantânea gratuita multiplataforma para celular e smartphone, o WhatsApp Messenger, havia alcançado aproximadamente 500 milhões de usuários em (5) cinco anos com pouco mais de 50 pessoas em seu corpo social, provendo um serviço de grande impacto na comunicação entre as pessoas. Para apresentar escalas de crescimento como essas no mercado tradicional possivelmente as empresas tradicionais precisariam aumentar os seus recursos na proporção de expansão dos seus negócios, atendendo a exigências de uma cadeia produtiva com complexidade de dimensões física, estrutural, gerencial e estratégica que geraram as gigantes multinacionais desenvolvidas no último século $^{31}$

Extraída do conceito de produção em escala ou em massa, a escalabilidade ganha evidência no empreendedorismo startup ao conseguir impulsão nos níveis, custos e também na velocidade alcançada. A competência de alta difusão por meio de uma estrutura básica a todos alcança alta eficiência nos negócios digitais. Em verdade, para essas iniciativas, quanto mais eles avançam, mais barato seus negócios ficam, reduzindo os custos e ampliando margens de lucro. Mais que isso: estas startups agem tendo as arquiteturas informativas (DI FELICE, TORRES e YANAZE, 2012) como infraestrutura e o conhecimento como força produtiva incomensurável em circulação e conexões em rede. A potência coletiva de saberes e o conhecimento não objetivado, bem como a forma ágil de articulação, conferem a essas iniciativas o grande impacto e crescimento rápido que as singularizam.

\footnotetext{
${ }^{31}$ Imagem extraída do artigo Zuck Says Ads Aren't The Way To Monetize Messaging, WhatsApp Will Prioritize Growth Not Subscriptions publicado no Tec Crunch, Website de tecnologia. Disponível em: http://techcrunch.com/2014/02/19/whatsapp-will-monetize-later/ Acesso em 01 jun. 2016.
} 
Entretanto, não existe uma definição consensual sobre startup. No senso comum, sua definição é bastante diversa, usada também para fazer referência ao estágio, método, tamanho, cultura ou idade do empreendimento. A terminologia é usada, majoritariamente, como equivalência às iniciativas de tecnologia digital e inovação. Paul Graham, o empreendedor digital e co-fundador do Y Combinator, uma das maiores aceleradoras de startups do mundo, reconhece que:

[...] as startups geralmente envolvem tanta tecnologia que a frase 'startup high-tech' é quase redundante. A conexão entre startups e tecnologia é que startups criam novas maneiras de fazer as coisas, e novas formas de fazer as coisas são, no mais amplo sentido da palavra, a nova tecnologia. ${ }^{32}$

De fato, quando acompanhamos o fenômeno startup como um tema em escala e interesse global, estas startups em geral envolvem tecnologia, essencialmente tecnologia da informação e comunicação. A esse protagonismo da tecnologia da informação, Eduardo L'Hotellier, fundador e CEO da startup brasileira GetNinjas ${ }^{33}$, atribui às maiores escalas apresentadas pelos produtos de base tecnológica, que acabam por atingir mais pessoas e despertar maior curiosidade das pessoas e interesses dos investidores.

É mais comum ouvir na mídia startup de tecnologia, mas uma empresa de bioquímica que está desenvolvendo uma droga é uma startup, uma empresa que está desenvolvendo um novo modelo de franquia é uma startup. É mais uma questão que a gente escuta mais porque a mídia fala mais de produtos tecnológicos. Isso porque são produtos que em geral atingem mais pessoas e despertam mais a curiosidade dos leitores. A startup é uma empresa iniciante que está começando a empreender, então pode ser até nos mercados tradicionais, porque não necessariamente precisa ser tecnologia da informação - pode ser uma a tecnologia médica, robótica ou mercados tradicionais; pode ser um novo perfume, uma nova fragrância. Então, é mais o fato que se rouba o termo pelo uso repetitivo e pelas escalas dos produtos de tecnologia que são maiores. (informação verbal) ${ }^{34}$

Para Flávio Pripas, a tecnologia define as startups. O diretor executivo da Cubo Coworking, cofundador da startup de moda Fashion.me e da startup financeira descontinuada

\footnotetext{
32 Do original: "Startups usually involve technology so much so that the phrase "high-tech startup" is almost redundant. (...) The connection between startups and technology is that startups create new ways of doing things, and new ways of doing things are, in the broader sense of the word, new technology". Artigo publicado por Paul Graham em seu weblog. Disponível em: http://www.paulgraham.com/growth.html. Acesso em 27 jun. 2016.

${ }^{33}$ A startup GetNinjas é uma plataforma de serviços que será melhor detalhada nos capítulos seguintes. Seu sítio é: https://www.getninjas.com.br/. Acesso em 01. Jun. 2016.

34 Entrevista concedida por L'HOTELLIER, Eduardo fundador e CEO da plataforma de serviços GetNinjas. Entrevista II [jan. 2016]. Entrevistador: Ana Patrícia Santana. A entrevista na íntegra encontra-se transcrita no Apêndice B desta dissertação.
} 
Bitinvest, discorda do Sebrae (entidade privada sem fins lucrativos de fomento ao empreendedorismo) ao trabalhar o conceito de startup como "empresa iniciante". Para ele o conceito fundamental das startups está relacionado ao alto impacto que ela produz e com o poder em rede das tecnologias, promovendo alterações nos modos de fazer e viver.

$\mathrm{Na}$ minha concepção, startup é o que a gente chama de empresa de alto impacto, que é uma empresa que vai impactar a vida de muitas pessoas. A única forma de você impactar a vida de muitas pessoas é tendo tecnologia por trás. Ela precisa ser escalável. Porque, por exemplo, uma inovação, mas uma inovação só para atender esta cadeira que estamos sentados para mim não é uma startup. Agora se for mudar o modo de sentarmos em todas as cadeiras do mundo no meu ponto de vista é uma startup (informação verbal). ${ }^{35}$

Inseridas em uma perspectiva de criação de inovação e alto impacto, os potenciais de crescimento rápido e grande difusão têm sido essencialmente apontados como elementos fundamentais caracterizantes das startups. Rosi Rodrigues (2016), responsável durante quatro anos pela fundação e operação do programa de aceleração Startup Farm, cofundadora da startup para solução de pagamento online Iugu e conselheira da Associação Brasileira de Startups, ancora-se na sua experiência para definir a startup. Para ela, trata-se de um imbricado nas tecnologias, sendo esta a condição que confere às startups $o$ potencial de inovação e produção de alto impacto.

Pelo simples fato que o objetivo dela, o modelo de trabalho dela é dentro da escala operacional, dentro de algo que é escalável. E você só consegue fazer algo escalável com tecnologia, porque o princípio básico de escalar algo é que você consegue crescer. A startup cresce para cumprir este objetivo. O objetivo de ter o business escalável. Um outro conceito é a inovação. Ela está ligada à inovação. As inovações que as startups se propõem a fazer são inovações com impacto. Só que o impacto vem com tecnologia. A tecnologia te dá o 'como' você vai conseguir se expandir, se espalhar, como você vai consegui gerar lucro a curto prazo e ter uma boa margem. Para mim ela está extremamente conectada à base tecnológica e à inovação. (informação verbal) ${ }^{36}$

Segundo tipologia apresentada por Steve Blank (2011), os elementos apontados de alto impacto e alta escala caracterizariam as chamadas startups escaláveis, entendida por ele como um tipo de startup projetado para crescer rápido. Em seu artigo, ele nos apresenta mais cinco extratificações de categoria como segue: Lifestyle Startups (trabalhar para viver a sua paixão);

\footnotetext{
${ }^{35}$ Entrevista concedida por PRIPAS, Flávio. Diretor executivo do espaço co-working para startups Cubo. Entrevista I [jan. 2016]. Entrevistador: Ana Patrícia Santana. A entrevista na íntegra encontra-se transcrita no Apêndice A desta dissertação.

${ }^{36}$ Entrevista concedida por RODRIGUES, Rose. Diretora de operações da Associação Brasileira de startup, e cofundadora da startup IUGU. Entrevista IV [mar. 2016]. Entrevistador: Ana Patrícia Santana. A entrevista na íntegra encontra-se transcrita no Apêndice D desta dissertação.
} 
Small-Business Startups (trabalhar para alimentar a família); Buyable Startups (alvo de aquisições); Social Startups (fazer a diferença); Large-Company Startups (inovar ou evaporar).

Ancorada em uma base analítica simplista proposta por Blank (Ibidem), repousa na tipologia de startups escaláveis o grande volume de iniciativas de inovação, especialmente aquelas startups de produto e serviços digitais que têm protagonizado o fenômeno do crescimento das startups nos últimos anos. Com efeito, para o cumprimento dos objetivos desta pesquisa, nosso olhar está focado nessas startups. Interesse-nos as startups de base tecnológica que oferecem produtos e serviços digitais.

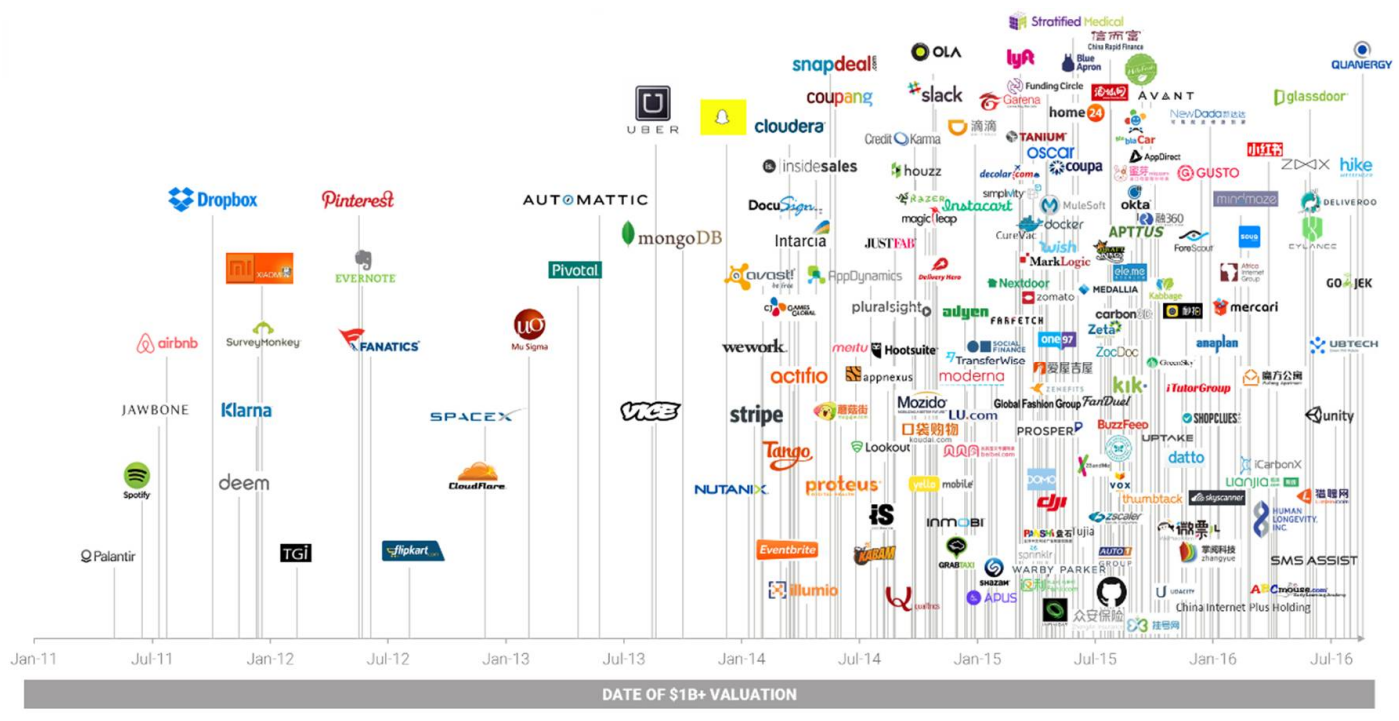

FIGURA 10. STARTUPS EXPONENCIAIS ${ }^{37}$

O crescimento exponencial das startups "unicórnios", empresas que atingem rapidamente avaliação de mil milhões de dólares ${ }^{38}$

\subsection{A ASCENSÃO}

"O custo de criação de uma empresa não é mais medido em milhões e sim no limite do seu cartão de credito $^{39}$ ". Em conferência proferida em Stanford University, Blank (2011) introduz sua análise sobre as mudanças dramáticas sofridas pelo empreendedorismo e o capital

\footnotetext{
${ }^{37}$ Imagem extraída do artigo 'The Crowded Unicorn Club In One Infographic', publicado em 26 ago. 2016. Disponível em: https://www.cbinsights.com/blog/increasingly-crowded-unicorn-club/. Acesso em: 01 set. 2016. ${ }^{38}$ Imagem extraída do artigo 'Gráfico mostra explosão impressionante no número de unicórnios mundialmente' Disponível no portal Starse: http://startse.infomoney.com.br/portal/2016/01/08/16008/grfico-mostra-explosoimpressionante-no-nmero-de-unicrnios-mundialmente/. Acesso em 01 jun. 2016.

${ }^{39}$ Fala de Steve Blank na 2011 Conference on Entrepreneurship realizada na Stanford University, intitulada The Democratization of Entrepreneurship. Disponível em https://www.youtube.com/watch?v=n-H7TAcqGko. Acesso em 19 dez. 2015
} 
de risco nas últimas décadas. Se até os anos noventa iniciar um negócio esbarrava em limitações como: altos custos iniciais, longo período para concepção do produto, longo período para conquistar consumidor, alto índices de insucesso, limitado número de capitalistas de risco e inovação limitada a algumas regiões, ele avalia que, nos últimos anos, quase todas essas limitações foram eliminadas de uma só vez.

As alterações no custo, tempo e alcance apontadas por ele parecem-nos apresentar uma inter-relação com as condições tecno-comunicativas em que essas iniciativas são pensadas e concebidas. A prática do empreendedorismo até então delimitada parece encontrar espaços que permitem o trânsito para uma prática empreendedora que opera em redes, assumindo esta a morfologia-rede. Por acontecerem em uma espacialidade e em uma arquitetura comunicativa outra, essas práticas trazem em si a qualidade do acesso, a natureza distribuída, a ampliação das relações sociais de cooperação, bem como o protagonismo do conhecimento e da comunicação.

Nessa ambiência em fluxos de redes, as práticas apresentam uma transformação qualitativa que permeia a engenharia, a inteligência, a cultura e as próprias dinâmicas dessas iniciativas. A rede de redes como espaços férteis de inovação e como infraestrutura inteligente que conecta tudo e todos, acaba por produzir uma massa de cooperação que, articulada com o conhecimento, passa a orquestrar novas formas de participação do conhecimento e de participação das pessoas na criação de valor e inovação.

Dentre as simultâneas transformações citadas por Blank (2011), uma mudança significativa sentida pelo empreendedorismo é a ampliação do acesso a suas práticas, alcançada, em grande medida, pela exigência de pouco capital para teste e validação do modelo de negócio em rede. Hoje, com códigos livres, integrações facilitadas, interfaces de programação e ausência de hardware, somados a produções distribuídas e comportamentos de cooperação, o custo para produzir o primeiro produto ou serviço foi minimizado.

No paradigma da sociedade em rede, o acesso global a usuários e consumidores impacta profundamente a dinâmica de concepção dessas startups. Distante de se obter um serviço ou produto acabado como fruto de um plano rígido respeitosamente seguido, a ideia de produto ou serviço, uma vez prototipada e inacabada, queima todas as longas fases de planejamento e incubação e são testadas e validadas por sujeitos em rede, em um processo instantâneo, dinâmico, flexível e continuado de experimentação.

No interior de infraestruturas "tecno-infocomunicativas", o processo isolado de concepção, somados as preocupações com propriedade intelectual, as intensivas relações de capital e domínios dos meios de produção perdem espaços para um processo de concepção 
reticular, resultante de um tecimento plural de conhecimento e experimentações, para atender uma dinâmica participativa e a uma demanda incerta e sujeita a acontecimentos.

Assim, esse tipo de empreendedorismo que nasce desse ecossistema comunicativo se produz em uma nova dinâmica onde os riscos de falha são minimizados, ampliando consequentemente as ofertas de investimentos, as chances de sucesso e alcance global dessas iniciativas. Nesta direção, a prática deste empreendedorismo até então restrita a algumas regiões e limitada a grandes investimentos iniciais e ao risco, encontra nas redes inteligentes distribuídas e na cooperação produtiva, condições para desenvolver-se e disseminar-se, deixando de ser um tipo de empreendedorismo restrito aos tradicionais polos tecnológicos e nichos empresarias.

Com isso, o empreendedorismo startup, que encontrou inicialmente terreno fértil no Silicon Valley na década de noventa, encontrou também, no fluxo das redes, caminhos para desenvolve-se rapidamente nas principais capitais do mundo, assumindo uma nova geografia, em que o capital e a competência produtiva se tornam acessíveis. Isto altera a mecânica, as articulações e as relações de competitividade desse tipo de empreendedorismo.

Embora as primeiras startups de base tecnológica brasileiras tenham surgido a partir da segunda metade da década de noventa, estas iniciativas começaram a ganhar volume e relevância nos últimos anos. Segundo o StartupBase, banco de dados oficial das startups no Brasil e integrado à Associação Brasileira de Startups ${ }^{40}$ (ABStartup), são 4.162 mil startups cadastradas no país, com modelos de negócios, principalmente na criação de produtos e serviços do tipo B2B (oferece serviços para outras empresas) ${ }^{41}$, com (884) startups registradas, seguidos do mercado do tipo B2C (transação entre empresa e consumidor final), que registra (634) startups e serviços de assinaturas com (463) startups cadastradas.

\footnotetext{
${ }^{40}$ Criada em 2011 a ABStartup é uma entidade sem fins lucrativos que visa promover o ecossistema brasileiro de startups. Os dados foram coletados do seu banco de dados oficial Startupbase. Disponível em: Ver: http://startupbase.abstartups.com.br/startups. Acesso em 09 jul. 2016.

${ }^{41}$ Segundo estudo 'Panorama das Startups no Brasil' divulgado em 2016 pela aceleradora Startup Farm, a partir de 2014, apenas $21 \%$ das startups focavam em B2C, contra $64 \%$ em B2B. A escolha pelo modelo B2B então continuou em 2015, com 38\% das startups adotando esse modelo, contra 27\%, e em 2016 - 50\% (B2B) e 14\% (B2C). Disponível em: http://blog.startupfarm.com.br/tag/b2b/ . Acesso em: 16 Ago. 2016.
} 

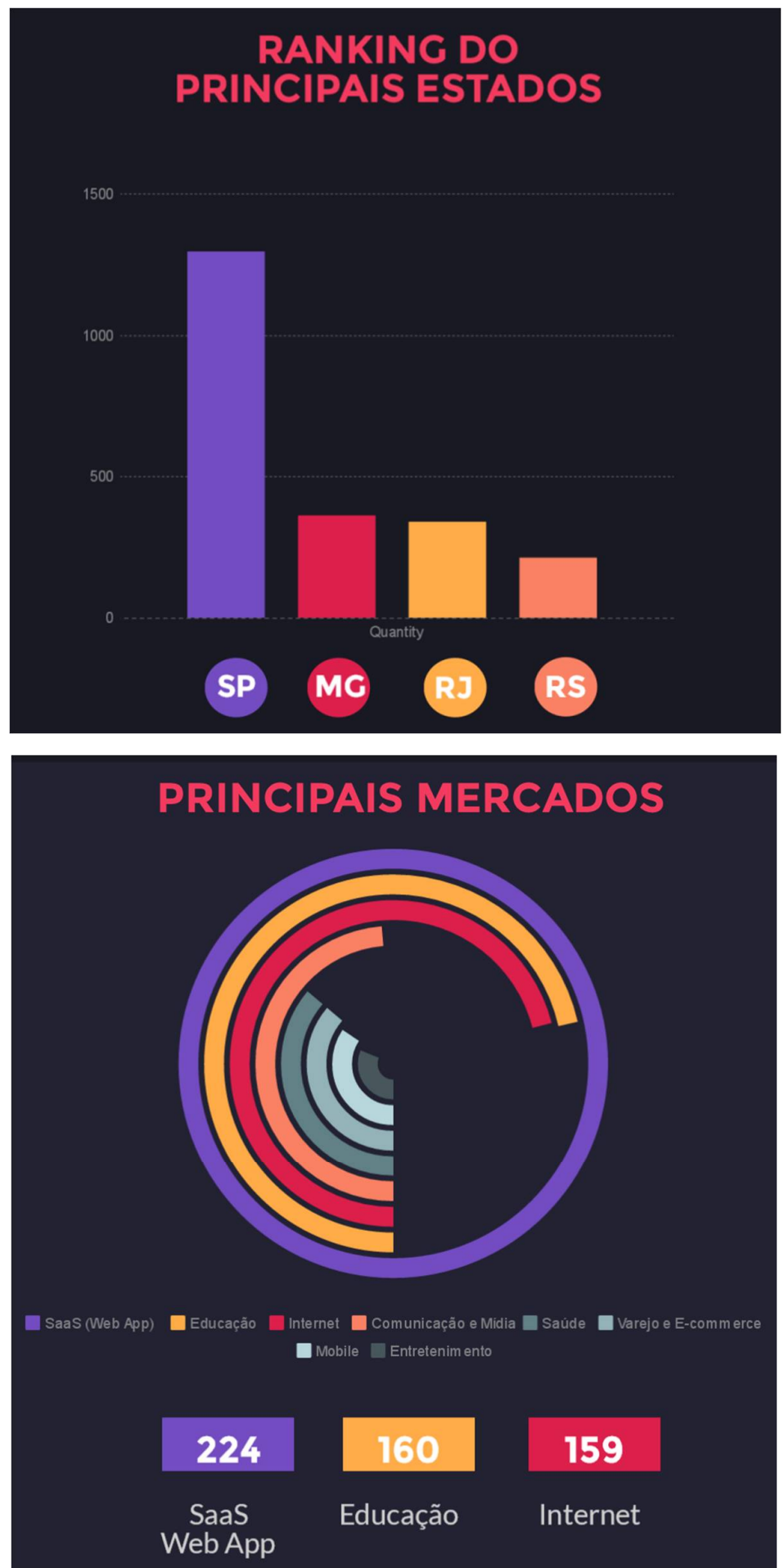

FIGURA 11. OS NÚMEROS DAS STARTUPS BRASILEIRAS ${ }^{42}$

O estado de São Paulo lidera o número de startups no país, seguido dos estados de Minas Gerais e Rio de Janeiro. Seu principal mercado é o de desenvolvimento de aplicativos, seguido dos mercados de educação e Internet.

42 Elaborado pela autora. Informações extraídas do banco de dados oficial das startups, Startupbase. Disponível em: Ver: http://startupbase.abstartups.com.br/startups. Acesso em 09 jul. 2016. 
No Brasil há um índice acentuado de mortalidade das startups. O estudo realizado pela Fundação Dom Cabral $^{43}$, que objetivou compreender o fenômeno de descontinuidade das startups no País, aponta que uma em cada quatro startups morrem antes de completar o seu primeiro ano de vida. Segundo a pesquisa, ao assumirem o risco de inovação desde a sua concepção, as startups não só apresentam características próprias como também enfrentam desafios bastante particulares para chegarem e se manterem no mercado. Este cenário acaba por também evidenciar a relevância de estudos que contribuam para desvelar esse novo tipo de empreendedorismo e explorar as singularidades deste fenômeno ainda incipiente no país.

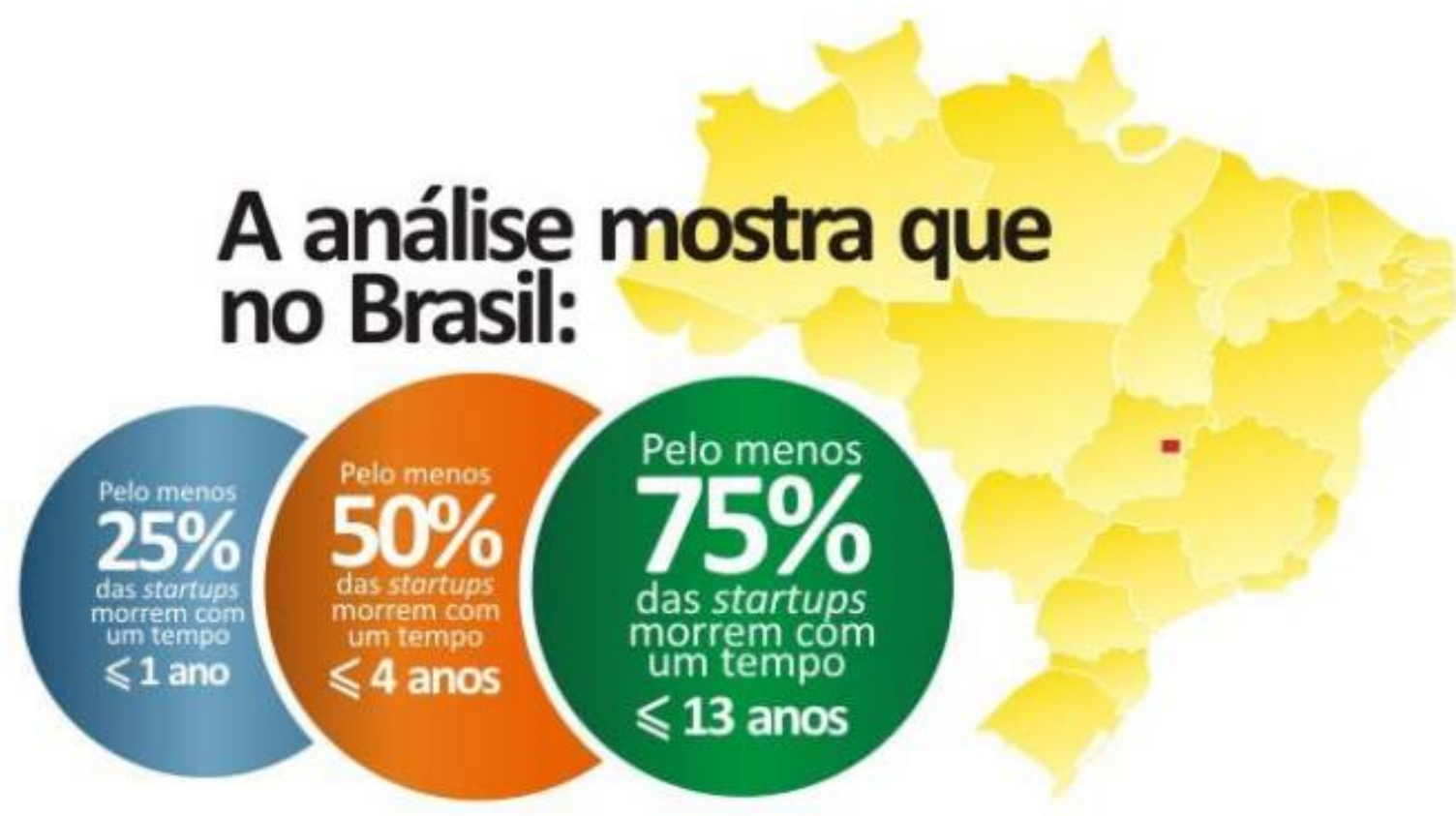

FIGURA 12. MORTALIDADE DAS STARTUPS NO BRASIL

Estudo realizado pela Fundação do Cabral revela alto índice de descontinuidade das startups brasileiras, em seu primeiro ano de vida ${ }^{44}$.

\footnotetext{
${ }^{43}$ A pesquisa é intitulada Causas da Mortalidade de Startups Brasileiras: O que fazer para aumentar as chances de sobrevivência no mercado? Foram coletados dados quantitativos por meio de um questionário online enviado a fundadores e cofundadores de startups no Brasil. A pesquisa totalizou uma amostra de 221 questionários respondidos, sendo que 130 foram de empresas ainda em operação e 91 de empresas descontinuadas. A amostra foi dividida em dois perfis de respondentes sendo: (1) Fundadores de startups brasileiras que tiveram suas startups descontinuadas e (2) Fundadores de startups brasileiras que ainda estão atuando no mercado. Disponível em: https://www.fdc.org.br/blogespacodialogo/Documents/2014/causas_mortalidade_startups_brasileiras.pdf. Acesso em: 01 jun. 2016.

${ }^{44}$ Idem.
} 


\subsection{O ECOSSISTEMA}

O ecossistema de startup funciona como uma metáfora que faz referência ao conjunto de agentes que contribuem para a construção de um ambiente favorável ao desenvolvimento do emprendedorismo startup, como: aceleradoras, espaços coworking, startups, universidades, hubs, grandes corporações, investidores-anjos, venture capital, entre outros (FELD, 2012; HWANG, 2012). Embora referenciado com bastante frequência nas ambiências startup, a noção de ecossistema como metáfora para promover o empreendedorismo aparece em estudos mais tradicionais do campo.

Com o Babson Entrepreneurship Ecosystem Project ${ }^{45}$, projeto global de pesquisa em ação sobre o empreendedorismo, o professor americano da Babson College, referência mundial no estudo da área, Daniel Isenberg (2011), nos apesenta o "ecossistema de empreendedorismo", entendido por ele como um conjunto de elementos individuais - tais como liderança, cultura, mercados de capitais e clientes abertos - que se combinam de forma complexa na promoção da ação empreendedora (ISENBERG, 2010) . Como pode ser observado na Figura 13, com a apresentação de um diagrama que agrupa em (6) seis domínios gerais os diversos elementos que compõem o ecossistema de empreendedorismo - mercados, política, finanças, cultura, capital humano, suporte, ele pretende definir a dinâmica e as relações de interdependência entre diferentes tipos de atores organizados com a finalidade de fomentar a atividade empreendedora. Com a representação, Isenberg pretende obter um mapa claro do que o ecossistema inteiro se parece, permitindo a formação de ecossistemas em torno de condições locais.

Hoje, quando caminhamos para o entendimento daquilo que é referenciado como ecossistema startup, percebemos um conjunto de redes dentro de redes em um tecido de conexões e relações, suscitando uma tipo de organização e dinâmica outras. Concebido como uma complexidade sistêmica, a abordagem externa e frontal do ecossistema de empreendedorismo parece não dar conta da abrangência e qualidade das relações presentes no ecossistema startup, não passível de observação holística e visualização total dos conjuntos de redes que o compõe. (DI FELICE; TORRES e YANAZE, 2012).

Assim, parece-nos que para nos aproximarmos de um entendimento do ecossistema de startups (ver Figura 14), precisamos entender as redes de relações que compõem esse

45 O projeto global 'Babson Entrepreneurship Ecosystem Project' está disponível em: http://www.babson.edu/executive-education/custom-programs/entrepreneurship/Pages/entrepreneurshipecosystem.aspx. Acesso em 01. Jun. 2016. 
ecossistema comunicativo, disperso e com múltiplas entradas e múltiplas saídas - uma dinâmica e organização que parecem escapar da complexidade sistêmica do ecossistema empreendedor, insuficiente para explicar a dinâmica complexa relacional, expressão no empreendedorismo que se realiza em rede de redes. "Entender ecossistemas será, em última análise, entender redes." Assinala Capra (2001, p. 82).

\section{BABSON Domains of the Entrepreneurship Ecosystem}

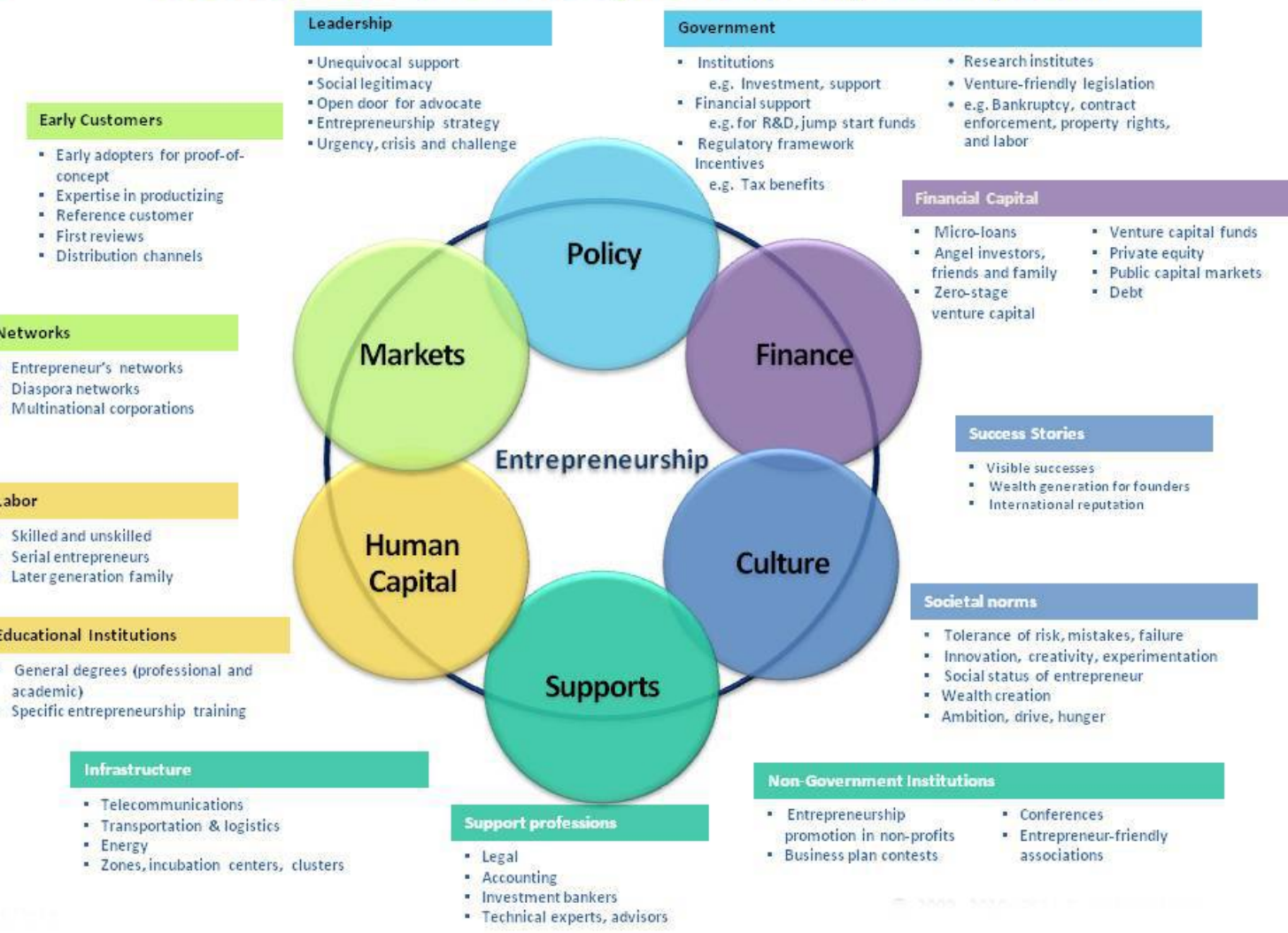

FIGURA 13. O ECOSSISTEMA EMPREENDEDOR

Segundo o modelo, esses domínios se reforçam mutualmente por meio de interações complexas entre os diversos elementos que os compõem e a natureza interconectada dos elementos dos ecossistema ${ }^{46}$.

46 Uma adaptação do modelo desenvolvido por Daniel Isenberg(2011) disponível em http://entrepreneurialrevolution.com/view-the-ecosystem-diagram/ Acesso em 01. Mai. 2016. 


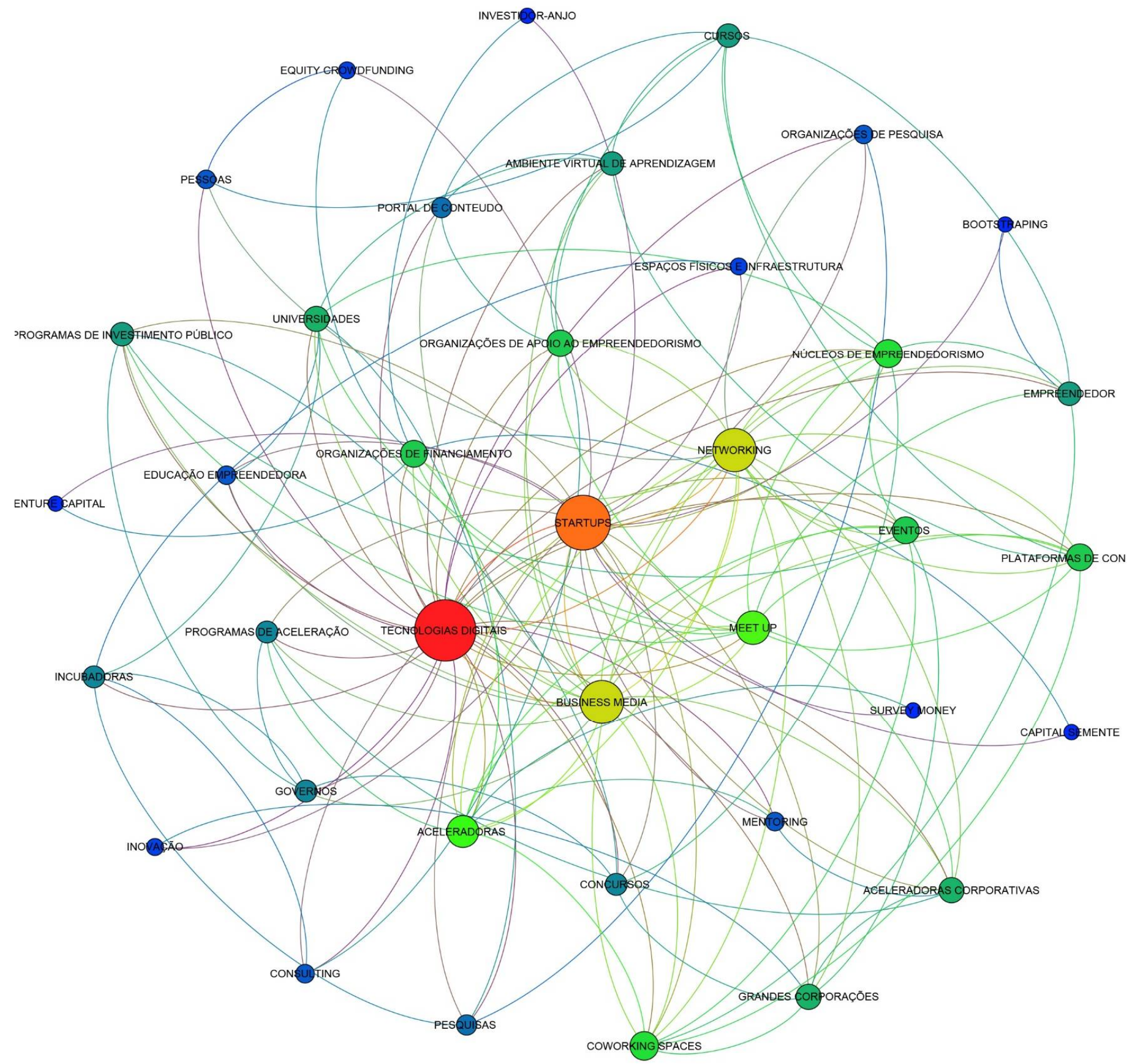

FIGURA 14. O ECOSSISTEMA DE STARTUPS DIGITAIS ${ }^{47}$

Representação elaborada pela autora corresponde ao conjunto de redes que se interacionam para o tecimento de um ambiente favorável ao desenvolvimento do emprendedorismo startups, como: aceleradoras, espaços coworking, startups, universidades, venture capital, entre outros.

${ }^{47}$ Elaborado pela autora 
Segundo o relatório internacional Global Startup Ecosystem Ranking 2015 (COMPASS, 2015), a cidade de São Paulo é o melhor ecossistema para a criação de startups de tecnologia da América Latina. O estudo que mapeou e classificou os vinte maiores ambiências de startup em todo o mundo, apresenta a cidade de São Paulo como o único ecossistema da América Latina no ranking global e apresenta o terceiro mais rápido índice de crescimento $(3,5)$ dos vinte ecossistemas avaliados. Muito embora as redes digitais propiciem um ecossistema em escala global, existem estudos que apontam a densidade como um dos fatores-chave de se ter um ecossistema de startup de tecnologia que se desenvolva, demonstrando que o ecossistema de startup local cria densidade de pessoas, de ideias e de oportunidades, gerando melhores e maiores experiências de startups (FELD, 2012; UP GLOBAL, 2014)

\begin{tabular}{|c|c|c|c|c|c|c|c|c|}
\hline & Ranking & & Performance & Funding & Market Reach & Talent & Startup Exp. & Growth Index \\
\hline Silicon Valley & 1 & 4 & 1 & 1 & 4 & 1 & 1 & 2.1 \\
\hline New York City & 2 & $\Delta 3$ & 2 & 2 & 1 & 9 & 4 & 1.8 \\
\hline Los Angeles & 3 & 4 & 4 & 4 & 2 & 10 & 5 & 1.8 \\
\hline Boston & 4 & $\Delta 2$ & 3 & 3 & 7 & 12 & 7 & 2.7 \\
\hline Tel Aviv & 5 & -3 & 6 & 5 & 13 & 3 & 6 & 2.9 \\
\hline London & 6 & $\Delta 1$ & 5 & 10 & 3 & 7 & 13 & 3.3 \\
\hline Chicago & 7 & -3 & 8 & 12 & 5 & 11 & 14 & 2.8 \\
\hline Seattle & 8 & -4 & 12 & 11 & 12 & 4 & 3 & 2.1 \\
\hline Berlin & 9 & -6 & 7 & 8 & 19 & 8 & 8 & 10 \\
\hline Singapore & 10 & $\Delta 7$ & 11 & 9 & 9 & 20 & 9 & 1.9 \\
\hline Paris & 11 & 4 & 13 & 13 & 6 & 16 & 15 & 1.3 \\
\hline Sao Paulo & 12 & $\Delta-1$ & 9 & 7 & 11 & 19 & 19 & 3.5 \\
\hline Moscow & 13 & $\Delta-1$ & 17 & 15 & 8 & 2 & 20 & 1.0 \\
\hline Austin & 14 & NEW & 16 & 14 & 18 & 5 & 2 & 1.9 \\
\hline Bangalore & 15 & $\Delta 4$ & 10 & 6 & 20 & 17 & 12 & 4.9 \\
\hline Sydney & 16 & -4 & 20 & 16 & 17 & 6 & 10 & 1.1 \\
\hline Toronto & 17 & -9 & 14 & 18 & 14 & 15 & 18 & 1.3 \\
\hline Vancouver & 18 & -9 & 18 & 19 & 15 & 14 & 11 & 1.2 \\
\hline Amsterdam & 19 & NEW & 15 & 20 & 10 & 18 & 16 & 3.0 \\
\hline Montreal & 20 & NEW & 19 & 17 & 16 & 13 & 17 & 1.5 \\
\hline
\end{tabular}

FIGURA 15 RANKING GLOBAL DE ECOSSISTEMA DE STARTUPS

No contexto global, São Paulo aparece na $12^{\mathrm{a}}$ posição, sendo a única cidade da América Latina no ranking. O estudo avaliou as cidades segundo cinco critérios: performance, investimento, talento, alcance de mercado e experiência ${ }^{48}$

\footnotetext{
${ }^{48}$ Imagem extraída do estudo global realizado pela Compass. Disponível em: http://blog.compass.co/the-2015global-startup-ecosystem-ranking-is-live/. Acesso em: 01 Jun. 2016.
} 


\subsection{O CICLO}

O ciclo das startups sugerido pelos estudos de Steve Blank ${ }^{49}$ nos apresenta de maneira simplificada o ciclo percorrido pelas startups, fazendo referências diretas ao estudo da metodologia customer development ou desenvolvimento de clientes. Esta metodologia foi também criada por ele e apresentada na obra Startup: Manual do Empreendedor (2014) com coautoria de Bob Dorf. Neste ciclo, Blank nos apresenta três etapas como segue:

- Busca (Search): corresponde ao estágio em que a startup procura pelo produto e pelo mercado ideal. Neste estágio ela conta com um número pequeno de pessoas e se organiza através de pouco ou nenhum processo, onde suas atividades são realizadas sem divisões de atribuições ou definiçõoes claras. Se faz aquilo que precisa ser feito. Este estágio finda com a validação do produto por parte do consumidor.

- Construção (Build): estágio subsequente em que a startup ganha escala através do crescimento de clientes/usuários/pagantes com uma taxa de crescimento que a permita alcançar um fluxo de caixa positivo e/ou gerar usuários em uma taxa que permita a monetização. É uma fase em que a startup precisa implementar sua cultura, estruturar seus processos, criar procedimentos, construir planos e controles.

- Crescimento (Grow): estágio em que a startup atinge liquidez e cresce através de processos reprodutíveis.

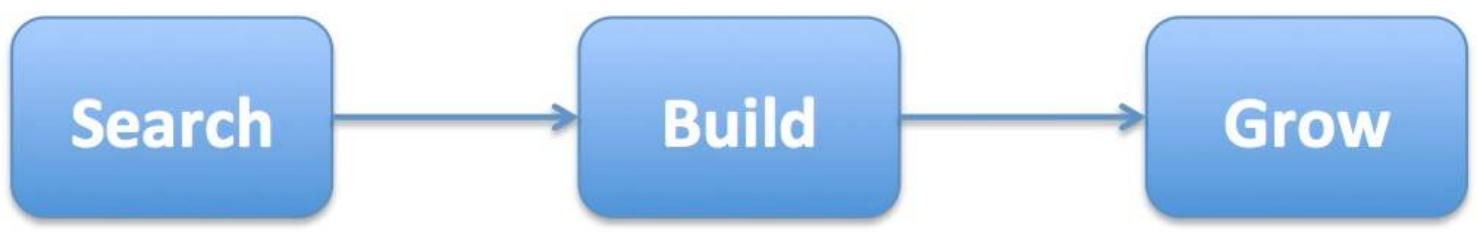

Figura 16 Ciclo de VIDA DAS STARTUPS POR STEVE BLANK ${ }^{50}$

\footnotetext{
49 Publicação no blog. Disponível em: https://steveblank.files.wordpress.com/2015/02/search-build-grow.jpg Acesso em 14 mai. 2016

${ }^{50}$ Imagem extraída do blog de Steve Blank. Disponível em: https://steveblank.com/2015/02/12/what-do-i-do-now/ Acesso em 14 mai. 2016
} 
Embora não haja um consenso quanto ao ciclo de vida das startups e seja possível encontrar algumas variações em blogs, sites especializados e na própria fala dos agentes do ecossistema startup, em grande medida, o que observamos é que estes modelos em suas variações recorrem às etapas presentes no estudo de Desenvolvimento de Clientes (BLANK e DORF, 2014) para descrever e até mesmo nomear as suas etapas. Blank (2015) também realiza esta relação, imbricando as próprias etapas de sua metodologia para desenvolver o seu modelo de ciclo das startups.

O desenvolvimento de clientes, ou customer development, explorado por Steve Blank e Dorft (2014), consiste em um processo interativo de criação de empresas com foco no aprendizado e na aproximação do cliente na busca por um modelo de negócio. O método oferece um conjunto de ações para descoberta do mercado, identificação dos clientes e validação das hipóteses fundamentais do negócio, por meio de interação constante entre as startups e clientes de forma ágil e com flexibilidade para ajustes e correção imediatas ao longo do processo. Partindo do pressuposto de que existe um caminho recorrente que as startups podem seguir para minimizar a ocorrência de fracassos, nessa obra os autores realizam um esforço para mapear esse caminho e oferecer às startups alguns princípios e processos que as auxiliem no seu percurso de busca, por um modelo de negócio repetível e escalável.

$\mathrm{Na}$ publicação anterior, The four Steps to the epiphany (2006), Blank aponta as limitações do modelo tradicional de criação de empresas, sobretudo quando o modelo é adotado pelas startups. Para ele, estas não são versões menores de grandes empresas e seu contexto difere das empresas já estabelecidas. Uma startup está em busca de um modelo de negócio, geralmente em um mercado novo, desconhecido, sem um produto ainda definido. Logo, está em busca de um modelo de negócio e não na execução desse modelo. Por isso o autor defende que o modelo tradicional, the product development model (modelo de desenvolvimento de produto), não é o mais adequando para as startups. Em seu momento de aprendizado e descobertas, as startups precisam de maior flexibilidade e interação com o cliente e em seus processos.

Assim, o modelo tradicional de desenvolvimento de produto adotado por empresas já estabelecidas e presente como matéria do currículo das escolas com formação em negócios prevê fases detalhadas e uma sequência de eventos. Nele, as empresas executam um planejamento minucioso, com exposições cadenciadas e pontos de checagem de meta até chegar ao lançamento de produtos acabados, momento este em que os subsídios dos feedback de clientes e mercados são de fato recebidos. Segundo Blank (2006), aqui está a causa essencial do alto índice de fracassos das startups. A adoção do modelo tradicional de criação de empresas 
nas startups amplia a mortalidade destas, pois o modelo não oferece a flexibilidade necessária ao aprendizado e às descobertas que elas exigem.

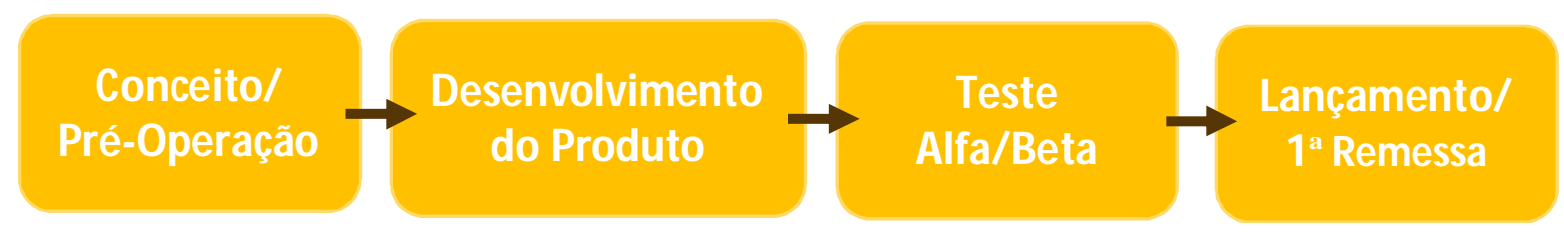

Figura 17. DIAGRAMA DE LANÇAMENTO DE NOVO PRODUTO ${ }^{51}$

O diagrama de lançamento de novo produto oferece instrumentos apropriados para executar negócios conhecidos, seguindo um rígido processo de gestão e lançamento de produto. Entretanto, estas ações isoladas produzem resultados desastrosos para iniciativas com alto nível de inovação.

Em contraste, o desenvolvimento de clientes, ou the customer development model, se propõe a oferecer um modelo que se adapta melhor às startups e torna menos arriscado o processo de criação de uma empresa, reduzindo as taxas de insucessos desses novos empreendimentos. As startups, como iniciativas que lidam com o desconhecido e a experimentação de novos caminhos, encontram, no novo método, processos que permitem a adaptação ágil e a flexibilidade de ação que os próprios canais e produtos (bits) dessas iniciativas oferecem. No desenvolvimento de clientes, os processos são organizados em feedback sobre o produto, canal, preço e posicionamento. Isto permite a modificação e testes praticamente em tempo real para ajustes, reformulações e otimizações.

O método organiza a busca pelo modelo de negócio, permitindo às startups moveremse no "ritmo Internet" e organizar a busca por respostas que promovam a obtenção de um modelo de negócio recorrente (BLANK; DORFT, 2014, p. xiv). Para isso, ele coloca os seus fundadores diante do cliente desde o primeiro momento e, frequentemente, em oposição ao processo que tangencia essa relação. A execução dos planos de negócios que preveem a operação na surdina e o lançamento dos produtos totalmente acabados está sendo substituída por ações em que jovens empreendimentos testam hipóteses, buscando cedo a opinião dos

\footnotetext{
${ }^{51}$ Adaptação de imagem extraída da obra The four Steps to the epiphany (BLANK, 2006, p. 2).
} 
clientes (e com frequência) e apresentando um produto mínimo viável ${ }^{52}$ aos interessados. $(\mathrm{BANK}, 2013)^{53}$.

A criação de empresas por meio do método de desenvolvimento de clientes apresenta quatro etapas iterativas principais agrupadas em duas fases: a fase de aprendizado e a fase de execução, que devem ser repetidas quantas vezes forem necessárias até a startup encontrar condições para avançar em seu desenvolvimento. A primeira fase, que corresponde à procura do negócio, apresenta duas etapas:

- Customer Discovery (descoberta com o cliente): concepção e alinhamento do produto e solução para testes;

- Customer Validation (validação com o cliente): projeção e validação do modelo de negócio.

Já na segunda fase, o estágio de execução, encontramos as etapas de:

- Customer Creation (criação com o cliente): encontro de mercado, clientes e modelo financeiro

- Company Bulding (construção da empresa): o fim da transição do foco no aprendizado para o foco na execução, tendo como desafio o crescimento, o grande público e a evolução das estratégias gerenciais.
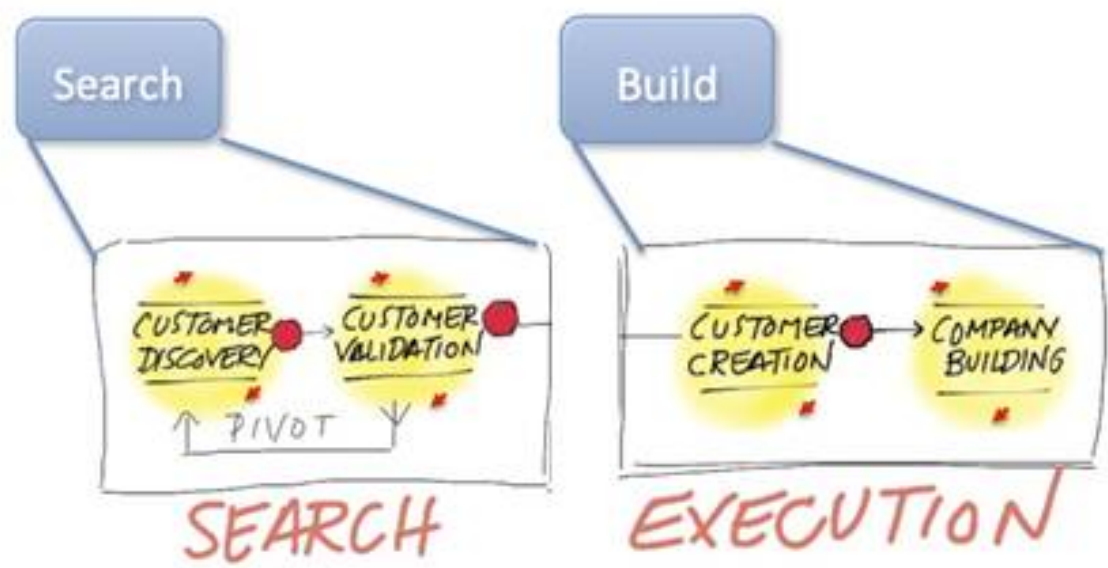

FIGURA 18: DESENVOL VIMENTO DE CLIENTES E O CICLO DAS STARTUPS ${ }^{54}$

\footnotetext{
52 Na metodologia Lean Statup, popularizada por Eric Ries (2012), o produto mínimo viável, do Inglês Minimum Viable Product, corresponde a um marco importante no ciclo de vida de um empreendimento. Apresentado no menor tamanho possível e entregue também no menor tempo possível, o PMV caracteriza-se também por reunir a proposição de valor suficiente e funcionalidades semelhante a um produto coeso.

53 Artigo online na revista Harvard Business Review. Disponível em: http://hbrbr.com.br/por-que-o-movimentolean-startup-muda-tudo/. Acesso em: 13 mai. 2016.

54 Imagem extraída de postagem no do blog de Steve Blank. Disponível em: https://steveblank.files.wordpress.com/2015/02/search-build-grow.jpg. Acesso em 14 mai. 2016
} 


\section{AS STARTUPS: FENÔMENO DA IMATERIALIDADE}

A pesquisa avançou tendo como base teórica os pressupostos do trabalho imaterial, ou seja, o trabalho intelectualizado e cada vez mais dependente de elementos linguísticos, cognitivos e afetivos. Pressupostos que não apontam para uma ruptura social, mas para uma mudança profunda nas relações de produção. Apresentamos também como aporte teórico a cooperação como a grande sistemática do trabalho e como dispositivo fundamental das criações das startups. Um conjunto geral de potências produtivas de sujeitos em ação onde trabalhar é produzir-se. Com efeito, a pesquisa insere-se em um contexto em que o conhecimento desponta como principal força produtiva, provocando uma mobilização total, o advento do autoempreendedor e a vida como business, conforme Gorz (2005) nos projeta.

Entender as transformações sofridas no exercício da atividade econômica contemporânea perpassa pela construção de relações de aproximação com as transformações também sofridas pelas arquiteturas comunicativas e sociais com o advento das tecnologias digitais. Estas são teias do complexo ecossistema da sociedade-rede, agentes vivos das novas arquiteturas comunicativas. Distante de obedecer a uma lógica unidirecional, hoje as informações se apresentam em fluxos e em redes, estabelecendo uma comunicação dialógica e ampliando de maneira inédita os processos de participação coletiva (DI FELICE, 2008). Essa condição permite que as pessoas interajam economicamente umas com as outras e se conectem na criação de novas relações sociais de produção, de novos arranjos econômicos e de cooperação (GORZ, 2005; BENKLER, 2006; ABRAMOWAY, 2012; RIFKIN, 2016).

Para Milton Santos (2000), trata-se de um momento histórico em que a humanidade dispõe de condições científicas e técnicas inéditas para moldar os modos de vida econômicos e participar dos seus processos em níveis sem precedentes em nossa história. Desse contexto extraordinário é possível observar a emergência de modelos diversos de articulação da vida econômica, orquestrados a partir da exploração de uma condição contemporânea de intensa participação das tecnologias digitais e seus potenciais produtivos (escalabilidade) e comunicativos (ação em ecossistemas) no exercício de atividades sociais e econômicas. Produções mesmo de uma sociedade que cada vez mais se organiza em uma lógica de rede de redes.

Um dos fenômenos deste contexto - entre tantos outros observados - ocorre com o empreendedorismo startup - um processo emergente do 'mundo-rede', um fenômeno que se 
produz, essencialmente, pela hegemonização do comando de máquinas, pela cooperação e pela produção de sapiência de sujeitos que De Kerckhove (2009) chama de inteligências conectivas, e Lévy (1998) de inteligência coletiva, e aqui temos uma preferência pelo conceito de Negri (2003) de uma inteligência geral como uma junção comum de uma multiplicidade de sujeitos.

São muitas as construções teóricas produzidas que, em seus divergentes, diferentes e/ou complementares percursos e perspectivas, refletem a pluralidade dos esforços realizados na tentativa de explicar as mudanças rápidas, estruturais e desestabilizantes ocorridas no interior da economia contemporânea: Economia do conhecimento (GoRZ, 2005); Economia em Rede (BENKLER, 2006), Economia Cognitiva (LÉVY, 1998), Economia Pós-Gutemberg (SHIRKLEY, 2011), Economia digital (TAPSCOTT, 2007); Economia Informacional (CASTELLS, 1999); Economia da abundância (RIFKIN, 2016); Economia Peer to Peer (BAWENS \& KOSTAKIS, 2014); Economia da Informação (SHAPIRO; VARIAN, 2003).

No cerne dessas construções teóricas estão os efeitos de um potencial tecnológico alicerçado na tecnologia da informação e da comunicação. Trata-se de um novo paradigma tecnológico que, segundo Castells (1999), caracteriza-se pela ocorrência de uma arquitetura em rede, pelo uso de uma linguagem digital comum e pela velocidade de progresso, uso e disseminação de suas inovações. Ao orquestrar seus pensamentos sobre a economia contemporânea - em suas limitações, potencialidades, transformações e hibridações, estes teóricos atribuem à comunicação (ou seja, à linguagem) uma das bases fundamentais na articulação de uma nova perspectiva do pensamento econômico. Uma perspectiva cuja característica marcante é exatamente a presença desta arquitetura informativa, descentralizada e cognitiva, capaz de promover alterações na maneira como produzimos, consumimos, trabalhamos, capitalizamos, nos organizamos e, em sentido mais amplo, capaz de promover alterações na maneira como pensamos a relação entre o capital e a vida.

O movimento desses teóricos de buscar entender as transformações econômicas através de uma estreita aproximação com as formas comunicativas não é algo novo, remetendo-nos ao estudo realizado em 1950 por Harold Innis na publicação Empire and Communication, em que o teórico realiza um percurso histórico de como os meios de comunicação influenciaram a ascensão e queda de quatro impérios ao longo da história - Egito, Grécia, Império Romano e Babilônia, e postula que algumas das razões da ascensão e queda dessas estruturas econômicas estão, em grande medida, vinculadas com a estrutura comunicativa usada nesses impérios.

O sociólogo espanhol Manuel Castells (1999) apresenta um estudo aprofundado sobre os processos de transformação tecnológica nos âmbitos comunicativo, social e econômico, definindo tal transformação como uma 'revolução' e demonstrando estas mudanças como mais 
um passo no desenvolvimento secular do capitalismo. Para ele, o grande potencial de criar interfaces entre campos mediante essa linguagem digital comum, na qual a informação é gerada, armazenada, recuperada e transmitida, representa no mínimo, um evento histórico da mesma importância da Revolução Industrial do século XVIII, ao induzir um padrão de descontinuidade nas bases materiais da economia, da sociedade e da cultura.

O economista Jeremy Rifkin (2012) reconhece, nessa onda de transformações, dimensões ainda mais ampliadas e anuncia uma Terceira Revolução Industrial em curso, onde atribui às arquiteturas comunicativas descentralizadas uma das bases para construção de uma unidade que nos conduzirá a uma nova fase econômica. Para ele, vivemos em um interregno entre dois períodos da história econômica - o primeiro caracterizado pelo comportamento industrioso, produtivo, e o segundo pelo comportamento colaborativo, responsável por fazer emergir contrapoderes que operam por meio das redes digitais e escapam das relações de controle. Segundo o economista, já é possível observar uma economia híbrida que evidencia o 'eclipse do capitalismo', ou seja, a mudança em curso de um paradigma do sistema capitalista para um novo sistema econômico colaborativo (RIFKIN, 2016).

Existe um crescente volume de publicações que convergem no sentido de pensar o advento das tecnologias digitais como a grande revolução na economia e no modo de fazer negócios. Para desenhar os contornos da revolução que prenuncia, Rifkin $(2012 ; 2016)$ produz uma estreita relação com às transformações sofridas pelas arquiteturas comunicativas nos contextos digitais e sua consequente produção de novas interações entre sujeito, tecnologias e espaços (in)formativos, para evidenciar o caráter colaborativo do social e do modo de vida contemporâneo. Com efeito, ao analisar a estreita relação entre sistema informativo e estrutura social, Joshua Meyrowitz nos aponta caminhos para entender a emergência do caráter colaborativo, interativo e compartilhado do social contemporâneo ao sublinhar que:

A situação social e os comportamentos no interior da sociedade podem ser modificados pela introdução de novos meios de comunicação [...]. A situação social pode ser considerada também como um sistema informativo, isto é, como um determinado modelo de acesso às informações sociais e como um determinado modelo de acesso ao comportamento das outras pessoas. (MEYROWITZ, 1985, p. 74 apud DI FELICE; TORRES; YANAZE, 2012, p. 138, tradução nossa).

Em um estudo mais contemporâneo, Massimo Di Felice (2008) produz um pensamento sobre o paradigma da comunicação em rede. Alinhado a um conceito de sistema informativo não dicotômico e de uma não distinção entre espaço físico e ambiente das mídias, o sociólogo analisa que, com o advento das tecnologias digitais, a comunicação passa a contemplar um novo 
paradigma em sua estrutura funcional, em que a comunicação se torna um processo de fluxo. Nelas, as velhas distinções entre emissor, meio e receptor se confundem e se trocam até estabelecer outras formas e outras dinâmicas de interação, que não permitem serem representadas segundo os modelos dos paradigmas comunicativos tradicionais. Trata-se de uma inédita alteração no sistema comunicativo, responsável pela criação de um complexo processo de comunicação entre as arquiteturas comunicativas, as informações, as coisas, as pessoas, os dispositivos e os territórios (DI FELICE, 2008), expressão de uma sociedade que se faz em fios das mais diversas formas de redes, onde a apropriação das novas tecnologias de comunicação e a não centralidade da informação produz trocas interativas, em que a co-ação desponta como dinâmica criadora do processo produtivo, comunicativo e social ${ }^{55}$.

Nesse sentido, ao considerar a estreita relação entre esta estrutura funcional comunicativa, os processos produtivos e a estrutura social, Ricardo Abramoway (2012) atribui à Internet a responsabilidade pela atual ampliação da escala de cooperação. Segundo ele, o que nós observamos hoje é um imenso potencial dos processos cooperativos no âmbito de economias descentralizadas, onde a criação de riquezas não está apoiada exclusivamente no ganho e na transação mercantil, mas também está ligada à finalidade daquilo que se produz. Neste contexto, a Internet e os processos cooperativos serão cada vez mais importantes na organização da vida econômica, completa o economista.

Ao buscarmos entender o contexto de transformações econômicas no qual as startups emergem, percebemo-lo não como um contexto de oposição ou de superação de um capitalismo velho e um novo capitalismo, mas sim como uma fase de transição para um novo tipo de capitalismo organizado em redes. Com efeito, Cocco (2013, p. 11) nos alerta para os riscos de tentarmos entender esta metamorfose como uma oposição entre dois tipos de capitalismo.

Uma das formas mais fracas e indigentes de apreender a mudança de paradigma é a de fazer oposição entre analógico e digital, como se houvesse um capitalismo analógico atrasado e um digital, mais avançado e mais "legal", "fofo". Na realidade, não há dois capitalismos, mas um só, e o modo de funcionamento do capitalismo contemporâneo se faz pelas redes e pelo digital, inclusive quando estamos em situações tradicionais. A contradição não opõe dois capitalismos, mas atravessa o novo capitalismo.

Nessa perspectiva, as startups digitais enquanto novos corpos no mercado, não prenunciam a superação do velho pelo novo ou expressam um desafio ou ameaça ao status quo,

55 Material audiovisual referente pesquisa Redes Digitais e Sustentabilidade, realizada pelo Centro de Pesquisa Atopos (ECA/USP), com patrocínio máster da Petrobrás e apoio institucional da ECA/USP. Disponível em: https://www.youtube.com/channel/UCVT7GXnGQBTcYNiXZFF9fvg. Acesso em 15 jun. 2016 
mas sim uma renovação, uma, digamos assim, inovação sobre o estabelecido ou ordenação do existente. Ao circunscrevermos o fenômeno das startups com a emergência de novas formas de produção hegemonizada pelo comando das máquinas e das relações em rede, podemos percebê-las como um fenômeno de um novo tempo, cujos processos caracterizam-se pela imprevisibilidade e novidade, o que faz surgir novas estruturas, comportamentos e propriedades com novas complexidades.

\subsection{PROTAGONISMO COGNITIVO}

Os estudos que buscam debater sobre o conjunto de transformações em curso na economia contemporânea, colocam em evidência as mudanças sofridas nas últimas décadas pelas relações de produção. A tese do trabalho imaterial (GORZ, 2005; LAZZARATO e NEGRI, 2001) é uma resposta teórica ao entendimento desse processo histórico de mudanças nas bases produtivas. O trabalho imaterial faz referência ao conjunto das atividades intelectuais, comunicativas e afetivas que conduzem à produção. Um trabalho cada vez mais intelectualizado em que a noção de imaterial nos remete a uma subjetividade produtiva (NEGRI, 2003).

O contexto de emergência das startups digitais provém de uma intensa produção de atividades que possuem como conteúdo central a comunicação, o conhecimento, o saber e a cooperação social na produção de um trabalho que é, sobretudo, intelectual. Expressão mesmo de uma época em que o saber da experiência, do discernimento, da capacidade de coordenar e de se auto-organizar é uma força produtiva central (GoRZ, 2005).

O protagonismo cognitivo é o ponto de partida para a noção de uma economia do conhecimento, que destaca em sua abordagem a dimensão imaterial da estrutura econômica contemporânea, onde o principal componente da agregação de valor, produtividade e crescimento econômico é o conhecimento como força produtiva do humano-máquina. Distante de considerar o conhecimento como um novo capital, o ineditismo aqui se detém ao fato de que o aproveitamento que se dava, em grande medida, através da mobilização de um saber objetivado em máquinas, instalações e processos, hoje tem o seu aproveitamento disposto em uma nova fronteira, ou melhor, em uma não-fronteira. Como assinala Gorz (2005), na economia do conhecimento, todo trabalho contém um componente de saber. Um tipo de saber que não é composto por conhecimentos específicos formalizados, mas sim um saber não formalizável, ou seja, um 'saber vivo', encontrado na base da inovação, da comunicação e da auto-organização criativa. 
O saber é, antes de tudo, uma capacidade prática, uma competência que não implica necessariamente conhecimentos formalizáveis, codificáveis. A maior parte dos saberes corporais escapa à possibilidade de uma formalização. Eles não são ensinados; aprendem-se-nos pela prática, pelo costume, ou seja, quando alguém exercita aquilo que se trata de aprender a fazer. Sua transmissão consiste em apelar à capacidade do sujeito se produzir a si próprio (GoRZ, 2005, p. 32).

Para o filósofo francês Pierre Lévy (1998), a prosperidade das nações, das regiões, das empresas e dos indivíduos depende cada vez mais de sua capacidade de navegar no espaço do saber. É na gestão ótima do conhecimento que a força é conferida, sejam esses conhecimentos técnicos, científicos, da ordem da comunicação, ou derivem na relação ética como os outros.

Quanto melhor os grupos humanos conseguem se constituir em coletivos inteligentes, em sujeitos cognitivos, abertos, capazes de iniciativas, de imaginação e de reação rápida, melhor asseguram seu sucesso no ambiente altamente competitivo que é o nosso. Nossa relação material com o mundo se mantem por meio de uma formidável infraestrutura epistêmica e de software: instituições de educação e formação, circuitos de comunicação, tecnologias intelectuais com apoio digital, atualização e difusão contínua dos savoir-faire ... Tudo repousa, a longo prazo, na flexibilidade e vitalidade de nossas redes de produção, comércio, e troca de saberes (LÉVY, 1998, p.19).

Negri (2003) reconhece uma forma de existência e de um mundo produtivo que se caracteriza pela hegemonia do trabalho intelectual. Uma época cognitiva em que a produção do valor depende cada vez mais de uma atividade intelectual criadora que emerge dos sujeitos e que se organiza na cooperação e do trabalho linguístico. Os teóricos do imaterial (LAZZARATO e NEGRI, 2001; GORZ, 2005) nos aponta para um tipo de capitalismo cognitivo, capaz de capturar os processos de subjetivação, tornando-os vetores de suas próprias revoluções. Esse capital cognitivo capta os elementos inovadores que produzem valor nas atividades sociais generalizadas. Ele se torna cognitivo não pelo fato de mobilizar o conhecimento, mas porque a situação na qual se produziam mercadorias por meio de conhecimento é alterada para um contexto em que o conhecimento passa a produzir, tautologicamente, o conhecimento. Nele, a base de manipulação da natureza passa a ser a produção e a manipulação de símbolos, onde:

A centralidade do trabalho imaterial diz respeito ao fato de suas atividades materiais (de transformação e manipulação da natureza) dependerem de seus elementos cognitivos, linguísticos e afetivos (de manipulação de símbolos). Ou seja, o trabalho material passa a depender do imaterial, onde o imaterial diz respeito à subjetividade: conhecimento, comunicação e afetos. (COCCO, 2013, p. 10).

Produzindo-se por meio da dimensão imaterial do trabalho hegenonizado pelo comando de máquinas e da manipulação inteligente e criativa de símbolos (LAZZARATO; NEGRI, 2001), as 
startups digitais apresentam modelos de negócios cada vez mais inteligentes, decenralizados e conectivos. Uma evidência objetiva são os softwares como serviço (SaaS). Considerados a nova geração de negócios digitais, os $S a a S$ são aplicações online que dispensam a instalação no computador e são usadas como um serviço pela internet. Os SaaS são, basicamente, sites que fazem uso da computação em nuvens - capacidade computacional de memória, armazenamento, cálculo e servidores compartilhados e interligados em rede, oferecendo serviços a partir de uma conexão com a internet. Algo possível anteriormente apenas por meio da aquisição de licenças para programas específicos e compra de computadores ou servidores para armazenamento de dados.

Hoje estes produtos dispensam sua dimensão material, passando a ser disponibilizados por links, acessos, logins e não por relações de licenças e aquisições (propriedade). Utilizados por usuários na própria web, sem a complexidade de instalações e aquisição de novas versões, os aplicativos web lideram o tipo de mercado explorado pelas startups brasileiras, que apresenta casos de sucesso, como a startup Conta $\mathrm{Azul}^{56}$, que oferece uma solução web para a gestão financeira de pequenas, grandes ou médias empresas, e a startup Resultados Digitais ${ }^{57}$, que trabalha, principalmente, com o desenvolvimento da plataforma $R D$ Station, reunindo diversas ferramentas de marketing digital ao alcance do usuário, por meio de relações de acesso.

Livres da complexa engenharia estrutural e funcional das organizações modernas que dominam os mercados tradicioais, as startups tem o conhecimento como seu principal vetor de produção. Elas encontram o fit com o mercado e ganham relevância através de propostas de valor mais eficientes, que mudam formas de consumo, hábitos e, sobretudo, mudam a maneira como as pessoas se relacionam com os produtos e serviços consagrados nos mercados tradicionais.

As startups digitais são encontradas em diferentes tipos de mercado, explorando territórios diversos. Elas podem ingressar em mercados existentes, apresentando novos produtos, clones ou reconfigurando estes mercados, por meio de uma segmentação que as permita colocar esforço naquilo que seus limitados recursos podem fazer a diferença. As startups também podem criar um mercado inteiramente novo, inventando uma nova classe de produtos que ninguém estava pensando antes, introduzindo um produto inédito, um produto substituto ou um variação de algo que existe (BLANK, 2014).

\footnotetext{
${ }^{56}$ Maiores informações sobre o serviço da startup Conta azul disponível em: https://contaazul.com/. Acesso em: 01 jun. 2016.

${ }^{57}$ Sítio da startup Resultados digitais disponível em: http://resultadosdigitais.com.br/. Acesso em: 01 mai. 2016.
} 
Quando esses novos corpos penetram nesses mercados tradicionais, percebemos, no contraste com o estabelecido, importantes elementos caracterizantes que singularizam o empreendedorismo startup, bem como o significado das relações que eles estabelecem com o status quo, como podemos acompanhar no case que segue.

\section{- Fin-techs: novos corpos no mercado financeiro}

Os bancos são exemplos clássicos de instituições tradicionais de negócios. Com estruturas robustas, procedimentos burocráticas e sob forte regulamentação, as instituições bancárias são os negócios legitimados à oferta de serviços financeiros. Entretanto, nos últimos anos, serviços como movimentação de dinheiro, emissão de cartões, concessão de empréstimos e contratação de seguros deixaram de ser serviços

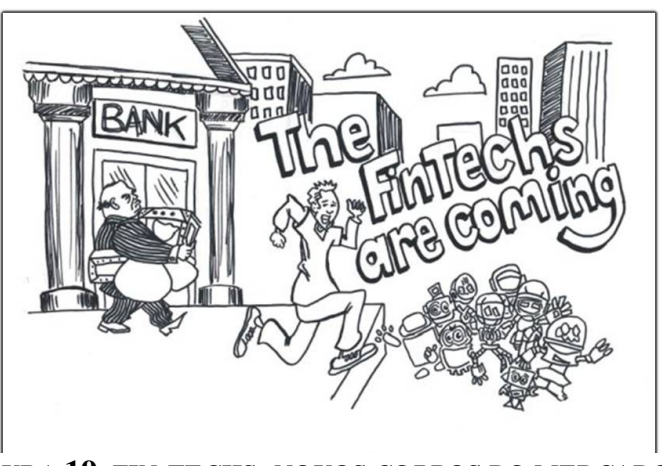
exclusivos dos bancos e seguradoras.

FIGURA 19. FIN-TECHS: NOVOS CORPOS DO MERCADO

No mercado financeiro, surgem, em escala crescente, as startups tecnológicas que conseguem entregar como produto ou serviço as funções básicas de um banco, através de soluções rápidas, baratas, convenientes, fáceis e personalizáveis, quando comparadas aos serviços financeiros tradicionais. São essas startups que recebem o nome de fin-techs, um acrônimo para as "tecnologias financeiras", e que representam todo um novo mercado que vem sendo contruído sobre a base do mercado financeiro tradicional, podendo assim ser definidas como empresas que prestam serviços financeiros, utilizando diferentes tipos de soluções hightech (ZAIATS, 2015).

As fin-techs constroem sua modelagem de soluções pontuais no setor financeiro em sinergia com a alta tecnologia de informação e comunicação, tais como: aplicações móveis, criptomoedas, cloud computing, plataformas online, arquiteturas peer-to-peer, analítica de dados, algoritimos preditivos e design. Oferecendo, a partir dessas tecnologias, soluções para resolver problemas comuns na relação das pessoas com os serviços bancários e promovendo mudanças nos modos e interação dessas pessoas com o mercado financeiro.

No lugar de recursos fixos como agências, grande número de funcionários e operações padronizadas complexas, há a participação intensa dos processos comunicativos e manipulação de dados que protagonizam as práticas das iniciativas fin-techs. Nestas startups financeiras, a produção de valor estrutura-se numa modelagem comunicacional, contruída por interfaces e 
plataformas, onde os intermediários são substituídos por alta tecnologia que conecta pontas produzindo inteligências e trocas informativas. Nesta direção, a criação do valor passa a depender muito menos das delimitações de produção em tempos e espaços, e mais das relações entre sujeitos e ações a-sujeitadas e de uma força conectiva, condições que as tecnologias digitais conferem ao empreendedorismo startup de aproximar as pontas, eliminando intermediários e se realizando pela produção de redes.
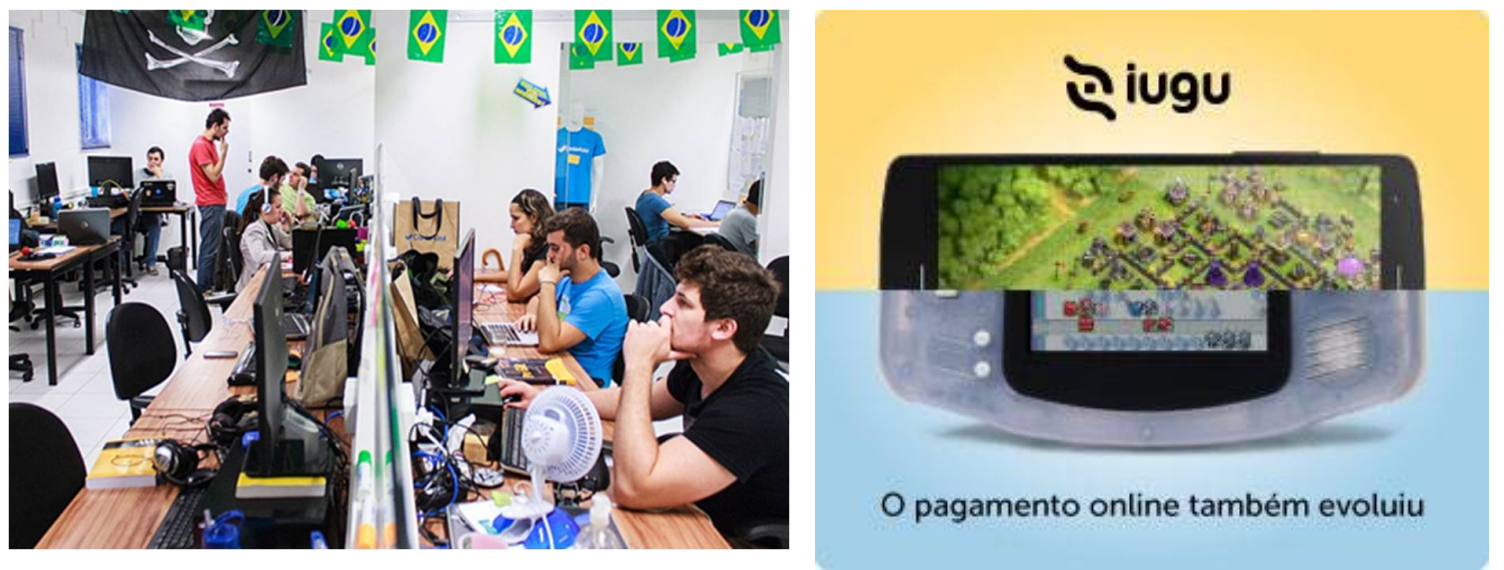

FIGURA 20. AS FIN-TECHS NO MERCADO B2 ${ }^{58}$

As startups de tecnologia financeira ganham relevância não só no mercado B2C como também no mercado B2B, permitindo aos autônomos e pequenos e médios empresários o acesso a serviços tecnológicos para ganhos de eficiência e produtividade. Nas imagens acima podemos acompanhar: (a) na figura à esquerda, a sede em Joinville (SC) da fin-tech brasileira ContaAzul, que oferece um conjunto de aplicativos online para gestão de micro e pequenas empresas, agregando inteligências aos processos de controle, gerenciamento e emissões de documentos, tudo baseado na computação em nuvem. (b) do lado direito, a iugu que é uma infraestrutura financeira em nuvem criada para oferecer eficiência nos pagamentos e cobranças da nova geração de negócios digitais.

A partir de infraestruturas inteligentes e comunicativas, essas iniciativas constroem uma cadeia digital de serviços financeiros desenhados no cliente e comunicando-se diretamente com ele, colocando as moedas digitais, empréstimos peer to peer, aplicações móveis, designers avançados e algoritmos sofisticados no dia a dia dos usuários de maneira simples e barata. Através da introdução destas tecnologias no mercado financeiro, as fin-techs encontram a relevância nas suas propostas de valor, mudando hábitos, mudando as formas de consumo e

${ }^{58}$ Fotos que ilustram reportagens disponíveis em: http://www.dci.com.br/inovacao-e-tecnologia/prodigios-criamempresa-de-pagamento-eletronico-id427651.html e http://projetodraft.com/um-mergulho-nos-bastidores-dacontaazul-a-premiada-startup-de-softwares-de-gestao/; http://www.dci.com.br/inovacao-e-tecnologia/prodigioscriam-empresa-de-pagamento-eletronico-id427651.html http://c.iugu.com/. Acessos em 13 abr. 2016. 
mudando o modo como as pessoas se relacionam com os serviços financeiros. Com estrutura organizacional enxuta, processos inteligentes e modelo mental orientado para experiência online, as fin-techs apresentam soluções que dialogam com o cliente mobile e digital, disposto a baixar uma série de aplicativos em seus smartphones ou navegar em plataformas como experiência de novas relações com os serviços financeiros.

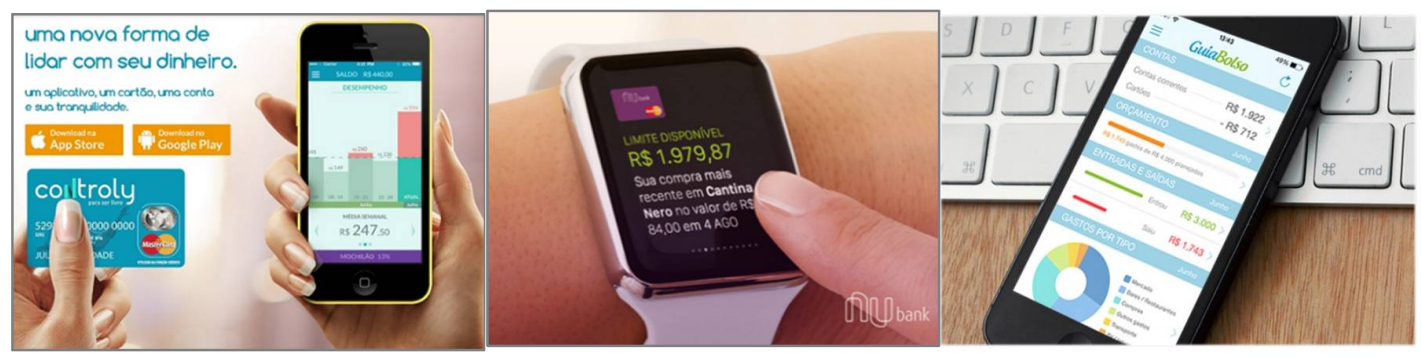

FIGURA 21. AS FIN-TECHS NO MERCADO B2C ${ }^{59}$

O mercado B2C reúne também um grande número de fin-techs, que apostam na experiência mobile e 100\% digital. Na ilustração temos: (a) na primeira imagem à esquerda, a comunicação da startup Controly. Voltada para a geração millenius, a startup oferece uma alternativa à conta-corrente tradicional, sendo exclusiva para usuários de dispositivos móveis, atrelada a um cartão de crédito pré-pago internacional gratuito e aplicativo móvel para gestão dos gastos e gestão financeira; (b) na segunda ilustração, o App Nubank, cartão de crédito totalmente online para usuários de smartphone com sistema iOS ou Android, apple Watch, tablets ou relógios inteligentes que usam o sistema Android. (c) na imagem à direita, a startup GuiaBolso, com mais de 1 (um) milhão de usuários ativos, ele sincroniza as contas bancárias dos usuários permitindo o controle de gastos e gestão financeira de forma instantânea.

É exatamente essa condição high-tech que lhes confere infraestrutura e know-how para alcançarem baixos custos dos seus serviços e grande eficiência em suas soluções. A redução de capital fixo permite às startups de tecnologia financeira um alavancagem operacional e velocidade de inovação que lhes conferem vantagem quando comparadas às modelagens tradicionais institucionalizadas de serviços financeiros. Estas iniciativas impactam o setor financeiro através da (re)modelagem pontual de serviços e produtos financeiros, infestando o mercado tradicional com soluções inovadoras que surrupiam seu portfólio de serviços. Oferecer tais facilidades representa um grande desafio aos modelos tradicionais institucionalizados,

\footnotetext{
${ }^{59}$ Fotos que ilustram reportagens disponíveis em: http://www.dci.com.br/inovacao-e-tecnologia/prodigios-criamempresa-de-pagamento-eletronico-id427651.html e http://projetodraft.com/um-mergulho-nos-bastidores-dacontaazul-a-premiada-startup-de-softwares-de-gestao/ ; http://www.dci.com.br/inovacao-e-tecnologia/prodigioscriam-empresa-de-pagamento-eletronico-id427651.html http://c.iugu.com/ Acesso em 13 abr. 2016.
} 
provocando-os a (re)pensar suas dinâmicas e modi operandi, que se mostram impotentes para responder à velocidade de inovação dessas iniciativas.

Em resposta, os bancos convencionais realizam esforços não só na oferta de produtos digitais e mobile, mas também em ações de cooperação e complementariedade com o ecossistema startup, buscando uma aproximação e um relacionamento com estas startups como modo de participar e/ou antecipar a inovação nos seus mercados. O Banco Itaú em parceria com a Redpoint Eventures inaugurou recentemente o espaço Cubo, Coworking para startups, visando estar próximo dessas iniciativas de inovação tecnológica. Temos também a iniciativa do Banco Bradesco, que já realiza a sua segunda edição do InovaBRA, programa de inovação aberta voltado para a adoção de alta tecnologia para soluções financeiras ${ }^{60}$.

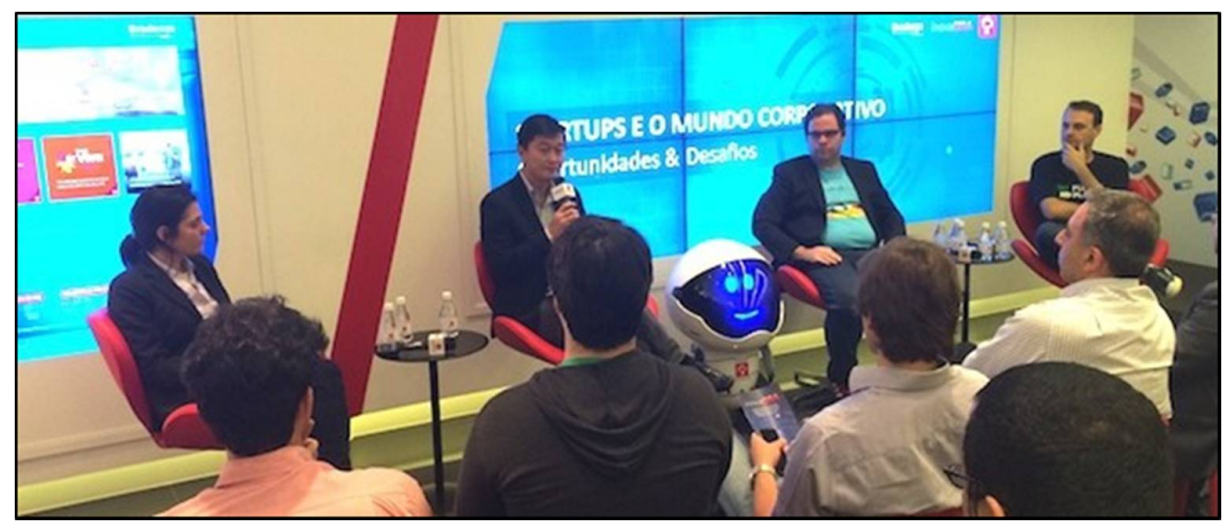

Figura 22. AS STARTUPS E AS GRANDES EMRESAS ${ }^{61}$

Painel no Espaço Bradesco Next realizado pelo programa InovaBra discute sobre como as corporações se relacionam com as startups. No painel, da esquerda para a direita, Silvia Valadares (Gerente da Microsorft BizSpark e Microsoft Innovation Center), José Papo (Gerente de relação com startups e desenvolvedores da Google); Rogério Tamassia (na época representante da aceleradora Abril Plug and Play) falam sobre suas atuações de assistências complementares ao ecossistema startup, tendo como contrapartida buscar parcerias, a compreensão de outras maneiras de fazer negócio e a busca de ideias inovadoras.

$\mathrm{Na}$ vida imaterial o saber é força produtiva central e assim o trabalho permeia a dimensão da vida cotidiana, misturando o tempo de vida e tempo de trabalho como potencialidades produtivas. Conforme reflete Cocco (2013, p 13): "Na medida em que o trabalho se torna imaterial e o capital mobiliza a subjetividade, é a própria vida como um todo que é posta para trabalhar". Assim, se nas estruturas industriais era necessário abrir mão da

60 Espaço Cubo Coworking disponível em: https://cubo.network/ e InovaBra em: http://www.inovabra.com.br/html/index.shtm. Acessos em: 01 abr. 2016

${ }^{61}$ Ciclo de Palestras - Startups e o Mundo Corporativo: Oportunidades e Desafios. Realizado em 2014 Ver em: https://youtu.be/HDeyOtvwqZc. Acesso em: 22 abr. 2016. 
subjetividade para entrar em um agenciamento salarial entre muros, hoje o trabalho é mobilizado diretamente nos territórios das redes.

Os serviços e os territórios que suas redes desenham tornam-se os espaços desse novo tipo de produção, cuja produtividade não depende mais (apenas) da eficiência do agenciamento fabril (ou seja, da composição orgânica do capital fixo e variável e sua relação salarial), mas da geração (no sentido mesmo da geração da vida) de outro tipo de capital, aquilo que é chamado de capital humano, intelectual e social (COCCO, 2013, p.13).

Para Gorz (2005), o trabalho imaterial repousa essencialmente sobre as capacidades expressivas e cooperativas que não se podem ensinar, sobre uma vivacidade presente na utilização dos saberes e que faz parte da cultura do cotidiano. Consiste em um trabalho que se realiza em uma razão cooperativa e comunicativa, expressão de uma socialização dos saberes, das subjetividades dos trabalhadores, dos dispositivos tecnológicos e organizativos (LAZZARATO; NEGRI 2013). Isso ocorre bem diferentemente dos trabalhadores de manufaturas e ou de indústrias taylorizadas que só se tornam operacionais após serem despojados dos saberes, das habilidades e dos hábitos desenvolvidos pela cultura do cotidiano e submetidos a uma divisão parcelada do trabalho. Em contrapartida, ao trabalhadores do mundo imaterial, entram no processo de produção com toda a bagagem cultural que eles adquiriram não só no trabalho, mas também no seu tempo de não trabalho. Para ele são nessas atividades fora do trabalho que são desenvolvidas sua vivacidade, sua capacidade de improvisação e de cooperação (ibidem). Mais que um possuidor de sua força de trabalho hetero-produzida, o trabalhador do imaterial é um produto que continua, ele mesmo, a produzir se.

Assim, o trabalho do 'saber vivo' na economia em rede é, sobretudo, o trabalho do sujeito cuja atividade é produzir a si mesmo (GORZ, 2005). Nesta acepção, a distinção entre a empesa e o sujeito e entre a força de trabalho e o trabalho é suprimida. Carregando consigo o seu próprio capital, a pessoa deve ser sua própria produtora. Eis a emergência dos autoempreendedores, aqui os novos idealistas, que se projetam em um contínuo:

- Produzir-se: o modo de incorporação do 'saber vivo' exige um investimento em si mesmo - "A pessoa deve para si mesma tornar-se uma empresa; ela deve se tornar como força de trabalho, um capital fixo que exige ser continuamente reproduzido, modernizado, alargado, valorizado." (GORZ, 2005, p. 23). 
- Mobilização Total: as atividades do trabalho, e também fora dele, mobilizam as mesmas competências, promovendo, assim, um acionamento geral de capacidades e disposições - "A atividade de produção do si é uma dimensão necessária de todo trabalho imaterial, e este tende a apelar às mesmas capacidades e às mesmas disposições pessoais que possuem as atividades livres, fora do trabalho" (Gorz 2005, p. 22).

- A vida é business: o autoempreendedorismo generalizado e a subsunção de toda a pessoa e da vida, pelo capital.

A partir de então, todo mundo faz comércio [...]. Todo o mundo estará constantemente ocupado fazendo business com tudo: sexualidade, casamento, procriação, saúde, beleza, identidade, conhecimentos, relações, ideias etc. [...] Nós estaremos constantemente ocupados em fazer todos os tipos de negócios [...] Mesmo os assalariados serão empreendedores individuais, gerindo suas carreiras como a de uma pequena empresas [...], prontos a se conformarem às exigências e novidades. A pessoa se torna um empreendimento. (LÉVY, 2000, p.8486 apud Gorz, 2005, p. 25).

O trabalhador em rede está em sincronia contínua com os outros e com os dados que manipula, colocando em marcha um processo em que o resultado coletivo excede a soma dos dados manipulados individualmente (GoRZ, 2005). No trabalho interativo em rede, é virtualmente abolida a divisão do trabalho em tarefas especializadas e hierarquizadas, bem como a separação entre os trabalhadores e seus trabalhos. Neste contexto, os meios de trabalho se tonaram apropriáveis e suscetíveis de serem partilhados. O trabalho imaterial não exige comando.

A difusão do saber em forma reticular se oferece, então, potencialmente como uma excelência em relação ao conjunto de obstáculos que se lhe apresentam. (...) O trabalho, hoje, para ser criativo deve ser "comum", ou seja, produzido por redes de cooperação. (NEGRI, 2003, p. 153)

\subsection{MÁQUINA PRODUTIVA}

A cooperação opera como um dispositivo principal das produções das startups - ou seja, uma conjunção geral das potências produtivas de uma multiplicidade de sujeitos em ação. Do ponto do vista das startups, chamamos esses sujeitos de Novos Idealistas. Naturalmente não estão sós. São habitantes dos ecossistemas-redes, do mundo maquínico, da vida-link. A cooperação não é uma imposição, mas um 'modo-de' que Negri (2003) intitula de “força implícita" na própria arquitetura social. Poderia até afirmar uma força implícita em rede, mas 
de fato já não existe um "fora", um off-line. Portanto, o que faz com que Negri afirme que não há produção sem cooperação, esta última é, pois, de fato, a categoria central da análise da sociedade contemporânea.

Negri (2003) analisa que a produção social se apresenta como uma multiplicidade de atividades sempre mais cooperativas dentro do processo de produção. Nela o indivíduo social e coletivo representam cada vez mais os elementos centrais qualificadores da produção e seu valor. A cooperação produz um indivíduo coletivo por meio do qual esse autor faz projeções sobre os novos modos de viver e produzir:

Será um indivíduo social e coletivo que determinará o valor da produção, pois, sendo o trabalho organizado em formas comunicativas e linguísticas, e o saber sendo algo cooperativo, a produção dependerá sempre mais da unidade de conexões e de relações que constituem o trabalho intelectual e linguístico, isto é, dependerá, então, desse indivíduo coletivo. (NEGRI, 2003, p. 93)

A mudança do modo de produção por meio da hegemonia da força-trabalho imaterial e do trabalho vivo cooperativo, incorpora ao trabalho aquilo que é mais comum ao homem: a sua comunidade, a sua capacidade de se vincular, de se comunicar (NEGRI, 2003). Quando a cooperação vem para um nível central da produção, então a comunicação torna-se digamos assim "o combustível” da produção. Assim, a nova organização do trabalho e o próprio novo modo de produção tem como base aquilo que há de mais comum na vida dos homens: a linguagem (NEGRI, 2003). Com efeito, o design é hoje apontado como a linguagem dos novos negócios digitais. As startups de tecnologia como Airbnb, Spotify, Dropbox têm cada vez mais usado princípios guiados pelo design de produto para solucionar problemas e oferecer novas experiências aos seus usuários ${ }^{62}$.

Dentro desse contexto de intensas transformações na economia contemporânea, o trabalho como dispositivo cooperativo ganha destaque, nas últimas décadas, nas literaturas empresariais que apontam como as relações e trocas sociais ganharam uma importância inédita como um fenômeno econômico. Nessas abordagens, o olhar está em como as tecnologias digitais e a Internet criam uma esfera do comum (CASTELLS, 1999) e provocam a ampliação das formas cooperativas de produção que derivam de uma cooperação intrínseca ao trabalho imaterial em rede. Distante de ser algo novo, as produções cooperativas ganham escala com a ampliação dos processos comunicativos de colaboração, intensificadas pelo advento das novas

\footnotetext{
62 Do documentário "Design Disruptors" que investiga como o design se tornou a nova linguagem nos negócios. Disponível em: http://www.b9.com.br/61040/design/design-disruptors-documentario/. Acesso em 17 jun. 2016.
} 
tecnologias digitais. O que permite a saída da competência de produção e da capacidade de inovação para fora das estruturas organizacionais tradicionais (RIFKIN, 2016).

Desse contexto emergem arranjos econômicos que se realizam pela articulação livre de pessoas imersas em um ecossistema comunicativo, marcado pela presença de infraestruturas descentralizadas de compartilhamento, de espaços inteligentes, de dispositivos tecnológicos portadores de extraordinário potencial produtivo e de uma tecnologia aberta a novas aplicações. Ampliando, dessa forma, as oportunidades e as capacidades das pessoas de exercerem condição de agentes econômicos ou criar novas formas de participação na economia.

Ao analisar as novas formas de participação na economia e a relação que estas estabelecem com as estruturas tecnológicas comunicativas, o pesquisador de redes e codiretor docente do Centro Berkman para a Internet e Sociedade da Harvard University, Yochai Benkler, nos alerta para a diferença nos efeitos provocados pela introdução de novas tecnologias em séculos passados e o advento das novas tecnologias digitais nas últimas décadas. Se aquelas tinham como tendência fomentar a concentração de comercialização, produção e distribuição, bem como controlar o alcance geográfico e social de seus efeitos e dimensões, criando uma dicotomia entre um polo ativo responsável pela geração de riqueza e um polo passivo receptor das condições de agência deste primeiro polo, estas últimas, as tecnologias digitais, tendem a alterar o vetor de controle e habilitação de usuários, permitindo adaptações econômicas, sociais e culturais (BENKLER, 2006), produzindo agências que permeiam todo o tecido econômico de maneira fluida, conexa e heterogênea.

Um dos vetores fundamentais que impulsionam e desenham os contornos dessas transformações nas atividades econômicas é o tecimento de uma nova relação social produtiva. Em paralelo ao modelo tradicional de produção, desenvolve-se um novo modelo produtivo fortemente caracterizado por ação descentralizada individual, práticas colaborativas de grande alcance social, liberdade individual de participação, livre iniciativa e motivações diversas. O fenômeno da produção por meio da ação do indivíduo não como um ator de mercado e subordinado a um sistema mercadológico, mas com uso da sua singularidade e plena utilização de suas novas expansões práticas de liberdades são analisados também (BENKLER, 2002).

Durante décadas, a nossa compreensão de como os indivíduos organizam suas atividades produtivas tem sido realizada em uma de duas formas: quer como empregados em empresas, seguindo as instruções dos gerentes, ou, como indivíduos nos mercados, acompanhando os sinais dos preços. (...) Nos últimos três ou quatro anos, a atenção do público tem se concentrado em um recente fenômeno econômico-social de desenvolvimento mundial de software que ocorre há quinze anos. (...) Sugiro que estamos assistindo a emergência de um novo, amplo e 
profundo terceiro modo de produção no ambiente das redes digitais. Eu chamo este novo modo de "produção coletiva e comum entre pares", para distingui-la dos modelos de empresas e mercados baseados em contratos e em propriedade. Sua característica central é que grupos de indivíduos colaboram com sucesso em projetos de grande escala seguindo um conjunto de diversas motivações e sinais sociais, ao invés dos preços do mercado ou dos comandos gerenciais. (BENKLER, 2002, p.3)

Esses fluxos vitais do processo de colaboração, evidenciados inicialmente em iniciativas grandiosas como o clássico projeto de enciclopédia de licença livre, a Wikipédia, ${ }^{63}$ e o movimento de softwares livres, estão transcendendo as relações de produção e caminhando para a construção de um ecossistema que amplia os efeitos dos agentes individuais livres e do potencial transformador dessas estruturas tecnosociais e produtivas. Estas estruturas oferecem condições para invenções de novos circuitos de criação e produção dentro da economia.

A cultura e as infraestruturas "co" e "crow" 64 , ao quebrar barreiras tradicionais de investimento, capital intelectual, capital físico, têm criado oportunidades para as pessoas se articularem economicamente em ideias, projetos, iniciativas, fazendo emergir ações empreendedoras cujas configurações e dinâmicas apresentam uma qualidade diversa das organizações econômicas tradicionais. Ao produzirem bens e serviços até então oferecidos de maneira eficiente unicamente por estruturas centralizadas, essas iniciativas emergentes descentralizadas provocam alterações no modo como a sociedade se organiza na oferta desses bens e serviços.

Assim, a estrutura econômica até então controlada e reservada aos detentores dos fatores de produção ganha porosidades, fazendo emergir novos vetores de ação. Conforme refletem Willian \& Tapscott (2007), se antes as pessoas estavam confinadas a papéis econômicos relativamente limitados e excluídas da circulação de conhecimento, poder, capital e, portanto, participavam à margem da economia, hoje o acesso crescente à tecnologia da informação, a comunicação e o conhecimento têm ampliado as condições necessárias para as pessoas cooperarem, competirem e criarem riqueza em cada setor da economia.

Percebemos, nas iniciativas de inovação que emergem dessa condição, que a produção de valor passa cada vez mais pela captação de elementos produtivos e de riqueza social que estão fora do processo produtivo direto tomado em si. Sua produtividade é reconhecida como algo que surge do grau de inovação e da intensidade da cooperação. Assim, por meio da absorção dessa cooperação e da institucionalidade sociais na vida econômica é que se produz

\footnotetext{
${ }^{63}$ Disponível em: https://www.wikipedia.org/. Acesso em 20 jun. 2016

${ }^{64}$ Refiro-me aqui às plataformas e espaços como crowdfunding, crowdsourcing, co-learning, coworking, cocriation, etc.
} 
rendimentos crescentes. Com efeito, o conjunto da cooperação social é uma matéria-prima que não se gasta, mas que se acrescenta ainda na produção, como Negri (2003) nos projeta.

Os processos cooperativos são percebidos com grande intensidade nos tecimentos das ações de criação das startups através de redes de compartilhamento e criação de processos sociais criativos, podendo estas relações sociais de produção, potencializadas pelas tecnologias digitais, serem incorporadas de maneira particular no próprio modelo de negócio da startup, criando modelagens cuja dinâmica se realiza pela construção de relações horizontais de produção colaborativas entre produtores e usuários. Nestas modelagens, essas iniciativas produzem a desintermediação, conectando serviços a usuários de madeira direta e excluindo players tradicionais na cadeia produtiva. São nestes casos, principalmente, que as startups enfrentam controvérsia em torno da legalidade e operam diante de riscos regulatórios, como percebido em um dos cases mais emblemáticos de startups digitais.

\section{- Rede de pessoas e ativos para soluções de mobilidade}

A prática de compartilhamento de carros e aplicação de mobilidade vêm ganhando espaços e se popularizando principalmente nas grandes capitais do mundo. No Brasil o modelo pode ser visto nas startups como pegcar, zazcar, Fleety ${ }^{65}$, que, embora apresentem pequenas variações em seus modelos

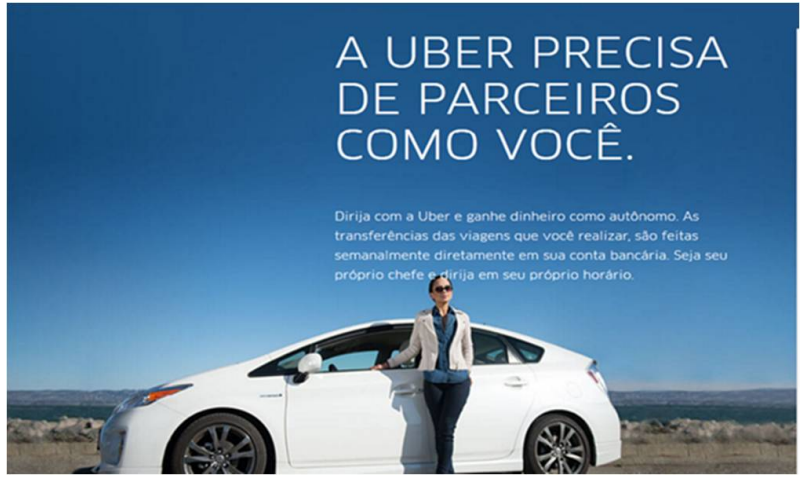

FIGURA 23. UBER E MOTORISTAS PARCEIROS de negócios, na prática são iniciativas que vêm construindo uma rede de automóveis que podem ser acessados através de interfaces e plataformas. Imersas em um ecossistema comunicativo que oferece condições para que os bens, as pessoas e os espaços se conectem em redes compartilhadas, essas iniciativas startup de mobilidade produzem arquiteturas comerciais inéditas e criam novas modelagens de negócios capazes de impactar um grande número de pessoas através do alcance de uma economia de escala.

É dentro desse ecossistema comunicativo que emerge o Uber. Nascido da ideia de criar uma plataforma tecnológica capaz de conectar o motorista ao passageiro e tornar mais fácil a tarefa de pegar uma carona e conseguir um cliente, o aplicativo inaugura o conceito $e$-hailing,

65 Sites das startups citadas, respectivamente: https://pegcar.com/ e https://www.zazcar.com.br/ e https://www.fleety.com.br/. Acessos em 06 jun. 2016 
modelagem que vem sendo usada como referência para a criação de novos modelos de negócios baseados na relação de acesso, na descentralização da rede, no compartilhamento de ativos e inteligências para criação de novas maneiras de interação em grande escala. Apertar um botão e pegar uma carona - um insight inicial, que mais parecia uma daquelas ideias em brainstorming, ganha corpo e configura-se num modelo de negócio altamente lucrativo e promissor no mercado de mobilidade urbana. É comum ouvir no mercado de negócios digitais e das novas startups o termo 'urberização', fazendo referência ao modelo Uber de negócio.

Presente em mais de 67 países, o Uber é a empresa tecnológica americana de maior reconhecimento em serviços de transporte individual de passageiros com motoristas particulares, tornando-se o case mais apontado da economia de aplicativo mobile no mundo. No Brasil, o Uber é considerado uma startup, apresentando um crescimento orgânico viral de mais de meio milhão de usuários, em 2015, no País, e mais de cinco mil motoristas parceiros ${ }^{66}$. Os seus sete anos de operação não foram suficientes para confirmar o seu modelo de negócio. Embora apresente escala crescente, a startup encontra gargalos para operar em algumas cidades em que atua, convivendo com riscos regulatórios.

Mesmo em uma contracorrente, o Uber vem ampliando sua geografia de atuação e o seu portfólio de serviços. Com o propósito de ser não só um aplicativo que conecta o motorista ao passageiro, mas um promotor de mudanças na maneira como as pessoas e as coisas se deslocam nas cidades, o Uber não só oferece soluções de mobilidade, como também apoia projetos de pesquisas junto ao Google no desenvolvimentos de carros inteligentes e serviços de mobilidade para o futuro.

Na prática, o Uber usa o GPS do telefone do usuário para descobrir sua localização e conectá-lo ao motorista disponível mais próximo. Quando o usuário solicita uma viagem, o aplicativo encontra um motorista e permite que o usuário rastreie sua localização no mapa. Quando seu motorista chega é enviado ao usuário uma mensagem com o nome do motorista e informações do carro serão exibidas no aplicativo do celular. Ao chegar no destino, a tarifa é debitada automaticamente do cartão de crédito informado e o usuário pode avaliar sua experiência e deixar um comentário sobre o seu motorista.

Por trás da ideia, a participação de tecnologias digitais emergentes que vêm de maneira veloz alterando as relações das pessoas com o espaço, o tempo e a comunicação. Com o uso de informações georreferenciadas produzidas pelos espaços wireless, com a exploração de novos processos comunicativos descentralizados, o aplicativo Uber explora a sensibilidade e

66 Informações disponíveis em: https://newsroom.uber.com/brazil/serao-30-mil-oportunidades-de-trabalhocriadas-no-brasil-ate-outubro-de-2016-e-o-compromisso-da-uber/. Acesso em 01. Abr. 2016. 
interatividade dos dispositivos móveis para produzir uma arquitetura comercial pela qual suas operações se realizam. Substituindo métodos tradicionais como ligações telefônicas ou simplesmente esperar ou ir à busca de um veículo na rua, o UBER vem operando em alinhamento com a natureza compartilhada e distributiva das novas tecnologias e ampliando suas dimensões de serviços através da exploração comercial do potencial espacial conectado e da comunicação descentralizada, produzindo-se em um ecossistema comunicativo.

Estreitamente alinhado às transformações sofridas nos modos como a sociedade consome, produz e distribui informações nos espaços urbanos, o Uber tem suas operações centrais produzidas em um espaço relacional, onde suas atividades se realizam por meio de dispositivos móveis sensíveis ao ambiente e interativos em relação ao contexto em que estão inseridos e através de ações complexas de diversos atores capazes de alinhar mobilidade e a geolocalização.

Considerada uma empresa de tecnologia, o Uber não possui um motorista no corpo social da empresa e nem um carro no seu ativo fixo. Assim os motoristas parceiros, como a startup se refere, ao atenderem alguns requisitos, entram na rede e compartilham os seus veículos, oferecendo o serviço de transporte individual de passageiros. A monetização ${ }^{67}$ ocorre da seguinte forma: um percentual do valor das viagens é transferido aos parceiros semanalmente e o percentual restante fica com a Uber pelo uso da plataforma tecnológica.

Tendo como propósito ocupar as principais cidades do mundo e criar uma oferta alternativa de transporte individual de passageiros com base no compartilhamento do ativo automóvel, o Uber leva, através do acesso, à experiência de um transporte de eficiência e conveniência. Para isso trabalha com flexibilidade para oferecer alternativas de serviços que se adaptem às realidades locais em que se insere.

Para isso, o Uber apresenta como requisito possuir carros específicos para elegibilidade em suas categorias ${ }^{68}$ de serviços. Os motoristas trabalham com critério de reputação, resultado

\footnotetext{
${ }^{67}$ As categorias de serviços e modelos de serviço sofrem diferenciações para se adaptar ao perfil dos mercados nas distintas cidades e países. Na cidade de São Paulo os serviços atendem duas categorias a saber: a UberX e a UberBLACK. Na UberX, $75 \%$ do valor das viagens é transferido aos parceiros semanalmente. Os $25 \%$ restantes ficam com a Uber pelo uso da plataforma tecnológica. Nesta categoria a tarifa base é de $\mathrm{R} \$ 2,0+\mathrm{R} \$ 0,26$ por minuto + R\$ 1,40 por Km. A tarifa mínima é de $\mathrm{R} \$ 7,00$ e a taxa de cancelamento também é de $\mathrm{R} \$ 7,00)$. Já na categoria UberBLACK, $80 \%$ do valor das viagens é transferido aos parceiros semanalmente. Os $20 \%$ restantes ficam com a Uber pelo uso da plataforma tecnológica. A tarifa básica de $\mathrm{R} \$ 3,80+\mathrm{R} \$ 0,28$ por minutos $+\mathrm{R} \$ 2,32$ por Km. A tarifa mínima $\mathrm{R} \$ 9,00$ e taxa de cancelamento também de $\mathrm{R} \$ 9,00$. Disponível em: https://www.uber.com/?exp=hp-c. Acesso em 01. Set. 2015

${ }^{68}$ Em São Paulo, o motorista pode se cadastrar em uma das categorias oferecidas (Categoria UberX: como requerimento geral os carros devem possuir: 4 portas, ar condicionado, qualquer cor menos branca e amarela; Categoria UberBLACK (Requerimentos: 4 portas, ar condicionado e bancos de couro. Em cada categoria o Uber apresenta uma lista de carros elegíveis para cada categoria e cada categoria tem requerimentos a serem atendidos.
} 
de avaliação feita por usuários em seu smartphone ao final de cada corrida. As tarifas que são calculadas por tempo (minutos) e por distância $(\mathrm{km})$ ao mesmo tempo não são pagas através de dinheiro em espécie ou máquinas de cartão de crédito, uma vez que a transação e o envio do recibo via e-mail é feito pelo próprio aplicativo com os dados disponibilizados pelo usuário no momento em que fez o download do aplicativo.

Para os motoristas particulares e seus usuários, nenhuma taxa de processamento é cobrada. O Uber opera na geração de valor para as duas pontas: para os motoristas oferece uma plataforma que permite que estes conectem seus veículos à rede como alternativas de renda extra e uma atividade remunerada flexível. Já para o usuário oferta-se o acesso a um eficiente deslocamento nas grandes cidades, somada à ausência de gastos e custos fixos intrínsecos à posse do veículo.

É no centro do modelo de negócio Uber que reside a controvérsia. Ao trabalhar com motoristas autônomos que conectam na rede os seus automóveis particulares para produção de valor sem intermediários, o Uber se reconhece dentro da incipiente economia de compartilhamento. Por oferecer um serviço muito semelhante ao serviço tradicional de taxi, os taxistas e suas cooperativas acusam o aplicativo de praticar uma concorrência desigual por não arcar com custos de regulamentação como alvarás e licenças, além de praticar a atuação ilegal da profissão ao violar a legislação nacional (a Lei 12.468/2011, que confere aos taxistas o direito de explorar o serviço de transporte individual remunerado de passageiros).

Posicionando-se como uma empresa de tecnologia e não de taxi, o Uber rejeita a dicotomia entre os dois serviços, comunicando-se como uma alternativa que contribui para a solução dos problemas de mobilidade urbana. Para isso, o Uber elimina intermediários e constrói pontos de conexão entre pessoas e carros para criar diversas alternativas de serviços que operam em rede, aumentando a eficiência de bens que ficariam parados, e gerando oportunidades de renda. Edu Tellis, General Manager da Uber Brasil, aponta a urgente necessidade de aprimorar a legislação e a compatibilização de novos serviços e tecnologias. Para ele, o conflito regulatório não existe, e sim inexiste regulamentação correspondente aos novos negócios digitais.

O Uber também lista veículos não aceitos em nenhuma das categorias. Disponível em: https://www.uber.com/?exp=hp-c. Acesso em 01 set. 2015. 
Diante na inovação o serviço público tem que entender que isso pode melhorar a vida da população e trazer benefícios para a sociedade. O papel do Uber e do regulador é suportar o progresso, não punir o progresso. Então, o que a gente trabalha é em mostrar o que Uber pode fazer pela cidade como melhorar a mobilidade e gerar oportunidade de renda. É esse o papel do Uber. É isso que queremos fazer. O papel do regulador é dar esta estrutura. O plano de mobilidade nacional fala que tem dois tipos de transporte: público e privado. O Uber se encaixa como modalidade de transporte privado o que falta é a regulamentação ${ }^{69}$.
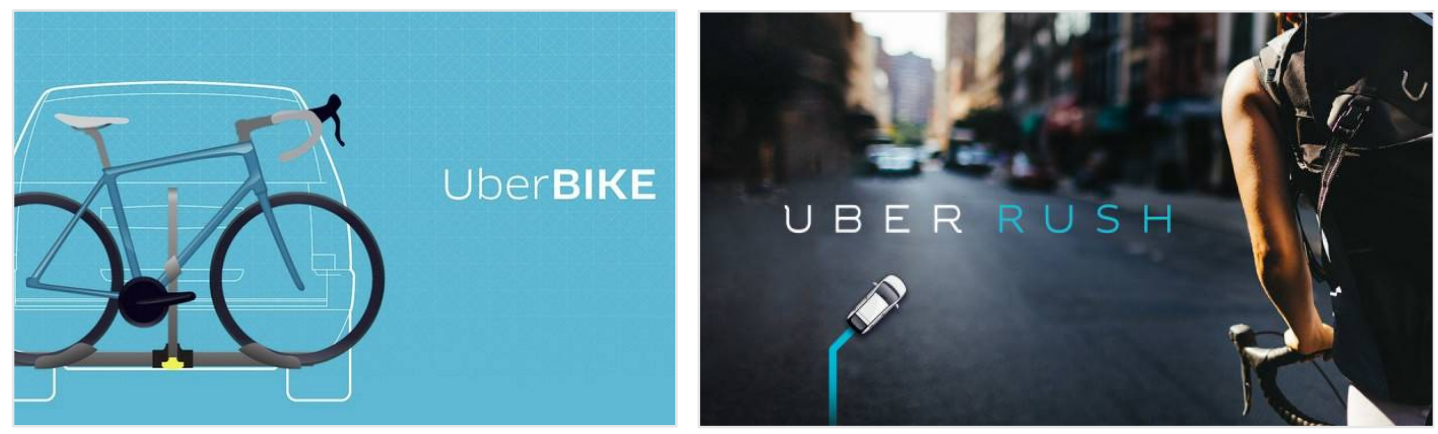

FIGURA 24. O CONCEITO UBER

Aplicativo explora comercialmente novas experiências de inserção no espaço urbano com oferta de serviços que variam de acordo com as cidades em operação $^{70}$

A controvérsia Uber aponta para uma realidade dos negócios de internet que não é uma particularidade dos modelos de negócios compartilhados e muito menos exclusividade do Uber, mas sim das novas modelagens digitais de negócios, que esbarram em regulações que não conseguem dar conta da complexidade dessas iniciativas de inovação. Trata-se de negócios que se realizam por meio de operações em rede e da participação crescente de tecnologias digitais, softwares, bancos de dados, dispositivos, inteligência artificial, algoritmos. Em seus diferentes segmentos, o afastamento entre inovação e regulação podem ser sentidos como: emissões de cartão de crédito $100 \%$ digital, sem a presença de uma instituição bancária, (Nubank); aplicativo de mensagem gratuito instantâneo, sem a participação de empresas de telecomunicação (Whatsapp); plataforma compartilhada para aluguél de quartos ociosos fora da indústria hoteleira (AirBNB); aplicativos de chamadas de taxi sem intemediação de cooperativas (Easy Taxi e 99taxi); disponibilidade de uma quantidade quase infinita de músicas

69 Entrevista concedida por Gui Telles, General Manager Uber Brasil para o videocast sobre empreendedorismo e cultura digital. Entrevistadores: Leo Cuba e Miguel Cavalcante. Disponível em: https://youtu.be/2Cjx93XWgm0. Acesso em 02 abr. 2016.

70 Imagem disponíveis respectivamente em: https://tecnoblog.net/181754/uberbike-sao-paulo-brasilia/ e https://rush.uber.com/how-it-works 
em tempo real, livre de estratégias de distribuição do mercado da música (Spotify); mobile que conecta motoristas e ativo em rede para oferecer carona a quem precisa sem taxistas (Uber); documentos disponíveis na nuvem (Dropbox).

\subsection{CONHECIMENTO EM ESCALA}

O desejo-motor das startups é a produção em alta escala. Ao fazer o "engenho" da escalabilidade, as startups se projetam. Com efeito, as teorias da sociedade imaterial apresentam essa condição como uma qualidade dos desenvolvimentos das técnicas e extensão dos cérebros humanos para cérebros-máquinas. Pautadas no crescimento exponencial, as startups digitais atravessam a zona cinzenta com o desafio de encontrar um modelo de negócios de qualidade replicável. Para isso, ancoram-se no advento das tecnologias digitais que lhes assegurem a multiplicação de reprodução em série, conferindo-lhes modelos de negócios com extraordinária potencial de reprodutibilidade e alcance de grandes escalas de crescimento. As startups precisam encontrar na essência de suas criações o potencial reprodutível.

A existência serial perseguida pelas startups se aproxima dos conceitos de "aura" e "reprodutibilidade técnica" desenvolvidos por Walter Benjamin na publicação 'A obra de arte na era de sua reprodutibilidade técnica' (2012). No texto, Benjamin demonstra como o uso da tecnologia (máquina) põe em prática o processo de reprodução em série. A reprodutibilidade técnica cria uma sucessão de valores sobre o objeto copiado repetidamente, subtraindo sua autenticidade e unicidade, ou seja, sua 'aura'.

Como nos mostra Benjamin (2012), com a litografia, a técnica de reprodução atinge um etapa essencialmente nova. $\mathrm{O}$ alcance de procedimentos mais precisos, permitiu às artes gráficas colocar de maneira inédita no mercado suas produções não somente em massa, como já acontecia anteriormente, como também sob a forma de criações sempre novas. Mais tarde, com a fotografia, pela primeira vez no processo de reprodução da imagem, a mão foi liberada das responsabilidades artísticas mais importantes, que agora cabiam unicamente ao olho. Uma vez que o olho apreende mais depressa do que a mão desenha, o processo de reprodução das imagens passa a experimentar tal aceleração que começou a situar-se no mesmo nível que a palavra oral, compara Benjamin. Com efeito, as startups, em grande medida, encontram na automatização de seus processos e nas dimensões imateriais do trabalho intelectualizado, caminhos para se tornarem replicáveis e escaláveis.

Gorz (2005) analisa que, se nas estruturas modernas de produção, a utilização proveitosa do conhecimento obtém seu sucesso por meio, sobretudo, da mobilização de um tipo de saber 
objetivado em máquinas, instalações e processos, hoje a capitalização do conhecimento detém uma nova fronteira. É o conhecimento passivo de formalização que, uma vez abstraído de seu suporte material e humano, pode ser multiplicado a custo irrelevante na forma de software e ser utilizado ilimitadamente em máquinas que seguem um padrão universal. Assim, quanto mais se propaga, mais seu valor mercantil diminui, em uma razão em que a sua propagação tende a zero. Logo, o conhecimento torna-se um bem comum acessível a todos.

o saber não é uma mercadoria qualquer, seu valor (monetário) é interminável; ele pode, uma vez que é digitalizável, se multiplicar indefinidamente e sem custos; sua propagação eleva sua fecundidade, sua privatização a reduz e contradiz sua essência. (GoRZ, 2005, p.59).

Os bens de informação oferecem evidências objetivas dessa análise. No século XX, pensar em alguns produtos audiovisuais, fonográficos ou de entretenimento como filmes, seriados, músicas e games, implicava diretamente em pensar suas relações com os grandes estúdios de produção, circuitos de distribuição, canais de exibição e direitos de propriedade. As atividades de criação, produção, distribuição e comercialização exigiam uma cadeia produtiva que se articulava através de uma complexidade física, estrutural, gerencial e estratégica, orquestrada, em grande medida, por relações hierárquicas e lineares de exclusividade, propriedade, controle dos meios, concentração de recursos e investimentos intensivos.

No século XXI, vivemos a emergência de novos players nesse mercado. Imersos em uma condição tecnológica que permite o fluxo contínuo da informação e sua transmissão em diversas arquiteturas e dispositivos por meio de conexão de dados ou conexão wireless, os serviços de streaming de vídeos, músicas e games, que oferecem como produto não a propriedade, mas o acesso a esses diversos tipos de conteúdo, vêm consolidando-se e provocando profundas transformações nos modelos de negócios que operam nesses mercados. Na obra A era do acesso, Rifkin (2005) analisa que, em paralelo às relações de propriedade típicas do capitalismo industrial, surgem relações baseadas no controle de acesso, contribuindo para a configuração de um ecossistema digital ancorado no relacionamento e no capitalismo cultural. Sua obra está atenta à dimensão imaterial dos produtos que leva vantagem sobre a realidade material, uma vez que o valor simbólico, estético e social prevalece sobre o valor de uso prático e valor de troca. 
Através de uma gestão de cadeia de dados digitais e da participação de tecnologia inserida na Computação em Nuvem, empresas como o Netflix ${ }^{71}$ e o Spotify $^{72}$, através dos protocolos de Internet por elas empregados, são capazes de transformar os diversos dispositivos de tela em serviços de Cinema on demand ou de uma rádio com acervo infinito e personalizado de músicas. Tudo isso sem possuir um exemplar físico desses produtos, sem delimitar o tempo e a espacialidade para a experiência do consumidor final, promovendo, assim, não só uma processo de mudança tanto do produto e da experiência de consumo, como também promovendo grandes alterações no modo como esses negócios se desenvolvem.

A emergência desses serviços apontam para um profundo processo de transformações em curso no modus operandi empregado para a criação e entrega de valor, bem como na própria engenharia dos negócios do século XXI. A complexidade desses negócios começava a demonstrar uma qualidade diversa dos modelos tradicionalmente consagrados dessa indústria. Esses modelos operacionais - que ainda guardam em si gênese dos modelos clássicos baseado na departamentalização, simplificação, fragmentação de tarefas individuais, estruturas lineares de produção em escala e na participação tecnológica voltada para otimização do trabalho e da produção, perdem espaço para modelos fluidos, ambientados numa espacialidade em fluxos e que se realizam pela formação de redes, manipulação de dados e pela realização de processos comunicativos.

Assim, o pensamento desenvolvido e a consequente estrutura montada para permitir a atuação sobre a matéria na geração de valor, bem como a presença de um tipo de participação tecnológica voltada, quase que exclusivamente, para a otimização do trabalho, da produção e do capital, são subvertidos quando inseridos em um contexto em que o processo comunicativo é deslocado para a posição central, sendo este a engenharia ou o próprio resultado do processo de produção. Nestes modelos de negócios, as tecnologias são incorporadas em uma relação não de uso ou instrumentalidade, mas como participantes fundamentais dos processos de concepção, produção, distribuição e consumo. São elas que potencializam os processos comunicativos e as trocas informativas, sem os quais esses negócios não se realizariam.

Para Castells (1999), é nesse potencial de aplicar o conhecimento e a informação para a geração de conhecimentos e dispositivos de processamento e comunicação da própria informação, em um ciclo de realimentação cumulativa entre a inovação tecnológica e o próprio uso da tecnologia, que a atual transformação tecnológica exibe a sua característica fundamental

\footnotetext{
${ }^{71}$ Disponível em: https://www.netflix.com/br/.Acesso em: 26 jun. 2016
}

72 Disponível em: https://www.spotify.com/br/. Acesso em: 26 jun. 2016 
de diferenciação. Essa transformação coloca, pela primeira vez na história, a mente humana como uma força direta de produção, não apenas um elemento decisivo no sistema produtivo. $\mathrm{O}$ efeito fundamental desse novo paradigma coloca a informação como produto do processo produtivo e coloca a ação do conhecimento sobre o próprio conhecimento como fonte de produtividade (ibidem).

Nos anos 90, o sociólogo francês Pierre Lévy (1996) já descortinava essa economia produzida em simbiose com as redes e as tecnologias de suporte digital. Em um exercício de reflexão, ele enfatiza a informação e o conhecimento como dois recursos-chaves da nova economia, ocupando esses uma posição de infraestrutura, de fonte ou de condição determinante para produção de todas as outras formas de riqueza, sendo o conhecimento e a informação os bens econômicos principais da nossa época.

As impactantes transformações vividas na indústria dos bens de informação como exemplificadas com o Netflix e o Spotify tornaram-se exemplos clássicos para ilustrar as consequências e o potencial produtivo dessa nova condição tecnológica comunicativa e suas implicações no âmbito da economia. Entretanto, as mudanças em curso não deixaram de acompanhar a crença inicial de que estaríamos diante de transformações que seriam efetivamente sentidas e limitadas à indústria da informação e ao âmbito da produção de bens intangíveis como observados na indústria da comunicação. Na obra Economia da Informação, Varian \& Shapiro (2003) realizam um esforço para mostrar como os princípios econômicos permanecem vivos e podem ser usados frente a essas mudanças trazidas pela Internet, e quais relações de correspondência adotar para lidar com uma economia onde a informação e conhecimento assumem a condição de centralidade.

Entretanto, como o próprio Castells (1999) assinala, diferente das transformações tecnológicas que ocorreram em séculos passados, o novo paradigma tecnológico da informação, baseado na comunicação, nos traz como uma das suas características marcantes a velocidade de desenvolvimento e aplicação de suas inovações. Assim, não demorou muito para acompanharmos o desenvolvimento de formas mais complexas de arranjos econômicos, fazendo-nos vislumbrar outras dimensões dessa profunda transformação econômica.

Nesse sentido, veríamos um negócio de transporte individual de passageiros ganhar dimensão mundial sem apresentar um veículo em seu ativo imobilizado ${ }^{73}$ ou um motorista como integrante do corpo social da empresa. O case já abordado, Uber, que se tornou a maior startup do mundo, tem como core business (atividade núcleo da empresa) comunicar pessoas, espaços,

\footnotetext{
${ }^{73}$ Refere-se ao conjunto de bens tangíveis necessários à manutenção das atividades da empresa.
} 
dispositivos, redes e mobilidade, realizando-se através de um conjunto de ações infocomunicacionais (LEMOS, 2013) produzidas pela relação sinérgica entre átomos e bits.

Dessa vez, os negócios pensados e concebidos no interior de um ecossistema comunicativo nos despertam para o potencial dos dispositivos tecnológicos de comunicação mais poderosos e refinados, para os espaços conectivos mais sensíveis e para as qualidades infocomunicacionais das coisas (LEMOS, 2013). Com isso, os fatores produtivos ${ }^{30}$ ganham novas espacialidades, nova matéria, nova temporalidade e novas dimensões. Ao acessar esses insumos informativos, os novos agentes econômicos acabam produzindo tipos de negócios outros, que se se realizam, essencialmente, por trocas infocomunicativas, processos de cooperação, acesso, conectividade e manipulação de dados.

Para o economista Jeremy Rifkin (2016), a força que impulsiona a configuração desses novos e disrutivos arranjos econômicos é o que por ele é chamado de "o fenômeno do custo marginal zero" 74 , possível de ser alcançado graças aos ganhos de eficiência e produtividade possibilitadas pelo advento das novas tecnologias digitais. Segundo ele, essa capacidade produtiva, já percebida na segunda fase da Internet conhecida como 2.0 (que nos permitiu reduzir dramaticamente os custos de produção, distribuição, comunicação, coordenação e assim criar produtos e serviços essencialmente livres como a Wikipédia), ganha novas dimensões quando conectada com a mais nova fase de expansão da Internet, a Internet of Things ${ }^{75}$, uma infraestrutura inteligente capaz de conectar tudo a todos em uma rede neural global. O potencial transformador desta infraestrutura denominada Internet das Coisas, ainda em escala de experimentação, expansão e descoberta, tem conectado tudo a todos e convergido tudo e todos em uma única plataforma operacional inteligente. Os sensores anexados em toda a cadeia de valor da economia incluindo seus pilares de energia, mobilidade e comunicação ${ }^{76}$, tem

\footnotetext{
${ }^{74}$ Custo marginal refere-se ao custo de produzir e distribuir unidades adicionais de bens e serviços.

75 Termo cunhado em 1999 por Kevin Ashton, cofundador da Auto-ID Center no MIT, a Internet das Coisas é, de acordo com CERP 2009 (Cluster of European Research Projects on the Internet of Things), uma infraestrutura de rede global dinâmica, baseada em protocolos de comunicação em que "coisas" físicas e virtuais têm identidades, atributos físicos e personalidades virtuais, utilizando interfaces inteligentes e integradas às redes telemáticas, constituindo-se assim um novo campo que reúne questões técnicas e sociais (LEMOS, 2009). O potencial da interconectividade de dispositivos, lugares e pessoas já ganha espaço na indústria e no comércio -controle de estoques, ações e marketing, criação de cidades inteligentes, pesquisa em animais, tratamentos médicos de controle e sistemas de segurança. Muito embora Rifkin (2016), em sua obra The marginal cost zero society alerte-nos para o trabalho em curso de algumas das companhias líderes em tecnologia da informação no desenvolvimento de infraestrutura de inteligência e criação de uma rede neural global - como General Electric's "Industrial Internet," Cisco's "Internet of Everything," IBM's "Smarter Planet," and Siemens's "Sustainable Cities", estes esforços ainda estão em processo de experimentação e exploração de potencial.

${ }^{76}$ Para Rifkin (2016, p.37), as plataformas econômicas ao longo da história sempre contêm três elementos, a saber: uma forma de comunicação, uma forma de energia e uma forma de mobilidade, responsáveis por mover a atividade econômica. No século XIX, na primeira revolução industrial, sua comunicação foi a imprensa e, mais tarde, o telégrafo. As formas de energia foram o carvão e a energia a vapor. Já a forma de mobilidade eram a locomotiva e as ferrovias. No século XX, nós também contamos com esses três componentes. A comunicação foi centrada na
} 
construído uma única infraestrutura econômica acessível, distribuída e constituída por bits e átomos. É nesta cadeia de valor da economia em forma de rede inteligente distribuída e conectada que o economista enxerga o potencial transformador capaz de nortear a recriação da economia através de uma relação territorial e comunicativa na produção de valor. Segundo ele quando nos movemos da tradicional Internet da Comunicação para a Internet das Coisas, ou seja, nos movemos de bits para átomos, nós ultrapassamos a limitação inicial do potencial produtivo das novas tecnologias apenas no âmbito da produção de bens de informação e caminhamos em direção à produção de bens físicos e energéticos.

A possibilidade de operar em uma infraestrutura/plataforma tecnológica global e acessar o big data proveniente de sensores acoplados ao longo de toda a cadeia de valor da economia contribui significativamente para que os consagrados papéis da economia tradicional de poucos produtores para uma massa consumidora passiva apresentem um incipiente processo de reorganização. Dessa massa consumidora surgem novos agentes que se deslocam para papéis ativos dentro da arquitetura econômica. Os novos idealistas, que com a Internet da Comunicação e a cooperação transformaram a oferta de informação, ganham maior potencial com a disponibilidade de uma infraestrutura que lhes permitirão operar em um completo fluxo de dados vindo de toda parte da economia, uma cadeia de valor cada vez mais digitalizada, em que, assim como na Internet tradicional de comunicação, todos possuem acesso ${ }^{77}$ quase que equitativo a banco de dados, às espacialidades, às arquiteturas, às inteligências e aos dispositivos para descobrir novas aplicações, exercer condição de agente e criar redes de inovação.

eletricidade, inicialmente o telefone e mais tarde o Rádio e TV. A forma de energia foi o óleo, e a mobilidade foi a máquina de combustão interna. Esta plataforma nos permitiu ter grande proveito da oportunidade econômica no século XX com a Segunda Revolução Industrial. A recente expansão da Internet, a Internet das Coisas, nos traz a Terceira Revolução Industrial. Nela, a forma de comunicação é a Internet. A forma de força é a energia renovável distribuída. As formas de mobilidade são os veículos automatizados e drones. Através desta brevíssima análise histórica, o economista visa demonstrar o papel fundamental que as novas tecnologias de informação, fontes de energia e modalidade de transporte desempenham em reorientar a dinâmica espaço-temporal, permitindo que o número maior de pessoas se reúnam em organizações sociais mais complexas e interdependentes. Estas plataformas tecnológicas não só constituem infraestrutura, mas também ditam a forma como a economia é organizada e gerenciada.

${ }_{77}$ Desde que seja mantida a neutralidade da rede. 


\section{PESQUISANDO NA ZONA CINZENTA}

- Neste capítulo, eu sou a própria idealista. Projeto uma ideia e lanço ao mar. Uma ideia 'anzol' para 'pescar'. Um jeito de quem se lança atrás de um trio para viver a vida na pele das coisas. Quero pescar na imensidão do mar, sem me perder numa navegação sem bússola. Mas também não posso deixar de ser cigana: aprender pelo sentir, perceber pelo viver no carnaval das coisas. Se me permitirem, quero usar o metro e o compasso sem me reduzir a ser o que não sou: a senhora do Procusto. Podemos também esconder o método, simplesmente dizendo-o como uma farsa. Ao andar, percorri. Ao conversar, percebi. Ao descobrir, entrei em profundos labirintos. $\mathrm{O}$ método não deixa de ser também uma zona cinzenta. Quero pedir licença para dizer que fiz a pesquisa querendo fazer uma Monalisa. Preciso dos 20 anos de Da Vinci para me corrigir.
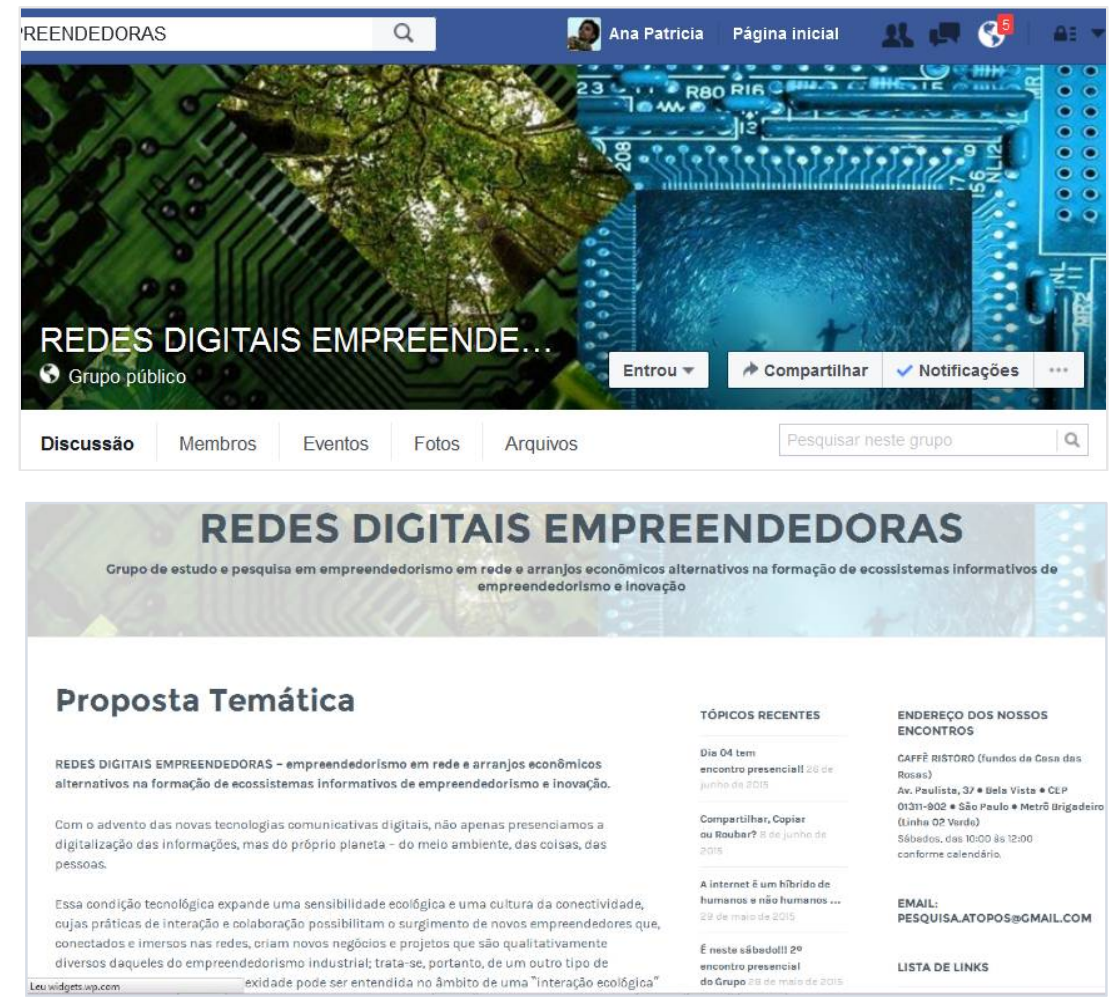

FIGURA 25. DISPOSITIVO DE PESQUISA ${ }^{78}$

Cogestão do Grupo de estudos e pesquisa em empreendedorismo em rede e arranjos econômicos alternativos na formação de ecossistemas informativos de empreendedorismo e inovação

78 Disponíveis em: https://www.facebook.com/groups/367002150124699/. Acesso em 27 jun. 2016 e https://redesdigitaisempreendedoras.wordpress.com/. Acesso em 27 jun. 2016. 
Quando as startups se tornaram objetos desta pesquisa, o ato de entender este processo emergente do mundo-rede produziu indagações sobre as materialidades que fundamentam a existência das startups, o seu ser em si. Eu indagava: a) o que nestas empresas nascentes me afeta para ser conhecido? b) que relação posso construir com o conhecível? c) que projeções (e modelagem) serão significativas produzir a partir dos conhecimentos desta pesquisa? Para abordar estas questões, a pesquisa necessitou situar no tempo presente os porquês das emergências desses empreendimentos e, então, fez um esforço em busca de suas (in)certezas.

O "tempo" das startups foi abordado a partir dos referenciais teóricos da pesquisa, com teorias sobre a hegemonia do trabalho imaterial, situando - digamos assim - seu fenômeno não como uma oposição entre o presente e o passado, uma "disputa" entre o velho e o novo. A pesquisa percebe uma profunda transformação das formas do viver, que podemos, por um esforço de síntese, chamar de arquitetura-rede. Deste tecimento novo emerge também o praticismo high-tech dos seres que chamo de 'novos idealistas' do mundo do empreendimento. Ao pesquisar suas ações, a arte do método se deparou com o desafio de adentrar no seu interior para conhecer suas práticas.

Como "marinheira" de poucas viagens, deparei-me com mares empíricos e teóricos. A princípio, abracei a ideia de inovação com rompimento. Mas ao adentrar no desconhecido para percebe "qual é de mesmo", as sangrias desatadas dos novos idealistas não se casam bem com o ideal de um rompimento - por deveras simpático - de que uma nova "América" está para nos surgir, diante de olhos esbugalhados de surpresas. Há algo novo, novíssimo e desagregador, no entanto o novo que emerge é o conhecimento como principal força produtiva.

O método "mora" neste território fluido. Como assinalam Guba e Lincol (2011, p. 69), "há muito tempo os cientistas sabem que o avanço da ciência nem sempre é ordenado" e “depende em grande medida de intuições, lampejos, 'sensações' ou experimentos mentais". Este conhecer-descobrir ocorre em coisas que não se categorizam. Coisas diversas em meio às multiplicidades de outras coisas. Os fatos só têm significados dentro de uma determinada dimensão valorativa. Portanto, as coisas ditas aqui não pretendem descrever "do modo como as coisas de fato são", porque, na verdade, se trata de uma produção atribuindo sentido às práticas dos 'novos idealistas' em suas startups em um ambiente particular, em um tempo novo que emerge e cujas dimensões só as percebemos em claros-escuros.

Aqui revelo meu intuito de produzir uma pesquisa como minha "Monalisa" com um rigor outro. Esta construção é, antes de tudo, o tecimento de uma interação com esses empreendedores e seus empreendimentos. Este tecimento é que é a "realidade" - limitada às percepções, aos valores atribuídos, ao dito ou maldito nos "cases" que permeiam em todos os 
capítulos deste relatório. Portanto, as percepções são fluidas, temporais, ocasionais. A avaliação está "objetivada" em ações em trânsito - nos movimentos de articulação dos seus produtos e modelagens.

Como produzi minha "Monalisa"? Com vivências e convivências. Com exemplos e exemplificações. Com um jogo de linguagens, conceitualizando linhas de desejos sobre o caos, que se apresentam como um aparente aparecer das coisas. Não me engessei em corpus. Ao contrário: busquei 'esgarçar' os cases, abrir os conceitos articulados pelos próprios idealistas, para tentar navegar nos movimentos das suas criações. Assim foram surgindo as percepções, assim fui nomeando passagens, assim fui expondo a coisa que me atina conhecer: a travessia dos novos idealistas na Zona Cinzenta. Na produção do método, a linguagem, a cartografia e também a intuição e a conceitualização pulsam como um "mix" na minha navegação. Um método é, portanto, tortuosos caminhos em alto grau de incerteza.

\subsection{COMPLEXIDADE E INCERTEZAS}

Ao iniciar o caminho de aproximação do 'objeto', existia dentro de mim uma certa busca inconsciente por 'lentes' que me auxiliassem a entender o fenômeno do empreendedorismo startup através de uma lógica de "arrumação", "linearidade", "sequências" - uma lógica tão familiar nos estudos de empreendedorismo e negócios, cuja ruptura se apesentou para mim como uma condição imprescindível, no meu também desejo de buscar outros voos, outras formas de pensar. Nesta empreitada, ao co-coordenar o grupo de estudos Redes Digitais Empreendedoras no Centro Internacional de Pesquisa Atopos ${ }^{79}$, cujas ambiências também compreenderam arquiteturas interativas como blog e redes sociais, encontrei caminhos e fiz reflexões que contribuíram para um rascunhamento deste percurso.

Deparei-me com velhos problemas de pesquisa que, no entanto, continuam resilientes: separação do sujeito observador do objeto observado, a relação entre o homem e a técnica, a frontalidade da pesquisa e a figura do pesquisador em contextos de rede de redes. Como assinala Di Felice, Torres e Yanaze (2012), a pesquisa que se desenvolve em contextos reticulares apresenta a impossibilidade da externalidade, ou seja, a impossibilidade de estudar a rede a partir de uma perspectiva externa ao observador e limitada às análises frontais de suas

${ }^{79} \mathrm{O}$ Centro Internacional de Pesquisa Atopos é uma rede internacional e interdisciplinar de pesquisa com sede na Escola de Comunicação e Artes da Universidade de São Paulo. Disponível em: www.atopos.usp.br. Acesso em 01 jan. 2016. 
arquiteturas informativas, fundada na unidirecionalidade e na separação identitária entre o emissor e receptor.

Assim, foi imersa nas redes da própria pesquisa, hóspede de arquiteturas digitais, realizando conexões, seguindo fluxos, acompanhando movimentos, observando e participando das articulações e dinâmicas nos ecossistemas comunicativos das startups, que tecemos a pesquisa. Ao percorrer caminhos mais invisíveis que visíveis, deixei estes movimentos se revelarem para mim em relações reticulares, rizomáticas e hipersensíveis. Percebi que não poderia traduzi-los em um processo de correspondência com conceitos e categorias do empreendedorismo tradicional ou até mesmo com base no empreendedorismo digital, abordado, em grande medida, com uma visão instrumental das tecnologias. As produções do empreendedorismo startup revelavam um além do resultado de um trabalho de migração. Tratava-se de uma nova corporalidade portadora de uma qualidade outra, imersa em um social outro e realizando um tipo de produção outra, portanto, diverso do empreendedorismo tradicional.

Desse modo, o imperativo era romper com estudos categorizantes que não dariam conta do perfil hologramático, recursivo, dialógico (MORIN, 2007) do objeto, e buscar caminhos de contraposição ao pensamento reducionista, linear e simplificador. Se apresentava então um incontornável caminho ao abandonar a tentativa de buscar situar um fato, fenômeno, processo, ou de buscar separações ou externalidades. Com efeito, a pesquisa parte do pressuposto que não há uma realidade "lá fora" a ser capturada, como se faz uma fotografia ou mesmo a compra de um software para produção de um aplicativo. Mas, pelo contrário, até mesmo em atos assim tão funcionais há uma intencionalidade, uma construção a ser produzida, um olhar, um recorte sobre uma determinada realidade tanto sobre a produção de uma foto quanto a realização de um dispositivo para transformações.

Então, a realidade é constituída por construções interativas. Por conseguinte, o que existe para comprar, conhecer, produzir, não está dissociado de valores, interesses, finalidades, conforme bem afirmam Guba e Lincoln (2011). Nessa perspectiva, como construir os métodos? Não há como omitir que ocorreram relações por demais contraditórias e mesmo com o que se afirma ser "falta de consistência" metodológica, uma vez que, em determinados momentos, pesquisei à parte, tentando buscar modelagens, como se houvesse uma realidade a ser capturada, fazendo uso de métodos intervencionistas - tentando estruturar a investigação. Esta busca incorreu no agenciamento de uma diversidade de meios para "entrar" no objeto e assim encontrar formas de gerar conhecimento. E, então, tanto quanto a zona cinzenta, os métodos mesmos caíram em suas "zonas” de (im)possibilidades. 
Ao criar meios para descobrir os aparentes apareceres do fenômeno startup, não me importei em distanciar-me e, ao mesmo tempo, em "contaminar-me" com a coisa. No entanto, quanto mais tentava isolar objetos para entender a realidade, mais o próprio objeto levava a pesquisa para "enrascadas" por logo desdizer o método ao apontar contradições e conflitos que se negavam a ser categorizados em blocos, como tradicionalmente se faz. A "gana" por explicar, apresentar e até mesmo prever levava-me a uma profunda angústia, uma vez que o fenômeno startup "teimava" em não se deixar apreender - o que na verdade obrigou-me a reiterar, reescrever, reanalisar, o que de fato opõe este texto a um texto-bíblia. Então, a construção metodológica desta pesquisa - com todas suas contradições e carências - levou em conta formas que exponham as diversidades de construções e, para tanto, uma implicação permanente entre objetividade e subjetividade.

Embora possamos construir televisões para o fenômeno - com conceitos abrangentes do tipo "zona cinzenta", quando se produz o foco, a televisão se desmancha em mosaicos de realidades. A não ser que se queira chamar de mosaico um todo, as startups resistem às identidades pré moldadas. Com isto, esta pesquisa diz que no fenômeno das startups: a) não existe uma realidade objetiva, reproduzível em escalas permanentes, engessadas em causaefeito; b) mas múltiplas realidades produzidas por indivíduos (jovens-geeks), mas também "senhores" de 40, 50 anos; c) não há como compreender as startups construindo e isolando um corpus de objetos e questões e desvinculando-se dos seus movimentos e mudanças-camaleão.

Abordar fenômenos como o das startups somente do ponto de vista do método científico, ou seja, de dispositivos consensuados nos meios universitários como 'pesquisa', significa perder seu caráter social, político e o movimento do próprio 'motor' destas novas organizações, que é sua fluidez. Então, o esforço aqui é por uma abordagem emergente não restrita à obtenção de fatos, fugindo às tentações dos gessos da mensuração, descrição, estipulação de juízo de valor definitivo. A pesquisa abdicou ficar presa a um "corpus" de pesquisa e se propôs seguir movimentos, acompanhando as articulações dos 'novos idealistas' em suas lides diárias. Em determinados momentos, apraz-me descobrir como, de fato, ocorrem as criações das startups por grupos, forjando seus territórios de poder-fazer na Zona Cinzenta. Diria que este acabou por se tornar o foco principal. Mas também a pesquisa busca entender o que de fato ocorre: a nova configuração das produções na arquitetura rede - isto porque passei a desconfiar da tese segundo a qual há um "desafio ao status quo" por meio dos sujeitos novos que produzem as startups.

Não satisfaz conceitualizar as diversas formas de abordagens da praxiologia das startups sob o signo de "multimétodos" - uma vez que este conceito aparenta uma apresentação de 
cardápios de métodos e ações hipermetrificadas, diga-se assim. Sem dúvidas que na construção dos conhecimentos sobre as ações desses seres - aqui chamados de 'novos idealistas' - numa fase profícua da construção das startup denominada de 'Zona Cinzenta', há todo um instrumental de métodos - da cartografia à grounded theory com construtivismo de conceitos.

Para Tarozzi (2011) a teoria fundamentada (grounded theory) é uma metodologia de pesquisa que permite a análise dos dados qualitativos por meio de um conjunto de procedimentos próprios. Grounded, pode significar simultaneamente enraizado, embasado, encravado e firme à terra. “(...) é um enraizamento vital na experiência dos fatos, forte, intenso, às vezes até violento. (...) é o enraizamento vivido nas vísceras da realidade" (TAROZZI, 2011, p.20), o que consiste à teoria elaborada, um valor prático-operativo e útil para aos seus operadores, completa. Ele nos aponta duas características essenciais da metodologia: (i) "a possibilidade que oferece de construir categorias analíticas a partir dos dados e, por conseguinte, respeitar os fenômenos seguindo as indicações que provêm do mesmo" (IBIDEM, 13); (ii) a possibilidade de conjugar pesquisa empírica com reflexão teórica.

Com efeito, a pesquisa transitou por uma diversidade de caminhos: i) produzindo conceitos que emergiram mesmo das próprias falas dos novos idealistas por meio de codificações abertas a partir dos cases que perpassam por todo o texto; ii) analisando discursos, como no método jornalístico por meio entrevistas abertas, depoimentos, contatos online e iii) acompanhando processos, observando linhas de desejos e as redes que estes desejos nos momentos de ideação e experimentação.

Mas os dispositivos de descobertas, entendimento, escavações ocorreram também - de uma forma não tão bem descrita aqui - por meio de caóticos procedimentos de percepções em atenção às coisas mínimas - sentimentos, pequenas conclusões, ações colaborativas em rede que acontecem nas relações com as linguagens, os contatos, as trocas de experiências. Quando se afirma que estas coisas mínimas "não são tão bem descritas" é porque de fato foge à linguagem o caos das compreensões, descobertas, conclusões que ocorrem por fora dos nossos métodos... Exemplo: me indagava por que me ocorreu retornar e fazer acompanhar startups residentes do espaço Co-working Cubo, em São Paulo, justo quando me encontrava no meio desta pesquisa. Por acaso, os meus dados não me eram suficientes? Eu não já estava com uma intensidade de informações que me davam segurança sobre o "objeto"? Em respostas a estas questões posso afirmar: sim!

No entanto, algo em mim me disse para sentir na pele o que os olhos, o ouvido, a boca articulavam juntos com meus pesquisados e suas máquinas de produção. Por mais que a 
pesquisa oferecesse informações sobre a zona cinzenta, mais sentia necessidade de viver na pele as "vidas" desse conceito que se tornou central nos processos avaliativos.

Tentando ser mais substantiva, apresento nos dois últimos subtópicos deste capítulo, os dispositivos metodológicos desta pesquisa, relatando seus trânsitos, paragens e os movimentos das idas e vindas, escavando o fenômeno das startups no que chamo de zona cinzenta. Neste movimento inicial a possibilidade de pensar o contexto de pesquisa como um conjunto de interações ecossistêmicas e de contínuas conexões entre coisas, bem como pensar o próprio fenômeno aparente como processos comunicativos reticulares, me ofereceu alternativas no modo de investigação e uma nova postura na pesquisa.

Assim, pude acompanhar o movimento, a circulação da ação e a fluidez das mediações que compõem as diversas dimensões do meu objeto, que se revelava como um contínuo devir de processos e conexões. Tal movimento levou-me a considerar meu objeto de estudo como um agenciamento de sujeitos, tecnologias e espaços, cuja composição resulta das dinâmicas de atores em rede, relações sociais e circuitos comunicacionais. Diante disso, entendi a necessidade de adotar teorias capazes de pensar o híbrido, pensar o tecido junto.

Como nos contextualiza Di Felice, Torres e Yanaze (2012), o pensamento complexo é contemporâneo de um período de intensa atenção à necessidade de pensar um tipo de conhecimento científico que não reduzisse a complexidade à simplicidade, ou seja, a uma forma sistêmica, mas que a produção científica fosse por si própria complexa, assim como a realidade observada. É dentro desta discussão, que os pesquisadores nos apresentam a ideia de pensar o contexto de rede de redes e os estudos realizados em contextos relacionados à comunicação digital através da complexidade reticular - esta última definida como uma nova forma de complexidade, capaz de explicar os fenômenos a partir de uma lógica não mais linear e frontal, mas reticular e interdependente. Tal perspectiva nos proporciona pensar no advento de uma razão conectiva que tende a explicar o mundo não mais a partir de linguagens separatistas e opositivas, mas por meio de uma lógica conectiva que buscam os elos de interdependência e da explicação conectiva, evidência de uma inteligência reticular ${ }^{80}$.

Assim como o meu percurso inicial desta pesquisa me fez reformar o modo de pensar, creio que a pesquisa em rede exige de nós também vieses novos para produzir conhecimento. Com efeito, Morin e Le Moingne (2000) afirmam que a atitude mais significativa do pensamento contemporâneo é justamente reformar o modo de pensar - e este não tem sentido

\footnotetext{
${ }^{80}$ Material audiovisual referente à pesquisa Redes Digitais e Sustentabilidade, realizada pelo Centro de Pesquisa Atopos (ECA/USP), com patrocínio máster da Petrobrás e apoio institucional da ECA/USP, disponível em: https://www.youtube.com/channel/UCVT7GXnGQBTcYNiXZFF9fvg, acesso em 15 jun. 2016.
} 
se não se reformar os modos de agir - indo além dos pilares do pensamento clássico baseado na ordem, na separabilidade e na razão.

Assim, busquei entender o fenômeno das startups digitais nos trânsitos, nas fluidezas, nas conexões. Mais que apreender estruturas, busquei os movimentos rizomáticos, as interações, as relações reticulares com intensa observação de processos, participação, produção de conceitos e interação com seus próprios movimentos nas arquiteturas. Nesta perspectiva entendemos que a análise de qualquer objeto imerso neste contexto requer o risco de assumir procedimentos mais abertos.

\subsection{ACOMPANHANDO PROCESSOS}

No primeiro momento, tomei a minha atividade empírica de pesquisa como um objectil - ou seja, uma viagem que apruma seu foco com a própria emergência das visões, através de variedades de atenções, como assinala Kastrup (2009): “o rastreio", “o toque”, "o pouso" e o "reconhecimento atento". Das primeiras varreduras nos ecossistemas comunicativos das startups às vivências nas ambiências presenciais (também redes) de suas criações, os movimentos desta pesquisa, desde o início, não foram orientados à busca por uma informação pontual, mas, sim, um esforço para a "produção dos dados" da pesquisa.

Como Kastrup (2009, p. 49) nos alerta, a referência que aqui fazemos à "produção de dados" e não à "coleta de dados" não exprime uma mera tentativa de evitar o vocabulário tradicional, mas carrega em si uma proposta de uma mudança conceitual, objetivando nomear, de maneira mais clara e literal, práticas de pesquisa que se distinguem daquelas da ciência moderna cognitivista. Assim, quanto à etapa tradicionalmente denominada "coleta de dados", do ponto de vista dos estudos recentes sobre a cognição numa perspectiva construtivista:

(...) não há coleta de dados, mas, desde o início, uma produção dos dados da pesquisa. A formulação paradoxal de uma "produção dos dados" visa ressaltar que há uma real produção, mas do que, em alguma medida, já estava lá de modo virtual ${ }^{81}$ (KASTRUP, 2009, p.33).

\footnotetext{
${ }^{81}$ Kastrup (2009, p. 33) nos que o conceito de virtual nesta deblaração é empregado no sentido que lhe confere $H$. Bergson (1897/1990; 1919/1990). O virtual se atualiza segundo um processo de criação e de diferenciação. Nesse direção, distingue-se do possível, que se realiza através de um processo de limitação e de semelhança. Para a distinção detalhada entre virtual-atual e possível-real cf. Deleuze (1966). Podemos tomar como exemplo da atualização de uma virtualidade - como produção de algo que já estava lá - a produção das mãos de um pianista através de repetidos treinos.
} 
Com uma atenção aberta e sem focalização específica, os primeiros gestos de rastreio visavam um alvo móvel. Imersa em seus ecossistemas comunicativos, habitando em suas arquiteturas em rede, realizava movimentos flexíveis no acompanhamento de mudanças contínuas de posição, velocidade, aceleração e ritmo, captando não apenas elementos que formam textos coerentes, mas também elementos desconexos e em desordem caótica.

Em realidade, entra-se em campo sem conhecer o alvo a ser perseguido; ele surgirá de modo mais ou menos imprevisível, sem que saibamos bem de onde. Para o cartógrafo, o importante é a localização de pistas, de signos de processualidade (KASTRUP, 2009, p.40).

Ao realizar movimentos um tanto quanto aleatórios de passe e repasse em uma exploração assistemática do terreno, tenho minha atenção tocada. Uma rugosidade, um destaque no conjunto inicialmente homogêneo de elementos observados. O toque, em primeira mão, acionou o processo de seleção, surgindo as primeiras intenções sobre os campos de atenção e o primeiro pouso no território. Em meio às questões dessa pesquisa, interessava-nos saber quem eram aqueles criadores de startup? O que eram aquelas criações? Como de fato ocorriam as suas construções? Era preciso extrapolar as conexões em fios e redes e adentrar as suas ambiências presenciais conectadas. A pesquisa, até então online, passa a transitar também para o presencial, momento em que acontecem os encontros e acionamentos no nível das sensações (ibidem, p. 42).

Nesse momento decidimos experenciar vivências em um contato direto com as startups e seus territórios existenciais. Para isso, adentramos o CUBO CO-WORKING, um espaço compartilhado para startups na cidade de São Paulo e uma iniciativa do banco Itaú Unibanco. Chegamos em sua fase inicial de funcionamento em que este espaço abrigava cerca de 50 startups, a grande maioria em seus estágios iniciais de maturidade. Com efeito, ao habitar este território e produzir uma observação participante com as startups residentes, o espaço CUBO CO-WORKING funcionou como 'portas de entrada-saída' para as primeiras problematizações. Interessada em acompanhar processos e não representar um objeto, convivi com aqueles fazedores nas sangrias de suas criações, entrando pelos meios de seus processos em curso, entre pulsações (ibidem, p, 10).

Os encontros despertaram-me para a criticidade do alto grau de incerteza experenciado pelas startups em seu estágio de criação (estágio inicial), revelando-se como o momento de grande fertilidade para a produção de caminhos para pensar o fenômeno das startups digitais. Ao investigar os processos - aqui entendidos não como processamento, mas como processualidade, cujo objetivo é a investigação de processos de produção de subjetividade - 
estes guardavam em si elementos que subsidiavam a produção de conhecimento sobre a singularidade do empreendedorismo startup, em suas criações e dimensões.

A fase inicial das startups em suas ausências de modelos, em suas tendências a uma não definição, suas diversidades e transformações contínuas acabavam por descortinar os seus movimentos emergentes, incertos e multi. Sobre as startups digitais, não se tem nada pronto ou acabado, sendo preciso construir. A circunstância nos parecia favorável, uma vez que no território não existiam caixas-pretas ${ }^{82}$. Como Bruno Latour (2000, p.14) nos assinala ao discorrer sobre postura construtivista para desvelar a complexidade dos mecanismos que operam a produção do conhecimento cientifico, recomenda-se entrar em fatos e máquinas enquanto estão em construção e observar o fechamento das suas caixas-pretas, estudando assim a ciência em ação e não a ciência pronta (IBIDEM, 2000, p. 14).

Ao acompanhar suas conexões com o mundo e desenhar a rede de forças à qual as startups se encontram conectadas, percorrendo suas modulações e seus movimentos, a pesquisa se depara com seus criadores, que habitam seus territórios existenciais, sendo eles mesmos a própria startup. Em sua fase embrionária, as startups e seus criadores estão imbricados. As histórias, experiências e desejos de seus criadores se confundem com as previsões e projeções de suas criações. Assim, acompanhar os processos de criação das startups em seu early stage (estágio inicial) é acompanhar as ações de produzir e produzir-se dos seus criadores e suas vidas como business.

Neste momento de concepção, em grande medida, as startups são os seus próprios criadores, mergulhados em atividades ainda não automatizadas, experenciando modelos, e buscando fit com o mercado. Embora sejam o front da descoberta e criação, esses criadores não realizam suas produções por si mesmos, eles são redes em ação, tecendo processos, configurando movimentos diversos. No contexto das suas redes emergem outras redes que juntas compõem um ecossistema pelo qual as startups e seus criadores transitam em suas atividades de produzir e produzir-se.

Com efeito, o gesto de pouso reconfigurou o campo de observação, a percepção realizou uma parada e o campo se fechou, numa espécie de zoom. Um novo território se formou, o campo de observação se reconfigurou e a atenção mudou de escala. Em um gesto de reconhecimento atento, voltei-me ao que estava acontecendo e percebi uma travessia dramática

\footnotetext{
${ }^{82}$ A expressão caixa-preta é usada em cibernética sempre que uma máquina ou um conjunto de comandos se revela complexo demais. Em seu lugar é desenhado uma caixinha preta, a respeito da qual não é preciso saber nada, senão o que nela entra e o que dela sai. (LATOUR, 2000, p.14). Na ciência, as caixas-pretas representam conceitos e instrumentos de uma dada disciplina cientifica que alcançaram a posição de objetos teóricos aceitos pela comunidade cientifica.
} 
de seus criadores para colocar em execução as suas ideias e criar suas startups. Assim, aprumei o meu foco nas ações destes criadores nessa travessia, atenta aos conceitos que pulsavam nesse território de incertezas, procurando, a partir de um enraizamento com o conhecimento produzido nesta escavação-observação, construir microteorias explicativas capazes desse tipo de empreendedorismo outro.

O acompanhamento de processos por meio de diagrama-rede exigiu um tecimento sobre a multiplicidades das coisas e acompanhamento de fios que nos conectaram com redes e mais redes, ultrapassando o referência espacial inicial e não pondo limites ao campo, mas nos fazendo navegar em movimentos através de variedades de atenções em uma sequência não ordenada, de maneira caótica, complexa e contraditória.

Procurando assegurar um outro rigor, sem abrir mão da imprevisibilidade do processo de produção do conhecimento intrínseco à investigação, realizamos entrevista qualitativa intensiva, incialmente com startups residentes do espaço CUBO CO-WORKING e posteriormente com startups e agentes do ecossistema de startup de São Paulo. Ao habitar os territórios online das startups, foi realizada também a produção de dados a partir de entrevistas extraídas de material audiovisual produzido pelos próprios agentes do ecossistema em suas ambiências comunicativas em rede. Assim, a produção de dados preponderantemente verbais ocorreu a partir de duas fontes: entrevista qualitativa intensiva e documentos audiovisuais produzidos pelos agentes do ecossistema startup.

\section{- ENTREVISTA QUALITATIVA INTENSIVA}

Método que permitiu uma análise detalhada das experiências e tópicos relevantes do fenômeno das startups digitais, criando subsídios para a produção de uma investigação interpretativa. Com efeito, a entrevista intensiva é uma conversa direcionada. A natureza detalhada de uma entrevista intensiva promove o esclarecimento da interpretação de cada participante sobre a sua própria experiência (CRARMAZ, 2009, p, 46). Uma conversação focada em um objetivo que consente uma exploração em profundidade de um certo tema e faz emergir o modo através do qual um participante dá sentido à própria experiência, representando não um instrumentos para recolher "fatos", mas sim para gerar interpretações de experiências e colocar sempre as afirmações no contexto que as gerou (TAROZZI, 2011, p. 113). O trabalho de produção de informações com a entrevista intensiva foi realizado conforme os seguintes momentos, não necessariamente de maneira rigorosamente sequencial: 
a. discussão e elaboração de um roteiro de perguntas abertas para orientação da entrevista: este roteiro foi realizado individualmente para cada entrevistado especifico, atento ao equilíbrio entre a realização de entrevistas abertas e a concentração de foco nas afirmações significativas, buscando a provocação e discussão e detalhamento dos tópicos e estimulando o entrevistado a descrever e refletir sobre suas experiências. As questões que se repetem no roteiro subsequente são intencionais, visando ampliar as propriedades de categorias conceituais que emergiram das falas dos entrevistados anteriores.

b. realização do encontro-entrevista: as entrevistas foram realizadas presencialmente e também via Skype e e-mail, sempre com gravação em áudio. Durante a entrevista, foram registradas também informações de natureza observacional, informações objetivas e impressões que emergiram das experiências.

c. processo de transcrição: as entrevistas foram transcritas para a construção de categorias conceituais em um esforço para reduzir em código linguístico verbal toda a comunicação complexa (linguístico, paralinguístico, sociocultural) que ocorreu nas vivências dos espaços das startups e das conexões com os participantes (TAROZZI, 2011, p. 120). Nesse momento, foi realizado um trabalho interpretativo, em que selecionamos e classificamos as informações produzidas, para iniciarmos um aprofundamento de uma interpretação analítica sobre os conceitos que pulsaram nestes contextos e desenvolver as noções teóricas para a interpretação de cada segmento coletado.

\section{- PRODUÇÃO COM FONTE DOCUMENTAL}

O trabalho de produção de dados a partir de documentos ocorreu de maneira complementar às entrevistas intensivas realizadas. Estas deram conta diretamente dos processos em ato, da observação direta e captação de nuanças relevantes. A produção de dados foi útil no momento de ampliação das propriedades e dimensões dos conceitos que emergiram (ver 5.3), essencialmente, nas entrevistas e anotações observacionais produzidas pela pesquisadora nas entrevistas e anotações durante o acompanhamento de processos. Esse momento da pesquisa permitiu uma intensa imersão no material audiovisual produzido pelos agentes do próprio ecossistema de startups. São eles: 
a. MAN IN THE ARENA: arena videocast sobre empreendedorismo e cultura digital apresentado pelos empreendedores Leo Kuba e Miguel Cavalcanti;

b. CANAL ENDEAVOR BRASIL: série de webdocumentários VAI QUE DÁ - A cara das startups brasileiras;

c. TV SEBRAE: Divulga vídeos curtos, webséries e troca de experiências entre empreendores. O Sebrae-SP é uma instituição sem fins lucrativos coordenada por representantes da iniciativa privada e do setor público, com o objetivo de estimular e promover o desenvolvimento do empreendedorismo e das empresas de micro e pequeno porte no Estado de São Paulo.

Inicialmente não houve uma preferência pelo acompanhamento específico de determinadas startups. Habitando territórios online e presenciais, sempre aberta aos movimentos e as variáveis em conexão, o conhecimento foi sendo produzido, essencialmente, em torno das falas e experiências dos agentes e das startups diversas. No Quadro 01, página 106, apresentamos as ambiências de análise.

\subsection{ANÁLISES COM PRODUÇÃO DE CONCEITOS}

Como analisar os dados produzidos pelas informações observáveis, entrevistas intensivas, vivência com as startups e moradas em suas arquiteturas comunicativas em rede? Recorri a uma análise por meio do desenvolvimento de conceitos capturados da própria produção de dados. Gallo (2013) nos explica que a criação de conceitos consiste em um pensamento direcionado criado a partir de um problema ou de uma conjunto deles, sendo uma forma racional de equacionar este problema, imprimindo uma visão coerente do vivido. Para ele o conceito nunca é dado de antemão, mas é sempre criado.

Sua etimologia está na própria noção de concepção: dar vida, trazer à luz. Com efeito, os conceitos pulsam nas entrevistas, nos vídeos, nos processos produtivos em insights. No primeiro momento, em amplos códigos. Depois em composições a partir das suas propriedades e dimensoes. Não pretendemos com estes conceitos construir universalizações, mas, sim, construir com eles um tecimento que subsidie o nosso exercício de reflexão sobre o empreendedorismo startup em seus momentos primários de concepção. Como afirma Gallo (2013, p. 55), “os conceitos nunca são conclusivos, mas continuam carregando em si os 
problemas que lhe deram origem, além de contribuírem para o aparecimento de novos problemas".

Assim sendo, no primeiro momento, fui à busca de conceitos que pulsavam com mais intensidade em torno do objeto, seguido de um esforço para encontrar suas propriedades, suas dimensões e possíveis variações, bem como nomeá-los. No processo de conceitualização houve uma preocupação com o enraizamento nos dados produzidos. A captura de conceitos em torno do objeto e a busca por dar nomes às coisas foram ancoradas na comunicação complexa com os participantes que ocorreu nos mais diversos planos comunicativos - linguístico, paralinguístico, proxêmico, cinético, sociocultural. Com efeito, as palavras dos participantes me ajudaram a dar nomes às coisas - uma estratégia que ajuda a preservar a riqueza de significado que os participantes designam ao seu próprio agir e às próprias visões e que ajuda a me prevenir dos riscos de enrijecimento dentro de um léxico técnico e acadêmico (TAROZZI, 2011).

Sem roteiros interpretativos dados a priori para analisar, exploramos analiticamente as informações produzidas. Nas falas, identificamos categorias conceituais capazes de explicar ideias, eventos ou processos que aprumaram o nosso foco e que geraram conceitos. Dessas categorias identificadas, demos a elas uma definição conceitual e um tratamento analítico. Um necessário processo de imersão para entrar em um plano conceitual e buscar linha de coerência entre os dados produzidos, bem como identificar unidades de sentido que dizem algo ao fenômeno estudado ou abrem outras questões ou intuições teóricas. A partir destas análises interpretativas, surgiu o principal conceito organizador, a zona cinzenta, que veio a se tornar a categoria conceitual central da nossa pesquisa.

\section{a. A zona cinzenta}

Representa um transcurso fluido, passageiro e dramático percorrido pelas startups na sua fase mais turbulenta de realizações. O abismo entre a ideia e a execução, onde a startup experencia o seu momento mais difícil de concepção ao produzir caminhos incertos, imprevisíveis, não lineares, nos quais, efetivamente, ocorre a realização (ou não!), vivenciando, assim, a maior criticidade do grau de incerteza na criação das startups. 


\section{b. Novos idealistas}

Seres híbridos com alta escolaridade, juventude e desprendimento. Do ponto de vista pessoal, destacam-se como seres apaixonados, sem senso de hierarquia, mobilizados para a ação por meio de autorias coletivas em protagonização com um mundo da multiplicidade, das conexões, de permanentes agenciamentos. Os novos idealistas são sujeitos-redes, motores de uma máquina revolucionária de movimentos de idealizações.

\section{c. Ponto de ideação}

Momentos iniciais da zona cinzenta em que os novos idealistas se preparam para lançar-se rumo ao inexplorado e desconhecido para perceber se sua ideia é relevante. Aqui concentram-se as ações no sentido de uma 'previsão' do produto a ser construído, um afazer. Trata-se de uma praxeologia no entorno de uma criação que só aparentemente se expõe como fenômeno.

\section{d. Ponto de experimentação}

Momento de alta aprendizagem que singulariza as startups quando comparada aos empreendimentos iniciais no mercado tradicional. Estágio que exige múltiplas interações e flexibilidade para mudanças rápidas e muitas vezes radicais. Uma intensa dinâmica de produção de redes que alimenta ações de cocriação e acaba por gerar um certo padrão de produção - na prática, uma linha de ação sobre o caos. Nela, o idealista realiza o esforço para entender melhor a sua ideia, fazer adequações em suas propostas de serviço/produto e descobrir como transformar suas 'prévisões' em um negócio que seja sustentável, reduzindo assim os riscos envolvidos na atividade. 
QUADRO 1.

AMbIÊnCIA de ANÁLISE |

\begin{tabular}{|c|c|}
\hline NOVOS IDEALISTAS & BREVE DESCRIÇÃo \\
\hline $\begin{array}{l}\text { FLÁVIO PRIPAS } \\
\text { https://cubo.network/ }\end{array}$ & $\begin{array}{l}\text { Co-working para startups de tecnologia: associação } \\
\text { sem fins lucrativos de fomento ao empreendedorismo de } \\
\text { tecnologia na cidade de São Paulo. }\end{array}$ \\
\hline $\begin{array}{l}\text { - EDUARDO L'HOTELLIER } \\
\text { https://www.getninjas.com.br// }\end{array}$ & $\begin{array}{l}\text { Marketplace horizontal: Plataforma de intermediação que } \\
\text { conecta os usuários a profissionais para a contratação de } \\
\text { serviços locais. }\end{array}$ \\
\hline $\begin{array}{l}\text { RICARD KAUDOAKI } \\
\text { https://prosas.com.br/ }\end{array}$ & $\begin{array}{l}\text { Conexão no terceiro setor: Plataforma que conecta os } \\
\text { atores da cadeia de valor de investimento social, } \\
\text { selecionando e monitorando projetos no setor. }\end{array}$ \\
\hline $\begin{array}{l}\text { - ROSI RODRIGUES } \\
\text { http://c.iugu.com/ }\end{array}$ & $\begin{array}{l}\text { Inf raestrutura financeira para startup: soluções } \\
\text { financeiras desenhadas para as demandas particulares dos } \\
\text { novos modelos de negócios digitais }\end{array}$ \\
\hline $\begin{array}{l}\text { JOÃO ABUSSAMRA NETO } \\
\text { http://www.wairon.com// }\end{array}$ & $\begin{array}{l}\text { Economia compartilhada: Plataforma que conecta } \\
\text { usuários a prestadores (microempreendedores individuais) } \\
\text { de serviços de lavanderia. }\end{array}$ \\
\hline $\begin{array}{l}\text { MARCIO BORUCHOWSKI } \\
\text { https://educarebr.com.br/ }\end{array}$ & $\begin{array}{l}\text { Tecnologia para a educação: ambiente de ensino a } \\
\text { distância individualizado que atende demandas pontuais de } \\
\text { alunos, especialmente do ensino fundamental e médio. }\end{array}$ \\
\hline $\begin{array}{l}\text { JORGE VARGAS NETO } \\
\text { https://biva.com.br/ }\end{array}$ & $\begin{array}{l}\text { Financiamento entre pessoas: Plataforma conecta projetos } \\
\text { com pessoas interessadas em realizar investimento com } \\
\text { rendimento superior ao oferecido pelos bancos. }\end{array}$ \\
\hline $\begin{array}{l}\text { MARCOS GOMES } \\
\text { http://boo-box.com/ }\end{array}$ & $\begin{array}{l}\text { Impulsão de vendas por click: tecnologia de publicidade } \\
\text { e mídias sociais que permite produtores de conteúdo } \\
\text { independentes rentabilizar seus blogs, sites e redes sociais. }\end{array}$ \\
\hline $\begin{array}{l}\text { DANIEL WJUNISKI } \\
\text { http://www.minhavida.com.br/ }\end{array}$ & $\begin{array}{l}\text { Portal de conteúdo: organiza e democratiza conhecimento } \\
\text { de saúde e bem-estar disponibilizando-o de maneira fácil e } \\
\text { acessível a todos. }\end{array}$ \\
\hline $\begin{array}{l}\text { FERNANDO OKUMURA } \\
\text { https://kekanto.com.br/sp/sao-paulo }\end{array}$ & $\begin{array}{l}\text { Inteligência coletiva: plataforma que reúne avaliações, } \\
\text { opiniôes e dicas de usuários a respeito de milhares de } \\
\text { estabelecimentos, organizando a cidade em um só lugar. }\end{array}$ \\
\hline $\begin{array}{l}\text { TALLIS GOMES } \\
\text { http://www.easytaxi.com/br/ }\end{array}$ & $\begin{array}{l}\text { Mobilidade por clicks aplicativo de táxi, conecta } \\
\text { passageiros e taxistas de forma rápida com uso do } \\
\text { smartphone e o mecanismo de geolocalização. }\end{array}$ \\
\hline $\begin{array}{l}\text { - SAMIR IÁSBECK } \\
\text { https://www.qranio.com/ }\end{array}$ & $\begin{array}{l}\text { Gamificação: plataforma de perguntas e respostas que } \\
\text { alinha aprendizado e diversão. São oferecidos quizzes sobre } \\
\text { diferentes temas e o usuário troca acertos por prêmios. }\end{array}$ \\
\hline $\begin{array}{l}\text { - HORÁCIO POBLETE } \\
\text { http://ledface.com/ }\end{array}$ & $\begin{array}{l}\text { Cocriação: site responde perguntas do dia a dia a partir da } \\
\text { cocriação de uma resposta personalizada produzida por } \\
\text { uma inteligência coletiva em rede. }\end{array}$ \\
\hline
\end{tabular}




\section{A ZONA CINZENTA}

O conceito de zona cinzenta foi produzido para exploramos a criticidade do grau de incerteza na criação das startups em seu estágio embrionário. A zona cinzenta é, de fato, o momento mais difícil da concepção da startup. É o momento em que os novos idealistas acreditam na sua ideia e investem seu tempo e dinheiro para prová-la. Para os empreendedores startup, mais do que descobrir um gap, uma oportunidade de negócio, eles buscam identificar um propósito para empreender. Esta busca está nos "precipícios" dos abismos da zona cinzenta.

O conceito pulsa também nos estudos realizados em 2012 pela equipe do Núcleo Fundação Dom Cabral de Inovação e Empreendedorismo sobre as Causas da Mortalidade de Startups Brasileiras ${ }^{83}$, em busca das razões que determinam a falência, em pouco tempo, da maioria das startups criadas no país. A pesquisa analisou o tempo médio de sobrevivência de uma startup no Brasil. Segundo o estudo, pelo menos $25 \%$ são descontinuadas antes do primeiro ano de vida, justo na travessia da zona cinzenta.

De fato, consideramos a zona cinzenta como o abismo entre a ideia e a execução. Nesta fase de grande complexidade e dúvida, ocorre um protagonismo com o acionamento de conhecimentos, meios de comunicação e afetos que se consolidam como um corpo sem órgãos ${ }^{84}$ para a travessia. Neste estudo, interessa-nos explorar como os novos idealistas acionam este corpo nos momentos iniciais de concepção de suas startups. Para extrairmos dados de maneira mais acurada, seccionamos a zona cinzenta em dois pontos distintos assim definidos:

- Ponto de ideação. Nele o empreendedor parte de um ponto inicial que é uma ideia, atrai pessoas, faz as pessoas acreditarem e contribuírem para a sua visão empreendedora. É um momento em que os novos idealistas se preparam para lançarse rumo ao inexplorado e desconhecido para perceber se sua ideia é relevante. Nestes momentos iniciais da zona cinzenta, o idealista é também um propagador, um

\footnotetext{
${ }^{83}$ Foram coletados dados quantitativos por meio de uma pesquisa que se valeu de um questionário online enviado a fundadores e cofundadores de startups no Brasil. A pesquisa totalizou uma amostra de 221 respondentes, sendo que 130 foram de empresas ainda em operação e 91 de empresas descontinuadas. A amostra foi dividida em dois perfis de respondentes, sendo: (1) Fundadores de startups brasileiras que tiveram suas startups descontinuadas e (2) Fundadores de startups brasileiras que ainda estão atuando no mercado. A pesquisa é intitulada Causas da Mortalidade de Startups Brasileiras: O que fazer para aumentar as chances de sobrevivência no mercado? Disponível em https://www.fdc.org.br/blogespacodialogo/Documents/2014/causas_mortalidade_startups_brasileiras.df. Acesso em: 01 jun. 2016.

${ }^{84}$ Deleuze e Guattari trabalham com o conceito de ‘corpo sem órgãos' nas obras Mil-Platôs e Anti-Édipo, tomandoo de empréstimo de Antonin Artaud para pensar um corpo não instrumentalizado de pura intensidade.
} 
produtor auto-marketing, agindo geralmente na total informalidade, contracenando em aberto com outros criadores ou potenciais parceiros.

- Ponto de experimentação. Momento de alta aprendizagem que singulariza as startups quando comparadas aos empreendimentos iniciais no mercado tradicional. Isso porque sem referências precedentes que ofereçam condições de replicabilidade, as startups neste momento realizam um esforço para descobrir qual o seu produto, qual precificação, qual modelo de negócio e mercado-alvo, antes de partir para a execução de suas atividades. É a busca pelo alcance da validação do produto e da descoberta da modelagem ideal para operação e criação de valor.

A delimitação destes dois pontos compreende o momento que precede a $1^{\mathrm{a}}$ etapa de 'busca' (search) do ciclo de startups sugerido pelos estudos de Blank (2016) e perpassa essa fase primária até o limite do estágio subsequente de maturidade dessas startups, em que seus esforços estão concentrados na 'execução' (build). Conforme abordado de maneira detalhada no Capítulo 3 (subtópico 3.3) da pesquisa, essa primeira etapa corresponde ao estágio em que a startup procura pelo produto e pelo modelo de negócio. Um estágio que finda com a validação do produto por parte do consumidor. A delimitação da zona cinzenta pode ser assim representada:

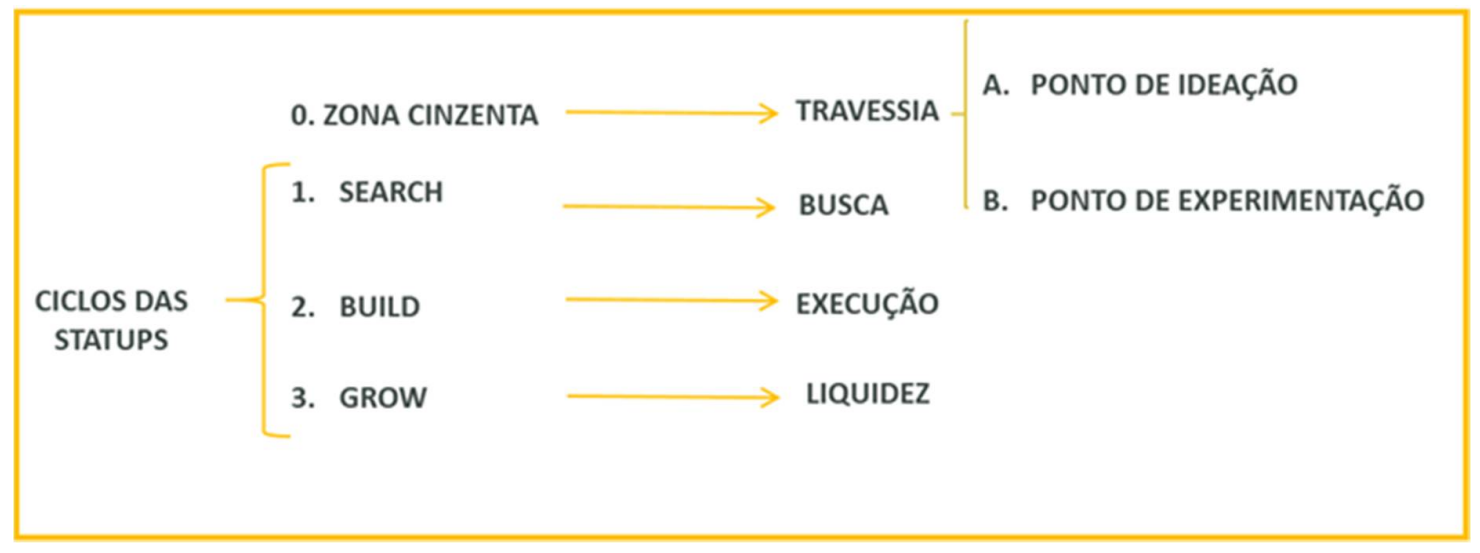

FIGURA 26. DELIMITAÇÃO DA ZONA CINZENTA ${ }^{85}$

A zona cinzenta, o transcurso entre a ideia e a execução apresenta dois momentos: ponto de ideação e ponto de experimentação, momento em que se estabelece um estreito diálogo com o ciclo das startups projetado por Steve Blank.

${ }^{85}$ Elaborado pela autora 
Como ocorrem os ciclos de incertezas e de criticidade para ações de projeção na zona cinzenta? Esta questão precisa ser respondida para que tenhamos uma televisão das ações dos novos idealistas nas suas praxeologias criativas. As teorias do caos e da complexidade podem explicar essa fase por meio dos desdobramentos que uma pequena ação produz sobre uma situação, tecendo redes de acontecimentos e realizações. Com efeito, os conceitos do universo caótico e complexo nos parecem úteis no esforço para produzirmos um exercício de reflexão quanto à criticidade enfrentada pelos novos idealistas, essencialmente na fase embrionária de criação de suas startups.

A imagem do efeito borboleta - utilizado pelos teóricos para articular os conceitos da teoria do caos - capta a essência dos sistemas das startups: uma alta sensibilidade às condições iniciais. Quais são as “condições iniciais”? A ideia! Mais que a ideia: a ideação, objeto do capítulo seguinte: uma "eureca" que ocorre como atrator para sua montagem. Seus fenômenos "simples" são de grande caoticidade. No entanto, observamos que existe uma ordem caótica nos seus fenômenos imprevisíveis de realização.

A teoria do caos nos mostra que uma pequena ideia pode provocar uma grande mudança. A ideia de Tallis Gomes de usar geolocalização dos smartphones para acionar taxis provocou profundas mudanças nos serviços pagos de mobilidade individual de passageiros. Cada celular hoje pode ser transformado em um "ponto" de taxi. Com efeito, Gleiser (2002, p.23) define a teoria como o estudo de "comportamentos instáveis e aperiódicos em sistemas dinâmicos determinísticos-não lineares" como de fato ocorre com os fenômenos das startups em seu estágio embrionário.

Entretanto, a existência de padrões e leis não implica em possibilidade de previsão, uma vez que uma alteração mínima nas condições iniciais pode provocar mudanças profundas de comportamento ou trajetória desses sistemas complexos (GLEICK, 1989, GLEISER, 2002). Na zona cinzenta, a previsibilidade - se é que podemos afirmar sua existência - ocorre em um grau de grande incerteza. Na sua travessia, os novos idealistas avançam em meio às incertezas, escavando em busca de descobertas e experimentando caminhos, tecendo novas criações. Nessa empreitada, as lições tradicionais de criação de empresas ${ }^{86}$, com seus instrumentos presumíveis e seus modelos lineares de demarcação e planejamento passo a passo centrados em estratégias, oferecem comprometedoras limitações.

Os idealistas, na difícil tarefa de avançar sem uma clareza do que será encontrado no passo adiante, encontram em suas próprias ações presentes, os insumos para potencializar os

${ }^{86}$ No Capítulo 3 - Caracterização das startups, abordamos a metodologia de criação de empresas na perspectiva do 'desenvolvimento de produto' e na perspectiva do 'desenvolvimento de clientes'. 
chances de sucesso, reduzir as incertezas e minimizar os riscos no passo seguinte. Eles sabem que precisam experienciar a desordem com resiliência e persistência, sempre abertos ao acontecimento e à autoaprendizagem. As suas projeções e criações estão baseadas na utilização de suas experiências precedentes e as adquiridas na própria travessia e não na obediência de processos engessados e predeterminados de criação.

Com efeito, no early stage (estágio inicial, embrionário), os idealistas experimentam o estado de desequilíbrio, sendo este um importante elemento de produção do conhecimento acerca dos elementos que compõem as suas ideias e da criação da inovação. Os idealistas não estão interessados em explorar o já existente, mas sim criar novos mercados ou promover mudanças naqueles já existentes. Eles estão impulsionados a participar de uma revolução e para isso estão dispostos a produzir ações em uma zona de desconforto. Cooperar, compartilhar, desterritorializar, prototipar ideias, coletar e tratar dados, realizar testes, ajustes e (re)criar. Os idealistas agem no caos e por meio de ações rizomáticas, experienciando um estado de desequilíbrio e de relações de interdependências.

Tomada como uma emergência da complexidade, a produção das startups em seu early stage é um fenômeno caótico. As startups essencialmente em seu estágio inicial ocorrem de forma instável e imprevisível, produzindo um tecimento com base na indução, nas experienciações e nas redes de afetos que passam a ocorrer em torno da produção da sua existência - o que, de fato, caracteriza uma rede de alta complexidade.

O que é a complexidade? Morin responde esta questão em seu livro Introdução ao pensamento complexo (2007, p. 13):

A um primeiro olhar, a complexidade é um tecido (complexus: o que é tecido junto) de constituintes heterogêneas inseparavelmente associadas: ela coloca o paradoxo do uno e do múltiplo. Num segundo momento, a complexidade é efetivamente o tecido de acontecimentos, ações, interações, retroações, determinações, acasos que constituem nosso mundo fenomênico. Mas então a complexidade se apresenta com os traços inquietantes do emaranhado, do inextrincável, da desordem, da ambiguidade, da incerteza...

O pensamento complexo é contemporâneo de um período de intensa atenção à necessidade de pensar um tipo de conhecimento científico que não reduzisse a complexidade à simplicidade. Não se trata de elegermos um corpus de startup. De selecionarmos uma representação e expor uma universalidade da coisa a partir daquele recorte. O que emerge na análise é a rede, é o tecido, é o próprio tecimento.

O pensamento complexo não se confunde com o pensamento do contexto buscando situar um fato, fenômeno ou um processo, mas sim de buscar conexões, relações, contradições 
que formam o social, que é visto com estruturas mutantes, imprevisíveis, em suas "vias" no caos e na multiplicidade, misturas de ordem, desordem, e se contrapõe ao pensamento reducionista, linear e simplificador. Para Morin (2007, p. 52):

[...] a complexidade não compreende apenas quantidades de unidades e interações que desafiam as nossas possibilidades de cálculo; compreendem também incertezas, indeterminações, fenômenos aleatórios. A complexidade num certo sentido tem sempre contato com o acaso. Assim, a complexidade coincide com parte de incerteza, quer mantendo-se nos limites do nosso entendimento quer inscrita nos fenômenos. Mas a complexidade não se reduz à incerteza, é a incerteza no seio de sistemas ricamente organizados. Ela relaciona sistemas semialeatórios cuja ordem é inseparável dos acasos que lhes dizem respeito. A complexidade está, portanto, ligada à certa mistura de ordem e desordem, mistura íntima, ao contrário da ordem/desordem estática, onde a ordem (pobre e estática) reina ao nível das grandes populações e a desordem (pobre, porque é pura indeterminação) reina [no nível] das unidades elementares.

Nos exemplos a seguir, relatamos essa "mistura" - as "incertezas" a partir de experiências dos novos idealistas na zona cinzenta. Seus relatos expressam, digamos assim, em estado bruto, as conceitualizações que realizamos para abordar os estágios da ideação e experimentação que compõem a zona cinzenta. Os autores expressam a revolução silenciosa que ocorre nas entranhas do capital por meio de novas formas de produção da vida e do trabalho.

\subsection{INÍCIO E TRAÇÃO}

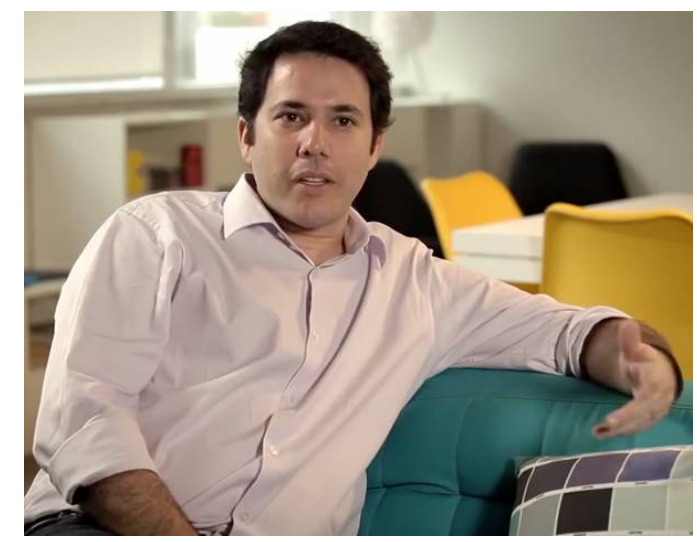

FigURA 27. PORTAL MINHA VIDA ${ }^{87}$

O portal 'Dieta e Saúde' e mais tarde o portal 'Minha Vida' organiza e democratiza conhecimento de saúde e bem estar de maneira fácil e acessível a todos.

${ }^{87}$ Episódio da série "Vai que dá: A cara das startups brasileiras", uma produção da Endeavor Brasil. Disponível emhttps://endeavor.org.br/vai-que-da-o-maior-portal-de-saude-e-bem-estar-brasil-minha-vida/. Acesso em 13 jun. 2016. 
O novo idealista Daniel Wjuniski, fundador do maior portal de saúde e bem estar do Brasil, expõe sua travessia na zona cinzenta ao relatar a experiência vivida na criação da startup

Minha Vida e aponta a fase inicial como sendo o momento de maior dificuldade na concepção do negócio, e uma fase de alto grau de incerteza:

Acho que o momento mais difícil é o começo mesmo. Até você entender que o seu produto tem tração. Você começa o negócio. Você investe seu tempo. Você investe seu dinheiro e de alguma forma você acredita, mas a maioria das pessoas que você conversa não acredita. E, por mais que todo empreendedor fala que nunca deixou de acreditar em um sonho, não existe nenhum empreendedor que foi deitar na cama e perguntou: será que isso é verdade mesmo? Será que eu não sou louco? (Informação verbal) ${ }^{88}$

Revolução: pegando carona no rabo do cometa:

Eu nasci em São Paulo e fiz Direito e Administração de Empresas. Quando eu estava no quarto ano das duas faculdades eu tranquei direito e comecei a trabalhar na Johnson \& Johnson. No meio desse estágio na Johnson, estourou a bolha da Internet e eu acabei saindo da Johnson para ir para a Webmotors. Eu lembro que uma das frases que me convenceram foi o Max me falando: "você não quer pegar carona no rabo desse cometa? Está acontecendo uma revolução. Você não quer fazer parte disso?" E eu queria fazer parte de uma revolução! (Informação verbal) ${ }^{89}$

Afetações: mais que uma oportunidade de negócio, uma razão para empreender:

Eu fui diagnosticado com uma doença crônica que chama Doença de Crohn. Eu nunca tinha ouvido falar nesta doença e a primeira coisa que eu fiz foi, trabalhando com a Internet, ir para Internet. Eu lembro que eu pesquisei e não encontrei nenhuma informação em português. Então eu vi que ali existia um gap, uma oportunidade de negócio, mais do que isso existia um grande propósito para que eu empreendesse. (Informação verbal) ${ }^{90}$

Aprendizado: avançando por meio de descobertas:

Em 2004, o mercado estava ainda muito retraído. Naquela época, o negócio de conteúdo como imaginávamos não era sustentável. E percebemos que a coisa de perda de peso era algo bastante relevante e onde existia um produto para a gente vender para o usuário final. A gente começou o negócio com 'Dieta e Saúde' que é a nossa marca até hoje para o nosso produto de emagrecimento. Em 2006 tivemos a ideia de lançar o 'Minha Vida', que era a nossa ideia inicial para democratizar a informação de saúde e bem estar mesmo. Acho que, para um negócio como o 'Minha Vida', teve como relevância para o usuário uma tração muito rápida. A gente entendeu e a audiência cresceu de uma forma meteórica. O reconhecimento da marca pelo internauta aconteceu de uma forma muito grande. (Informação verbal) ${ }^{91}$

${ }^{88}$ Idem

${ }^{89}$ Idem

${ }^{90}$ Idem

91 Idem 
Risco: saindo da zona de conforto:

O negócio foi lucrativo desde o segundo ano. Poderia remunerar bem o sócio desde o terceiro ano. Mas nunca foi isso que a gente quis. A gente sempre se incomodou em fazer alguma coisa grande. Nunca gostamos da zona de conforto. (...) entender o tamanho desse sonho e ir atrás é o meu trabalho diário. É o tempo inteiro entender onde está esse sonho grande. Olhar o sonho que já é grande e transformar em algo ainda maior. (informação verbal) ${ }^{92}$

\subsection{MUDANÇA E PARAGENS}

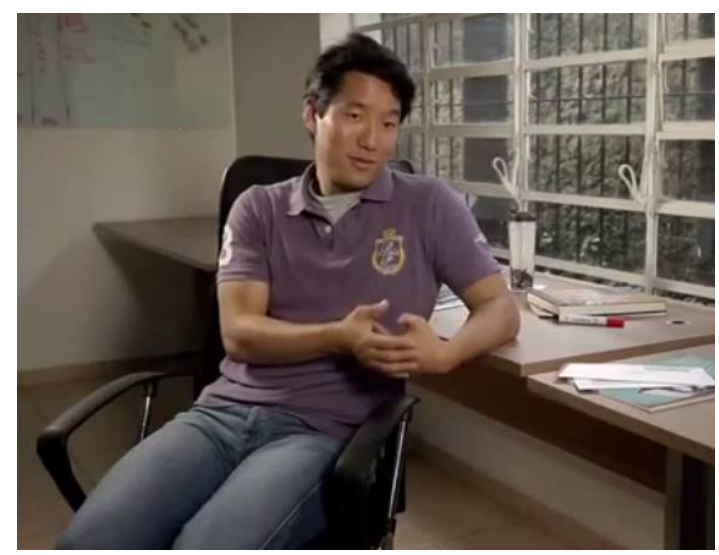

Figura 28. PLATAFORMA DE INTELIGÊNCIA KEKANTO

A Kekanto é uma plataforma que reúne avaliações, opiniões e dicas de usuários a respeito de milhares de estabelecimentos, organizando a cidade em um só lugar através de uma inteligência coletiva ${ }^{93}$.

Legado: criando algo novo, mudando maneiras de viver e fazer as coisas:

Em relação à vida, eu tento sempre pensar o dia em que eu estiver lá no finalzinho. Eu quero olhar para trás e ser um banqueiro de investimento, um consultor a minha vida inteira ou eu quero ter construído alguma coisa diferente que mudou a maneira como as pessoas vivem e que deixou um outro tipo de legado? (informação verbal) ${ }^{94}$

Paragens: vindo de outras paragens, sem buscar se fixar em um só território:

Eu sou paulistano. Com 17 anos eu prestei vestibular e entrei na faculdade de medicina da Universidade de São Paulo, cursei um ano e vi que não era muito o que eu queria fazer da vida. Então eu mudei para os Estados Unidos, ai eu

92 Idem

${ }^{93}$ Episódio da série "Vai que dá: A cara das startups brasileiras", uma produção da Endeavor Brasil. Disponível em https://endeavor.org.br/vai-que-da-kekanto/. Acesso em 09 jul. 2016.

${ }^{94}$ Idem 
formei em economia na Wharton School. Depois fui trabalhar em banco de investimento em Nova Iorque. Resolvi fazer o mestrado em Stanford e mudei para Sydney para trabalhar em uma consultoria. Quando eu voltei para o Brasil comecei a empreender. Saí de onde muitos consideram 'indústria dos sonhos' de pessoas que optam por uma carreira executiva como banco de investimentos ou consultoria estratégica, para criar alguma coisa que mude a vida das pessoas. (informação verbal) ${ }^{95}$

Inovação: rompendo ciclos de criação:

(...) ninguém aqui está trabalhando no governo ou numa multinacional enorme, porque a gente quer criar algo novo (...). Você tem que se sentir como se estivesse em cima de uma bicicleta e indo ladeira abaixo, pelo menos na grande maioria das ocasiões. Se você está sempre sentindo que você está empurrando a bicicleta ladeira acima alguma coisa está errado. (informação verbal $)^{96}$

\subsection{ABISMO E DESCOBERTA}

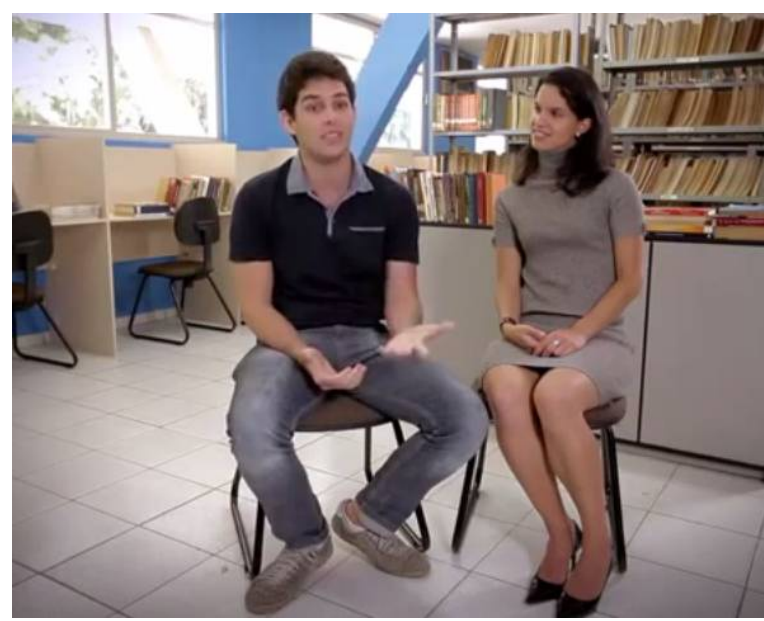

FIGURA 29. EDTECH QMAGICO

O Qmágico é uma plataforma de educação facilitada por uma tecnologia aplicada à eficiência do aprendizado, que leva a análise de dados, o uso da inteligência artificial e da intervenção pedagógica mais eficiente para o dia a dia em sala de aula. ${ }^{97}$

95 Idem

${ }^{96}$ Idem

${ }^{97}$ Episódio da série "Vai que dá: A cara das startups brasileiras", uma produção da Endeavor Brasil. Disponível em https://endeavor.org.br/vai-que-da-transformando-educacao-com-tecnologia-qmagico/ Acesso em 09 Jul. 2016 
Criando do zero: conectando pessoas, ideias e conhecimento:

Eu acho que o desafio de empreender é a arte de fazer aquilo que você mais gosta sem ter nada. Está dentro de um mundo que você não conhece e dá um jeito de tirar as coisas do chão e ser muito feliz com tudo aquilo. É justamente você partir de um ponto inicial que é uma ideia, atrair pessoas, fazer estas pessoas acreditarem neste sonho junto com você e querer te ajudar na sua caminhada. (informação verbal) ${ }^{98}$

Problematização: deparando-se com um problema que afeta e mobiliza:

Eu comecei a trabalhar em uma ONG de educação que envolve vários alunos do ITA, Unicamp, USP. Eu me envolvi na parte administrativa e depois virei diretor de recursos humanos e depois presidente. E, nesse caminho, eu fiquei me questionando como é que eu fazia para criar uma coisa que fosse sustentável - não dependesse de doação - e escalável, ou seja, não dependesse tanto de espaço físico e que eu pudesse replicar o modelo para o Brasil inteiro. (informação verbal) $^{99}$

Descobertas: Ações pautadas em um 'saber vivo' que emerge das próprias práticas:

Parece que passamos nove meses de desenvolvimento e criação do produto fazendo uma coisa que não fazia nenhum sentido. A gente ficou trabalhando um ano se sustentando com recursos próprios e investindo só na empresa para consegui ter o 'a-há!' de como a gente vai monetizar e cumprir a nossa missão. (Informação verbal) ${ }^{100}$

Abismo: agarrando-se a uma ideia:

Ideias não são das pessoas, ideias são do mundo. Todas as pessoas estão em uma caminhada, subindo a montanha e enxergando várias ideias. São poucas aquelas que têm a coragem de pular e se agarrar naquilo pelo qual é mais apaixonado e cair naquele abismo. E depois que você percebe que você pode fazer isso ou que você tem a coragem de pular... Na minha vida, isso foi talvez o momento mais importante. Acreditar que essas coisas eram possíveis! (Informação verbal) $^{101}$

${ }^{98}$ Idem

${ }^{99}$ Idem

${ }^{100}$ Idem

101 Idem 


\section{PONTO DE IDEAÇÃO}

- De repente, um idealista se apaixona por uma ideia. Digo "de repente", mas de fato é algo que passou a acontecer no seu pensamento em claros-escuros - não assim tão imediato. Como um desejo de viajar, ou fazer algo novo, ou reeditar um percurso. Normalmente esse desejo é uma contracorrente produzida por uma afetação apaixonante. E logo envolve outros. Não é uma correnteza contra tudo e todos - uma ruptura avassaladora. Não. É uma contracorrente, porque demarca um percurso novo. Assim como, por exemplo, uma nova forma de escrever e editar um livro ou uma nova forma de produzir uma dissertação de mestrado. Como fazê-lo? Estas formas vão se estruturando em uma relação entre pensamento e contexto, pessoas e coisas. O como é o que atina e desatina. Daí decorre a ideação: um desejo que se ramifica e se estende em encontros em busca de uma conceitualização.

No ponto de ideação ocorrem as ações da Zona Cinzenta no sentido de uma previsão do produto a ser construído. Trata-se de uma praxeologia no entorno de uma criação. Parte-se de uma ideia central, ainda muito difusa para um esforço de conceitualização. A partir de lugares das convivências diárias, do cotidiano, os novos idealistas idealizam uma projeção, um produto, um afazer. Não estão presos a esses lugares, mas habitam neles, produzem relações a partir-de.

A concepção ocorre no primeiro estágio, como uma afetação interrelacionada a encontros. Algo muito concreto, no entanto, mobiliza o pensamento, acionando questões, problemas que se propagam no social em redes desejantes a produzir agenciamentos (DELEUZE; GUATARRI, 1997). Dessa relação entre afetação e encontros ocorre um processo de ligação conceitual, experienciação do pensamento e criação. Este capítulo discute justamente os processos que ocorrem nas startups entre problema-encontro e criação, no primeiro estágio da Zona Cinzenta.

\subsection{AFETAÇÃO}

Nos momentos aqui intitulados de "afetação", o problema que vai impulsionar o novo idealista é uma previsão para produção de uma representação. Algo que está ainda em um processo embrionário que ocorreu de outras relações. Está no plano de uma "crença", como algo que mobiliza e um desejo de produzir um "legado". O que mobiliza é uma ideia- 
contracorrente, uma "periferia" no fazer. A contracorrente não é necessariamente um confronto com o estabelecido. Mas, sem dúvidas, uma linha de ação sobre o que "está aî". Ao pensá-la, os novos idealistas produzem-se. No plano teórico, é o que Gorz chama de "produzir-se", onde a pessoa torna-se empresa, um auto-empreendedor, sendo ela sua própria produtora: "Cada um deverá gerir seu capital humano ao longo de sua vida" (GORZ, 2005, p. 24).

Nesse momento, algo que mobiliza é o legado e o fazer-se. Os novos idealistas deparamse com um problema que os afeta, com o questionamento, causando intenções e desejos que os impulsionam. Aqui o vocábulo afetar nos remete às noções de modificar, transformar, alterar. Noções que nos permitem perseguir elementos conceituais da filosofia de Spinoza. No livro III da obra "Ética" (2016), o filósofo trata da origem e da natureza dos afetos humanos. "Por afeto compreendo as afecções do corpo, pelas quais sua potência de agir é aumentada ou diminuída, estimulada ou refreada, e, ao mesmo tempo, as ideias dessas afecções. (SPINOZA, 2016, p. 98). Nessa definição, as afecções são as modificações sofridas pelos corpos nos encontros com outros corpos. Já o termo "ideia” nesta definição é compreendida como um conceito da mente como coisa pensante, ou seja, é um modo de pensamento que representa alguma coisa, e não percepção. Isso porque "a palavra percepção parece indicar que a mente é passiva relativamente ao objeto, enquanto conceito parece exprimir uma ação da mente", justifica Spinoza (Ibidem, p. 51).

Ao postular que o corpo humano pode ser afetado de muitas maneiras, pelas quais sua potência de agir, bem como a potência de pensar da mente, são constrangidas ou favorecidas. Spinoza (2016, p. 99 - 106) nos revela que existe uma coisa que nos é essencial, por ele chamada de potência de agir. Trata-se de uma energia em contínua variação, transformada pelos afetos sucessivos, que demarcam passagens da mente de um menor grau de perfeição a um maior grau de perfeição. Esses polos de variação da potência de agir envolvem os encontros, ou seja, a maneira dos corpos serem afetados por outros corpos. Quando estes encontros produzem a ideia de um efeito que compromete ou destrói nossa própria relação, acabam por destruir ou diminuir este esforço, ou seja, a potência de agir. Em contrapartida, quando esses encontros produzem uma ideia de um efeito que se concilia ou favorece nossa própria relação característica, acabam por produzir um aumento da força de potência, realizando uma passagem para um corpo mais potente para viver e realiza. Há um favorecimento da potência de agir, onde as potências da mente e do corpo são alavancadas. Assim, os afetos são experiências vividas, transições, passagens.

Com efeito, no ponto de ideação, algo mobiliza os idealistas e os afeta, tanto com base nas relações imediatas, como em outras relações que se estabelecem em suas vidas - ao mesmo 
tempo nômades e sedentárias (DI FELICE, 2009). Como podemos perceber na declaração de Abussamra (2016) sobre a decisão de criar uma startup, ele estava infeliz, "preso" a uma empresa como gerente de desenvolvimento. O que lhe impulsionou à mudança foi um amigo que desejava "deixar um legado".

Até fevereiro/março de 2015, eu estava trabalhando em uma empresa como gerente de desenvolvimento. Eu estava muito infeliz lá. Mas muito mesmo! Em paralelo a isso, o Omar, o meu sócio, um executivo de sucesso, queria deixar um legado. Ele não tinha ainda criado nada em si e estava com o desejo de criar alguma coisa nova. Nós somos amigos de infância. (informação verbal) ${ }^{102}$

"Deixar um legado" passou a ser um dispositivo de criação, mudança, desterritorialização de espaços previsíveis. "Ser feliz" é também um motor da ação. Esse mundo novo de um desejo de redenção está muito associado a romper com o mesmo. A "ditadura" do mesmo. Decolar do "chão" está associado, neste caso, a uma projeção com alguém que também deseja "deixar um legado". O amigo acionou outro amigo, acionado que estava por uma rede de realizações. Assim ocorrem os processos de afetação.

Antes de retomar o contato comigo, ele foi ao Vale do Silício, participou de eventos e voltou com a ideia fixa de empreender. Então me procurou e trouxe ideias bacanas e eu levei também ideias para ele, motivado também pelo momento em que eu vivia de um trabalho muito chato que eu estava vivendo e, no final, eu acabei sendo desligado pela empresa. Ai eu pensei agora é full time nisso. (informação verbal) ${ }^{103}$

Movidos por desejos de deixar legado, desterritorializar-se, criar, os idealistas identificam, através de suas experiências e vivências, as oportunidades de negócios. O desejo não atua como uma falta, mas como um apetite consciente (SPINOZA, 2016), como a produção de novos arranjos, construção de agenciamentos, conjuntos (DELEUZE; GUATTARI, 2010). Com efeito, os encontros, as experiências pessoais e profissionais funcionam com uma força que impulsionam as suas ideias. O desejo de empreender parece ser algo que vem de longe. No entanto, a ação prática está circunstanciada por formações específicas. A especificidade da criação também ocorre a partir de problemas das vivências.

Desde a faculdade eu já tinha o interesse em empreender. Então eu lia livros, dava aulas particulares... Já quis montar um cursinho com os amigos para dar aula particular e participei de jogos de empreendedorismo como desafio Sebrae. Aí a oportunidade veio depois

102 Entrevista concedida por João Abussamra, co-fundador da startup Wairon, plataforma colaborativa para serviços de passagem e lavagem de roupas. Entrevista V [jan. 2016]. Entrevistadora: Ana Patrícia Santana. A entrevista na íntegra encontra-se transcrita no Apêndice E desta monografia.

103 Idem 
de três anos de formado e eu abri minha própria empresa. (...) Como eu estudei engenharia da computação e também tenho um background, eu sempre gostei de ficar analisando modelos de negócio. Nessa época trabalhava com consultoria, então sempre gostava de ficar mexendo nestas coisas. Eu vi que em 2010-2011 tinha aquela febre de compras coletivas e vários e-commerce de nichos. A internet bombando e todo mundo fazendo plataforma para esse fim, mas não tinha nada para serviços. Eu lembro que na época eu precisava contratar um pintor lá pra casa e na época foi uma confusão contratar. Aí eu pensei: acho que tem um mercado aqui. E comecei a pesquisar o que estava sendo feito lá fora e vi que a solução para o Brasil teria que ser diferente. Então eu decidi criar minha própria solução e fundar o GetNinjas. (informação verbal) ${ }^{104}$

É a partir dos problemas identificados que os afetam que os novos idealistas criam os conceitos (modelagens e produtos) de suas startups. São os problemas que mobilizam a produção conceitual de suas soluções high-tech a partir de análise em aberto de modelos de negócios. Trata-se de encontrar nichos. Eis a garimpagem. E, em seguida, montar estruturas fluidas. Estas estruturas se entrelaçam com as estruturas molares da grande economia. Em determinados lugares, essas estruturas vão de encontro ao molar, em outros, simplesmente se inter-relacionam.

Ao perceber o ato de criação, Deleuze (1998 apud GALLO, 2013) ${ }^{105}$ assinala que criar significa ter uma ideia, e que todo criador age por necessidade e não por impulso. É a vivência sensível de um problema que leva o criador à criação, a ter de fato algo a dizer aos outros. Os novos idealistas, sejam estes qualificados com background tecnológico e em business ou outsiders, abraçam com foco e resiliência o desafio de construir condições em torno da sua ideia para viabilizá-la - como nos afirma Samir Iásbeck, cofundador da startup Qranio, um aplicativo de games para treinamentos:

Eu não sabia nada desse negócio de startup. Isso para mim era tudo novidade. Eu sempre fui muito empreendedor desde pequeno, mas muito voltado para área comercial e vendas. (...) Eu nunca fui uma criança que gostava de estudar. Para mim, ir para a escola não fazia sentido algum, mas eu gostava de

${ }^{104}$ Entrevista de Eduardo L'Hotellier, fundador e CEO do GetNinjas para o Canal Sebrae-SP, uma instituição sem fins lucrativos, coordenada por representantes da iniciativa privada e do setor público, e que tem por objetivo estimular e promover o desenvolvimento do empreendedorismo e das empresas de micro e pequeno porte no Estado de São Paulo. Disponível em: https://www.youtube.com/watch?v=VTj5kB1lV1Y. Acesso em: 20 jun. 2016.

${ }^{105}$ Em nota de rodapé, Silvio Gallo (2013 p.55) nos informa que o material referenciado corresponde à conferência proferida na Fundação Europeia para os Trabalhos com Imagem e Som (Femis) em 17 de março de 1987. Intitulada de "Qu'est-ce que l'acte de création?", tradução "O que é o ato de criação?", está disponível em formato digital na edição em DVD do documentário de Pierre-André Boutang e Claire Parnet, "L'abécédaire de Gilles Deleuze". Em 1998 foi publicada a transcrição completa na revista Trafic, n.27. O texto foi publicado no segundo volume da edição de textos e entrevistas organizado por David Lapoujade, Deux régimes de fous, até o momento sem tradução no Brasil 
aprender. Quando eu estava no último ano da faculdade, eu tinha uma software house e eu via minha filha, hoje com quatro anos de idade, com as mesmas questões que a minha. Ela prefere brincar do que ir para a escola estudar. Ai eu pensei. Puxa! Vou tentar criar uma forma de tornar o aprendizado divertido, mas não uma ferramenta para dentro de sala de aula, ou para substituir o professor. (...) A ideia do Qranio eu fiquei maturando durante muito tempo. Me perguntam quando surgiu o Qranio? O Qranio surgiu em 1981, quando eu nasci, porque estava dentro de mim e eu só não sabia ainda. (informação verbal) $)^{106}$

Inicialmente, as ideias surgem por meio de identificação de oportunidade a partir de um problema que emerge exigindo solução prática, imediata, rotineira. A partir daí, os novos idealistas vão cavando, pesquisando e realizando um esforço para entender mais do seu mercado e das oportunidades em torno desta ideia. À medida que os elos evoluem nesse caminho de descobertas, os novos idealistas avançam para modelos de negócios e produtos mais inovadores, que transcendem o caráter funcional e de resolução de problemas, incialmente pensados. Diferente das startups nascidas no Vale do Silício e na Europa, que já surgem com ideias mais globais, as startups brasileiras geralmente são criadas a partir de ideias mais particulares e desenvolvem estruturas de negócios voltadas para o mercado local.

Nesse ponto de ideação, as experiências pessoais são mescladas com a percepção de mercado na idealização de uma projeção do produto a ser construído. Os novos idealistas buscam descobrir quão relevante é a sua ideia, se ela afeta também outras pessoas e como ela pode resolver o problema identificado. O criador do Easy Taxi relata que a criação da aplicação para chamada de táxi surgiu de uma experiência particular de dificuldade de pegar táxi na cidade do Rio de Janeiro, somada a seu desejo de deixar um legado através da oferta de uma solução para o problema de trânsito na cidade.

A grande verdade é que idealista que sou eu sempre quis fazer alguma coisa que impactasse a vida das pessoas. Meu drive de fato nunca foi dinheiro. Eu queria fazer alguma coisa que de fato impactasse a vida das pessoas e de fato deixe algum registro, deixe algum legado. Eu achei que resolver o problema do trânsito, mesmo que parcialmente, era algo que deixaria um legado para o mundo. Foi quando eu cheguei em um concurso de startup em junho de 2011 no Rio de Janeiro com a ideia de um aplicativo para pegar ônibus e acabei adaptando esta ideia para taxi, a partir de uma necessidade minha. Foi daí que criei a Easy Taxi (...). No final de contas é isso que é o empreendedorismo, você resolve problemas com troca de dinheiro. (informação verbal) ${ }^{107}$

106 Entrevista concedida por Samir Iásbeck, cofundador da startup Qranio para o videocast sobre empreendedorismo e cultura digital. Entrevistadores: Leo Cuba e Miguel Cavalcante. Disponível em: বhttps://www.youtube.com/watch?v=wcBNz24T6Hk> Acesso em 03 abr. 2016.

${ }^{107}$ Entrevista de Tallis Gomes, fundador e CEO do Easy Taxi para o Canal Sebrae-SP, uma instituição sem fins lucrativos, coordenada por representantes da iniciativa privada e do setor público, e que tem por objetivo estimular 


\subsection{ENCONTROS}

Os encontros dos novos idealistas ocorrem sempre em uma promoção permanente, de forma espontânea ou programada. O encontro não é seletivo. Não é necessário estar em um ponto tal de maturidade da ideia. São encontros promovidos comumente pelos agentes do próprio ecossistema de startups e reúnem idealistas nos mais diferentes níveis de maturação do empreendimento. Sempre promovem a informalidade para compartilhamento de previsões. É um momento em que os novos idealistas encontram competências complementares. Um idealista da área comercial, por exemplo, consegue encontrar um programador para avançar com a sua ideia.

Atento à relação que um corpo estabelece com o ambiente ao seu redor, o conceito spinoziano de encontro está diretamente relacionado ao conceito de afeto, ou seja, quando os corpos se encontram produzem afetos. Para Spinoza, os bons-encontros são aqueles que aumentam a nossa capacidade de agir e estabelecem as conexões necessárias para pensar o que convém e o que não convém. São pelos bons encontros que formamos noções comuns, que são o conhecimento das relações necessárias da parte (no caso, nossa singularidade) com o todo (no caso, o ambiente). Com efeito, "quanto mais uma coisa concorda com a nossa natureza, tanto mais útil ou melhor é para nós; e, inversamente, quanto mais uma coisa nos é útil, tanto mais concorda com a nossa natureza." (SPINOZA, 2016, p. 175).

Nos encontros, os novos idealistas partem em busca das redes desejantes que estão em seus focos. Redes de pessoas que poderão também estar afetadas por motivações similares às suas. Ao conviver com essas redes de desejos, os novos idealistas falam do legado, do que mobiliza, dos problemas identificados, dos questionamentos, e possivelmente produzem préagenciamentos, relações, motivações. Com efeito, Deleuze (2010) afirma que o grande ser da criação são os encontros. São neles que se fazem novas redes e conexões de saberes. Nesses encontros é que nos conhecemos, projetamos, produzimos nossas redes de desejos. Fazemos encontros porque há em nós a convergência de certo número de singularidades - uma particularidade não particular, porque não é ser de um ser só.

Quando nos propomos a analisar as startups em um ponto de ideação, o fator humano torna-se um elemento fundamental. São comuns os casos de startups que iniciaram a partir de projetos entre pessoas do mesmo grupo de amizade, colegas de faculdade, de trabalho, encontros nas redes ou em eventos de fomento ao empreendedorismo. As histórias iniciais das 
startups em geral possuem relações intrínsecas com as experiências, com as histórias ou com os desejos dos seus fundadores. Nessa fase tudo é muito subjetivo e as ações estão estreitamente relacionadas com as vidas desses novos idealistas. É um movimento de desejos e múltiplas relações.

Em sua busca por conexões, os novos idealistas encontram no meetup uma excelente oportunidade de discutir as suas ideias. Oriundo do Vale do Silício, o meetup é um encontro informal, como um happy-hour, que facilita a circulação de pessoas e a construção de networking qualificado em um ambiente de descontração. Nesses meetups, os empreendedores produzem redes e interagem com pessoas que podem contribuir para fazer sua ideia avançar. Neles é possível encontrar sócios, desenvolvedores, designers, prestadores de serviços, mídia, entusiastas de tecnologia, investidores e empreendedores experientes.

Organizado pelo ecossistema de startups e por comunidades locais, os meetups são eventos regulares e muito frequentados por esses novos idealistas. A intenção é que as pessoas circulem livremente e se conectem. Para auxiliar no cumprimento desse objetivo, os participantes são identificados com nome e interesse. Geralmente existem alguns voluntários facilitadores que auxiliam os participantes a fazer contato e encontrar as pessoas certas. Esses eventos podem sofrer algumas adaptações em seu formato, reservando espaços e momentos do encontro para sessão de Mentoring, que conecta startups a especialistas e empreendedores experientes, ou sessão de bate-papo sobre negócios e tecnologia com convidados, sempre tendo como intenção promover o diálogo de pessoas interessadas em empreendedorismo, tecnologia e inovação em espaços informais. Assim, as fronteiras entre business e a vida são diluídas, dando espaço a um saber produzido em sincronia com o outro, onde esses novos idealistas se autoproduzem à medida que tecem suas ideias em conexão.

Uma outra iniciativa nessa direção é o Beer or Coffee, aplicativo que permite convidar pessoas disponíveis próximas a você para um café ou cerveja objetivando criar laços e trocar experiências com pessoas que compartilham do mesmo interesse, criar oportunidades e cooperação. O aplicativo tem uma parceria com o Silicon Drinkabout, encontro semanal que ocorre às sextas-feiras e reúne pessoas interessadas em startup, tecnologia, inovação e empreendedorismo. Criado em Londres, o meetup hoje já está presente em 18 cidades ao redor do mundo e ajuda os empreendedores na construção de networking qualificado ligado à cena local do ecossistema, a obter feedback amigo e a conectar-se com a comunidade de startups. 

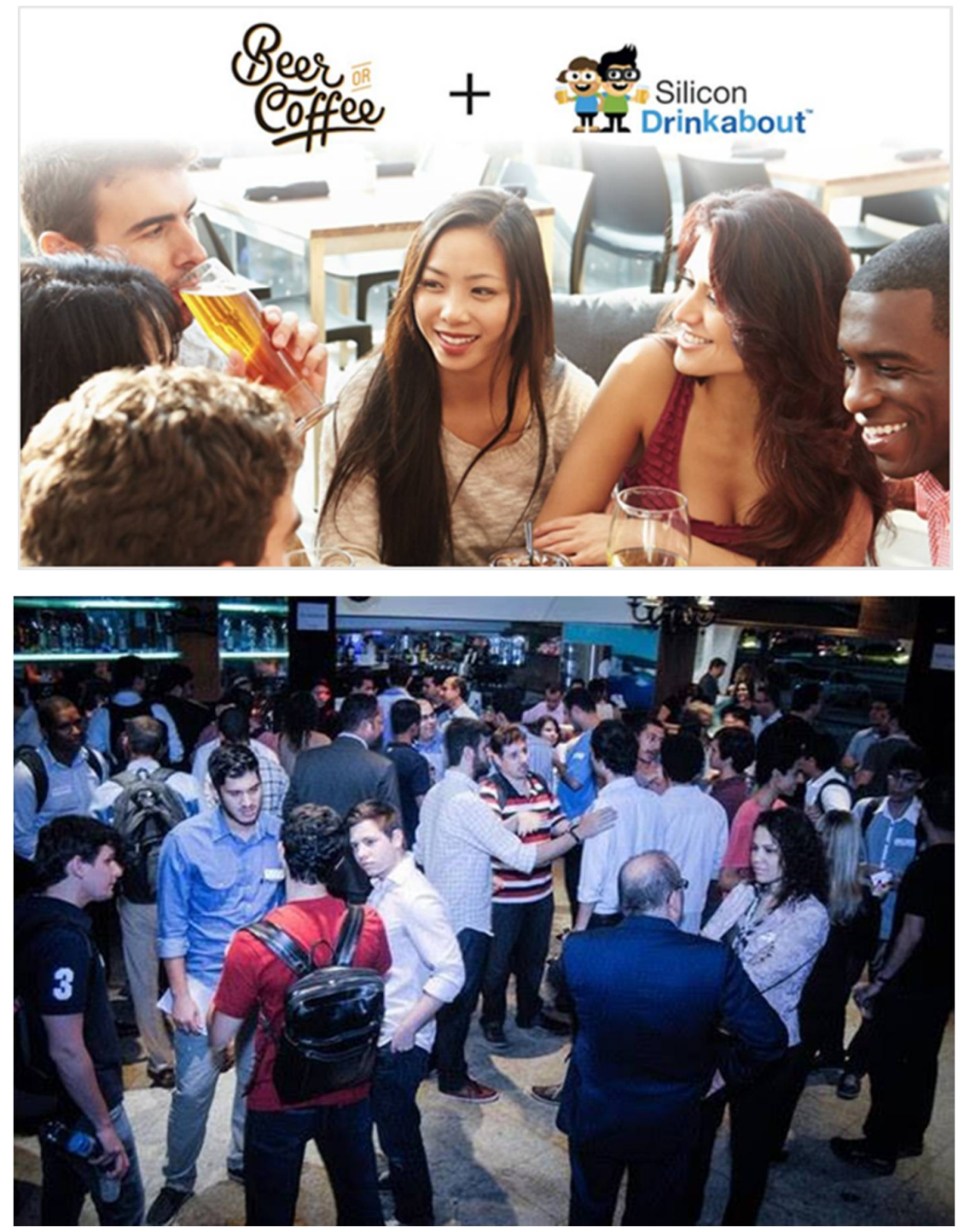

\section{FIGURA 30. MEETUP COM TECNOLOGIA E EMPREENDEDORISMO}

Na primeira imagem, comunicação do app brasileiro Beer or Coffee em parceria com o Silicon Drinkabout, meetup/happy hour que reúne pessoas ligadas a tecnologia e startups. Na figura embaixo, o Meetup Startup, encontros regulares promovidos pelo circuito startup ${ }^{108} \mid$

O problema que impulsiona as startups na zona cinzenta vem da experiência, vem da própria ação. O problema é objetivo, portanto. Por esta razão, os problemas das startups agenciam as experiências. Quando Deleuze (2010) afirma que o problema ocorre pelos encontros e agenciamentos, ele está livrando o problema de um caráter subjetivo. Não se trata da construção de um sujeito - do tipo: qual a questão da sua startup? -, mas de uma rede que age para sua construção.

${ }^{108}$ Imagens disponíveis nos sites <http://note.taable.com/post/1D9D80/Circuito-Startup-Pho/2b-5-90-68-58099179-90-7909-4T35> e <http://3-beards.com/silicondrinkabout/saopaulo>. Acessos em 01 mai. 2016. 
O problema desempenha um papel central na produção do pensamento. Ou seja, o problema nos força a pensar. O problema é, por assim dizer, o motor da experiência. Como Tallis Gomes, fundador do Easy Taxi, aplicativo mobile para chamada de táxi, teria criado em menos de 24 horas o produto em um evento-competição se não tivesse identificado o problema de pegar táxi via cooperativa no estado do Rio de Janeiro? Como Eduardo L'Hotellier, fundador da startup GetNinjas, teria feito toda a movimentação para construir a plataforma de serviços sem ter vivido a dificuldade de contratar um pintor para sua casa? Como Samir teria se sensibilizado a criar o aplicativo Qranio, que utiliza de conceitos de gamificação para tornar o aprendizado mais divertido, sem a vivência do problema de motivação em seu próprio aprendizado e, mais tarde, no aprendizado de sua filha?

Nesse ponto de ideação, o idealizador toma a decisão por enfrentar o problema identificado, considerando o problema como o motor para o seu pensamento. Thiago Feijão, criador da startup Qmágico, plataforma de educação facilitada pela tecnologia, relata suas experiências de afetações e encontros:

Quando em tinha 12 anos de idade eu estava na sexta série, como se chamava antes, e eu tive a sorte ou a oportunidade de ter um professor de matemática que me convidou para fazer parte da tese de doutorado dele. Era uma tese que tratava de educação e cidadania. Ele me ensinou a enxergar as injustiças que estavam ao nosso redor e como a gente deveria contribuir para solucionar elas. Então quando eu entrei no ITA não demorou muito para eu procurar na região de São José dos Campos alguma coisa que eu pudesse contribuir com o que eu aprendi. Então, eu comecei tirando dúvidas de alunos de baixa renda numa Ong da região. Eu fui me envolvendo com a parte administrativa, quando eu pensei: se alguém fundou esta Ong isso significa que eu também posso fundar outras Ongs e fundei duas ongs. (informação verbal) ${ }^{109}$

Nesse caminho, ele ficou se questionando como poderia fazer para criar alguma coisa que não dependesse de doação (fosse sustentável), não dependesse tanto de espaço físico (fosse escalável) e que permitisse ter seu modelo de replicação para o país inteiro ${ }^{110}$. Foi com a participação das tecnologias digitais e com a cooperação de professores das ONGs em que estava envolvido que Feijão encontrou condições para colocar sua ideia em movimento.

\footnotetext{
${ }^{109}$ Fala de Thiago Feijão em conteúdo audiovisual produzido pela "Imagina Coletivo", organização sem fins lucrativos que trabalha para ativar o potencial de transformação das pessoas. A organização que trabalha com a comunicação e atua em mercado brasileiro, realiza projetos que objetivam promover narrativas em que todos são protagonistas na construção do mundo que imaginam. Disponível em: <https://www.youtube.com/watch?v=GrkI6STdIgc> Acesso em 30 jun. 2016.

${ }^{110}$ Episódio da série "Vai que dá: A cara das startups brasileiras", uma produção da Endeavor Brasil. Disponível em <https://endeavor.org.br/vai-que-da-transformando-educacao-com-tecnologia-qmagico/> Acesso em $09 \mathrm{Jul}$. 2016.
} 
O Qmágico surgiu desta ânsia. Como é que eu vou pegar os modelos destas ONGs e replicar para que todo o aluno e todo o professor tivesse aquele tipo de oportunidade? Assim, a gente construiu uma plataforma tecnológica que tem uma série de funcionalidades de inteligência artificial para que o professor possa usar isso como um novo giz e saber exatamente como cada aluno está (...). (informação verbal) ${ }^{111}$.

Pode parecer até despretensioso a afirmação que o Qmágico produz um novo giz, mas este signo tem um potencial de revelação do protagonismo com as tecnologias high tech. $\mathrm{O}$ novo giz nos diz que o que de fato ocorre não é rompimento, mas uma adequação. Isso de fato ocorre com outras startups e, mesmo revolucionando o modus operandi, interfere no percurso, mas não na realidade que produz sua reprodução.

No momento de ideação, o novo idealista realiza seus primeiros passos de aproximação e envolvimento com o ecossistema de startups, buscando caminhos para fazer brainstorming, trocar experiências, fazer networking qualificado e encontrar cofounders. Nessa fase, o empreendedor em potencial realiza um esforço individual para ampliar competências e conectar-se, buscando pessoas que possam ajudá-lo e capturando o "saber vivo" circulante nas redes de redes que compõem o ecossistema de startups. É das relações comunicativas, pessoais, interpessoais e de afetos que os empreendedores extraem os primeiros feedbacks, que oferecem contribuições significativas para suas ideias iniciais. "Conte sua ideia para o maior número de pessoas possível ${ }^{12} "$, recomenda Eduardo L'hotellier, ao relembrar que foi compartilhando com seus amigos a intenção de criar um marketplace, que recebeu como sugestão de um deles a possibilidade de comprar uma aplicação pré-pronta na Índia, ferramenta que o permitiu testar rapidamente o seu conceito com a plataforma "Cidade dos Bicos" e que viria a se tornar a maior plataforma de serviços brasileira, chamada GetNinjas.

\subsection{CONCEITUALIZAÇÃo}

A conceitualização se trata de equacionar o projeto, dizer seu movimento, ou seja, relacionar a ideia com o problema. Aqui, o problema é o motor da experiência de pensamento conceitual, o agenciador. $\mathrm{O}$ seu fazer antecipa a experimentação com conceitos e a

${ }^{111}$ Fala de Thiago Feijão em conteúdo audiovisual produzido pela "Imagina Coletivo", organização sem fins lucrativos que trabalha para ativar o potencial de transformação das pessoas. A organização que trabalha com a comunicação e atua em mercado brasileiro, realiza projetos que objetivam promover narrativas em que todos são protagonistas na construção do mundo que imaginam. Disponível em: 〈https://www.youtube.com/watch?v=GrkI6STdIgc > Acesso em 30 jun. 2016.

112 Fala extraída do material audiovisual 'Um minuto com Eduardo L'Hotellier'. Disponível em: <https://www.youtube.com/watch?v=nqy8BrHVqZU > Acesso em: 01 Jul. 2016. 
prototização. Expressa a ideia e sua forma para sustentação do conteúdo da solução da startup. A conceitualização vai definir a coisa que será quanto à modelagem e produto.

Ao tematizar sobre o pensamento na obra “Diferença e Repetição”, Deleuze (2006) não percebe o pensamento como algo natural. "Há no mundo alguma coisa que força a pensar. Este algo é objeto de um encontro fundamental e não de uma recognição.” (Ibidem, p. 203). Fruto do encontro, o problema parte do sensível, de uma experiência problemática vivenciada e sentida que mobiliza o pensamento enquanto experimentação do incômodo, do desconhecido, ou seja, daquilo ainda não pensado, no intento de construir o novo que nos permita enfrentar o problema que nos atinou a pensar.

Nesta direção, a experimentação do problema somada à mobilização do pensamento, produz conceitualizações. Para Deleuze e Guatarri, todo conceito é uma multiplicidade e diz o acontecimento, e não a essência das coisas, definindo-se pela inseparabilidade de um número finito de componentes heterogêneos. "Num conceito, há, no mais das vezes, pedaços ou componentes vindos de outros conceitos, que respondiam a outros problemas e supunham outros planos." (DELEUZE; GUATTARI, 1992, p.26). Para os filósofos franceses, "todo o conceito, tendo um número finito de componentes bifurcará sobre outros conceitos, compostos de outra maneira, mas que constituem outras regiões do mesmo plano, que respondem a problemas conectáveis, participam de uma co-criação" (Ibidem, 1992, p. 30).

No ponto de ideação, os novos idealistas realizam a "experiência do pensamento" como criação. Para exercer essa experiência, é necessário que o que impulsiona a startup: i) realmente impulsione e afete o novo idealista; ii) que, realmente, seja social. Um problema que exija ação e solução; iii) que realmente impulsione a produção de uma modelagem para solucioná-lo. 


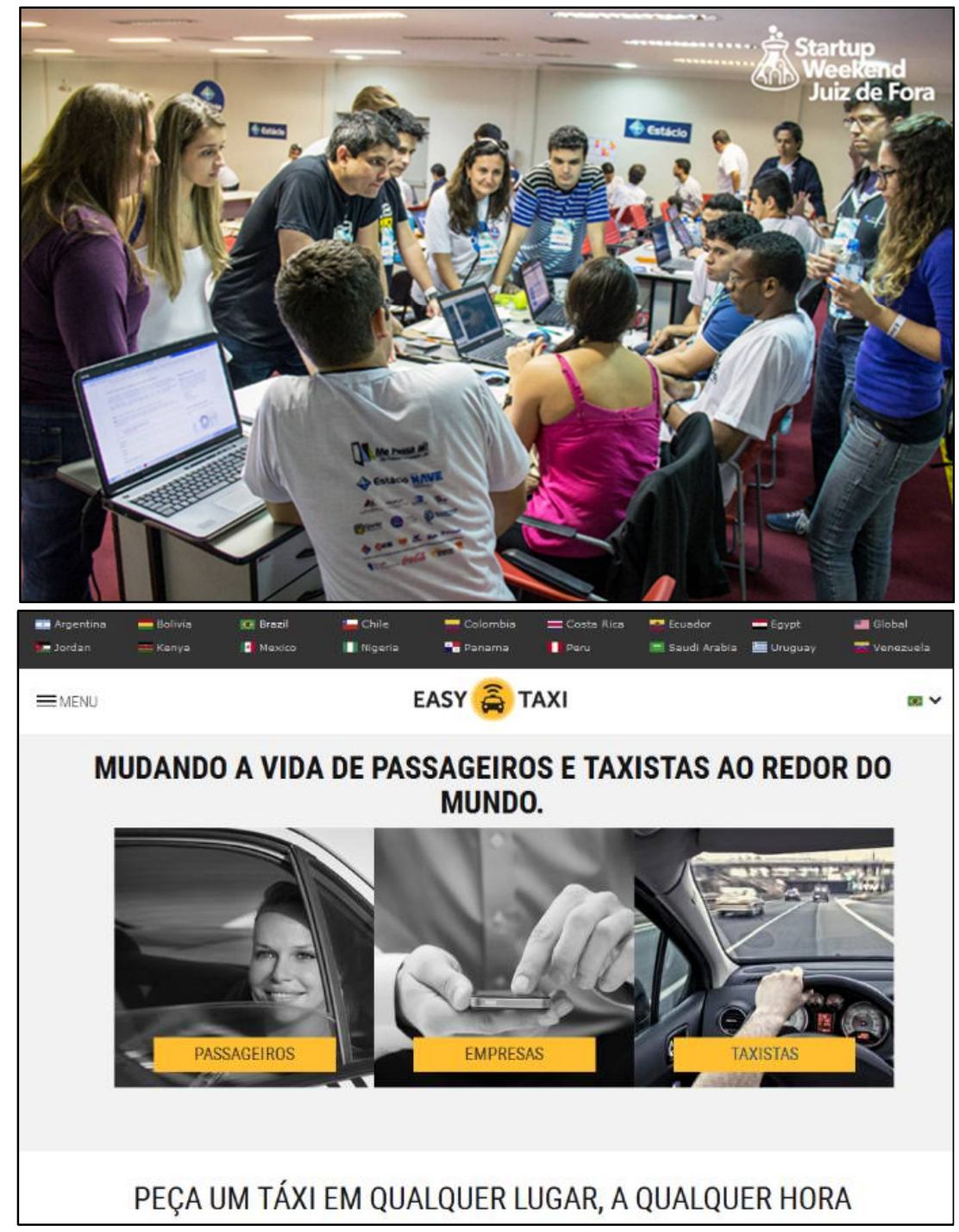

FIGURA 31. STARTUP WEEKEND NO BRASIL ${ }^{113}$

Na primeira figura, edição do evento-competição em Juiz de Fora - MG. Na imagem abaixo, o sitio da startup pioneira no serviço de chamada de táxi na América Latina, criada dentro do evento e o maior case de sucesso da competição no Brasil.

No estágio embrionário, muitos novos idealistas participam de eventos-competição direcionados para quem quer iniciar uma startup, reconhecendo nesses eventos a oportunidade para dar os primeiros passos em direção à execução de suas ideias. No mercado brasileiro existem diversas competições de startups, com modelos que sofrem variações em seus formatos, duração, premiação, benefícios e públicos. Um evento bastante disseminado no Brasil

113 Primeira imagem disponível em: <http://blog.chicorei.com/startup-weekend-juiz-de-fora/> Imagem abaixo corresponde a um print screen da página principal do site <http://www.easytaxi.com/br/> Acessos em 01 mai. 2016. 
é o Startup Weekend ${ }^{114}$. Com presença global, o evento estadunidense se realiza por meio de uma rede global de pessoas e empresas dedicadas a fomentar o empreendedorismo. O evento permite, na prática, que os novos idealistas compartilhem, maturem a sua ideia, coloquem-na em ação e formem times para começar a criação de uma startup em tempo recorde de 54 horas.

Os perfis inscritos no evento são, aproximadamente, $50 \%$ de perfil técnico, como desenvolvedores, programadores e designers, e 50\% de perfil de negócios, como marketing e finanças. Entretanto, o evento é uma experiência que atende tanto um empreendedor serial como pessoas sem background em negócios. Os novos idealistas veem nesses eventos a possibilidade de viver uma experiência em que serão disponibilizados ferramentas e conexão com as pessoas e recursos próprios para dar um "pontapé inicial" na criação de seu negócio e descobrir os próximos passos. O evento, que tem três dias de duração, pode ser assim resumido:

- Dia (01) Meet, Pitch \& Team Up: momento onde as ideias de negócios são apresentadas em público, os participantes votam nas melhores ideias e são escolhidos os grupos de trabalho.

- Dia (02) Learn \& Work: mentores auxiliam as equipes durante todo o evento, onde os grupos trabalham com os recursos e suporte oferecido pelo evento no local para fazer as coisas acontecerem no local em um período curto de tempo.

- Dia (03) Present \& Choose: equipe realiza apresentação de cinco minutos de seus trabalhos para corpo de jurados especializados.

No evento, os empreendedores realizam um trabalho coletivo para colocar suas ideias em ação e transformá-las em um modelo de negócio, refletindo sobre os elementos de sua ideia e respondendo questões como: Qual a solução e o problema a ser resolvido? Como suas ideias resolvem esse problema? Quem são os clientes? Qual o tamanho do mercado? Como ganhará dinheiro com sua ideia? Para esses novos idealistas é a oportunidade de testar o potencial de seus produtos, dar visibilidade a suas ideias para adquirir usuários, coletar feedback qualificado, fazer networking, encontrar time, bem como atrair mídia e early adopters.

Lançada em abril de 2012, a startup brasileira Easy Taxi nasceu em junho de 2011, durante o Startup Weekend Rio, no Rio de Janeiro. Em seu depoimento, Tallis Gomes fala de sua experiência no evento-competição e a afetação sofrida no ponto de ideação.

A primeira ideia era um aplicativo de ônibus e nessa mesma competição eu pivotei para fazer o aplicativo de táxi, porque a minha ideia de aplicativo de ônibus foi invalidada por um dos mentores, que disse: olha o Google já está fazendo isso e vocês precisam mudar a ideia. A gente estava sem ideia e tínhamos de sexta a domingo para montar o MVP

${ }^{114}$ Maiores informações disponíveis em: 〈http://startupweekend.org/> Acesso em 11 jun. 2016. 
(mínimo produto viável). Aí eu esperei meia hora na sexta-feira para pegar um táxi e nada. Então liguei para cooperativa para cobrar o taxi e ela disse: olha não vai ter táxi mais, não. Desci para tentar táxi na rua, não consegui e então veio a ideia: por que não usar geolocalização, que eu havia pensado para o aplicativo de ônibus, para o aplicativo de táxi? (informação verbal) ${ }^{115}$

Hoje a startup é uma plataforma mobile em um formato de marketplace, que conecta passageiros a taxistas. O Easy Taxi é o pioneiro no serviço de chamada de táxi na América Latina, com presença em 30 países e mais de 420 cidades, mudando a maneira de pedir um táxi ao redor do mundo. A conceitualização não é um ato de suspensão do pensamento. Mas uma ação sobre a realidade a partir do problema que essa mesma realidade produz. O conceito do produto ocorre tanto como um ato-pensado como um insight. Portanto, as ações do ponto de ideação fluem na zona cinzenta como um acontecimento.

115 Entrevista concedida por Tallis Gomes para o quarto episódio da série "Como eu comecei" produzida pelo portal Isto é Dinheiro. Disponível em: <http://www.istoedinheiro.com.br/videos/negocios/20140516/serie-comocomecei-tallis-gomes-criador-easy-taxi/2597.shtml> Acesso em 02 maio. 2016. 


\section{PONTO DE EXPERIMENTAÇÃO}

- A paixão continua mas com o desafio de fazê-la realizar-se no mundo. Não se trata de uma ideia na cabeça e uma máquina na mão, como no jargão do Cinema Novo de Glauber. Mas de uma junção de máquinas-seres-redes. À primeira vista, posso parecer dizer que a experimentação se trata de pôr a teoria em movimento. Mas não é de todo assim. Porque o novo idealista avançou na ideação, mas não se "livrou" de todo dela, uma vez que vai produzir redes, vai "cair no mundo", e precisa deste mesmo mundo para rearranjar, rever a ideia na ação. Embora a ideia esteja conceitualizada, um novo processo de afunilação, adequação, revisão ocorre justo no momento da experimentação. Como tal ocorre? O novo idealista vai ao encontro do mundo e lá realiza uma outra criação por meio de um processo muito novo na produção de ideias: a autoria coletiva em rede. Algo muito concreto começa de fato a ocorrer: o teste e validação dos produtos e das premissas do negócio.

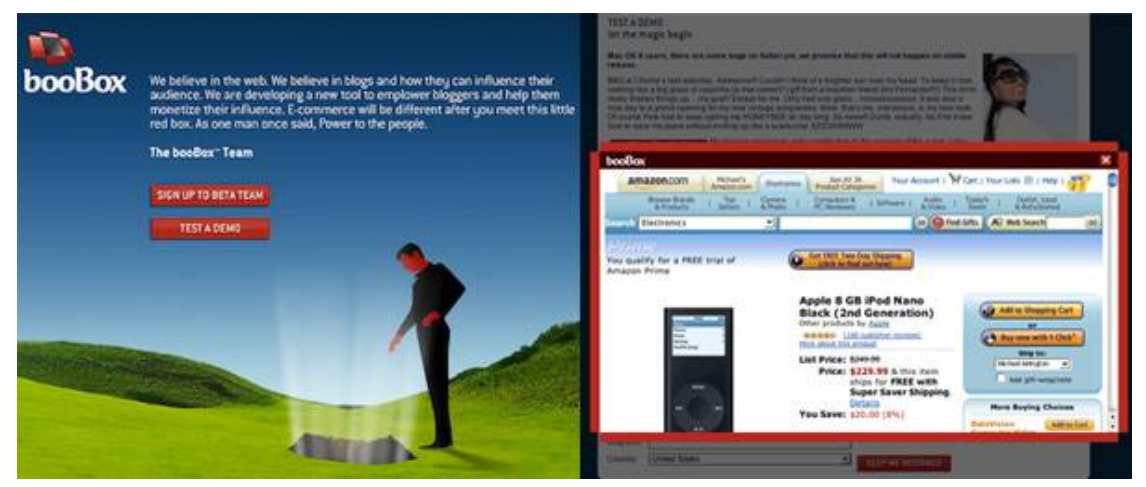

Figura 32. Protótipo FunCional da boo Box ${ }^{116}$

A página de experimentação lançada em dezembro de 2006 pela Boo-box não tinha uma linha de código. A splash page de pré-cadastro fazia a demonstração da proposta de valor da startup de oferecer propaganda contextual e oferecia um campo para coleta de e-mail dos produtores de conteúdo, interessados em saber mais sobre a ferramenta.

O ponto de experimentação das startups exige múltiplas interações e flexibilidade para mudanças rápidas e muitas vezes radicais. Trata-se de ações rizomáticas - com muitas entradas e saídas - sujeitas a uma dinâmica caótica. Nesta fase, ocorre uma intensa dinâmica de produção de redes que alimenta ações de cocriação e acaba por gerar um certo padrão de produção: na

116 Imagem extraída do Blog do Marco Gomes, fundador da Boo-box. Disponível em: http://marcogomes.com/blog/2010/historia-e-evolucao-do-codigo-de-programacao-da-boo-box/\#more-1489. Acesso em 01. Jun. 2016. 
prática, uma linha de ação sobre o caos. Embora esses momentos sejam tecidos juntos, em complementaridade, justaposição e inter-relações constantes, aqui faremos um esforço para percorrermos as ações no ponto de experimentação em três momentos, por uma questão de exposição. Assim, temos: (a) produção de redes - conexão com os ecossistemas; (b) cocriação: subjetivação - autorias coletivas; (c) objetivação: ação sobre a realidade concreta.

O ponto de experimentação é um momento de bastante informalidade, o momento que o novo idealista realiza o esforço para entender melhor a sua ideia, fazer adequações em suas propostas de serviço/produto e descobrir um modelo de negócio em torno da sua causa, reduzindo assim os riscos envolvidos na atividade. Sem um produto definido, sem uma modelagem de negócio comprovada e sem conhecer o mercado ideal, esses idealistas precisam conviver diariamente com a dúvida e pensar sempre no que é preciso ser feito em curtíssimo prazo. É um caminho de intenso aprendizado para esses potenciais empreendedores, que acionam o conhecimento, os afetos e a comunicação, tendo como missão descobrir como transformar suas 'pré-visões' em um negócio que seja sustentável.

\subsection{PRODUÇÃo DE REDES}

No momento de produção em redes, emergem três conceitos importantes que se tecem conjuntamente para a ação de produção das startups. Um deles é a criação de ecossistemas, que é precisamente a criação e gestão de canais. Dentro da produção das startups digitais existe a produção de canais, o que não se limita à criação de sítios e uso de suas mixagens de linguagens, mas inclui a criação de canais como um ato de complexidade que envolve não só a criação do ecossistema em um ponto de vista prático, como também o esforço para dar movimento e relevância a esses ecossistemas.

Nessas redes, há uma produção de conteúdos críticos, ou seja, a produção de um conteúdo reflexivo que passa pela inovação e pelo ideal de criar empresas com base na organização e acionamento do conhecimento que as pessoas já têm. Os conteúdos aqui são considerados críticos sobre o estabelecido, o que não significa o afastamento do tradicional, uma vez que se percebe aqui o capital se reestruturando de forma altamente criativa e tecnológica, conhecido por capital cognitivo (GORZ, 2005) ou capital imaterial (LAZZARATO e NEGRI, 2001). De forma concomitante, percebemos também a ocorrência de ações de gestão e pesquisa do ecossistema, onde os novos idealistas coletam e interpretam dados, bem como descobrem e atraem o seu público-alvo. 
As startups digitais necessitam de um território para demarcar sua ação essencialmente online. Uma das mais significativas ações nesta fase é a de criação de um ecossistema comunicativo - um site, um blogue, uma fanpage ou qualquer outra rede que estabeleça condições de comunicação, conhecimento e afetações. A partir deste território de experimentação, as startups começam a construir relações mais intensas, ficando estas também mais ativas. O produto vai ser validado (RIES, 2012) em um intenso processo de cooperação e aprendizado. Geralmente o território expõe as empreitadas de criação por meio de uma série de dispositivos como hangouts, webinars, posts. Nestas interlocuções, os idealistas ganham maturidade, expandem e, ao mesmo tempo, testam suas ideias.

O vlog da startup InEvent (post abaixo) nasceu com a intenção de compartilhar o dia a dia de criação de uma startup a partir do zero e a rotina da equipe que trabalha de maneira remota, de várias regiões do Brasil. Na web série produzida pelos novos idealistas, eles não só mostram o processo de criação da startup como também os seus modos de trabalho, comunicando os valores e a cultura da startup voltada ao aprendizado contínuo e ao engajamento.
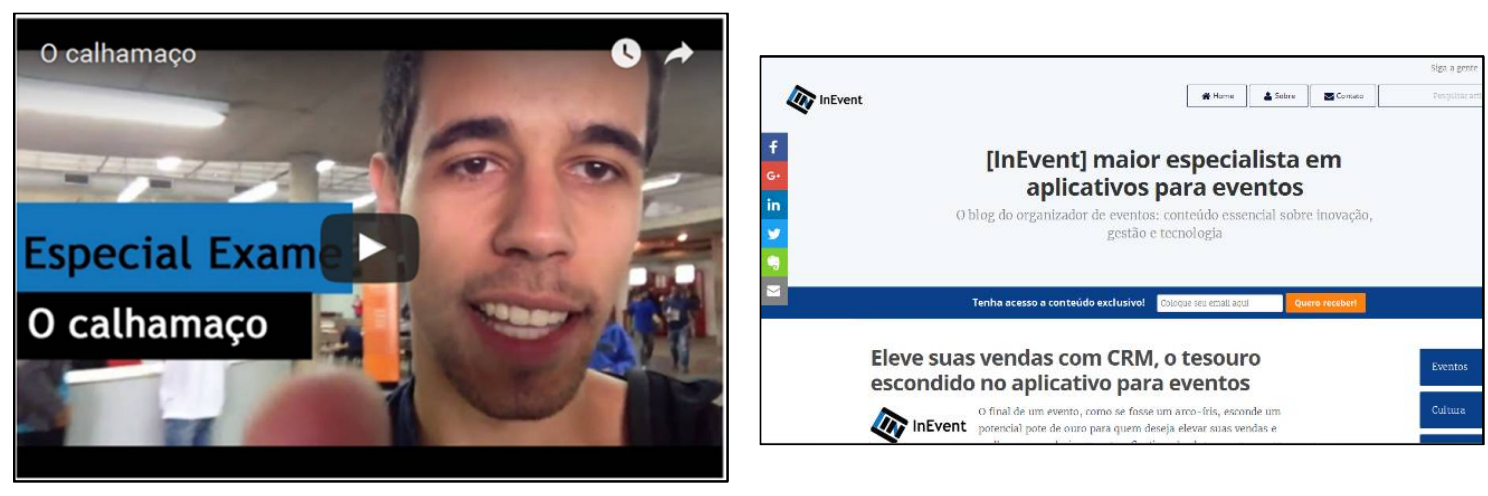

FIGURA 33. PRODUÇÃo DE REDES DAS STARTUPS ${ }^{117}$

O CEO da InEvent, Pedro Góes, grava capítulo de web série sobre o dia a dia do negócio. Criada em 2013, a Inevent oferece um aplicativo mobile para informação, comunicação e interação dentro de eventos, unindo seus organizadores, participantes e patrocinadores. Com a presença nas principais redes sociais, a startup produz comunicação desde o seu ponto de ideação. Seus canais ganham maturidade junto com a evolução da startup. Com a produção de conteúdo sobre evento no blogue, bem como produção de hangouts e webinars sobre o assunto em seu canal no Youtube, a startup se posiciona como veículo em seu segmento e hub de opinião.

117 Imagem extraída de reportagem no Portal Exame. Disponível em: http://exame.abril.com.br/pme/noticias/startup-faz-videos-contando-como-e-ter-um-negocio-inovador. Acesso em 01 Jun. 2016. Sítio do blog da startup. Ao lado, print do blog InEvent disponível em: http://blog.inevent.us/. Acesso em 02 jun. 2016. 
No momento de experimentação, as startups irão encarar aquele que é o seu principal risco: não encontrar mercado para sua ideia. Para minimizar este risco, as startups acionam a comunicação para auxiliá-las na tarefa de atrair e acelerar a experimentação com clientes em potencial. Nesta fase de legitimação, as startups optam pela comunicação online, como blogues, YouTube, Instagram, e-mail marketing e newsletters. Seu foco é gerar um relacionamento e uma audiência para o seu produto em desenvolvimento, sem gerar um problema de posicionamento futuro, uma vez que o seu produto/serviço ainda em criação sofrerá alterações ao longo do caminho para chegar a um alinhamento com o mercado.

Nesta fase, a produção de conteúdo é arte especial do idealista da startup com a audiência que vai ser gerada dentro de cada ecossistema. Trata-se de construir hipóteses e explorar os elementos que compõem a sua ideia. Aqui, o idealista apresenta seu ideal de produção, expondo o problema que se propõe a resolver e explorando a solução para resolvêlo. Este 'ideal de produção' é quase uma "eureca" para o novo idealista, uma vez que se trata mesmo do seu "saque" para fazer-se no mercado. Neste estágio, posicionam-se ideias, hipóteses, as formas de criação de negócios a partir das ideias. O que motiva o conteúdo é justamente o ideal de auto-empreendedorismo, no qual o conhecimento se torna capital imaterial e principal força produtiva.

Os novos idealistas ficam atentos para perceber se a audiência consegue captar a proposta de valor que estão tentando criar. Isto, no entanto, só vai se configurar com mais clareza no momento de cocriação (veja item seguinte), quando já ocorrem feedbacks a partir da prototipação das ideias, como veremos. Com efeito, a gestão do ecossistema está voltada para captar audiência, que normalmente funciona para o novo idealista como captação de early adopters. Com esta ação, a startup tem a oportunidade de explorar o problema identificado e a solução que se propõe a oferecer, realizando adequações da sua mensagem com a própria audiência e testando o entendimento do mercado com relação ao seu produto. Esses canais também permitem a geração de leads e facilitam a coleta de dados para entrevistas e experimentações, permitindo, assim, a atração desses primeiros usuários, para testes.

\subsection{COCRIAÇÃO}

É o momento de subjetivação, de autorias coletivas e de mobilização das intelectualidades das massas. Assim, aqui identificamos três propriedades importantes de descentramento, simbolização e produção de si. O descentramento é a subjetivação e a criação. Entendidas aqui não como algo que se produz na cabeça tão somente dos idealistas, mas de umuns e uns-uns. A noção de descentramento é aqui tomada para entender o ação de produzir em 
retículas. É um produzir descentralizado, que se realiza pelo acionamento do conhecimento das intelectualidades de massa que entram em ação. Assim, percebe-se a cocriação como autorias coletivas, uma vez que esses novos idealistas não pensam e nem criam isoladamente, mas com uma multiplicidade de elementos das mais diversas naturezas. Nesse movimento de cocriação, percebemos também aqui um momento de simbolização, entendido como a busca pela reprodutibilidade técnica como cocriação, um conceito de Walter Benjamin (2012), cada vez mais vivo diante do protagonismo das novas tecnologias. A reprodutibilidade técnica na cocriação é a capacidade de reprodução a qual a startup busca na zona cinzenta, ou seja, a busca por um modelo de negócio repetível e escalável. Assim, é a capacidade de reproduzir em escala o valor criado. Os novos idealistas ao produzir as suas startups, produzem a si mesmos, empreendendo-se ao passo que empreendem as suas ideias, produzindo na síntese e realizando uma produção para si.

A cocriação é um momento em que a startup se volta intensamente ao aprendizado com o seu cliente em potencial, buscando elementos e aspectos concretos de aprendizado a partir de um protótipo, ou seja, um produto mínimo viável (RIES, 2012). Mas vai ocorrer aqui um processo descentralizado de produção e criação que também é, ao mesmo tempo, teste dos seus próprios valores (veja item seguinte). A cocriação é uma contracorrente em relação ao establishment. Trata-se de uma linha de fuga em relação ao status quo, um descentramento da produção com novos valores.

O produto mínimo viável já tem um conceito e foi relativamente popularizado com o movimento lean startup - uma metodologia que busca, em menos tempo e com menos recursos, testar e validar ideias. Para isso, a metodologia de Lean Startup/Customer Development prevê a construção desse produto mínimo viável. Os novos idealistas produzem relações com os clientes para validar o seu produto. São momentos que envolvem comparações, observações, experimentações e intensa comunicação com esses clientes.

Nessa fase, os chamados earlyvangelist ou early adopters, consumidores alinhados com a visão do negócio, dispostos a comprar e testar produtos, mesmo ainda em desenvolvimento, são muito importantes. Suas experiências de uso e consumo serão o insumo para ajustar o produto. Este é um momento de cocriação, onde as startups trocam conhecimento com o ecossistema de startups e com os clientes, coletando dados e feedbacks para orientar o desenvolvimento no futuro, exigindo da startup a capacidade de interação rápida e percepção do cliente.

Nesta fase da Zona Cinzenta, a startup precisa descobrir um modelo de negócio que seja replicável e escalável (BLANK, 2014). Para validar o seu produto ou serviço com o consumidor, 
as startups começam a produzir relações com esses potenciais consumidores. As ações de relacionamento dessas startups são construídas a partir da necessidade de exploração dessa ideação, agora convertida em produto e modelo de negócio em experimentação. Essas relações variam em intensidades, dependendo do negócio e das formas de validação adotadas - formas de implementação e experimentação.

Embora as ações de relacionamento sejam importantes na fase embrionária, elas se tornam ainda mais relevantes e intensas no ciclo de maturidade ${ }^{118}$ mais avançado das startups, como o estágio subsequente de operação, em que as startups estabelecem relações com parceiros estratégicos, colaboradores e investidores, bem como na fase de crescimento, onde a startup precisa se relacionar dentro do ecossistema para caminhar dentro de um ambiente de startup, que apresenta diferenças quando comparado com o ambiente tradicional.

Em seu percurso embrionário, algumas startups buscam ser aceleradas e se associam a uma Aceleradora de Empresas. A aceleradora é um modelo de negócio recente no mundo. Para a ABRAII - Associação Brasileira de Empresas Aceleradoras de Inovação e Investimento ${ }^{119}$ (2014), as aceleradoras são normalmente entidades privadas que tem como principal objetivo apoiar e investir no desenvolvimento e rápido crescimento de startups, auxiliando-as a obter investimentos ou atingir o ponto de equilíbrio, ou seja, conseguir pagar suas próprias contas com as receitas do negócio. Comumente, as aceleradoras investem também um pequeno valor financeiro conhecido com survival money e, em contrapartida, tornam-se sócias da startup até o desinvestimento, quando sua participação é vendida para investidores ou empresas.

Os empreendedores encontram nessas organizações, programas que agregam capital financeiro e intelectual para potencializar as suas startups. Nestes programas, as startups se conectam a uma rede de investidores, mentores e empreendedores experientes, que as auxiliam na exploração da viabilidade técnica e econômica dos empreendimentos nascentes. Ao se conectar com este agente do ecossistema startup, o empreendedor busca nessa rede a expertise orientada ao mercado e a capacidade de investimento financeiro para direcionar e acelerar o desenvolvimento de seus negócios.

Fomos exponenciados pelo trabalho da aceleradora, as orientações que tivemos de fazer, as entrevistas de campo quando fomos à rua para pesquisa os nossos dois públicos (clientes e washers). Tivemos uma boa aceitação e, mesmo sem muitos detalhes, começamos a notar que tinha

\footnotetext{
${ }^{118} \mathrm{O}$ ciclo de vida das startups foi abordado no Capítulo III deste trabalho.

119 Estudo realizado pela incipiente ABRAII - Associação Brasileira de Empresas Aceleradoras de Inovação e Investimento associação, lançada em 2014, com o objetivo de medir o impacto real dessas aceleradoras com o ecossistema empreendedor brasileiro no período de 2012 a 2014 está disponível em: http://startupi.com.br/wpcontent/uploads/2015/07/ABRAII_em_numeros.pdf. Acesso em 13 abr. 2016.
} 
jogo. A partir daí começamos a desenhar os processos com a ajuda da aceleradora que também nos entregou todo o design pronto de como seria a aplicação. Contei também com um desenvolvedor de Curitiba que ele tornou isso verdade. E como eu sou um cara de TI, a gestão de projeto foi toda minha e fizemos o trabalho em conjunto com este desenvolvedor. E aí criamos a aplicação, fizemos o teste e colocamos no ar. Os testes de lavagem fizemos com os amigos. E colhendo seus feedbacks e fomos criando relacionamento (informação verbal) ${ }^{120}$.

As primeiras aceleradoras surgiram nos Estados Unidos, em 2005, construindo nomes como as aceleradoras $Y$ combinator, Techstars e 500 Startups, e produzindo resultados globais com startups aceleradas como Dropbox e AirBnB. O modelo das aceleradoras chegou ao Brasil em 2011, com variações de formatos e teses de investimento e tem demonstrado reconhecimento do mercado de investimento brasileiro. Segundo o estudo realizado pela ABRAII, no período de 2012 a 2014 houve um total de R \$ 88, 5 MM investido em empresas aceleradas, entre investimentos diretos e adicionais realizados pelas aceleradoras (ABRAII, 2015).

Embora pela própria definição e gênese de aceleradoras os programas de aceleração tenham como target principal as startups já validadas, em nossa investigação identificamos startups em seu estágio embrionário associadas a esses programas. No Brasil, as startups encontram diversos programas de aceleração - nacional, internacional, público, privado - com diferentes perfis e formatos. O País conta com a Start-Up Brasil, Programa Nacional de Aceleração de Startups, que é uma iniciativa de apoio às startups do Ministério da Ciência, Tecnologia e Inovação em parceria com aceleradoras. As instituições de ensino superior públicas e privadas também constroem redes e iniciativas de fomento ao empreendedorismo tecnológico com o desenvolvimento de programas de pré-aceleração gratuitos.

Embora a ABRAII não reconheça a fase embrionária como estágio adequado para uma startup participar de um programa de aceleração, na prática, percebemos que existem programas de aceleração direcionados para startups em early stage (estágio inicial). Estes programas são definidos como pré-aceleração e atendem às startups em estágio pré-operacional. Os caminhos para se candidatar em um programa de aceleração podem ocorrer por meio de candidatura direta nos sites das aceleradoras, ou por meio de indicação de pessoas da sua rede, ou até mesmo atendendo a chamadas de processos seletivos para seus programas de aceleração.

${ }^{120}$ Entrevista concedida por Abussamra, João. Cofundador as startup Wairon, plataforma colaborativa para serviços de passagem e lavagem de roupas. Entrevista V [jan. 2016]. Entrevistador: Ana Patrícia Santana. A entrevista na íntegra encontra-se transcrita no Apêndice E desta monografia. 

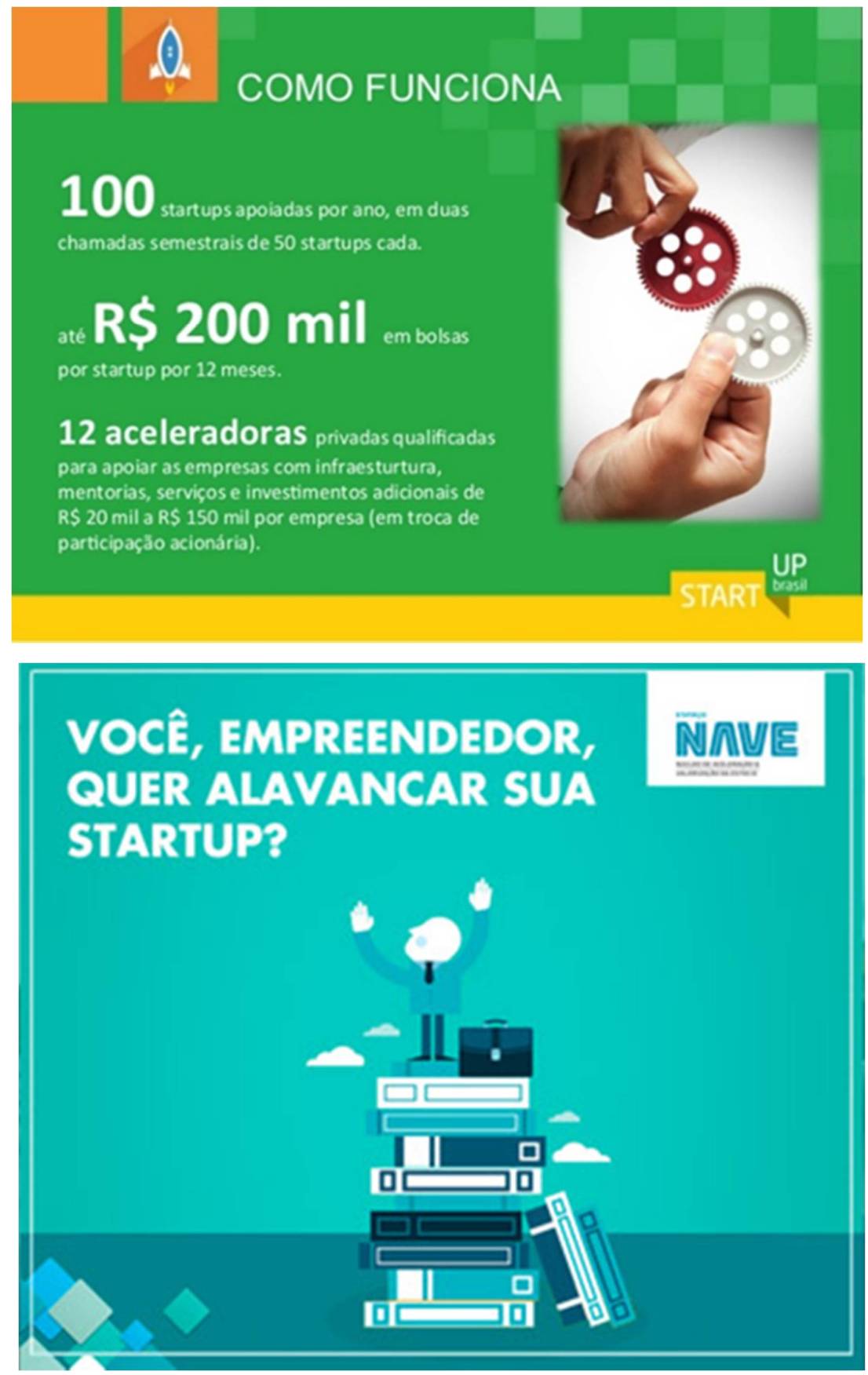

Figura 34. PROGRAMAS DE ACELERAÇão NO BRASIL ${ }^{121}$

Startup Brasil - Programas de aceleração do Governo Federal que seleciona startups de 0 a 4 anos de existência, explica seu funcionamento. Já a Nave é o programa de pré-aceleração do Centro de Ensino Estácio de Sá

${ }^{121}$ Imagens disponíveis respectivamente nos sítios: http://pt.slideshare.net/flaviosmarinho/slides-sobre-programastartup-brasil-mcti. Acesso em 01 jun. 2016 http://www.estacio.br/solucoescorporativas/link360/ed1214/materia-inovar.html. Acesso em 01. Jun. 2016 
Nessa fase de experimentação, os novos idealistas veem, na participação de programas de aceleração, a oportunidade de trabalhar a validação dos seus produtos e seus modelos de negócios. As aceleradoras são hubs que permitem à startup acessar uma rede de relacionamento qualificado e mentoria com empreendedores experientes, grandes empresas, oportunidades de negócios, reduzindo o tempo para validação do produtos e o encurtamento da busca por resultados financeiros.

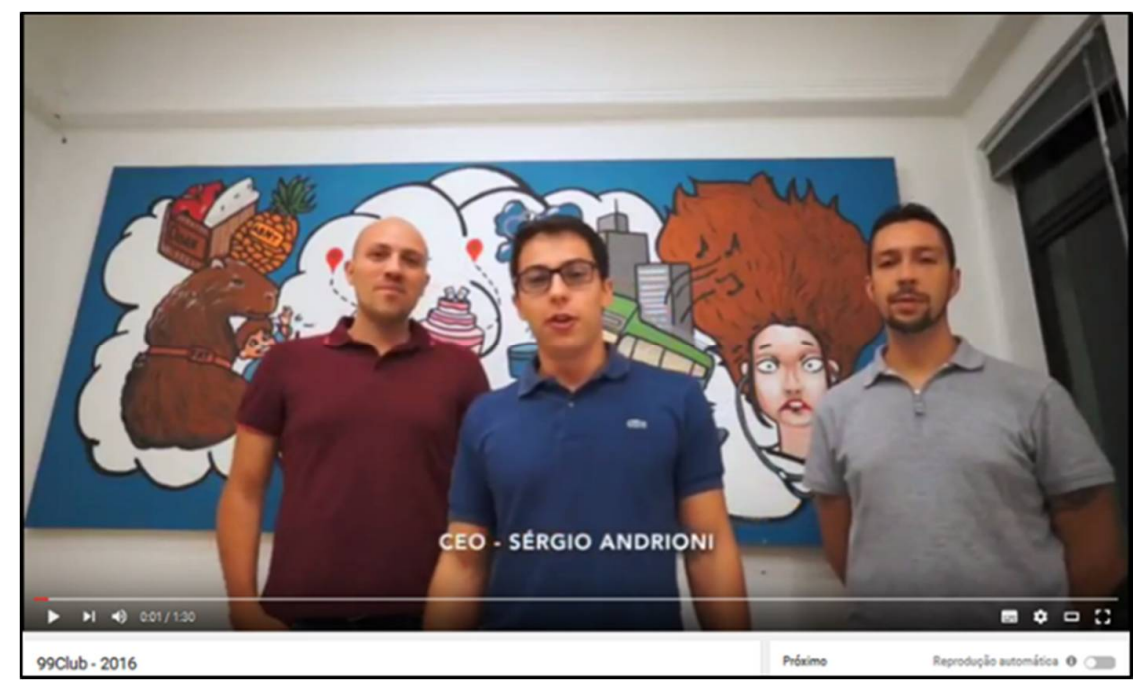

FIgURA 35. PROCESSO SELETIVO PARA ACELERAÇão ${ }^{122}$

Startup 99club posta vídeo como requisito para processo seletivo da aceleradora Startup Farm. O programa aceita startups em fase embrionárial

$\mathrm{Na}$ experimentação, o empreendedor trabalha com recursos muito reduzidos e a rede é um ativo fundamental. Neste momento, a rede de mentoria é importante, porque traz para perto do empreendedor pessoas que já passaram pela experiência e podem ajudá-lo a atravessar esta zona cinzenta de maneira mais rápida e com menos recursos.

Eu sempre tive uma vontade grande de ter a minha empresa e acima de tudo criar algo do nada. Algo que não existe. E criar algo que resolve um problema. Então eu senti a necessidade de ter alguém com mais experiência. Ter mentoria em aspectos do negócio que eu não dominava. Este foi o motivo principal pelo qual eu procurei um programa de aceleração. (informação verbal) ${ }^{123}$

122 Vídeo disponível em: https://www.youtube.com/watch?v=Y2zM5CcVp3Y. Acesso em 12 jun.2016.

${ }^{123}$ Fala de José Figueiredo, CEO da startup Zoomyard, uma plataforma para contratação online de fotógrafos e cinegrafistas, no vídeo produzido pela aceleradora de startup Wow. Depoimento disponível em: https://www.youtube.com/watch?v=9H79ygNZHK0. Acesso em: 16 jun. 2016. 
Nesse momento, a startup trabalha com uma relação de tempo bastante estreita, então a capacidade de execução é fundamental. Assim, a startup precisa de pessoas e recursos para cocriar com ela, tecendo complementariedade, onde as competências para programar, administrar e entender do mercado possam produzir um intelecto objetivado na execução e experimentação no negócio iniciante.

Os três fundadores tem um perfil puramente técnico. Então era imprescindível para nós, agregarmos de alguma forma outras expertises como o pessoal da administração, marketing e comercial. O maior benefício que nós tivemos até hoje com o programa de aceleração foi a mudança do nosso discurso comercial com os nossos clientes. Era um discurso praticamente inexistente. (informação verbal) ${ }^{124}$

No ponto de experimentação, geralmente a startup usa recursos próprios até encontrar como monetizar e encontrar um modelo de negócio sustentável. Embora a aceleradora conecte as startups com redes de investidores - investidores-anjo, fundos de investimento semente e fundos de venture capital, neste estágio embrionário o desenvolvimento de competência e potencial de execução são os benefícios intangíveis fundamentais para as startups que participam desses programas de aceleração.

As startups têm cada vez mais optado pelo espaços coworking em detrimento aos espaços convencionais de trabalho. Nestes espaços, a startup compartilha estrutura física com outras empresas e profissionais, atendendo a uma necessidade dos seus recursos iniciais limitados e equipe enxuta. Os idealistas não sabem de quantas pessoas precisarão e qual o espaço que precisarão no primeiro momento, então, dividir os custos de espaços de serviços é muito bom. Mas, não é só isso que faz as startups escolherem espaços coletivos de trabalho. $\mathrm{Na}$ fase embrionária de experimentação, as startups estão ávidas por conhecimento e demandam por feedbacks e rede de relações.

Segundo o censo coworking Brasil 2016 $6^{125}$, o País tem cerca de 378 espaços ativos. Este estudo também aponta que as startups, os serviços de internet e marketing totalizam $45 \%$ das ocupações destes espaços coworking brasileiros.

A minha vinda ao coworking Cubo abriu também minha cabeça para muitas coisas. Foi aí que eu passei a conhecer muita gente e espalhar o conceito e testar meu modelo lavando roupas de gente do Cubo. O ecossistema é muito inspirador, você começa a ter contato, indicações de oportunidades de negócios, indicação de stakeholders, várias possíveis parcerias que talvez eu

\footnotetext{
${ }^{124}$ Fala de Luis Fernando Duart, CEO da startup Busca Acelerada, site de busca especializado no mercado automotivo, no vídeo produzido pela aceleradora de startup Wow. Depoimento disponível em: https://www.youtube.com/watch?v=9H79ygNZHK0. Acesso em: 16 jun. 2016.

${ }^{125}$ O Censo Coworking Brasil 2016 está disponível integralmente em: https://coworkingbrasil.org/censo/. Acesso em: 13. Jun. 2016.
} 
não tivesse conseguido sozinho, muita troca de expertise, fazendo mentoria e sendo mentorado ao mesmo tempo. Fora a colaboração vivida em um espaço como esse... (informação verbal) ${ }^{126}$

Estes espaços coworking para startups vem crescendo como parte da estratégia de grandes empresas para se aproximar desse universo das startups digitais. Eles acabam por se tornar importantes agentes do ecossistema startup, criando densidade de pessoas, ideias e ajudando os novos idealistas a aprender, conectar e criar empresas.
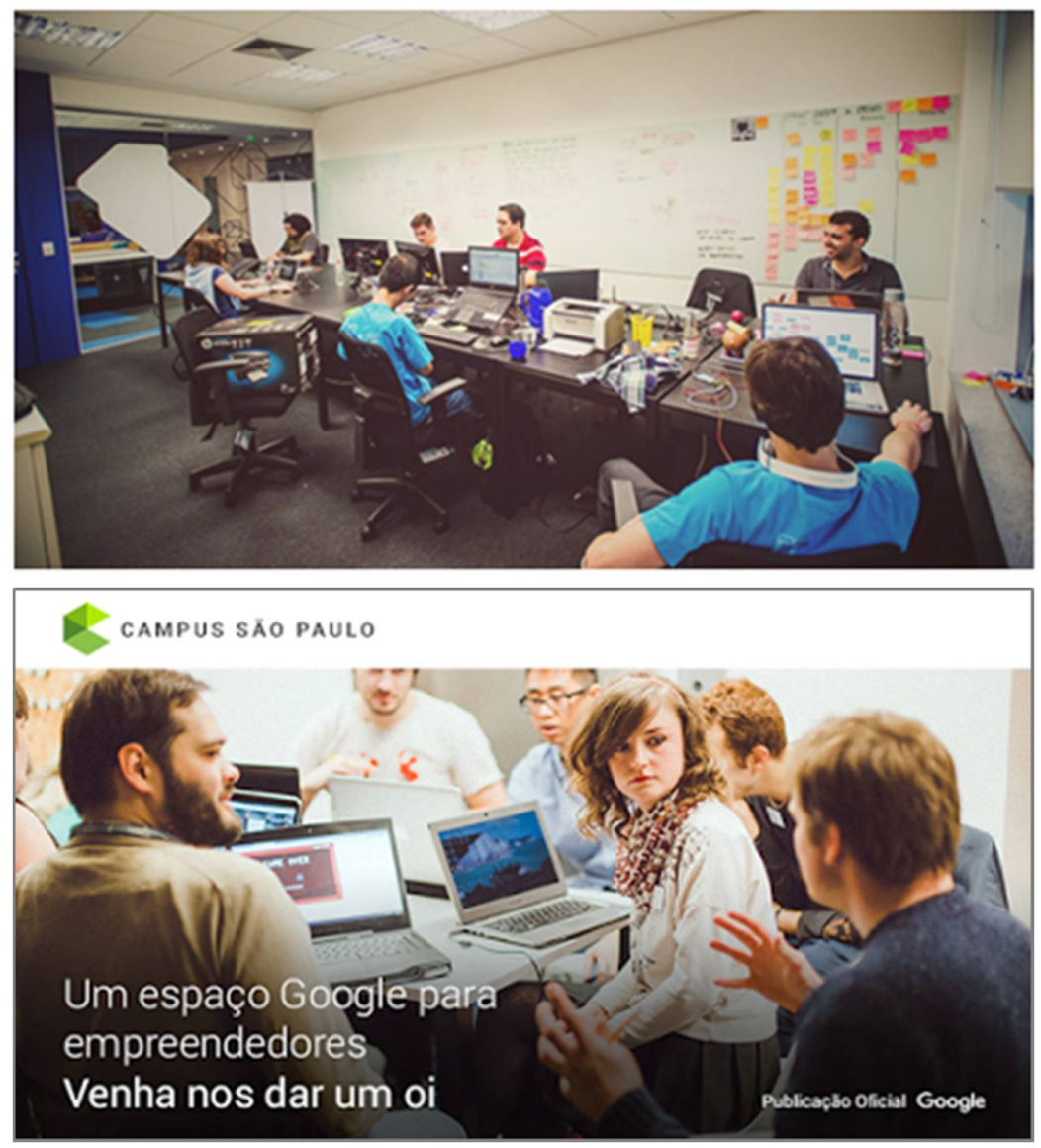

FIGURA 36. GRANDES EMPRESAS INVESTEM EM COWORKING PARA STARTUPS ${ }^{127}$ $\mathrm{Na}$ primeira figura, a equipe da Fin-Tech Controly, startup financeira residente do espaço cubo coworking, uma associação sem fins lucrativos de fomento ao empreendedorismo de tecnologia que conta com o apoio do Banco Itaú Unibanco, do RedPoint, e.ventures e com a parceria da Accenture digital, Ambev e Cisco. Na imagem abaixo o Campus São Paulo, um espaço Google para empreendedores no Brasil.

\footnotetext{
${ }^{126}$ Entrevista concedida por Abussamra, João. Cofundador da startup Wairon, plataforma colaborativa para serviços de passagem e lavagem de roupas. Entrevista V [jan. 2016]. Entrevistador: Ana Patrícia Santana. A entrevista na íntegra encontra-se transcrita no Apêndice E desta monografia.

${ }^{127}$ Imagem acima disponível em http://tutano.trampos.co/7547-saiba-como-e-trabalhar-no-controly/. Acesso em 10 abr. 2016. Imagem abaixo corresponde a print screen da página principal do site, disponível em https://cubo.network/. Acesso em 11 abr. 2016.
} 
$\mathrm{Na}$ fase de experimentação, o empreendedor pauta as suas ações acionando intensamente o conhecimento em rede, sincronizando-se continuamente com o outro e com os dados manipulados nos ecossistemas comunicativos. Trata-se de uma fase de alto aprendizado e autoaprendizado. Para isso, acessam redes autoproduzidas pela própria rede. São webinars, hangouts, portais e cursos online. Programas com durações e formatos diversos que ofertam uma extensa e regular produção de conteúdo e interações para o empreendedor startup, produzidos pelos próprios agentes do ecossistema. Os novos idealistas participam do desenvolvimento e coordenam um intelecto geral que torna acessível saberes e conhecimentos que os auxiliam na produção de suas startups, tendo como atividade, sobretudo, produzir-se a si mesmos.

Como seres da comunicação, os empreendedores encontram na rede o seu território, seus meios de produção e também seus meios de formação. Na rede, esses empreendedores se inter-relacionam e estão constantemente associando-se a outros idealistas. São empreendedores que se autoproduzem e produzem as redes de redes em que navegam para tecer seus empreendimentos. Na fase de experimentação, o processo de trabalho ocorre com cooperação e comunicação. O que conta em relação aos novos indivíduos da produção é a qualidade de coordenação, o discernimento, a capacidade de enfrentar o imprevisto, de identificar e resolver problemas. Para o novo idealista, interessa o 'saber vivo' que transita pela conectividade em rede, nos chats, blogs, hangouts com perguntas diretas, cujas respostas são incorporadas às práticas. As trocas informativas transversalizam os processos de experimentações, atuando como uma gestora das ações. O empreendedor é orientado por níveis de cooperação, mobilizações e movimento de multidões, multiplicidades.

Marcos Gomes, fundador da Boo-box e do Mova+, produz conceitos de empreendedorismo em vídeos curtos em um canal no YouTube, nomeado MBA. O título do curso é uma maneira bem humorada de transmitir conteúdo, sem qualquer relação com a certificação oferecida pelas universidades. É como se cada indivíduo se tornasse, antes de tudo, uma empresa, gerindo e criando sua competência, produzindo-se e autoproduzindo as redes de trabalho por onde as startups se realizam. Seus atores produzem conteúdo com o conhecimento que transita sobre a vida em todos os momentos. Faz-se abstração de todo conhecimento formalizável. O novo valor está em torno das conexões e conectividades. 


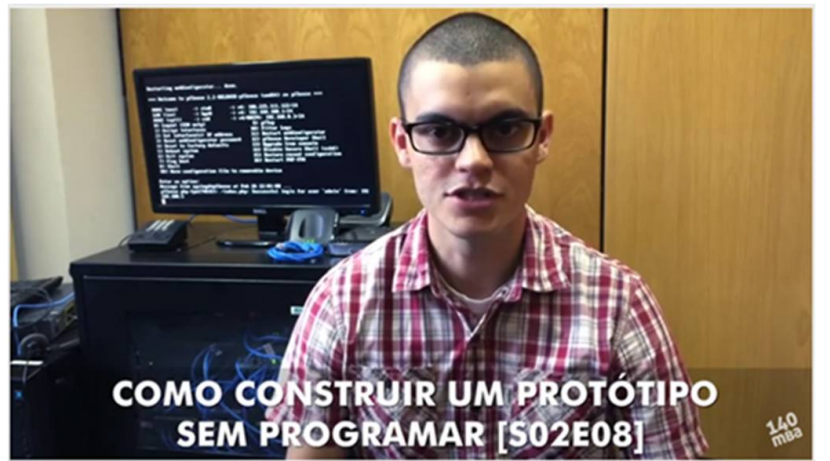

[s02e08] Como fazer um protótipo sem programar \#140mba III) 140 mbs com Marco comes

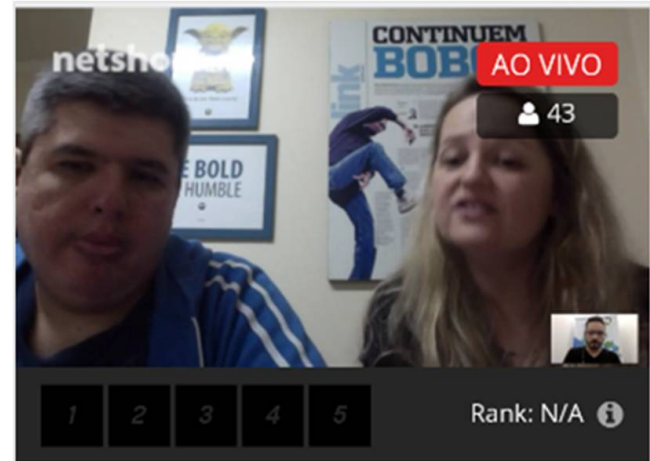

abswa ${ }^{2}+\ldots$ ABStalks - Go To Market abs

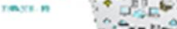
ข.ติด

FIGURA 37. NOVOS IDEALISTAS PRODUZEM CONTEÚDO ${ }^{128}$

$\mathrm{Na}$ primeira figura, episódio do $140 \mathrm{MBA}$. Canal que explora conceitos de empreendedorismo e conteúdo para empreendedores e startups. Em vídeos curtos produzido por Marco Gomes, fundador da Boo-box e do Mova Mais. O nome MBA é uma piada, deal with it. Na figura ao lado, AbsTalks, hangtalk com Horácio e Tatiana, casal de empreendedores fundadors da LedFace em conversa sobre Market oferecido pela ABSstartup.

A validação (RIES, 2012) é o marco que as metodologias lean startup e customer development (BLANK, 2014) adotam para fazer referência ao momento em que as startups provam a viabilidade do seu modelo de negócio e provam o seu conceito. Embora essas passagens estejam imbricadas, utilizaremos do tópico seguinte para intensificarmos a exploração das ações de testes das startups para provar o seu conceito.

\subsection{OBJETIVAÇÃO}

O teste no ponto de experimentação é um momento de coletivização, um momento de 'uns-uns'. Como filosofia desta ação, temos as polilógicas, ou seja, muitas lógicas em ação, decidindo conjuntamente. Naturalmente, por trás disso, estão os gestores e produtores do ecossistema. Também por trás destas ações está um processo precedente de cocriação. Neste momento, a subjetivação cede espaço para a objetivação, entrando em ação as polilógicas para

${ }^{128}$ Canal 140 MBA disponível em: https://www.youtube.com/user/140mba. Acesso em 13 jun. 2016. AbsTalks oferecido pela ABSstartup com conteúdo sobre startup oferecido gratuitamente por atores do ecossistema. Disponível em: http://abstalks.com.br/edicoes-passadas?utm_campaign=newsletter_base_junho1__2016\&utm_medium=email\&utm_source=RD+Station Acesso em 13 jun. 2016. 
fazer testes e ações de ajustes. Aqui se estabelece um ponto de fuga, uma linha de ação sobre o caos. Com efeito, é uma objetivação diante das multiplicidades. É isso que é este ponto dentro da objetivação. É um momento de testes e de ajustes. Mas, não é só isso. É também um momento de decisões sobre um caminho a seguir, um fazer. Eis aqui um conceito forte do ponto de experimentação: o fazer.

Diferente dos modelos tradicionais de criação de empresas, as startups têm como premissa a adoção de processos ágeis na concepção dos seus negócios. Para isso, no lugar de seguir processos lineares com separações claras entre a concepção do produto e o seu lançamento no mercado, as startups constroem os seus produtos dentro do cliente (BLANK, 2006).

Power Point e Excel aceitam tudo (...) Como eu vou prever um negócio que ainda nem existe? Então o que eu fiz na época foi ter uma noção de qual seria o meu custo para lançar. O planejamento é importante, mas mais importante é fazer, é a execução. É melhor lançar o protótipo com poucos recursos e tempo, do que ficar fazendo conta e depois a conta está errada (...) Aquela época eu queria lançar muito rápido e com muito pouco recurso. O protótipo resolvia $80 \%$ do nosso problema, meio um pareto 80/20. Não resolvia o nosso problema, mas dava para testar a água. (informação verbal) ${ }^{129}$

Para estes empreendedores, criar uma empresa compreende inicialmente testar e validar suas premissas de negócios com o cliente de maneira rápida. Para isso, eles abrem mão da clássica montagem de uma estratégia, no primeiro momento, que seja capaz de conduzir o passo a passo da empreitada. Esses empreendedores preferem o exercício de repensar continuamente a estratégia, buscando não repetir as ações que não apresentam resultados, buscando a flexibilidade para realizar correções e ajustes com agilidade.

No ponto de experimentação, o idealista enfrenta o desafio de encontrar como validar produtos/serviços com nível de inovação bastante acentuado. Ele precisa verificar rapidamente, e com pouco recurso, se as pessoas entendem a sua proposta de valor. Trata-se de um momento de testes onde, para provar o seu conceito, os idealistas estão atentos à construção de seu produto mínimo viável (PMV). Para isso, no lugar de ferramentas prontas de mercado ou sondagens, as startups constroem produtos simplificados e os introduzem dentro de um experimento que permitam a coleta de dados reais e não hipotéticos (RIES, 2012). Assim, sem

${ }^{129}$ Fala de Eduardo L'Hotellier, fundador e CEO da GetNinjas, em entrevista concedida ao Prof. José Dornelas para o empreende.vc, Escola de Empreendedorismo online. Disponível em: https://www.youtube.com/watch?v=KyLGO1ctTtQ. Acesso em 01 abr. 2016. 
muito planejamento prévio, a startup testa o seu produto e verifica se houve interesse na sua proposta de valor, podendo readequá-la ou recomeçar.

A gente não pode sair codificando. Já fizemos este erro na startup anterior, onde saiu tudo da nossa cabeça e nos saímos codificando. Mas como validar algo com um "q" de inovação tão acentuado? A gente criou um blog, Twitter e tudo que a gente ia aprendendo, a gente fazia um post e colocava ali. Em quatro meses tínhamos 10.000 pessoas no Twitter sem ter absolutamente nada. A gente tinha um blog apenas! E isso foi fantástico para validar as coisas. A Tatiana pegava o layout da página antes de programar, vinha com um pacote de trufas para Unicamp e, na saída do bandejão, pedia para alguém ajudar tendo em troca a trufa. Então as pessoas validavam. Elas nunca tinham visto o layout e servia para ver se elas entendiam a proposta de valor que estávamos passando. Ninguém entendia nada no começo. Perguntávamos o que é a LedFace e ninguém sabia falar. Até chegarmos ao ponto de dizer "agora estamos comunicado bem", levou quatro meses. (informação verbal) ${ }^{130}$

Por estarem inseridas em um ambiente de alto grau de incertezas e que oferece condições mínimas de controle, o experimento não se realiza a partir de ferramentas de provisionamento ou projeções: as startups criam um protótipo que é a versão básica do seu produto. Mesmo envolvendo quantidade de tempo e esforços mínimos de desenvolvimento, o PMV oferece valor suficiente para que as pessoas experimentem ou entendam a proposta de valor da startup, permitindo que o conceito seja testado.

Embora tenha usado de algumas ferramentas mais tradicionais para questionar as principais premissas antes de concretizá-las, para aprender sobre vários aspectos do seu negócio, Abussamra, cofundador da startup Wairon, seguiu à risca as orientações da metodologia Lean Startup (RIES, 2012) e construiu o seu produto mínimo viável para realizar um processo completo de aprendizagem. Da concepção da ideia à prototipação foram seis meses. Acompanhamos o seu marco inicial de experimentação em janeiro de 2016 e a evolução do aprendizado meses depois, em maio de 2016.

Aqui é um ponto em que as startups começam em um nicho pequeno para depois escalar e atingir nichos maiores. Neste momento inicial, sem estruturas operacionais, os idealistas muitas vezes realizam trabalho manual que os permite conhecer melhor o problema que sua startup pretende resolver e a solução que ela está desenvolvendo para atender este problema. Assim, esses novos idealistas desenvolvem expertise do negócio e conhecem melhor o seu

${ }^{130}$ Depoimento de Horácio Poblete, CEO da LedFace, plataforma de inteligência coletiva para ajudar a resolver os problemas do dia a dia, na série de web documentários VAI QUE DÁ: O perfil das startups brasileiras, realizada pela Endeavor Brasil, organização de apoio ao empreendedorismo de alto impacto no mundo. Disponível em: https://endeavor.org.br/vai-que-da-inteligencia-coletiva-ledface/. Acesso em 01 abr. 2016. 
produto antes de escalar. Neste momento, esses idealistas mergulham nos mundos que eles desejam conectar, atuando como fronte para descobrir seus early adopters.

Como a coisa ainda está com pouca escala, eu faço questão de ligar e confirmar o pedido, ver se está tudo bem. Quando tiver escalável isso terá que ser automático. Do ponto de vista da captação de pedidos. Quando o cliente se cadastra e não faz o pedido, eu cadastro eles numa ferramenta de CRM e crio metas do tipo: se ele se cadastrou na plataforma há uma semana e não fez pedido, eu ligo para saber se ele entendeu o modelo e se precisa de ajuda. Para aprender, tentar entender se ele entrou ou por curiosidade ou se ele tem a intenção de experimentar o serviço. Eu recebo as mais diversas mensagens: "sou um cara de tecnologia e estava testando a plataforma", ou "vou fazer o pedido próxima semana". Tento tirar informações deles. Já com os washers o contato é diário via Whatsapp, telefone ou email para saber o andamento dos serviços. (informação verbal) ${ }^{131}$

Existem variações na intensidade e no tipo de relações que são construídas, dependendo do tipo de validação do produto ou do tipo de negócio. Essas relações variam de acordo com a praticidade de implementação dos modelos ou a necessidade de construção de relações externas. Com modelos disruptivos de negócios, muitas vezes as startups precisam encarar o desafio de ensinar os clientes em potencial e construir com eles relações de confiança. Para Tallis, fundador do Easy Taxi, ir para as ruas era a única forma de validar o seu produto. Para ele, uma chance de fazer o aplicativo dar certo era educar o motorista de taxi do Rio de janeiro a ter smartphone. Foram muitos churrascos no sindicato dos taxistas e jogos de bola no final de semana para fazê-los enxergar o aparelho celular como ferramenta de trabalho e gerar confiança em fazer parte do negócio da startup.

Eu ia para as ruas todos os dias. Lembrei-me que para os estrangeiros pegar taxi no Rio de Janeiro era muito complicado e taxistas cariocas tem uma fama ruim com estrangeiros. Nós compramos smartphones com o dinheiro da venda do meu carro e com dinheiro de alguns sócios e colocamos na mão dos taxistas. Isso porque, em 2011, o smarthphone era luxo para os taxistas. Tivemos um trabalho de educação do mercado, de mostrar que era uma ferramenta de trabalho. Era uma época complicada, com muito suor, entregamos estes smartphones e conseguimos 10 taxistas. Focamos na zona sul. Fui na porta de hostel e hotéis e perguntava aos estrangeiros se queriam taxi. Assim comecei a gerar corridas e consegui PR ganhando campeonato. Aí os early adopters começaram a usar. Eram muito poucas corridas, mas deu para aprender bastante do modelo e melhorar o software. (informação (verbal $)^{132}$

\footnotetext{
${ }^{131}$ Entrevista concedida por Abussamra, João. Cofundador das startup Wairon, plataforma colaborativa para serviços de passagem e lavagem de roupas. Entrevista V [jan. 2016]. Entrevistador: Ana Patrícia Santana. A entrevista na íntegra encontra-se transcrita no Apêndice E desta monografia.

132 Entrevista de Tallis Gomes, fundador do Easy Taxi concedida para Leo Kuba e Miguel Cavalcanti no videocast sobre empreendedorismo e cultura digital Man in the Arena. Disponível em: https://www.youtube.com/watch?v=qXlfJxoIZ1U. Acesso em 12 jun. 2016.
} 
Com um produto incompleto, a startup precisa ser ágil na coleta e adaptação do seu produto de acordo com os feedbacks dos clientes. A partir da interação do cliente com os produtos em experimentação, geram-se os feedbacks referentes a funcionalidade e a formas de comercialização, bem como produção de dados reais. Estas informações são imprescindíveis no caminho de ajustes e validação do produto. Embora as startups trabalhem muito no caos e no acontecimento, no ponto de experimentação a startup conta com o fato de ser digital. Para uma startup de tecnologia digital é possível rastrear e coletar dados. Assim, as imprevisibilidades das startups podem ser mitigadas pela possibilidade que a Internet permite de acompanhar instantaneamente os seus resultados e fazer interferências rápidas.

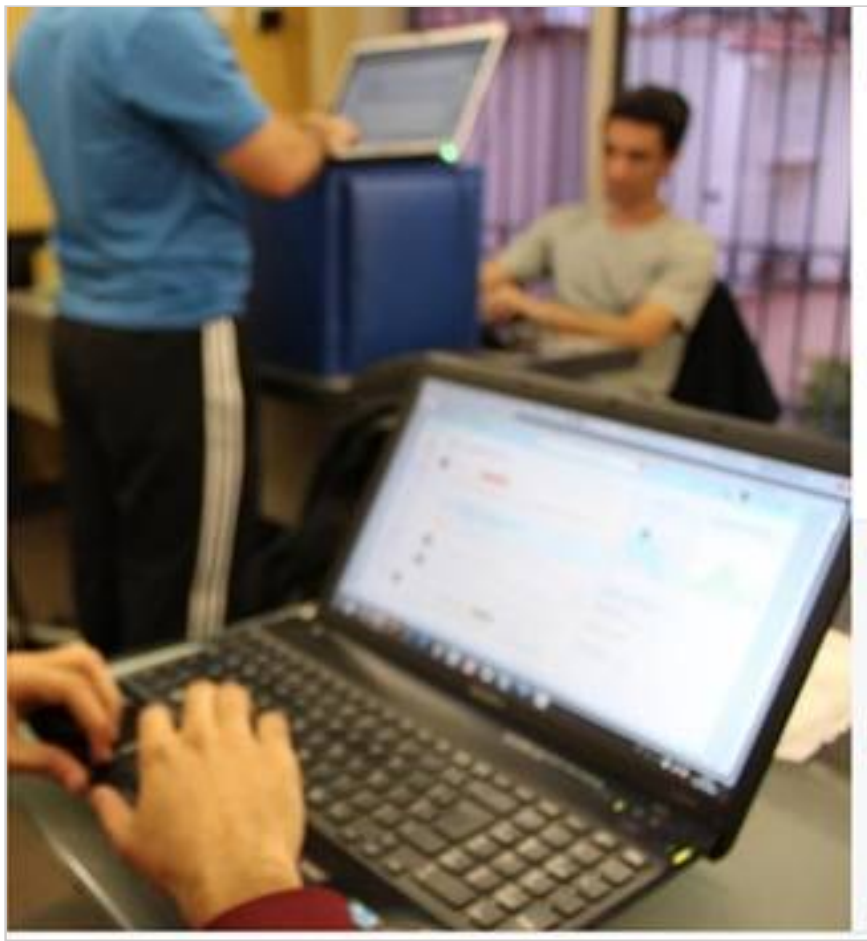

Qmágice

pszona cursda t ce aposta de 2012 \&

Em primeiro plano, o cid trabalhando. No segundo plano, fora de foco. o obieto de trabalho a nova plataforma do amágico. A gente garante que vocts v§o gostar $\mathrm{e}$

Aos pouquinhos vamos mostrando umas pinceladas delas pra vocés Quando vai ser a próxima? Ah. isso nem a gente sabel - com Gabriel Melo, 19or Aumeida Monigue Marques Alessandro Avoise De Assis Renzo lauccitelil Eduardo Macedo Olveira Thiago Feijalo Claudia Massei. Tácio Tavares e Elliot Rosenberg

it Cerfir aif Comentar $\$$ Conpartithar

O Thiago Fujaso e cutras 27 pessoas

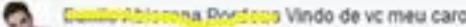
semore 6 uma surptesa e das mais criatias e. boast Sucessol 1 de spovit de 2012 as 17 s3 Curte $\Delta 1$ C...:-... valto Gabriet Um abracel 160 agosto 602012 as 2009 - Curst

Lievisuna sume Legaff queto ficar por dento das nowidades rsisrs Ide apalb de 2012 is 2101 curst

Ercowa um comentinc:

Figura 38. POSTAGEM dA STARTUP EM FANPAGE ${ }^{133}$

Programadores trabalham na nova versão da plataforma. Postagem comunica trabalho de melhoria na plataforma|

${ }^{133}$ Imagem extraída da fanpage da startup Qmágico. Disponível em: https://www.facebook.com/qmagico. Acesso em 01 jun. 2016 
$\mathrm{Na}$ zona cinzenta, o empreendedor procura pelo PMF (Product Market Fit). Esta é apontada como a maneira mais relevante para o empreendedor impactar e resolver problemas, ou seja, quando o produto que ele tem para oferecer se encaixa com a necessidade de mercado, encontrando uma demanda disposta a pagar por ele. A startup de educação Qmágico, que produziu um plataforma que oferece eficiência ao processo de aprendizagem através da personalização, realiza mudanças continuas e rápidas em seu produto, mantendo uma comunicação estreita nos seus ecossistemas.

Nessa busca, o produto com o qual o empreendedor entra na zona cinzenta não necessariamente é o produto o qual ela sai dela. Os novos idealistas entram com uma hipótese de produto e modelo de negócio para testá-la. Nesta experimentação, as lições clássicas dos MBAs parecem não dar conta dos desafios apresentados pelo empreendedorismo high tech. Isso porque as lições úteis são aprendidas na prática, na captação de saberes vivos e em um intenso processo de experimentação e aprendizagem.

Eu comecei a Easy Taxi em um modelo totalmente diferente do que é hoje. Fizemos inicialmente um modelo que era focalizado em centralizar cooperativas. Não é este modelo que é como hoje. Eu gastei quase três meses fazendo o MVP (mínimo produto viável) e indo para a rua executar, até entender que o modelo em parceria com as cooperativas não funcionava. Nós queríamos cortar os intermediários. Vimos que o negócio era conectar o taxista. Eles eram nosso maior ativo! (informação verbal) ${ }^{134}$

${ }^{134}$ Entrevista de Tallis Gomes, fundador do Easy Taxi concedida para Leo Kuba e Miguel Cavalcanti no videocast sobre empreendedorismo e cultura digital Man in the Arena. Disponível em: https://www.youtube.com/watch?v=qXIfJxoIZ1U. Acesso em 12 jun. 2016. 


\section{9. (IN)CONCLUSÕES}

Que diabo vim fazer aqui, neste lugar maluco? - me perguntava em voz alta. E, remando em silêncio, respondia: - Tentar sair daqui. De fato, nada colaborava para que eu achasse normal a paisagem a minha volta. Ondas completamente descontroladas, águas escuras, tempo encoberto, um barulho ensurdecedor. Por onde andariam as tranquilas águas azuis do Atlântico de que tanto ouvira falar? Sem dúvida, longe da África. (Amyr Klink, 2005).

Escrever uma conclusão nos exige um olhar para trás, nos exige forjar um momento de calmaria quando ainda navegamos em águas intranquilas. Já uma inconclusão nos conforta por aceitar que existe mais das zonas cinzentas da pesquisa a ser desbravado e que não chegamos a um fim. Neste momento, quando nos deparamos nas exigidas 'considerações finais', quando o corpo sente o cansaço da travessia ainda em curso e o cronograma nos faz lembrar mais uma vez que não necessariamente está comprometido com as razões da pesquisa, nos ancoramos nos 'achados' inconclusivos da investigação por uma mera formalidade, pela necessidade de apresentar um ponto final quando ainda estamos reticentes. Nesses 'aperreios', olhamos para trás, tentando ingenuamente relembrar o ponto de partida para sacarmos o nosso ponto de chegada. Percebemos que muito do que lá estava já não é tanto hoje! Isso porque a pesquisa nos leva para outros caminhos, outros mares, outras zonas cinzentas e também porque a pesquisa produz um novo pesquisador.

Eis-me diante de novas realidades e intenções: não me restringir ao porto seguro dos estudos categorizantes; não engessar meu pensamento nas lineares da administração e do mercado - rumos para os quais sempre fui treinada. Novas contracorrentes revelam o meu desejo de investigar a comunicação nas ações empreendedoras como algo além de produção de relações a externalidades, semi-externalidades, comunicação corporativa ou marketing. Atinei o desejo de sair da calmaria, das zonas de conforto para navegar em águas mais turvas.

Uma afetação muito particular que me faria produzir encontros, primeiramente com o Rede Rizoma, grupo de estudos em comunicação digital na Universidade Federal da Bahia e depois uma desterritorialização para São Paulo, interessada em uma disciplina de epistemologias reticulares do pesquisador de redes Massimo de Felice na Universidade de São Paulo. Agenciado que estava por outras redes, Di Felice produziu o meu encontro com o Centro Internacional de Pesquisa Atopos, uma rede de pesquisadores que me acolheram, me ensinaram e me inspiraram, provocando uma revolução em mim. Aventurei-me pelo estudo da 
comunicação, novos formatos, novos autores, novas teorias, um mundo de novidades que se agitam em mim, uma aventura inesquecível de produção de caminhos e também de descaminhos, razões de minhas inquietações mais profundas e novas inspirações.

Como bem afirma Deleuze (2010), o encontro é um grande ativador da criação. Com efeito, meu encontro com a Universidade de São Paulo, com o grupo Atopos, rompeu em mim uma estrutura de pensamento pré-moldada por uma ideologia de pesquisa quantitativa e suas implicações. Ao problematizar as startups como fenômeno de uma nova arquitetura social deparei-me com o objeto travessia tal qual as zonas cinzentas dos meus novos pensamentos.

Intrínseca aos novos modelos de negócios digitais, construí o conceito de zona cinzenta pra explorar o alto nível de criticidade vivido por seus idealistas no momento embrionário de suas criações. Percebemos que ali, nas fases embrionárias das criações, havia um movimento de uma multiplicidade que age em permanente cooperação. Passei a tentar perceber o seu fenômeno, nomear coisa, narrar os territórios de afetação.

Os meus recorrentes questionamentos também faziam referência a meu próprio deslocamento para uma experiência de pesquisa qualitativa dos tsunamis em minha vida. Assim, aceitando a incompletude e as limitações da pesquisa, faço um esforço para apresentar as considerações finais de uma obra inacabada sobre seres-rede em ação. Tomando como empréstimo as palavras de meu entrevistado Kaudoaki (2016), nele ancoro-me para revelar também meu intento mais alto (ser 'beta') e ao mesmo tempo o desejo de trilhar novos caminhos: "somos BETA e queremos ser BETA sempre. Acho que sempre seremos BETA. Isso porque queremos estar sempre experenciando caminhos, fazendo novos testes e ampliando o nosso trabalho".

A partir de múltiplos relatos de imersão, de vivências em espaços geográficos (espaços coworking) e não geográficos (ecossistemas comunicativos), e de interações com os 'sujeitosredes' (novos idealistas), procuramos produzir um tecimento sobre as ações das startups, buscando entender como de fato ocorre seu fenômeno em seus momentos iniciais de idealizações e criações, momento em que buscamos também perceber a emergência das startups, realizando um esforço de produção conceitual sobre esse tipo de empreendedorismo que se desenvolve em um ecossistema comunicativo de redes de redes.

Em um plano teórico situamos as startups como um fenômeno do imaterial, um arcabouço teórico que se propõe a explicar a imaterialidade do trabalho. Assim a investigação articulou as startups com os principais elementos dessa teoria como: o conhecimento como força produtiva (GORZ, 2005), a cooperação como principal categoria da contemporaneidade e 
a intelectualidade das massas como uma força produtiva fundamentada na comunicação (NEGRI, 2003).

Ao adentrarmos no praticismo das startups em seu early stage (estágio inicial), percebermos circuitos de criação intimamente relacionados com um modo de produção cada vez mais dependente das energias intelectuais e científicas (NEGRI, 2003). Alicerçadas na extraordinária potência produtiva das novas tecnologias digitais, no conhecimento não mais apreendido como apropriação privada, mas como um 'saber vivo', livre em rede (GORZ, 2005), e imersas em ecossistemas comunicativos com suas arquiteturas descentralizadas (RIFKIN, 2012; 2016), as startups digitais encontram, assim, condições para se produzirem. Uma produção que é tecida pelo acionamento do conhecimento, da comunicação e dos afetos como dispositivos de criação e orquestrada pela cooperação.

\subsection{O CONHECIMENTO COMO FORÇA PRODUTIVA}

Ao se produzirem em uma condição técnica que permite o acionamento de uma cadeia produtiva cada vez mais digitalizada, as startups digitais oferecem enquanto resultado de um trabalho analítico e simbólico, produtos e serviços em bits, com dimensões essencialmente imateriais. Isto é justamente o que Lazzarato e Negri (2001) e Gorz (2005) apontam como características da imaterialidade do trabalho na sociedade em rede.

É o conhecimento que circula como um 'saber vivo' que é acionado pelos novos idealistas nas tecelagens de suas criações. Um saber que não está preso às pessoas ou objetivado no interior de uma máquina. É um conhecimento digitalizável e, ao mesmo tempo, tecido junto por uma multiplicidade de singularidades e pelas relações do homem e das máquinas. Estas guardam em si uma potência capaz de projetar as criações dos novos idealistas em níveis exponenciais, por meio de uma capacidade de multiplicação indefinida que atinge uma razão proporcional inédita de custos desprezíveis.

A relação das startups com a técnica atinge um nível de dependência, em que é nesta condição técnica que repousam os elementos que as diferenciam de outros tipos de empreendedorismo: o potencial alto impacto (escalabilidade); instantaneidade (prototipação); transformação contínua (flexibilidade); aumento do custo não proporcional à escala de crescimento (exponencialidade); tendência a uma não definição (aberta a novas aplicações); rápida disseminação de suas criações (velocidade).

Assim como a técnica permitiu a reprodução em série das artes visuais, as tecnologias digitais, hoje, permitem a replicabilidade e a escalabilidade extrema das criações das startups 
em bits e átomos, a custos reduzidos por meio de queima de neurônios, manipulação de dados e automação de processos. É importante apontarmos também para a técnica que oferece a essas startups as condições para um agenciamento permanente de conhecimentos que podem ser armazenados, recuperados, manipulados (CASTELLS, 1999). Com o desejo de alto impacto e crescimento rápido, a técnica confere às startups o potencial de reaplicabilidade por meio de uma linguagem comum e do resultado de um trabalho que é, sobretudo, comunicação.

Entretanto, a emergência deste tipo de empreendedorismo, ligado ao advento das arquiteturas comunicativas em redes digitais e aos circuitos informativos, expressa não só a condição técnica da atualidade: trata-se também da expressão das transformações culturais qualitativas que se desenvolvem com a rede. As startups são filhas de uma temporalidade, espacialidade e dimensão qualitativa outras. São sistemas abertos que fluem pelos circuitos infocomunicativos.

Em muitos momentos, o trabalho confunde intencionalmente o termo novo idealista e a startup. Isso porque, no momento embrionário de suas idealizações e concepções, as startups e seus idealistas estão imbricados. Essas startups são os seus idealistas, movidos por uma força de uma trabalho sem hora marcada, sem cartão de ponto, e de grande intensidade. Um trabalho que não produz dicotomias entre o dentro e o fora. Nesses momentos mesmo de idealização e concepção, que a pesquisa chama de zona cinzenta, as startups são os novos idealistas, ou seja, auto-empreendendores em uma vida feita business. Esta vida-business é um misto de oportunidade e desejo de empreender, que motiva esses agentes livres a usar a força produtiva das máquinas e o conhecimento como 'saber vivo', fora dos muros e estruturas consagradas, fora de espaços geográficos circunscritos, para fazer business com tudo.

\subsection{A NATUREZA COMUNICATIVA DAS STARTUPS DIGITAIS}

As ações de criação das startups digitais estão assentadas em processos comunicacionais, sendo estes a base que orienta suas modelagens de negócios, seu desenho de produtos e soluções high-tech, bem como as relações de interações contínuas e de interdependência que estas iniciativas de inovação estabelecem com os diversos agentes em rede, relações sociais e circuitos info-comunicacionais, quando imersas na própria infraestrutura rede por meio do qual elas se produzem.

Com a participação cada vez mais intrínseca das tecnologias digitais, as startups criam negócios com modelos comunicativos de soluções pontuais para diferentes tipos de mercado. Essas startups digitais se produzem, essencialmente, por meio da dimensão comunicativa do 
trabalho imaterial e pela linguagem. Em seu interior, a comunicação não só permite que a engenharia do negócio startup funcione, como o just in time - sistema de adimistração flexível, cuja caracteristica principal é a técnica aplicada para coordenação da produção de acordo com a demanda, no tempo e no momento exato (SLACK, 2002), e como o lean production - produção enxuta que objetiva o alcance de melhor resultado nos processos produtivos, entregando o máximo de valor com a quantidade mínima de recursos possíveis (WERKEMA, 2012). Ela é também a dimensão mais essencial do trabalho das startups de manipulação de dados, trocas informativas e conexões. Além de ser muitas vezes o próprio resultado do trabalho de produção das startups, ou seja, a comunicação como o próprio core business (atividade núcleo) das criações startup.

As startups digitais acontecem no interior de um ecossistema com ambiências geográficas e não geográficas, cuja dinâmica se realiza através de relações de interações entre uma multiplicidade de sujeitos, espaços inteligentes, máquinas, interfaces, dispositivos e dados. As redes auto-organizáveis que compõem o ecossistema de startups são conhecidas dos novos idealistas, que buscam manter suas criações sempre abertas a esses espaços, construindo conexões e desconexões com essas redes, em um movimento fluido e contínuo de trocas infocomunicativas e produção de relações de interdependência.

A comunicação nessas iniciativas não assume uma relação opositiva startup-cliente, mas uma inter-relação múltipla entre startups, clientes, espaços coworking, investidores, inteligências, aceleradoras, arquiteturas informativas, realidades sociais, grandes empresas, territórios informativos, pessoas e tecnologias. Não há como nos afastarmos da sinérgica relação do empreendorismo startup com a cultura comunicativa resultante do advento das tecnologias digitais. As startups são redes conectadas a outras redes, produzindo-se à medida que produzem a própria infraestrutura do ecossistema startup em que estão imersas. Seus produtos são eles mesmos redes de produção.

As startups acompanham o ritmo de sucessivas e rápidas evoluções da Internet para construir produtos e modelos de negócios comunicativos cada vez mais inovadores, assumindo assim, qualidades muito próximas da rede. A Internet teve o seu advento como uma consequência de fusões singulares de cooperação, alta tecnologia e inovação assim como o que ocorre nas startups digitais. Na nova geração dos negócios digitais, a comunicação não funciona tão somente como uma ramificação, um braço ou um departamento como porta de externalidade com o mercado, até porque não há uma externalidade. A comunicação participa como elemento fundamental dos processos que as envolvem. 
Parece-nos que tais singularidades apresentam incompatibilidade com a lógica cartesiana do modelo moderno tradicional de empreendedorismo, subvertendo sua forma sistêmica, centralizadora, previsível e linear ao apresentar, de maneira abrangente, dimensões comunicantes, reticulares e conectivas. As ações infocomunicativas protagonizam essas práticas, participando intensamente em todos os momentos do processo.

Nessa iniciativa, as relações de semi-externalidade que enxergam portas de acesso ao externo, ao mercado, sofrem profundas alterações. Essas iniciativas já nascem com fronteiras permeáveis, onde as informações circulam em fluxo, em múltiplas entradas e múltiplas saídas e sem claras separações do dentro e do fora. Como nativas digitais, gozam de sua competência para navegar nos espaços comunicativos, circulando em uma infraestrutura inteligente por elas construída e por meio da qual elas encontram condições para se realizarem.

\subsection{A COOPERAÇÃO COMO ‘ASAS’ DA CRIAÇÃO}

Nos seus estágios embrionários, as startups produzem o seu tecimento através de um emaranhado de conexões e de trocas permeadas por ações de cooperação. Logo nos seus primeiros momentos de ideação e experimentação, as startups se aproximam desse ecossistema e começam a desenvolver conexões com suas redes de redes. Estas conexões se tornam cada vez mais fortes na medida em que as startups avançam para ciclos de maior maturidade de suas criações. Elas recorrem à cooperação presente nesse ecossistema a cada passo, para avançar e minimizar os riscos diante de tamanhas incertezas em que são criadas.

Nessas redes, o conhecimento e o afeto são compartilhados de forma contínua e se entrelaçam produzindo ciclos de criação coletiva. Nas multiplicidades de encontros espontâneos ou programados nos espaços coworking, espaços individuais de trabalho, fóruns, blogs, hangouts, webinars, meetings, eventos-competição, cafés e social networking, os novos idealistas compartilham intelecto e capacidades subjetivas como motor para suas criações que se configuram em uma obra de muitos.

A informalidade e descontração que permeiam os seus espaços de trabalho refletem uma não-separação entre a temporalidade trabalho e não-trabalho de sujeitos-redes que se organizam de modo independente e por meio de uma cooperação social do trabalho (LAZZARATO; NEGRI, 2001). Para suas criações são acionadas suas subjetividades, seu corpo, compartilhando experiências, recursos e expertises no momento 'eureca' e de alto aprendizado das startups. Assim, buscam capturar um saber-fazer, evitando repetição de erros, retrabalhos, 
compartilhando competências complementares e ganhando velocidade em direção ao desenvolvimento de suas ideias de negócio.

Sem espaços circunscritos e isolados, mas imersos em um diagrama rede, as startups e os diversos agentes do seu ecossistema se auto-organizam produzindo criações em forma de interatividade cooperativa em rede de comunicação, conhecimento e afetos, produzindo-se por meio de um tecido comunicativo e de uma estrutura de cooperação produtiva na criação de seus produtos-redes.

$*$

Sempre desconfiei do pensamento das startups como dispositivos de desafio ao status quo, um fenômeno de disputa ou separação entre o velho e o novo, entre o presente e o passado. Ao adentrarmos no seu praticismo, o fenômeno das startups digitais deixava-se perceber como um rearrumamento, como um fenômeno da própria sociedade em rede e de uma mudança profunda e qualitativa nas relações de trabalho; da desterritorialização dos espaços de produção; do protagonismo intenso das novas tecnologias; e do corpo como máquina de produção. Não uma ruptura com o estabelecido e consagrado, mas, sim, uma profunda transformação das formas do viver, que emerge dos protagonistas de seres-redes do mundo do empreendedorismo. Trata-se de construções de novos corpos, da cooperação como novas formas, outros fluxos e outros rumos.

Quando observamos as relações entre o fenômeno das startups e o mundo tradicional dos negócios, serviços e das grandes empresas, percebemos um esforço crescente destes para se adaptar às startups e às suas modelagens enxutas, sua velocidade, sua flexibilidade, sua multiplicidade e sua capacidade de inovação. Um movimento de intenso aprendizado e adaptação do estabelecido ao novo modelo de produção que é o imaterial.

Atuando na beira da inovação com seus produtos e modelos de negócios e com o objetivo de gerar alto impacto, as startups, em grande medida, buscam atuar em mercados robustos ou naqueles com grande potencial de crescimento, criando novas experiências. Ágeis, com custos reduzidos e eficientes, as startups penetram em mercados consagrados ou constroem os seus próprios territórios, oferecendo diferentes tipos de soluções high-tech.

Com soluções entregues cada vez mais em bits que átomos, as startups se realizam pela manipulação de dados e em infraestruturas digitalizadas, comunicação, estruturas organizacionais enxutas e processos inteligentes de um trabalho humano-máquina. 
Esses novos corpos inteligentes provocam interpretações e reações diversas nos mercados tradicionais e institucionalizados. De concorrentes a parceiras, não raramente as startups enfrentam controvérsias em torno da regularidade das suas operações, convivendo com riscos regulatórios e sendo encaradas, muitas vezes, como corpos que desafiam o status quo. Fortemente marcadas pela participação de componentes mobile, cloud e social, estas startups constroem modelagem de soluções pontuais sobre a base do mercado tradicional, produzindose por meio da dimensão imaterial do trabalho hegenonizado pelo comando de máquinas.

Ao se produzirem em uma outra ecologia comunicativa, as startups pensam o digital primeiramente e realizam-se por meio de uma base imaterial de produção. Assim, acabam por projetar modelagens enxutas e comunicativas que não comportam intemediários e favorecem a conexão. Isso faz com que estas iniciativas consigam ofertar experiencias mais eficientes, mais rápidas e fáceis se comparada ao status quo. Entretanto, isso não reflete uma resultante de um planejamento estratégico para ocupar o espaço dos grandes players nos mercados que atuam, mas sim os efeitos de suas modelagens comunicacionais e sua engenharia enxuta. As startups se revelam como novos corpos emergentes do mundo-rede de produtos high-tech com uma produção imaterial.

As ideias de dicotomia entre o velho e o novo e até mesmo de ruptura intencional são enfraquecidas quando acompanhamos o crescente relacionamento de players do mercado tradicional com as startups digitais, principalmente com aquelas que se dedicam ao mercado B2B (Business to business ou Empresa para empresa). As grandes empresas realizam iniciativas das mais diversas como programas de inovação aberta, espaços coworking para startups e pitch corporation (evento que tem como objetivo apresentar Startups B2B com soluções inovadoras para grandes empresas) para conectar-se ao ecossistema de startups. Há um movimento de entender este mundo imaterial do auto- empreendedorismo e buscar formas de produzir transformações com ele.

O incipiente movimento de aproximação deste agentes tradicionais do mercado com as startups revelam não uma ultrapassagem ou ruptura, mas uma rearrumação, uma nova ordenação do existente, em que estas startups começam a ser percebidas como iniciativas inovadoras que podem contribuir para o amadurecimento dos mercados dominados pelas grandes empresas. Elas são os vetores de inovação nos modos de criação de empresas no mundo contemporâneo, contribuindo para reconfigurar a engenharia dos negócios no século XXI na medida em que o tradicional se adapta a um novo modelo de produção imaterial, hegemonizada pelo comando de máquinas, pelas relações em rede e pelas relações com um tipo de trabalho de dimensão essencialmente comunicativa. 
As nascentes de um modo imaterial de produção são ágeis, fluidas, redes. Os ganhos de produtividade e eficiência oferecidos pelo potencial produtivo e de escala lateral, provenientes do advento das tecnologias digitais, reduzem os custos envolvidos em suas operações e permitem crescimento tão dramático, que estes empreendimentos podem alcançar e até ultrapassar negócios tradicionais em um curto espaço de tempo (RIFKIN, 2016).

Certamente, podemos indagar se estes momentos que vivemos de forma tão radical com relação à contemporaneidade são uma profunda ruptura. O desejo de ruptura é o desejo de quem não se conforma com o status quo. Parece ser uma distopia ver as coisas mudando, mantendo sua base de apoio e de reprodução. Talvez, por isso, muitos queiram perceber o fenômeno das startups como uma ruptura e ascensão de uma nova economia. Nova, sim. Ruptura, não. Entretanto, ocorre o tecimento de uma nova arquitetura. É o que chamamos de paradigma-rede. Em contraposição ao paradigma território, lugar. Ao absorver as inteligências, as criações, o grande social que edificou o mundo moderno sinaliza suas asas fazendo-se também rede. Mas, o que há de mais significativo é o protagonismo dos novos idealistas. Ao fragmentar a produção e produzir sobre uma intensa cooperação, um novo ser emerge na contemporaneidade quebrando em 'átomos' as estruturas da produção. O que há-de-vir desta fragmentação? Toda projeção cai também numa outra zona cinzenta: aquela onde moram os anos deste século. 


\section{REFERÊNCIAS}

ABRAII - Associação Brasileira de Empresas Aceleradoras de Inovação e Investimento. Levantamento Aceleradoras 2012-2014. Publicado em: 2015. Disponível em: http://startupi.com.br/wp-content/uploads/2015/07/ABRAII_em_numeros.pdf. Acesso em 01. Abr. 2016.

Abramovay, Ricardo. Economia nas Novas Mídias. EcovoxTV, 2012. Disponível: https://www.youtube.com/watch?v=b_mJcVfFsv4. Acesso em: 22 jun. 2016.

Muito além da economia verde. São Paulo: Ed. Abril, 2012.

AbuSSAMRA, João. Entrevista V [jan. 2016]. Entrevistador: Ana Patrícia Santana. São Paulo, 2016. Apêndice E.

ABSTARTUP. Startupbase. Disponível em: Ver: http://startupbase.abstartups.com.br/startups. Acesso em 09 jul. 2016.

AbsTalks. Disonível em: https://www.youtube.com/watch?v=KyLGO1ctTtQ.

Acesso em 01 abr. 2016.

AlVAREZ, Johnny; PASSOS, Eduardo. Cartografar é habitar um território existencial. In: PASSOS, Eduardo; KASTRUP, Virgínia; ESCOSSIA, Liliana. (Org.) Pistas do Método da Cartografia. Pesquisa-intervenção e produção de subjetividade. Porto Alegre: Sulina, 2009.

AMYr, Klink. Cem dias entre o céu e o mar. São Paulo: Companhia das Letras, 2005.

Anderson, Chirs. A cauda longa. $2^{\text {a }}$ Ed. Rio de Janeiro: Campus, 2006.

Arruda, Carlos et. al. Causas da Mortalidade de Startups Brasileiras: O que fazer para aumentar as chances de sobrevivência no mercado? São Paulo: Fundação Dom Cabral, 2012. Disponível

em: https://www.fdc.org.br/blogespacodialogo/Documents/2014/causas mortalidade startups bra sileiras.pdf. Acesso em: 01 jun. 2016. 
BARROS, Laura Pozzana de; KASTRUP, Virgínia. Cartografar é acompanhar processos. In: PASSOS, Eduardo; KASTRUP, Virgínia; EscossiA, Liliana. (Org.) Pistas do Método da Cartografia. Pesquisa-intervenção e produção de subjetividade. Porto Alegre: Sulina, 2010.

BARABÁSI, A. Linked: how everything is connected to everything else and what it means for business, science, and everyday life. New York: Plume, 2003

Bauman, Zygnunt. Tempos Líquidos. Tradução Carlos Alberto Medeiros. Rio de Janeiro: Zahar, 2007.

BAWEns, M; Kostakis, V. Network society and future scenarios for a collaborative economy. London: Polgrave Pivot, 2014

BENKLER, Yochai. The wealth of networks: How Social Production Transforms Markets and Freedom. New Haven, CT: Yale University Press, 2006. Coase's penguin, or Linux and the nature of the firm. The Yale Law Journal. Vol 112, 2002.

BENJAMIN, Walter. A obra de arte na época de sua reprodutibilidade técnica. Tradução: Francisco de Ambrosis Pinheiro Machado. Porto Alegre: Zouk, 2012.

BLANK, Steve. Why Governments Don't Get Startups-Or, Why There's Only One Silicon Valley. Website Xeconomy. Publicado em: 1 set. 2011. Disponível em: http://www.xconomy.com/san-francisco/2011/09/01/why-governments-dont-get-startups-orwhy-theres-only-one-silicon-valley/?single page=true\#. Acesso em 01 jun. 2016.

. What Do I Do Now? The Startup Lifecycle. Weblog Steve Blank. Publicado em: 12 fev. 2015. Disponível em: https://steveblank.com/2015/02/12/what-do-i-do-now/ Acesso em 14 mai. 2016

The Democratization of Entrepreneurship. In: Conference on Entrepreneurship. Stanford: 2011. Disponível em https://www.youtube.com/watch?v=nH7TAcqGko. Acesso em 19 dez. 2015. 
Por que o movimento lean startup muda tudo. Harvard Business Review.

Publicado em julho 2013. Disponível em: http://hbrbr.com.br/por-que-o-movimento-leanstartup-muda-tudo/. Acesso em: 13 mai. 2016.

The four Steps to the epiphany: Successful Strategies for Products that Win. North Carolina: Lulu Press, 2006.

; DORF, Bob Startup Manual do Empreendedor: o guia passo a passo para construir uma grande empresa. Rio de Janeiro: Alta Books, 2014.

BorUCHOwSKI, Marcio. Entrevista VI [nov. 2015]. Entrevistador: Ana Patrícia Santana. São Paulo, 2016. Apêndice F.

Brandão, Carlos R. O que é o método Paulo Freire. São Paulo: Brasiliense, 2004.

CAPRA, Fritjof. O ponto de mutação. São Paulo: Cultrix, 2004.

A teia da vida. São Paulo: Cultrix, 2001.

CAstells, Manuel. A sociedade em rede. Tradução de: Roneide Venancio Majer. 6 ${ }^{\mathrm{a}}$. São Paulo: Ed.Paz e Terra, 1999.

A galáxia da Internet. Tradução de: Maria Luiza X. de A. Borges. Rio de janeiro: Ed. Zahar, 2003.

CENTRO DE PESQUISA ATOPOS. Redes digitais e sustentabilidade: dinâmicas de interações com o meio ambiente em contextos digitais. ECA/UsP. Disponível em: https://www.youtube.com/channel/UCVT7GXnGQBTcYNiXZFF9fvg Acesso em 15 jun. 2016

ChARmaz, Kathy. A construção da teoria fundamentada: guia prático para análise qualitativa. Tradução: Joice Elias Costa. Porto Alegre: Artmed, 2009.

CHIAVENATO, Idalberto. Introdução à Teoria Geral da Administração: uma visão abrangente da moderna administração das organizações. $7^{\mathrm{a}}$ ed. Rio de Janeiro: Ed. Elsevier, 2003 
COCCO, Giuseppe. Introdução à $2^{a}$ edição. In. Lazzarato, Maurizio e Negri, Antônio. Trabalho Imaterial: formas de vida e produção de subjetividades. $2^{\text {a }}$ Ed. Rio de Janeiro: Lamparina, 2013.

COMPASS 2015. Global Startup Ecosystem Ranking 2015. San Francisco: 2015. Disponível em: http://blog.compass.co/the-2015-global-startup-ecosystem-ranking-is-live/. Acesso em: 14 ago. 2016.

Constine, Josh; HA, Anthony. Zuck Says Ads Aren't The Way To Monetize Messaging, WhatsApp Will Prioritize Growth Not Subscriptions. Tec Crunch. Publicado em: fev.2014. Disponível em: http://techcrunch.com/2014/02/19/whatsapp-will-monetize-later/ Acesso em 01 jun. 2016.

CORRÊA, E. Comunicação Digital e novas mídias institucionais. In: KUNSCH, M. (Org.). Comunicação Organizacional. V.1. Histórico, fundamentos e processos. SP: Saraiva, 2009. Reflexões para uma epistemologia da comunicação digital. Observatório Journal. $4^{\text {a }}$ ed. Lisboa, pp. 307-320, 2008.

COWORKING BRASIL. Censo coworking Brasil 2016. Disponível em: https://coworkingbrasil.org/censo/. Acesso em: 13. Jun. 2016.

CREMAdeS, Javier. Micro poder: a força do cidadão na era digital. Tradução: Edgar Charles. São Paulo: Editora Senac São Paulo, 2009.

Deleuze, Gilles; PARnet, Claire. Diálogos. Tradução de: Eloisa Araújo Ribeiro. São Paulo: Ed. Escuta, 1998.

Diferença e Repetição. Tradução: Luiz Orlandi e Roberto Machado, Ed. Relógio D’agua, 2006

Deleuze, Gilles; GUATTARI, Félix. O que é filosofia? Tradução de: Bento prado Jr e Alberto Alonso Muñoz. $3^{\text {a }}$ Ed. São Paulo: Editora 34, 2010.

Mil platôs: capitalismo e esquizofrenia. Vol. 1. Rio de Janeiro, Ed. 34, 1995

Kafka: por uma literatura menor. Tradução: Júlio Castañon Guimaraes. Rio de Janeiro: Imago Editora Ltda, 1997. 
DI FELICE, Massimo. Do público para as redes. A comunicação digital e as novas formas de participação social. São Paulo: Ed. Difusão, 2008.

Net-ativismo e ecologia da ação em contextos reticulares. Salvador: Compós, 2013

Paisagens pós-urbanas: o fim da experiência urbana e as formas comunicativas do habitar. São Paulo: Annablume, 2009.

. TORRES, Juliana; YANAZE, Leandro. Redes digitais e sustentabilidade: as interações com o meio ambiente na era da informação. São Paulo: Annablume, 2012.

Pós-complexidade: as redes digitais vistas a partir de uma perspectiva reticular. Revista IGH online. Publicado em: 11 nov. 2011. Disponível em: http://www.ihu.unisinos.br/entrevistas/500515-pos-complexidade-as-redes-digitais-vistas-apartir-de-uma-perspectiva-reticular-entrevista-especial-com-massimo-di-felice. Acesso em: 10 jun 2016.

Redes Sociais Digitais, Epistemologias Reticulares e a Crise do Antropoformismo social. Revista USP, n92, p.0-19, dez/fev.2011/2012.

Di KERCKHOve. A pele da cultura. Investigando a nova realidade eletrônica. São Paulo: Annablume. 2009.

Kuba, Leo; Cavalcanti Miguel. Man in Arena. Entrevista com Marcos Gomes. Disponível em https://www.youtube.com/watch?v=OjgJJiBeOu4. Acesso em 01.abr. 2016

ENDEAVOR BRASIL. Vai que dá: A cara das startups brasileiras. Episódio 01. Minha vida. Publicado em: 1 Jul. 2014. Disponível em: https://endeavor.org.br/vai-que-da-o-maior-portalde-saude-e-bem-estar-brasil-minha-vida/. Acesso em 13 jun. 2016.

. Episódio 02. Kekanto.

Publicado em: 1 Jul. 2014. Disponível em https://endeavor.org.br/vai-que-da-kekanto/. Acesso em 09 jul. 2016.

. Episódio 03. Qmagico.

Publicado em: 1 jul. 2014. Disponível em https://endeavor.org.br/vai-que-da-transformandoeducacao-com-tecnologia-qmagico/ Acesso em 09 Jul. 
Episódio 04. LedFace.

Publicado em 2 jul. 2016. Disponível em: https://endeavor.org.br/vai-que-da-inteligenciacoletiva-ledface/. Acesso em 01 abr. 2016.

FELD, Brad. Startup Communities: Building an Entrepreneurial Ecosystem in Your City. New Jersey: Hoboken, 2012.

Fragoso, Suely; Recuero, Raquel; Amaral, Adriana. Métodos de pesquisa para internet. Porto Alegre: Sulina, 2011.

Gallo, Sílvio. Metodologia do ensino de filosofia: uma didática para o ensino médio. Campinas: Papiros, 2013.

. Deleuze e a educação. Belo Horizonte: Autêntica, 2003.

GLEICK, James. Caos: a criação de uma nova ciência. Rio de Janeiro: Campus, 1989.

GLEISER, Ilan. Caos e complexidade. A evolução do pensamento econômico. Rio de Janeiro: Campus, 2002.

GALEFFI, Dante. O rigor nas pesquisas qualitativas: uma abordagem fenomenológica em chave transdisciplinar. In: MACEDO, Roberto Sidnei; GALEFFI, Dante; PIMENTEL, Alamo. Um rigor outro: sobre a questão da qualidade na pesquisa qualitativa. Salvador, Edufba, 2009.

Gasque, Kelley Cristine G. D. Teoria Fundamentada: nova perspectiva à pesquisa exploratória. In: Suzana Pinheiro Machado Mueller. (Org.). Métodos para a pesquisa em Ciência da Informação. Brasília: Thesaurus, 2007, v., p. 107-142.

GOMES, Marcos. História e evolução do código de programação da boo-box. Blog. Publicado em 20 abr. 2014. Disponível em: http://marcogomes.com/blog/2010/historia-e-evolucao-docodigo-de-programacao-da-boo-box/\#more-1489. Acesso em 01. Jun. 2016.

Canal 140 MBA. Disponível em: https://www.youtube.com/user/140mba. Acesso em 13 jun. 2016

GRAHAM, Paul. Hackers \& Painters: Big ideas from the computer age. Canadá: O'Reilly media, 2008. 
Startup = Growth. Weblog Paul Graham. Publicado em set. 2012.

Disponível em: http://www.paulgraham.com/growth.html. Acesso em 27 jun. 2016.

GORZ, André. O imaterial: conhecimento, valor e capital. São Paulo: Annablume, 2005.

GubA, Egon; LINCOLN, Yvonna. Avaliação de quarta geração. Campinas: Editora da Unicamp, 2011.

Hwang, Victor; HorowitT, Greg. The Rainforest: the secret to building the new Silicon Valley. California: Regenwald, 2012.

Imagina COLETIVo. História \#47 Qmágico. Disponível em: https://www.youtube.com/watch?v=GrkI6STdIgc. Acesso em 30 jun. 2016.

INNIS, Harold. Empire and Communications. Lanham: Rowman \& Littlefield Publishers, 2007.

INVISION. Design Disruptors. Disponível em: http://www.b9.com.br/61040/design/designdisruptors-documentario/. Acesso em 17 jun. 2016.

IsEnberg, Daniel. The Big Idea: How to Start an Entrepreneurial Revolution. Harvard Business Review. Publicado em: jun. 2010. Disponível em: https://hbr.org/2010/06/the-bigidea-how-to-start-an-entrepreneurial-revolution/ar/1. Acesso em: 01 jun 2016

. The Entrepreneurship Ecosystem Strategy as a New Paradigm for Economic Policy: Principles for cultivating entrepreneurship. Babson Entrepreneurship Ecosystem Project. Publicado em: 11 mai. 2011. Disponível em: http://entrepreneurialrevolution.com/2011/05/11/the-entrepreneurship-ecosystem-strategy-as-a-new-paradigm-foreconomic-policy-principles-for-cultivating-entrepreneurship/. Acesso em 01. Jun. 2016.

Jenkins, Henry. Cultura da Convergência. $2^{\circ}$ edição. Tradução de Susana Alexandria. São Paulo: Aleph. 2008.

KAUdOAKI, Ricardo. Entrevista III [jan. 2016]. Entrevistador: Ana Patrícia Santana. São Paulo, 2016. Apêndice C. 
KASTRUP, Virgínia. O funcionamento da atenção no trabalho do cartógrafo. In: PASSOS, Eduardo; KASTRUP, Virgínia; EscossiA, Liliana. (Org.) Pistas do Método da artografia. Pesquisa-intervenção e produção de subjetividade. Porto Alegre: Sulina, 2009.

KAUfMan, Dora. O despertar de Gulliver: Os desafios das empresas nas Redes Digitais. Tese de doutorado- Escola de comunicação e Artes, Universidade de São Paulo, São Paulo. 2015

; ROSA, Erick. Empresas e consumidores em rede: Um estudo das práticas colaborativas no Brasil. São Paulo: Annablume, 2013.

Kuba, Leo; Cavalcanti Miguel. Man in Arena. Entrevista com Marcos Gomes. Disponível em https://www.youtube.com/watch?v=OjgJJiBeOu4. Acesso em 01.abr. 2016

Man in Arena. Entrevista com Gui Telles. Disponível em: https://youtu.be/2Cjx93XWgm0. Acesso em 02 abr. 2016.

- Man in Arena. Entrevista com por Samir Iásbeck. Disponível em: https://www.youtube.com/watch?v=wcBNz24T6Hk. Acesso em 03 abr. 2016. Man in Arena. Entrevista com Tallis Gomes. Disponível em: https://www.youtube.com/watch?v=qXIfJxoIZ1U. Acesso em 12 jun. 2016.

LATOUR, Bruno. Reagregando o social: uma introdução à Teoria do Ator-Rede. Tradução: Gilson César Cardoso de Sousa. Salvador/Bauru: Edufba/Edusc, 2012. Ciência em ação: Como seguir cientistas e engenheiros sociedade afora. Tradução: Ivone C. Benedetti. São Paulo: Editora UNESP, 2000. . To modernize or to ecologize? That's the question. In: Castree, N.; WillemsBraun, B. (orgs.). Remaking Reality: Nature at the Millenium. Londres /New York: Routledge, 1998.

LaZZARato, Maurizio e Negri, Antônio. Trabalho Imaterial: formas de vida e produção de subjetividades. $2^{\text {a }}$ Ed. Rio de Janeiro: Lamparina, 2013.

LEMOS, André. A comunicação das coisas: teoria ator-rede e cibercultura. São Paulo: Annablume, 2013.

LEVY, Pierre. A inteligência coletiva: por uma antropologia do ciberespaço. São Paulo: Edições Loyola, 1998. 
O que é o virtual? São Paulo: Editora 34, 1996.

As tecnologias da inteligência: o futuro do pensamento na era da informática.

São Paulo: Editora 34, 1993

L'HOTELLIER, Eduardo. Entrevista III [jan. 2016]. Entrevistador: Ana Patrícia Santana. São Paulo, 2016. Apêndice C

LOJKINE, J. A revolução informacional. São Paulo: Editora Cortez, 2002.

MORIN. Edgar. Introdução ao pensamento complexo. Porto Alegre: Sulina, 2007.

; LE MOINGNE, Jean. A inteligência da complexidade. São Paulo: Petrópolis, 2000.

NEGRI, Antônio. 5 lições sobre o império. Tradução: Alba Olmi. Rio de Janeiro: DP\&A, 2003. ; HARDT, Michael. Império e Multidão. Rio de Janeiro: Record, 2001 ; LAZZARATO, Maurizio. Trabalho Imaterial: formas de vida e produção de subjetividade. Rio de Janeiro: DP\&A, 2001

NeTO, Jorge. V. Entrevista VII [mar. 2016]. Entrevistador: Ana Patrícia Santana. São Paulo, 2016. Apêndice G.

NEWMAN, Mark E. J. The structure and function of complex networks. SIAM Review, SIAM, v. 45, n2, p. 167- 256, 2003. Acesso em Agosto de 2015.

Osterwalder, Alexander; Pigneur, Yves. Business Model Generation. Rio de Janeiro: Atlas Book, 2011.

Parente, André (Org.) Tramas da rede. Porto Alegre: Editora Sulina, 2013.

PORTAL ISTO É DINHEIRO. Websérie: como eu comecei. $4^{\circ}$ episódio. Entrevista com Tallis Gomes. Publicada em 16 Mai. 2014. Disponível em: http://www.istoedinheiro.com.br/videos/negocios/20140516/serie-como-comecei-tallisgomes-criador-easy-taxi/2597.shtml. Acesso em 02 maio. 2016. 
PORTAL EXAME. Startup cria série na web sobre dia a dia do negócio; veja. Publicado em: 25 ago. 2015. Disponível em: http://exame.abril.com.br/pme/noticias/startup-faz-videoscontando-como-e-ter-um-negocio-inovador. Acesso em 01 Jun. 2016

PRIPAS, Flávio. Entrevista I [jan. 2016]. Entrevistador: Ana Patrícia Santana. São Paulo, 2016. Apêndice A.

REVISTA-SE DE CONTEÚDO. Um minuto com Eduardo L'hotellier. Disponível em: https://www.youtube.com/watch?v=nqy8BrHVqZU. Acesso em: 01 Jul. 2016.

RIES, Eric. A startup enxuta: como os empreendedores atuais utilizam a inovação contínua para criar empresas extremamente bem-sucedidas: São Paulo: Leya, 2012.

RIFKIN, Jeremy. Sociedade com custo marginal zero: a internet das coisas, os bens comuns colaborativos e o eclipse do capitalismo. Tradução de: Monica Resemberg. São Paulo: M.Books, 2016

A terceira revolução industrial: como o poder lateral está transformando a energia, a economia e o mundo. Tradução de: Maria Lúcia Rosa. São Paulo: M. Books, 2012.

A era do acesso: a transição de mercados convencionais para networks e o nascimento de uma nova economia: São Paulo: Makron, 2005.

A economia do hidrogênio: a criação de uma nova fonte de energia e a redistribuição do poder na terra. São Paulo: M.Books, 2003.

RODRIGUES, Rose. Entrevista IV [mar. 2016]. Entrevistador: Ana Patrícia Santana. São Paulo, 2016. Apêndice D.

REDES DIGITAIS EMPREENDEDORAS. Fanpage. Disponível em: https://www.facebook.com/groups/367002150124699. Acesso em: 14 jun. 2016.

SEBRAE-SP. Pesquisa Lado A, Lado B - Startup 2015. Disponível em: http://www.sebraesp.com.br/arquivos site/biblioteca/EstudosPesquisas/estudos tematicos/lad o_A_B_startups.pdf. Acesso em: 01 jun. 2016. 
Inspirações. Entrevista: Eduardo L'Hotellier. Disponível em: https://www.youtube.com/watch?v=VTj5kB1lV1Y. Acesso em: 20 jun. 2016.

Inspirações. Entrevista: Tallis Gomes. Disponível em: https://www.youtube.com/watch?v=ydKk7P3d7LE. Acesso em 20 jun. 2016.

SEn, Amarthya. Desenvolvimento como liberdade. São Paulo: Companhia das Letras, 2000.

SHIRKY, Clay. A cultura da participação. A criatividade e generosidade no mundo conectado. São Paulo: Zahar, 2011.

SHAPIRO, Carl. \& VARIAN, Har. A economia da informação: Como os princípios econômicos se aplicam à era da internet. Rio de Janeiro: Elsevier, 2003.

SHIRAISHI, Samantha. Qual o papel da juventude no desenvolvimento economia criativa? Blog Social Good Brasil. Disponível em: http://socialgoodbrasil.org.br/2013/qual-o-papel-dajuventude-no-desenvolvimento-economia-criativa-ecosoc2013. Acesso em: 10 jun. 2016.

SPINOZA, Baruch. Ética . Tradutor: Tomaz Tadeu. São Paulo: Editora Autentica, 2016

STARTUP WEEKEND. Disponível em: http://startupweekend.org/. Acesso em 11 jun. 2016.

STARTUP BRASIL. Apresentação do programa Startup Brasil. Publicado em 4 jun. 2014. Disponível em: http://pt.slideshare.net/flaviosmarinho/slides-sobre-programa-startup-brasilmcti. Acesso em: Acesso em 01 jun. 2016

$\begin{array}{llll}\text { STARTUP NAVE. } & \text { Disponível }\end{array}$ http://www.estacio.br/solucoescorporativas/link360/ed1214/materia-inovar.html. Acesso em 01. Jun. 2016

TAPSCOTT, Don. Economia digital: promessa e perigo na era da inteligencia em rede.São Paulo: Makron, 2007.

WILliams, Anthony D. Wikinomics. Como a colaboração de massa pode mudar o seu negócio. São Paulo: Nova Fronteira , 2007. 
Macrowikinomics: reiniciando os negócios e o mundo. Rio de Jneiro:

Elsevier, 2011.

TAROZZI, Massimiliano. O que é a Grounded Theory? Tradução: Carmem Lussi. Petrópolis: Vozes , 2011.

SANTOS Milton. Por uma outra globalização: do pensamento único à consciência univeral. Rio de Janeiro: Editora Record, 2000.

SCHAFF, Adam. Sociedade informática : as consequiências sociais da segunda revolução industrial. 4a ed. Trad. Carlos Eduardo Jordão Machado e Luiz Arturo Obojes. São Paulo: Brasiliense, 1995

SCHUMPETER, Joseph A. A teoria do desenvolvimento econômico. São Paulo: Abril Cultural, 1982.

Slack, Nigel; Chambers, Stuart; Johnston, Robert. Administração da produção. $2^{\mathrm{a}}$ Ed. São Paulo: Atlas, 2002

Shane, Scoott. A General Theory of Entrepreneurship: The individual-Opportunity Nexus. Edward Elgar Pub, 2004 Venkataraman, Sankaran. (2000) The Promise of Entrepreneurship as a Field of Research. Academy of Management Review 25(1): 217-26.

UP GLOBAL. Fostering a Startup and Innovation Ecosystem. São Paulo, 2014. Disponível em: http://pt.slideshare.net/cuevasm1/fostering-a-startup-and-innovation-ecosystem. Acesso em 19 mar. 2016.

ULRICH, Fernando. Bitcoin: A moeda na era digital. São Paulo: Instituto Ludwig Von Mises Brasil, 2014.

Werkema, Cristina. Criando a Cultura Lean Seis Sigma. 3. ed. Rio de Janeiro: Elsevier, 2012. 
WEST, Douglas B. Introduction to graph Theory. $2^{a}$ edição. New Jersey: Prentice Hall, 2001

Wow ACEleradora DE Startups. Publicado em 14 jan. 2014. Disponível em: https://www.youtube.com/watch?v=9H79ygNZHK0. Acesso em: 16 jun. 2016.

ZoGBI, Paula. Gráfico mostra explosão impressionante no número de unicórnios mundialmente. Portal starse. Publicado em 8 jan. 2016. Disponível: http://startse.infomoney.com.br/portal/2016/01/08/16008/grfico-mostra-explosoimpressionante-no-nmero-de-unicrnios-mundialmente/. Acesso em 13. Abr. 2016.

VENKOTORAMON, Sankaran- 1997. The distinctive domain of entrepreneurship research: An editor's perspective. In J. Katz \& R. Brockhaus (Eds.), Advances in entrepreneurship, firm ernergence, and growth, vol. 3: 119- 138. Greenwich, CT: JAI Press.

VUlKan, Nir. The economics of E-Commerce: A strategic guide to understanding and designing the online marketplace. Princeton University Press, 2003 


\section{APÊNDICE A \\ TRANSCRIÇÃO DE ENTREVISTA INTENSIVA I}

\begin{tabular}{ll}
\hline ENTREVISTADO: & $\begin{array}{l}\text { Flávio Pripas, diretor executivo do espaço Cubo Co-working, } \\
\text { fundador da Startup de moda Fashion.me e da startup administradora } \\
\text { de bitcoins Bitinvest (descontinuada). }\end{array}$ \\
\hline LOCAL: & Cubo Co-working, São Paulo, SP \\
\hline DATA & Jan 2016 \\
\hline
\end{tabular}

P. 01 O que é uma startup?

R. 01 Eu entendo que startup é um empresa de base tecnológica em busca de um modelo de negócio altamente escalável. O que significa um modelo de negócio altamente escalável?

É um modelo de negócio que pode impactar a vida de muitas pessoas. Por que de base tecnológica? Porque a única forma de você impactar a vida de muitas pessoas é tendo tecnologia por trás. Por que em busca de um modelo de negócio? Porque está tentando fazer algo que não foi feito ainda.

P.02 Então ela precisa ter uma inovação?

R.02 A inovação é a busca do modelo de negócio. Ela precisa ser escalável. Porque, por exemplo, uma inovação, mas uma inovação só para atender esta cadeira que estamos sentados, para mim não é uma startup. Agora se for mudar o modo de sentarmos em todas as cadeiras do mundo, no meu ponto de vista é uma startup.

P.03 A tecnologia define a startup?

P.03 No meu mundo sim, se você falar com o SEBRAE, não. Para o SEBRAE a startup é qualquer empesa iniciante. E ainda na minha concepção, startup é o que a gente chama de empresa de alto impacto que é uma empresa que vai impactar a vida de muitas pessoas.

P.04 Qual a natureza deste impacto?

R.04 Impactar a vida de muitas pessoas. Hoje em dia muita gente está chamando taxi via aplicativo e ninguém está estendendo a mão na rua. Isso é startup. Definições você tem das mais diversas. Cada um enxerga de uma maneira diferente. $\mathrm{O}$ contexto que a gente tenta colocar aqui no Cubo é base tecnológica. Vamos tentar qualificar algumas variáveis: base tecnológica, 
teste de modelo de negócio inovador, alto impacto e alta escala em busca de tudo isso. É uma empresa que não está lá ainda. Porque quando estiver lá, já não é uma startup, é uma empresa.

P.05 Então o Uber, por exemplo, você considera uma startup?

R.05 Sim. O Uber na verdade está mudando o mundo, está na verdade desafiando o status quo. Ela tem um risco regulatório enorme em todos os países em que ela está atuando. Ela não é um modelo de negócio comprovado. E, assim, quando o Uber for onipresente e massificado não vai ser mais startup, mas hoje ele é. Aqui em São Paulo teoricamente o Uber é proibido. Eu uso todo dia, mas em teoria é proibido. Isso pra mim é a definição de startup. Fazendo uma coisa proibida. Que todo mundo sabe que está certo, tem várias “discussões”, várias discussões se está certo ou se está errado não sei o que, mas que está mudando a vida das pessoas. Estão oferecendo um serviço de altíssima qualidade comparado com os serviços já existentes.

P.06 De certa forma esta possibilidade de fazer este teste do modelo muito próximo com o usuário final é uma particularidade do empreendedorismo startup?

R.06 Nenhum teste resiste ao usuário final. Nenhuma teoria resiste ao usuário final.

P.07. Então os modelos de empreendedorismo startup eliminam o estágio de incubação tão presente nos modelos de negócios tradicionais ou as chamadas aceleradoras de startups substituem este estágio de experimentação do plano de negócio, hoje chamado de modelo de negócio?

R.07 Plano de negócio está errado desde o momento que você aperta o salvar. Porque há alguns anos as startups são empresas que precisam provar o seu modelo de negócio muito rápido e esta prova do modelo de negócio é feita através de experimentação. Se você observar, é o que acontece no laboratório. Você vai experimentando, experimentando e $99 \%$ dá errado e 1\% dá certo. É este $1 \%$ que gera a inovação. A startup faz isso. Faz isso com o cliente final de cara. A startup, ao invés de ficar perdendo tempo fazendo plano de negócio, ela vai para rua e conversa com seu cliente. Todas as empresas que estão aqui no Cubo fazem isso. O plano de negócio das empresas daqui pode ser um PowerPoint com dez slides com uma planilha de Excel e não precisa mais que isso, apresentando: essas são as hipóteses que eu vou testar; é desta maneira que eu vou testando; é neste prazo que eu vou ver se este teste deu certo ou deu errado; vai custar tanto para fazer este teste. 
P.08 E com relação aos atores, quem são esses empreendedores startup? Me parece que tem uma grande diversidade também. Por que antes era algo muito mais relacionado ao acesso ao capital e hoje talvez tenha este maior acesso à atividade. O que você pensa?

R.08 Hoje é muito fácil fazer as coisas, na verdade. Quando a gente fala de uma startup de tecnologia e de tecnologia digital, que você não precisa de hardware, basta você ter um programador para fazer qualquer coisa, qualquer produto e serviço digital. Então, assim, o custo é zero. Quando você tem uma coisa que custa zero e pode mudar o mundo, você começa a entrar neste processo que estamos vivendo nos últimos dez, quinze anos, em que o mundo mudou completamente. Há vinte anos não existia e-mail, tá?. Então assim, foi muito intenso. Hoje em dia custa zero criar um "Instagram" da vida para ser vendido por um bilhão de dólares dois anos depois.

P.09 Então dizer que startup é um modelo de negócio ou uma cultura estaria errado?

R.09 Você dizer que startup é um modelo de negócio, acho que você estaria errada. Dizer que é uma cultura é diminuir tudo. Startup é muito mais que um modelo de negócio, startup tem um viés cultural, porque para você ser startup você tem que desafiar status quo. Isso é o viés cultural, mas não é que startup seja uma cultura. Eu tenho que elaborar mais para explicar, mas me parece que é muito mais.

P.10. Do que é composto o ecossistema de startup?

R.10. É composto por todos os agentes do ecossistema. É todo o ambiente de negócio para fazer a startup prosperar. Ou seja, é desde o empreendedor, universidade, investidores em todas as etapas, governo, entidades de apoio, são eventos, encontros, Cubo, é tudo. É muito subjetivo, acaba sendo uma síntese de tudo. E tem coisa que não é só entidade que você consegue identificar, para mim o ecossistema de startup tem coisas que não são tangíveis. Você ter esse ciclo de criação de empresa, investimento, desinvestimentos, é o saudável para que o ecossistema exista. Então é tudo ao mesmo tempo.

P.11 E nesta dinâmica apresentada pelo ecossistema, os processos colaborativos de fato existem?

R.11 Sim, este ambiente é completamente colaborativo. Todo mundo compartilha tudo com todo mundo para fazer as coisas acontecerem. Já me perguntaram: como funciona a propriedade intelectual do Cubo? Não funciona e estamos zero preocupados com isso. Você entra neste espaço físico, você tem que entrar aqui para colaborar, para compartilhar, porque da 
colaboração e do compartilhamento todo mundo ganha. Aqui durante todo o dia você ouve uma série de conversas paralelas que são conversas colaborativas.

P.12 Como funciona a disponibilização de espaços para essas startups no Cubo?

R.12 Temos 250 mil pessoas, mais ou menos 50 empresas, temos já 40 empresas aqui, mais ou menos 210 pessoas. Todas as startups que foram selecionadas por indicação e elas pagam para trabalhar aqui dentro. Por que que elas estão interessadas em serem selecionadas e pagarem para trabalhar neste espaço? Por causa do ambiente colaborativo que estamos criando. Por causa da lacuna de mercado que estamos preenchendo que é este ponto de encontro de empreendedor com empreendedor, empreendedor com universidade, empreendedor com investidor, empreendedor com grande empresa. Então isso cria muito valor naturalmente no ecossistema de startup.

P.13 Como é o processo de seleção?

R.13 Conversa comigo e eu vejo se faz sentido. Deixe-me qualificar o que é fazer sentido. As empresas aqui têm que ser de base tecnológica, este é um critério que eu olho, vejo se o empreendedor não é um empreendedor esquizofrênico, o que acontece muito no Brasil. Vou explicar o que é um empreendedor esquizofrênico. Empreendedor que quer fazer dez coisas ao mesmo tempo e não faz nenhuma das dez direito. Vejo se ele está resolvendo um problema real de um mundo real e vejo se a empresa tem potencial de atingir alta escala. Passando por este filtro e conversado (inaudível) a empresa vem pra cá. Completamente subjetivo e a gente quer que seja assim. Por que as pessoas confiam e querem que eu faça este primeiro filtro? Porque eu estou neste mundo desde 2008. Então já vi muita coisa e já falei com muitas pessoas. Ganhei uma certa credibilidade no mercado.

P.14 Você vem do mercado financeiro?

R14 Sim, até 2008, depois eu virei empreendedor.

P.15 E o pensamento cartesiano?

R.15 Total. Zero colaborativo. Mas minha trajetória é assim: eu comecei em uma empresa brasileira que foi comprada por uma empresa americana que foi comprada por um banco. Sempre trabalhei com tecnologia. Quando a empresa americana foi comprada pelo banco fui convidado para assumir a área de tecnologia e depois de outra mudança fui convidado para ir para fora, ajudar na reformulação da área de tecnologia. Isso foi em 2008, no auge da crise do 
mercado financeiro. Fiz um site de brincadeira para minha esposa porque eu sou programador, não sou desenvolvedor que é muito chique. $\mathrm{O}$ site cresceu com zero de investimento, tinha 30 mil acessos por dia. E como o mercado financeiro naquela época estava no caos por causa da crise no mercado, eu disse: Ah! Vou ver se isso dá em alguma coisa e vou ficar seis meses nisso, então pedi minhas contas. E desta decisão acabei entrando neste mundo e neste mundo eu aprendi que só dá para crescer se compartilhar as coisas.

\section{P.16 Conexão?}

R.16 Sim conexões. E eu segui uma escola de pensamento empreendedor que se chama effectuation, termo cunhado por Sarasvathy, que é super bacana e virou minha filosofia de vida. Tudo o que eu faço desde 2008 eu sigo os pilares da effectuation. São cinco, mas eu gosto de resumir em quatro, que fica mais fácil. A única variável que o empreendedor tem controle são as perdas suportáveis, ou seja, até onde ele vai se tudo der errado. Porque o sucesso você não controla, nem o fracasso. A única variável que você controla são as perdas que você suporta se tudo der errado. Daí as outras variáveis do effectuiation: futuro imprevisível, como o futuro é imprevisível, vai testar possibilidades através de parcerias. Esta virou minha filosofia de vida e é o que faço hoje. E está sendo legal até agora!

P.17 Tudo a ver com o espaço Cubo, não é?

R.17 Sim, tudo a ver com o espaço e é a filosofia que nós conversamos com as pessoas aqui dentro. O empreendedor aqui é selecionado. Ele paga para trabalhar aqui. E de acordo com o nosso contrato, a cada seis meses nós podemos mandar ele ir embora. Por que? Porque startup ou ela pode dar certo ou ela pode dar errado. Se ela estiver fazendo "voo de galinha", que significa nem dando certo, nem dando errado, ela vai embora.

P.18 Então você acha que seis meses já dá para fazer esta avaliação?

R.18 Tenho certeza que não. Acho que para saber se uma startup está dando certo ou está dando errado, é preciso mais tempo. Seis, doze ou dezoito meses, mas a gente colocou no contrato a cada seis meses porque deve ter casos que provavelmente vai dar para ver. Não sei. Eu te respondo daqui a seis meses. A gente só está aberto há dois meses e duas semanas. Depois eu vou te responder melhor esta pergunta. Tudo que a gente está fazendo aqui é laboratório. Nada é verdade absoluta.

P.19 Qual a relação de vocês com as grandes empresas? 
R.19 Grandes empresas não sabem trabalhar com startups. E não sabem trabalhar com pequenas empresas. O Itaú está fazendo isso, a Ambev, a Accenture e a Cisco para saber o que está ocorrendo no mercado, para tentar mudar o processo interno e decidir como elas vão atuar com as startups.

P.20 Por que um espaço coworking para startups?

R.20 Existem estudos que apontam a densidade como um dos fatores chaves de ter um ecossistema de startup de tecnologia que floresça. E todos eles falam que o contato físico, o olho no olho é muito importante. É quando você cria densidade de pessoas, de ideias e de oportunidades que não seriam geradas se você não estivesse em um local como esse.

P.21 Então elas estão fazendo laboratório também?

R.21 Radar e laboratório. O Cubo é uma associação sem fins lucrativos de fomento. Assim, qual a agenda privada de grandes empresas apoiarem o Cubo? Olhar o campo deste mercado. As grandes empresas estão preocupadas e elas não têm a velocidade que as startups têm. Então, apoiando uma iniciativa como essa, elas sabem o que está acontecendo neste mundo das startups e podem tentar se antecipar, comprar alguém, investir em alguém, tentar fazer alguma coisa a respeito para não perder o timing.

P.22 Por que as startups têm esta velocidade que as outras empresas não têm? Seria a estrutura, o tipo de trabalho com a tecnologia?

R.22 A startup tem uma hipótese e ela testa a hipótese, custe o que custar. Vamos voltar ao exemplo do Uber. Ele é proibido? Não importa, se achamos que vamos entregar um produto melhor para as pessoas, a gente acha que vai mudar a vida das pessoas, então vamos fazer mesmo assim. Uma grande empresa não pode fazer isso porque tem a reputação, tem responsabilidade social com seus funcionários, tem processo interno. Startup não tem nada disso, ela está lá para provar seu ponto, para provar sua hipótese, para mudar o mundo. Então é aquele negócio que agora virou chavão, né? Que o pessoal do Facebook fala “move fast and break things."

P.23 Sim, mas a startup trabalha com a questão da reputação, não?

R.23 Lógico que elas se preocupam. Todas as startups aqui estão fazendo coisas para mudar o mundo. Mas, por exemplo, uma coisa que muitas startups não se preocupam é se ela está colocando o dedo na ferida de alguém por estar fazendo um produto melhor. Então o Uber não 
se preocupa que ele está colocando o dedo na ferida da associação de taxi que cobra propina para dar ponto na rua. Não importa isso, só que tem muita gente no mercado que se preocupa. Uma empresa, por exemplo, que está entregando empréstimo mais barato, não está preocupada se ela está incomodando os bancos enquanto os bancos lucram, ela está fazendo do mesmo jeito. Então, reputação talvez não seja a palavra correta, por ser um negócio importante. O mundo das startups, como é um mundo muito pequeno, a reputação é importante. Deixe-me tentar mudar as palavras. Integridade e reputação são coisas que as pessoas têm que ter. Têm que fazer as coisas corretas. Têm que deixar o mundo ir para frente, o mundo ficar mais bonito, ficar melhor. Só que quando eu disse antes de "se preocupar" com a reputação eu quis dizer: não se preocupe em desafiar o status quo. Foi isso que eu quis dizer para explicar melhor. Então assim, o status quo não é bom. O mundo tem que ir para frente. Se a gente fosse acostumado com o status quo a gente viveria nas cavernas e caçando, sem agricultura. Então tem que desafiar isso.

P.24 As startups como Uber e 99taxi são entendidas como construtoras de interfaces. O que pensa deste argumento? Você acha que isso é reduzir demais?

P.24 Não. Eu concordo. Elas são construtoras de interfaces.

P.25 Então na verdade o que as startups, em grande medida, fazem é construção de processos comunicativos?

R.25 Não dá para generalizar, na verdade. Você usou dois exemplos que são construtoras de interfaces na verdade, o Uber, 99taxi, Airbnb. Todas as startups ou de economia colaborativa, que é que está se chamando hoje, ou então marketing place, ou então de plataformas que encurtam distancias entre fornecedores e clientes, são construtoras de interfaces. Só que a gente tem muitos exemplos de startups que são construtoras de plataformas. Eu tenho uma startup aqui que é uma plataforma que aumenta a eficiência de escritórios de advocacia. Isso não é uma construtora de interfaces. Mas ela está mudando o mundo porque o escritório de advocacia hoje ganha dinheiro fazendo copy and paste em documentos. Isso custa muito caro. Ela quer mudar este jogo de forças. Não é interface. É o produto, é o serviço. Então não dá para generalizar.

P.26 Tem sempre que ter na equipe alguém que conheça com peculiaridade o problema identificado?

R.26 Não necessariamente. Eu fui dono do maior site de moda do Brasil de 2009 a 2013 , não entendo nada do assunto e não gosto do assunto. Eu acho assim, quando estamos falando de tecnologia, tem sim que ter alguém, um cara bom de tecnologia. O Mark Zuckerberg fundador 
do Facebook não é o maior antropólogo do mundo, não conhece relacionamentos sociais, ele não sabe como a população tem que se relacionar para deixar o mundo mais justo. E ele está fazendo isso. Então, assim, conhecimento técnico hoje quando a gente fala de tecnologia é mais importante do que o domínio do negócio. Se tiver os dois, perfeito. O Paulo Veras, fundador da 99taxi que falamos antes. Ele nunca dirigiu um taxi na vida.

P.27 Ele apenas identificou uma oportunidade?

R.27 Ele copiou uma oportunidade e fez melhor. Copiou a ideia do Easy taxi, referindo-me à parte de pagamento. Mas a tecnologia, sim, tem que ter o domínio de tecnologia. Nenhuma startup aqui se não tiver um sócio de tecnologia vai dar certo. Eu não selecionei nenhuma startup que não tivesse um cara de tecnologia.

P.29 E o design?

R.29 Hoje é muito importante.

P.30 É a linguagem da startup?

R.30 É. O design é a linguagem da startup. Só que a tecnologia vive sem o designer e o designer vive sem a tecnologia.

P.31 São independentes?

R.31 Acho que quando você junta, um mais um é maior que dois. Mas convivem sozinhas. Eu acredito nisso depois de conversar com muitas pessoas durante muitos anos. Mas eu concordo com você. Design é a linguagem deste mundo. 


\section{APÊNDICE B \\ TRANSCRIÇÃO DE ENTREVISTA INTENSIVA II}

\begin{tabular}{ll}
\hline ENTREVISTADO: & $\begin{array}{l}\text { Eduardo L'Hotellier, fundador e CEO da plataforma de serviços } \\
\text { GetNinjas }\end{array}$ \\
\hline LOCAL: & São Paulo, SP \\
\hline DATA & Jan 2016 \\
\hline
\end{tabular}

P.01 Por que empreender no digital?

R.01 Eu trabalhava em uma grande empresa de investimentos, tenho formação em Engenharia da Computação e formação em Administração, então fazia todo sentido eu empreender no digital. É algo que eu já conhecia. Outra coisa que me incentivou no começo foi o custo para abrir um negócio, o custo para criar um protótipo. É muito caro criar uma empresa gigante em tecnologia, é muito investimento em tecnologia, é muito investimento em marketing, mas em contrapartida é muito barato criar um produto mínimo viável, que é um protótipo no digital. Criar um protótipo de uma loja no físico é muito mais caro. Você tem o aluguel do espaço, o layout da loja, você tem suas peças, você tem seus estoques. Então imagina criar uma loja física no shopping, um quiosque que venda algum produto ou serviço. Ele é muito mais caro do que criar uma página ou um aplicativo e provar se aquele negócio tem adesão ou não. Então no meu caso foi uma questão econômica e também uma questão de aptidão, por conta da minha formação.

P.02 A GetNinjas é frequentemente lembrada como um caso de sucesso do empreendedorismo startup, embora a definição deste tipo de empreendedorismo ainda seja bastante diversa. Eu tenho ouvido ao lONGo da pesquisa uma tendência a considerar a tecnologia como algo que de certa forma define a startup. O que você entende por empreendedorismo startup?

R.02 A startup é uma empresa que está buscando o seu modelo de negócio. É mais comum ouvir na mídia startup de tecnologia, mas uma empresa de bioquímica que está desenvolvendo uma droga é uma startup, uma empresa que está desenvolvendo um novo modelo de franquia é uma startup. É mais uma questão que a gente escuta mais porque a mídia fala mais de produtos tecnológicos porque são produtos que em geral atingem mais pessoas e despertam mais a 
curiosidade dos leitores. A Startup é uma empresa iniciante que está começando a empreender, então pode ser até nos mercados tradicionais.

P.03 Você não acha que o fato de vocês estarem trabalhando com a tecnologia dá ao seu negócio uma escalabilidade que talvez uma empresa tradicional não teria?

R.03 Por isso que tem mais clientes e roubamos o termo startup.

P.04 Roubaram?

R.04 Porque não necessariamente precisa ser tecnologia da informação. Pode ser uma tecnologia médica, robótica ou mercados tradicionais. Pode ser um novo perfume, uma nova fragrância é uma startup. Então, é mais porque roubam o termo pelo uso repetitivo e pelas escalas dos produtos de tecnologia que são maiores

P.05 E quanto à necessidade da startup de escalar rápido?

R.05 Não existe uma necessidade de uma startup escalar rápido. Existem maneiras diferentes de iniciar uma startup. Uma startup que é fundada pelo próprio empreendedor tem uma exigência de crescimento diferente de uma startup que um fundo coloca uma grana porque ele quer ter um retorno sobre o investimento de 30\%, $40 \%$ anual no seu portfólio, então ele quer que a empresa cresça muito rápido para pagar pelas empresas que não cresceram. Então se ele está fazendo um financiamento station finance que é financiamento por estágio, financiamento de capital, você tem uma exigência de crescimento bem diferente de um startfound que é um strap onde você cresce com sua receita. Então, não existe uma necessidade de uma startup crescer rápido. Existe uma necessidade das startups que são financiadas pela metodologia de pensamento por estágio de crescerem rápido porque seus investidores precisam deste crescimento para dar retorno aos seu fundo, ao mercado acionário ... Então não é inerente à startup, é inerente ao modelo de crescimento. E isso mais uma vez é roubado, porque startups finance crescem mais rápido e também explodem mais rápido, saem mais na mídia e rouba o termo startup, roubam o conceito startup para si.

P.06 O protótipo da plataforma hoje chamada GetNinjas foi testado em 2010. Você já chegou ao seu modelo ideal de negócio?

R.06 Ainda existe um processo. Estamos alterando um modelo cultural, mudando a maneira das pessoas contratarem serviços. Nós estamos propondo a contratação de um porteiro via 
aplicativo. A gente ainda está riscando os perfis de mercado. O que a gente tem hoje não é o que seremos daqui a cinco anos. A gente tem um caminho para tornar as coisas mais fáceis agora. Como vai ser? Não sei...

P.07 Mudando maneiras de fazer as coisas. As startups operam desafiando o status quo? É uma consequência ou uma intenção?

R.07 Isso é uma consequência, porque eu acho que você cria, você coloca muito dinheiro em um mercado novo. É mais fácil construir uma média empresa em um mercado que já existe. Se você abre hoje um restaurante você vai conseguir clientes mas é muito difícil atingir um bilhão. É muito difícil criar uma nova rede de restaurantes. Agora em mercados que não existem, você criar este mercado e você crescer é muito mais difícil, existem muito mais falhas. A cada 100, 99 falham, mas uma consegue e domina. Então acaba sendo uma consequência de empresas que desafiam o status quo porque se não desafiasse ela teria o seu crescimento capado pelos competidores. Fazer uma coisa que todo mundo já faz, você consegue crescer, mas não consegue ser um gigante. A intenção não é quebrar o status quo, a intenção é criar um modelo de negócio que seja viável, escalável.

P.08 A sua experiência prévia em consultoria estratégica te ajuda no que você faz hoje à frente da GetNinjas?

R.08 Ajuda na tratativa com investidores. Ajuda a pegar este problema e dividir em pequenas partes. O trabalho com consultoria estratégica é a interpretação de dados e aconselhamento das empresas. Na startup obviamente você tem menos dados e ciclos mais rápidos, mas todo ferramental lógico e comunicação da consultoria estratégica usa-se muito.

P.09 E o corpo social da empresa?

R.09 São 70 pessoas no total.

P.10 Você tem os processos desenhados?

R.10 Tínhamos 30 pessoas ano passado. Este ano temos 70 pessoas. Em uma empresa em ritmo acelerado de crescimento, os processos são muito mais flexíveis que em uma empresa consolidada.

P.11 O que de certa forma nos interessou trazer a GetNinjas como case na pesquisa juntamente com alguns outros é que me parece que talvez exista um nível de facilidade maior quando você 
trabalha com criação de interfaces. Então você pega, por exemplo, os aplicativos de transporte individual de passageiros, onde de certa forma acaba sendo uma interface que vai conectar passageiro a motorista e que também oferecerá facilidades com os meios de pagamento. Me parece que GetNinjas tem um nível de complexidade maior porque é diferente a relação que eu tenho com um aplicativo desses na condição de usuário, onde eu vou pedir um taxi ali que vai utilizar a tecnologia GPS do meu celular, onde eu saio de uma via pública para outra via pública e pronto. Então a relação é muito instantânea. E no caso de vocês contratar uma pessoa para um serviço em sua casa, existe aí uma parte do processo que é online mas existe uma parte do processo que é offline. E como é que o usuário percebe vocês fazendo esta intermediação, como eles atribuem responsabilidades, de repente um serviço não sai como ele pretendia ou se ele tem uma expectativa, ou talvez ele tenha que ver este profissional mais de uma vez? Diferente de um taxi que eu posso simplesmente fazer ali uma avaliação que não foi positiva ou rejeitar aquele motorista numa próxima corrida. Diferentemente de um profissional que eu trago para minha casa ou um professor de inglês que eu contrato. Existe aí um fator continuado de confiança e relacionamento que talvez quando você funciona apenas como uma interface você não tenha que se preocupar...

R.11 Parte do processo é offline, então eu tinha que prover algumas informações como antecedente criminal, certificação profissional. Mas nós funcionamos como um classificado. Nosso modo de funcionamento é um classificado onde o usuário encontra o serviço e a responsabilidade é do usuário fazendo a contratação.

P.12 De que maneira é monetizado?

R.12 O profissional paga uma assinatura. Ele paga para receber 30 clientes por mês. Ele paga por conexões.

P.13 Plataforma ou aplicativo. Qual dá mais fluxo?

R.13 Site responsivo. O mobile site. O cara busca no Google e entra no site pelo celular. 


\section{APÊNDICE C TRANSCRIÇÃO DE ENTREVISTA INTENSIVA III}

\begin{tabular}{ll}
\hline ENTREVISTADO: & Ricardo Kaudoaki, gerente comercial na plataforma Prosas \\
\hline LOCAL: & São Paulo, SP \\
\hline DATA & Jan 2016 \\
\hline
\end{tabular}

P.01 Quais as suas experiências anteriores ou em paralelo à prática do empreendedorismo?

R.01 O Prosas tem um viés muito social, então eu acho que para as pessoas trabalharem no Prosas... enfim... tem muito empreendedor social aí no mercado que é gente que está insatisfeito com a carreira e quer mudar e quer fazer o bem, vai ... e vem com um conceito digamos, antiquado ou inadequado, não sei. O setor social é um setor que precisa de profissionalização, precisa de gente que tem experiência no assunto, que conhece as dificuldades, sabe como funciona o setor por dentro, as ONGs, as empresas, etc. Acho que isso é importante. O currículo de todo mundo aqui, inclusive o meu, é focado na área social.

P.02 Como empreender se apresentou para você como uma possibilidade? Quais as suas experiências até chegar à startup Prosas?

R.02 Então, qual é a minha história? Eu sou formado em Administração Pública, pela FGV e sou mestre em Políticas Públicas. Trabalhei em diversos tipos de organizações focadas na causa pública. A minha área é muito em tecnologia e sociedade, que é a forma como a tecnologia impacta no comportamento social ou entender como a tecnologia e propor tecnologias para melhorar a condição social das pessoas. Então neste sentido eu já trabalhei no governo de São Paulo. Eu era gerente de informações e tocava um projeto chamado Rede Sim. Logo no início de 2008, as redes sociais estavam começando a bombar neste ano e as instituições, elas estavam percebendo que poderiam usar as redes sociais para chegar no cidadão, para chegar na sociedade. Nesta época o José Serra começou a usar o seu Twitter pessoal como ferramenta para se comunicar com as pessoas, dando baile em jornal e assessoria de comunicação, era ele com todo mundo. E começou um sucesso relevante e as pessoas começaram a entender que as tecnologias poderiam ter uma função pública. Nesta época eu gerenciava um projeto super inovador para a época, onde a gente usava tecnologias e redes sociais para se comunicar com o nosso público. No caso o projeto que eu trabalhava se chamava CEPAM, que era um órgão responsável pelo relacionamento com os municípios e o nosso trabalho com a Rede Sim era 
fazer com que os funcionários públicos municipais conversassem entre si usando as ferramentas de internet. Hoje é uma coisa obvia, básica, mas na época era muito interessante, nós criamos um monte de coisas, como wiki de conselhos municipais e wiki de pareceres jurídicos relacionados à gestão municipal.

Depois do estado de São Paulo eu fui para o estado de Minas e lá eu toquei três projetos relacionados às tecnologias e sociedade. Um muito focado na construção coletiva de políticas públicas pelo Governo de Minas. Então o estado queria se aproximar da sociedade na construção de políticas públicas usando tecnologias. O projeto se chamava Movimento Minas. Então a ideia era que o cidadão oferecesse ideias para resolver determinados tipos de desafios mineiros. O Governo de Minas prototipava essas ideias para ver se elas funcionavam, para que de fato elas virassem uma política pública. Era uma proposta meio arrojada para a época. Isto em 2011.

\section{P.03 Fazer rede é muito difícil?}

R.03 Sim, nós tínhamos como objetivo também fazer com que as pessoas entendessem melhor as dificuldades do governo e vice- versa. O governo é uma máquina gigantesca com milhões de interesses, milhões de pessoas, milhões de tudo. Assim, as vezes coisas que surgem na rede não são de interesse de determinados atores do governo, então era um projeto extremamente difícil. Durante o andamento do projeto, a gente foi reduzindo o escopo, então a gente continuou usando tecnologias para se relacionar com os cidadãos, mas de outras formas. Por exemplo, fomos um dos primeiros governos a oferecer Twitecam do governador com a população. Desta forma, nós ficávamos testando formas de a tecnologia impactar na discussão política.

Depois do Movimento Minas, eu continuei trabalhando em Minas com uma parceria com o MIT Media Lab que é um dos maiores laboratórios de inovação do mundo. É um centro de pesquisas e estudo, mas assim, altamente disruptivo. Quando você pensa em inovação disruptiva você pensa em MIT Media Labs. Minas fez uma parceria com eles e eu gerenciei esta parceria. Nossa ideia era trazer os pesquisadores que estavam com ideias malucas para testá-las em Minas. Para aumentar a nossa chance, fazendo com que eles tivessem contato com o ecossistema de inovação mineiro e fazer com que as pesquisas tivessem a possibilidade de continuar em Minas. Enfim, bagunçar o negócio. Ai eu trouxe 12 pesquisadores do MIT Média Lab, principalmente voltados para a área de tecnologias cívicas, que é o que eu curto e o que a gente queria. E foram dois anos de loucura total. Pensar fora da caixa completamente. Eles trouxeram um projeto que era também fazer com que o cidadão mostrasse ao governo pelo 
celular quais eram os seus principais problemas e desafios, comparar as promessas dos políticos com o que de fato estavam acontecendo nas ruas ...

P.04 Então você sempre foi um empreendedor.

R.04 Acho que sim. Tudo isso eu fiz enquanto funcionário público, não de carreira, ou seja, não concursado, que eu acho que é super importante o governo ter para oxigenar a máquina, mas que muitos deles são usados com conotação partidária, mas nem todos. Eu fui um deles.

P.05 Então você começou este exercício de empreender testando o potencial das tecnologias digitais muito antes deste boom do empreendedorismo de startup tecnológica que vivemos ultimamente? Você falou 2008?

R.05 Acho que sim. Eu venho trabalhando nisso há um tempo. Em 1999 eu fui co-fundador de uma ONG que ensinava informática para pessoas de baixa renda e nós tínhamos também um programa de levar essas pessoas para fazer o que chamávamos de estágio cidadão em alguma ONG, utilizando o que aprenderam, como: ajudar pessoas de abrigos a fazer currículo ou ajudar velhinhos no hospital a fazer buscas na internet. Isso em 1999-2000. Eu ia muito na vibe de "fazer o bem e ajudar os pobres". Aí no decorrer da vida o negócio foi se sofisticando. Os conceitos foram se aprimorando, no sentido de entender melhor o que era isso e tentar propor soluções mais consistentes.

Eu também trabalhei em uma ONG chamada ITS, no Rio de Janeiro. Eu gerenciei um projeto chamado Plataforma Brasil, que também é um projeto de co-construção de políticas públicas, mas neste caso sem o estado envolvido. As pessoas quando estão discutindo políticas públicas e vêem que o Estado está envolvido, elas estranhamente ficam desconfiadas. Não deveriam ficar, uma vez que o estado é um dos principais atores na elaboração de políticas públicas. Era similar aos projetos de Minas, mas com a participação das pessoas completamente diferente. Muito mais participativa, muito mais propositiva, não era comentário do jornal, do Estadão, Uol. Lá a discussão era altamente qualificada. Era algo maravilhoso ver aquilo acontecer. E acontecendo pelas tecnologias.

Eu já fui consultor de responsabilidade social e já trabalhei no Centro de Ensino Terceiro Setor da FGV. Digamos assim, eu tenho um bom trânsito na área social, considerando governos, ONGs, consultorias ...

P.06 Então criar a Plataforma Prosas foi meio que uma consequência do seu histórico?

R.06 Sim. Foi um pouco... 
P.07 Por que a gente percebe que existe muita gente embarcando nas oportunidades de um ecossistema favorável ao empreendedorismo? Muitas vezes saindo de uma outra atividade que não tem uma relação direta com a que se pretende explorar, mas me parece que, pelo histórico apresentado, você está o tempo inteiro empreendendo...

R.07 Sim, mas no caso do Prosas eu não fui o criador, eu sou parte da equipe. Os criadores são o Bruno e o Thiago. Mas, enfim, eu acompanhei de perto a criação e agora contribuo...

P.08 Por que você acreditou nesta ideia?

R.08 Por ser uma ideia muito consistente. Pelo que eu conheço do setor social, tem muito "oba oba", tem muito picareta. Tem muita gente mal intencionada e tem muita gente bem intencionada e que faz as coisas mal feitas. Eu acho que é uma ideia extremamente consistente em algo que é realmente necessário e urgente para as ONGs. Extremamente viável. Então eu vejo o modelo de negócio funcionando de fato. Eu vejo que faz sentido tanto para os investidores, quanto para as ONGs.

P.09 Seria a possibilidade de profissionalização e transparência através da aproximação do potencial das redes com o terceiro setor?

R.09 A Prosa não tem aquela fotinho da criança sendo atendida ou tendo aula, porque nós não trabalhamos com o fim, com o público atendido. Nós trabalhamos o processo. Nós somos chatos porque trabalhamos com processos. Nós não temos este "olha que lindo que eles são porque eles ajudam ...

P.10 Mas este processo precisa existir...

R.10 Claro.

P.11 O que o potencial das tecnologias traz de fato para o trabalho social? O que elas trazem de novo ou potencializam? Seria o alcance? O potencial comunicativo?

R.11 Também, mas não só. Eu acho que a tecnologia altera comportamentos. O menino de 18 anos não decora telefone de cabeça. O jovem de 22 anos em São Paulo não sabe o caminho para chegar em Guarulhos porque ele vê tudo pelo Waze. A forma do jovem namorar hoje e de nos relacionarmos com as empresas é diferente. Então, muito mais que comunicação a tecnologia altera comportamento social e quem não perceber isso está ferrado. Muitas instituições não perceberam isso ainda. 
P.12 Ou enxergam, mas não conseguem se adaptar.

R.12 O governo é especialista nisso. Quando você vê um órgão que tem aí a idade média de funcionários com os seus 50 anos não percebe, não vai perceber e não vai se adaptar. Muito mais que comunicação e alcance, acho que é uma questão de alteração de comportamentos, de novas possibilidades, de mudanças mesmo, de tentar identificar oportunidades e tentar abarcálas para tentar fazer com que o setor consiga sobreviver. Eu acho que da mesma forma que os mercados estão se transformando, as economias que eram intermediadas não são mais intermediadas. Como o UBER, o OLX a TRIPADVISOR da vida estão retirando os intermediários e conectando diretamente o cliente ao fornecedor de serviço, eu acho que no setor social vai ser a mesma coisa. Para que precisamos de um consultor de captação de recursos, por exemplo? Para que precisamos de um consultor de elaboração de projetos? Por que não ligar já as pontas? A ONG com o investidor, o doador ao voluntário... Por que não ligar a ONG diretamente com o cidadão que precisa mais? Por que não o cidadão acompanhar o trabalho que esta ONG está fazendo de uma forma mais automática e transparente? Por aí vai... Então eu acho que as relações vão se transformar com as tecnologias. No setor social eu acho que a mudança ainda é muito devagar. No governo eu vejo até uma coisa mais rápida que no setor social, mas eu acho que eventualmente esses elos e essas conexões vão se transformar com as tecnologias.

P.13 Constroem novas sensibilidades?

R.13 Constroem novas formas de relacionamento, novas conexões. Eu não estou falando de redes sociais e absolutamente não estou falando de Facebook. "Face" não é uma ferramenta de conexão, é uma ferramenta de entretenimento, mas tem muitas outras ferramentas que estão surgindo que ajudam a conexão.

\section{P.14 Como você definiria o Prosas?}

R.14 É uma plataforma que conecta os atores da cadeia de valor de investimento social. Tem um monte de conceito abstrato aí, mas o Prosas está se propondo a fortalecer e a melhorar o investimento social conectando os atores da sua cadeia de valor.

P.15 Modelo de negócio?

R.15 Basicamente somos uma plataforma de seleção e monitoramento de projetos sociais. Então se a gente considerar três atores da cadeia: (a) investidor social, que é a empresa, o doador, etc; (b) a ONG, podendo ser também um empreendedor social pessoa física; e (c) o 
cidadão. Como conectamos esses três casos? Normalmente quando a empresa tem a sua atividade social e ela está preocupada em fazer investimentos sociais em ONGs, ela se interessa por doar ou patrocinar algum projeto social. Esta empresa tem muita dificuldade em encontrar ONGs qualificadas, de boa reputação, que elas sabem que vão usar bem o dinheiro delas. Pior ainda, uma vez que ela encontra esta ONG e ela quer acompanhar o que a ONG está fazendo com o dinheiro dela, ela encontra dificuldades de fazer este acompanhamento. Por outro lado. a ONG tem dificuldade de encontrar patrocinador, porque tem um bocado de ONGs disputando um recurso que escasso. Elas têem dificuldades de acessar esses patrocinadores e de se diferenciar das outras ONGs. O cidadão, por sua vez, está interessado em fazer com que o trabalho da ONG se fortaleça e tenha mais relevância. E ele também tem dificuldade em se conectar. Então o Prosas vem para resolver esses três problemas. Como? O patrocinador pode publicar os seus chamamentos de projetos no site do Prosas.

A gente trabalha com o fortalecimento do investimento social. A gente tem uma plataforma que faz com que as empresas se conectem e possam selecionar projetos de forma mais fácil. Somos uma plataforma onde vocês podem publicar os seus editais no nosso site e fazer todo o processo de gestão desses editais de recebimento de proposta, seleção, avaliação, etc, pelo site. Então basicamente a relação entre o investidor e a ONG tem o Prosas como um sistema de CRM, um sistema de gestão de parcerias, digamos. Além disso o cidadão consegue também recomendar os trabalhos das ONGs que acreditam, assim a relação entre a ONG e o cidadão meio que tem o Prosas como um sistema de recomendação. Então, por um lado, a gente é um S.A.P. Por outro lado a gente é um tipo Trip adivisor ou FourSquare, digamos assim. Por um lado, temos uma ferramenta de CRM, e, por outro lado, uma ferramenta de recomendações.

\section{P.16 Como a Plataforma Prosas monetiza?}

R.16 A gente vende a possibilidade de as empresas lançarem editais no Prosas e cobramos por isso. Nós temos diversos planos (básico, intermediário, avançado, tem por mês, anual, por edital, tem uma série de possibilidades). Mas esta não é a principal fonte de renda, a principal fonte de renda é a ONG. Como cobramos das ONGs? A gente trabalha em um modelo que as startups chamam de Freemium que é o free mais premium. Então todos os serviços essenciais do Prosas são gratuitos, a possibilidade da ONG buscar editais e se inscrever em editais é absolutamente gratuita. Fazer também o seu portfólio e divulgar o seu portfólio no Prosas é absolutamente gratuito. O que que é pago? Os serviços adicionais que podem ser úteis para a gestão da ONG, por exemplo a gente quer vender alertas personalizados de oportunidades que aparecem especificamente com o perfil da ONG. Então se o cara é uma ONG que trabalha com 
esportes em Santos e ele contratar este serviço ele vai receber todo edital novo que sai nesta área. Ele vai receber um alerta. Para isso ele paga sei lá $\mathrm{R} \$ 20,00$ ou $\mathrm{R} \$ 25,00$ por mês. Isso ainda nem está pronto. A gente também quer oferecer um sistema de gestão financeira e de projetos online adaptados às necessidades do terceiro setor. Hoje em dia temos muitos softwares para empresas que têm a questão de lucros, receitas, etc, que não faz muito sentido para ONGs. As ONGs têm muitas dificuldades de gestão e muitas delas têm dificuldades com tecnologia. A gente está desenvolvendo um sistema, estamos testando este sistema esta semana, que vai facilitar a gestão financeira das ONGs. Nele os campos são mais adequados e intuitivos de se mexer e é uma forma de prestar conta de suas ações aos investidores por este sistema. Para isso vamos cobrar também uns $\mathrm{R} \$ 30,00$. Então assim os valores são muito baixos e a gente quer trabalhar com a calda longa. Então, quanto mais gente na plataforma, mais conteúdo ela vai ter, mais editais ela vai ter e mais ONGs vão querer contratar esses serviços. Então a gente quer ir no volume mesmo.

P.17 Hoje a plataforma é beta?

\section{R.17 Sim}

\section{P.18 Desde?}

R.18 Junho de 2015. Muito pouco tempo. Nós temos 2.300 cidadãos cadastrados, umas 600 ONGs mais ou menos, temos também um pouco mais de 600 editais cadastrados na plataforma que colocamos manualmente. De clientes, ou seja, de processos de seleção e acompanhamento que rodaram na plataforma foram quatro: Instituto Sabin, SulAmerica, um projeto apoiado pela Ambev e um projeto apoiado pela Gerdau. Todos eles com resultados bem interessantes e satisfatórios.

P.19 Quão distante hoje é o seu modelo de negócio do modelo inicial? Usando o vocabulário do mundo startup. Esta é a primeira hipótese?

R.19 Este modelo é um pedacinho do modelo inicial. É o que o mundinho chama de MVP que é o produto mínimo viável. As startups falam muito assim, você tem uma mega ideia incrível e maravilhosa, mas vamos fazê-la inverter para testar que seria assim, o básico e necessário que precisa para você começar um negócio. Isso é muito interessante porque não adianta ficar criando um projeto maravilhoso para lançar porque você nunca vai lançar. Então faz o básico, lança já, vê se está funcionando e começa a acrescentar coisas e alterando. O que está no ar é o 
mínimo. A gente imagina sei lá, por exemplo, um mega sistema de recomendação do cidadão, trocas de ideias do que eles estão achando daquela ONG, de como ela pode melhorar o seu serviço, geolocalizar todas as ONGs, colocar no mapa para o cidadão localizar mais fácil a ONG que ele quer atuar. A gente imagina, por exemplo, um sistema de crowdfunding adaptado. Já temos para isso um banco de dados bem relevante de ONGs. Então por que não lançar um sistema de crowdfounding, onde a ONG fala qual é a sua necessidade e o cidadão que se identificar com aquela necessidade pode doar um dinheiro para ela? Enfim, a gente imagina um monte de coisa para o futuro. Por enquanto, o que está no ar é o básico e a gente está testando o modelo ainda. Por isso ainda somos beta e acho que seremos beta pra sempre. A ideia é a evolução contínua da plataforma.

P.20 Para você que vem empreendendo em diferentes contextos, esta possibilidade de apresentar protótipos e ir testando hipóteses junto ao mercado são novidades deste ecossistema startup?

R.20 Eu acho que não sei. Nos usávamos isso muito em Minas, mas era muito inspirado neste ambiente de inovação.

P.21 Já existia então esta postura de: tudo bem, não precisa estar pronto.

\section{R.21 É.}

P.22 Então a ideia no mínimo produto viável, protótipos e teste de hipóteses apresentadas hoje como metodologia startup de certa forma intuitivamente já era praticada? Não seria uma novidade do empreendedorismo startup?

R.22 Ah, eu acho que é uma novidade, sim. Eu acho inclusive que grandes corporações estão tentando adotar também, porque é uma forma muito... eu não sei conceitualizar direito pra você, mas eu acho que... e eu também não sei até que ponto a tecnologia possibilita de fato a gente a chegar neste contexto. Mas a possibilidade de uma startup de ter uma ideia e de testar rapidinho e ver se vai dar certo ou não (se der certo aumenta e se não der, para e muda de ideia) é muito característico das startups, mas eu não sei até que ponto a tecnologia é a culpada disso.

P.23 Redução dos custos?

R.23 Talvez... porque é fácil de testar... enfim... não sei o porquê. Mas eu acho que isso é uma novidade, sim. Para o governo isso é maravilhoso! Normalmente uma política pública tem que 
nascer já pronta, completa, complexa, caríssima e atendendo toda a população. Se você não tem tempo de testar ou ela dá errado, ou seja, um projeto já pode nascer morto, porque ele não foi testado e ele já é gigantesco e aí não deu certo, meu, acaba tudo ou continua mesmo dando errado porque tem um preço muito grande cancelar. E aí a galera de Design Thinking fala muito disso. O que pesa é um pouquinho de modinha, dá um pouco de preguiça, tem muito picareta, mas por outro lado quando é muito consistente e bem feito é importante. Enfim, resumindo, não acho que é uma modinha. Eu acho que é extremamente útil.

P.24 Então seria uma parte do processo que de certa forma caracteriza o empreendedorismo startup?

R.24 Acho que sim. Não só de testar, mas de testar de uma forma rápida, barata e com a chance de se der errado: para tudo, recolhe e vamos partir para outra. Tem um monte de gente que trabalha aqui no Cubo e diz: "puta, em setembro era assim, mas já mudei porque não deu certo". É incrível isso!

P.25 É muito comum que seja assim...

R.25 Sim... e é bom!

P.26 E esta aproximação das grandes empresas com as startups. O próprio espaço Cubo é uma realização de grandes empresas como Itaú e Unibanco, por exemplo. Seria iniciativa como esta uma tentativa de terceirização da inovação, uma vez que a máquina burocrática dessas grandes corporações não teria esta velocidade e desprendimento percebido nos modelos startups?

R.26 Eu não sei se é terceirizar. Eu acho que é mais tentar aprender.

\section{P.27 Aprender?}

R.27 Sim. Eu não sei se dá para terceirizar a inovação. Não sei direito. Eu acho que o Itaú está desenvolvendo o Cubo para aprender com as startups e eventualmente para agregar startups ao seu corpo. Mas não acho que seja terceirizar, não.

P.28 Como é realizado o acompanhamento da execução de um projeto? É físico também?

R.28 Nós temos uma equipe que acompanha todo o desenrolar do processo. O que está dando certo, o não previsto, a questão de relacionamento com o cliente. Todo o processo é acompanhado offline. Acho que não tem esta distinção. Não faz sentido esta separação off e online. Temos, sim, uma equipe que acompanha e alimenta. Por exemplo, quando um 
patrocinador entra e divulga o seu edital no site, tem todo um trabalho nosso de adaptar este edital a plataforma e fazer com que o patrocinador entenda o que a plataforma pode oferecer. Por outro lado, a ONG, quando ela está cadastrando projetos, nós também acompanhamos, vemos se o questionário faz sentido para as ONGs, quantas ONGs estão se escrevendo. Atendemos também as ONGs com dificuldade de informática. Tem todo um acompanhamento físico, sim.

P.29 A equipe fica em Minas?

R.29 Aqui fica só eu e Bruno, co-fundador.

P.30 Quantas pessoas na equipe?

R.30 São sete. Desenvolvimento, atendimento, financeiro, designer e demais sócios.

P.31 Por que ser um residente Cubo?

R.31 O cubo era uma possibilidade incrível de conexão com o ambiente de startups, com o ambiente de empreendedorismo. Tem muita gente interessante trabalhando aqui e muitas oportunidades. Visita de liderança do Itaú!

P.32 Faz diferença estar em um co-working?

R.32 Faz.

P.33 É rede?

R.33 Sim, é rede. O que pesa é que as startups são muito diferentes umas das outras, acho que os desafios são muito semelhantes. Por exemplo nós somos um negócio B2B e várias empresas aqui são. Às vezes os públicos são semelhantes, embora os projetos sejam diferentes. Acho que aqui as trocas são ricas.

P.34 Quanto tempo estão aqui no Cubo?

R.34 Cinco meses.

P.35 Parece-me que, em seu processo seletivo, o Cubo reconhece a base tecnológica das startups como requisito para acesso ao espaço...

R.35 Acho que sim. 
P.36 Você acha que a tecnologia define a startup? Ou qual o seu conceito de startup?

R.36 Startup são negócios, podem ser ideias, podem ser negócios já com CNPJ constituído, podem ser negócios já como clientes. Independente. São negócios que tem necessidade de crescimento rápido com muita escala. Para ter isso a gente precisa ter, não necessariamente precisa, mas na maioria dos casos a gente precisa de tecnologia para ter escala e crescimento rápido.

P.37 É isso...

R.37 Mas nem todo projeto de tecnologia é uma startup, sei lá, se não tem escala ou se...

P.38 Mas por que precisa ter esta escala?

R.38 Conceito de startup é uma ideia que pode crescer muito rápido... pode impactar muita gente, pode ganhar muito dinheiro, pode ter muito resultado.

P.39 É como se fechasse um conceito e você atendendo a ele você é uma startup?

R.39 Sim. É desta forma que eu entendo.

P.40 É uma cultura? Uma metodologia?

R.40 Metodologia não, cultura talvez. É um tipo de comportamento que surgiu com a tecnologia. É um tipo de negócio que a tecnologia vem aí transformando. Mas metodologia de fato não é. 


\section{APÊNDICE D \\ TRANSCRIÇÃO DE ENTREVISTA INTENSIVA IV}

\begin{tabular}{ll}
\hline ENTREVISTADO: & Rosi Rodrigues, co-fundadora da IUGU \\
\hline LOCAL: & São Paulo, SP \\
\hline DATA & Jan 2016 \\
\hline
\end{tabular}

P.01 Logo nesta primeira página do site IUGU vocês comunicam a intenção de potencializar a nova geração de negócios online?

R.01 Esta chamada não é só uma chamada publicitária. Ela está dentro da nossa missão de porquê que a IUGO nasceu. Esta afirmação é o que nos faz, no termo mais macro da organização, acordar pela manhã e trabalhar. Esta é a missão quando começamos a produzir a IUGO. E entrando nos detalhes de como a gente descobriu. Quando a gente nasceu e estava criando este negócio que iria potencializar os negócios digitais. Primeiro que vem muito desta questão da base tecnológica, né? Então assim, aqui na organização os fundadores iniciais, que são o Patrick e o Marcelo, eles têm background totalmente técnico. São pessoas muito técnicas que em suas jornadas diferentes... O Marcelo tem uma jornada muito mais para o lado corporativo. Ele desenvolvia software para SAP. SAP é uma empresa gigante super tradicional que constrói RP para outras organizações. Então são sistemas bem complexos para otimizar toda a parte operacional de uma organização. Aí vem o Patrick, que é uma pessoa muito mais inovadora, da era da internet mesmo, que gosta muito de jogos, ele desenvolveu na era pré Google uma ferramenta de busca. Então ele teve muito nesta época dos primórdios da internet, sempre via esses movimentos, o que é que a tecnologia podia facilitar a vida das pessoas. Quando os dois se juntaram, os dois perceberam. O Marcelo com seu conhecimento técnico muito forte em termo que eu crio o software para otimizar os processos de empresas. As empresas hoje em dia são todas automatizadas. Claro, você começa no manual quando você é uma empresa pequena, mas depois as coisas começam a entrar em um nível muito mais tecnológico. Você precisa de um servidor para guardar os documentos da empresa. Você precisa de um software que vai agilizar a comunicação de como o funcionário troca as informações de um projeto que está sendo feito com o outro, desde gestão de tarefa à construção de processos. Tudo isso a tecnologia para as empresas operarem de forma mais ágil, mais otimizada e utiliza melhor os seus recursos. O Marcelo com esta visão de olhar para empresa e tentar otimizar 
processos. Junto com o Patrick eles disseram "ah vamos criar software que vai facilitar a vida das empresas porque tem vários negócios digitais novos crescendo". Não sei se você conhece tem um software chamado Zendesk, que é um software para auto-atendimento. Para facilitar que quando alguém entre no seu site, contrate uma empresa, como eu posso administrar todo este material de suporte desde gente até toda a base de conhecimento e suporte da empresa. Daí eles começaram a criar um modelo parecido com o Zendesk. Mas todo software quando você está falando de software como um serviço, que a gente entende que são os novos modelos de negócios digitais...

Vou pausar a história e te contar o que é software como serviço. Antigamente quando você precisava comprar um software para o seu computador você ia em uma loja de venda como uma Kalunga e você comprava o software de caixinha. Uma vez que a cloud, que é a nuvem começou a vir à tona, as empresas de software não viram mais a necessidade de disponibilizar o software nesse formato de disquete ou CD. Vamos disponibilizar na nuvem e as pessoas acessam o link e baixam este software. Então existiu uma migração e a partir daí foi avançando esta possibilidade de oferecer software como serviço e em vez de você baixar o software, a web, sem a complexidade e instalações e versões que ocorre para baixar o programa.

Ah, então por que não fazer uma ferramenta que ela fica disponível para acesso na web e as pessoas nem sequer precisam instalar nada em duas máquinas? Então o software de caixinha sai da caixinha e vai para a cloud e agora vai para a web, que se chama de aplicativos web. Então pra oferecer um serviço que a pessoa utiliza na própria web, qual vai ser o meu modelo de negócio? Como eu vou cobrar dessas pessoas? Porque antes a cobrança era pela licença, era proprietário. Depois, conforme o formato foi evoluindo, foi evoluindo também o modelo de cobrança. E nesta escala de evolução o software chegou a uma cobrança que a gente está muito vendo, que são as assinaturas. Então ao invés de cobrar uma paulada na cabeça do cara, porque era cara a licença, então eu vou cobrar uma assinatura e na assinatura eu posso cobrar bem mais barato. São várias startups fazendo soluções web e oferecendo esses modelos de pagamento por assinatura. E os modelos de pagamento também estão evoluindo. Não só o modelo de pagamento em termo de o formato do pagamento. Como as pessoas pagam, então eu tenho o Paypal, cartão de credito, crowdfunding... então eu tenho como as pessoas querem pagar e também como as empresas vão tentar fazer novas formas de receita. Isso que nós chamamos de novos negócios digitais.

Quando uma empresa digital se dispõe a criar um software com esses novos modelos, qualquer que seja, por exemplo, você tem o Conta Azul que é uma startup brasileira que oferece uma 
solução web para a pessoa fazer toda a gestão financeira da sua pequena, grande ou média empresa. Então eles cobram uma mensalidade de 79 reais e a solução deles é oferecer esta gestão de fluxo financeiro. Assim, o software para controle de contas a pagar e receber não está instalado na máquina, mas sim disponível na web, onde todo mundo da empresa tem acesso sem precisar instalar nada. Existe um outro modelo chamado resultados digitais, empresa brasileira também que está fazendo um software de marketing onde as empresas de departamento de marketing podem enviar newsletter, notificações, fazer suas ações de marketing com o objetivo de aumentar as conversões dessas empresas em termos de marketing digital. E novamente as empresas têm um software em que ele paga uma mensalidade e usa aquilo entrando com login. Essas empresas, quando elas pensam em construir os seus produtos, elas não pensam nas dificuldades de faturamento que elas precisam ter, elas só pensam que o meu core business é marketing digital, só que pelo fato de eu ser um negócio totalmente digital, eu tenho que ter uma skill dentro de casa, um software, uma gestão interna de fazer o controle de faturamento disso. Isso porque antigamente eu ia na Kalunga e dizia: "Kalunga, eu tenho aqui mil licenças de software eu posso deixar aqui ou vendo para você e você revende". Hoje não é isso, hoje você precisa ter uma gestão de faturamento para vender essas assinaturas e novas métricas. Ao passo que os novos negócios digitais estão evoluindo, que as pessoas estão evoluindo no relacionamento dela com esses serviços online também evolui as métricas. Quando tempo ele fica na sua plataforma? Qual a média de gasto? Taxa de cancelamento, qual a taxa de retenção. O que o cliente na sua plataforma representa de receita. Tudo isso ele precisava evoluir o lado dele. Isso porque o modelo de cobrança mudou e por isso mudou o relacionamento dele com o cliente, com relação do faturamento, e aí eles pensaram no primeiro momento: "Bom, tem um monte de negócios digitais nascendo e as pessoas não têm esta skill de todo o processo de faturamento delas, a não ser que você seja uma empresa que faz faturamento então você vai ter essa skill dentro de casa. Então, vamos fazer um software que vai facilitar a potencialização dos novos negócios digitas. Vamos criar uma ferramenta que vai facilitar a vida deles neste processo de faturamento, neste processo de gestão de cobrança em geral. E assim deixamos o empreendedor focado naquilo que o empreendedor precisa entregar para o cliente dele. Então ele não precisa criar um software do zero só para desenvolver a sua cobrança." A gente pluga com ele que é a questão da evolução, né? É feito por integrações. Então eu não preciso construir um software igualzinho ao seu para que eles se comuniquem, eu posso construir o que chamamos de API que é a comunicação intermediária entre dois sistemas, ou seja, essa comunicação vai exatamente do meu para o seu. Então este é o conceito macro que está por trás dos novos negócios digitais. Novos negócios digitais porque os formatos da 
tecnologia mudaram, a relação das pessoas com a tecnologia mudou. Antigamente eu comprava o software e instalava na máquina, então eu não tenho algo tangível na minha mão e sim algo que eu acesso. Então a relação da construção dos negócios também foi afetada por isso porque na construção do negócio precisa levar em consideração o tempo de desenvolvimento, o custo para desenvolver tudo isso, então, a relação com o negócio sempre é alguma coisa mais ágil possível e de menor custo que vai causar menos impacto financeiro na minha empresa e vai propiciar que eu tenha um pouco mais de margem no meu negócio. Então esta relação com os novos negócios digitais também mudou. Isso é de onde vem a nossa missão. Essa parte de faturamento que fazemos hoje, que é a questão do pagamento online, é um dos blocos que a gente visa proporcionar para o empreendedor. Então hoje estamos trabalhando nesta caixinha, mas no futuro gostaríamos de trabalhar com outras caixinhas. É como se fosse: você quer criar um negócio digital? Então quando você vai construir uma casa você precisa da fundação, não é? São os blocos básicos que compõem o negócio. Então nosso objetivo é partir deste princípio.

P.02 É a identificação de um problema real, mas ao mesmo tempo trabalhar com uma demanda que de certa forma é bastante emergente deve ser um desafio diário, não?

R.02 É um desafio diário, mas ao mesmo tempo não é. Porque no nosso caso a gente vive muito na beira da inovação. Então estar na beira da inovação nos propicia estar um passo à frente e antevendo para onde a tecnologia está indo.

P.03 Vocês hoje trabalham 100\% com startups, correto?

R.03 Sim, hoje nós somos uma startup neste nosso momento de vida. Por que a startup em si tem vários pilares que definem a startup desde o seu modelo de negócio, que é aquela coisa "sou repetível e escalável". Tem o negócio digital, que está no mercado de incerteza também, desde a questão da cultura e tudo mais. Então hoje somos uma startup e oferecemos um serviço que também é para startups, porque os únicos clientes que conseguem compreender melhor a nossa proposta de valor também são startups, também são outros negócios digitais que conseguem compreender a necessidade dessa evolução do negócio e de porque ao invés de fazer em casa, ele vem para a IUGU porque ele vai ter mais agilidade, enfim, todas as coisas que tentamos oferecer para ele.

P.04 Como objeto de pesquisa a startup não é uma grandeza cientifica. Qual a sua concepção? R.04 Nos meus últimos quatro anos eu venho trabalhando com startups e eu iniciei o meu envolvimento neste ecossistema de inovação, empreendedorismo e tecnologia. Dentro de todas 
as startups com quem eu tive relacionamento e dos programas que tive oportunidade de coordenar - que foram nove programas dentro do startup farm; cada um deles tinha de 13 a 14 startups participando do programa e cada startup tinha de 03 a 05 empreendedores participando - então em média, em cada edição, tínhamos cerca de 40 a 50 participantes construindo cerca de 12 a 15 startups. Então, dentro desta experiência, o que eu compreendo como startup ela está muito ligada à base tecnológica.

P.05 Por que?

R.05 Pelo simples fato que o objetivo dela, o modelo de trabalho dela é dentro da escala operacional, dentro de algo que é escalável. E você só consegue fazer algo escalável com tecnologia, por que o princípio básico de escalar algo é que você consegue crescer. Vamos usar o WhatsApp: ele é uma empresa que revolucionou a comunicação entre as pessoas em diversos países no mundo. Ele tinha, antes de ser comprado pelo "Face", não mais que 50 pessoas provendo um serviço de grande impacto. Você, um número de demanda de servidor e equipe gigantesco. Se esta empresa tivesse que crescer o seu recurso no tamanho que ela expande o seu negócio, ela seria uma empresa multinacional como uma IBM da vida, com milhões de funcionários, mas não. Até a sua venda, o aplicativo tinha não mais que 50 pessoas. O que isso significa? Significa que, ao passo que ela cresce, você não precisa crescer em termos de recursos. Na verdade, quanto mais você avança, mais barato o negócio fica. O custo mais barato e mais margem de lucro você tem. Isso é o conceito de escalável. E aí a startup cresce para cumprir este objetivo. O objetivo de ter o business escalável.

Aí tem um outro conceito que é a inovação. Ela está ligada à inovação. Quando você tem um projeto embrionário que o objetivo dele é causar impacto, então os mercados em que a startup entra não são mercados pequenos. Você pode ter até varias variantes, tipo "ah, o mercado é novo", mas o mercado não tem impacto.

Para você conseguir oferecer escala você precisa ter impacto e para ter impacto você precisa de mercado grande. Então você tem aí a necessidade da inovação porque é um negócio novo. Se houver um precedente neste mercado, você pode estar tentando fazer melhor algo que já existe que não é feito de forma boa e você quer melhorar. Ou você pode estar criando algo novo do zero. As inovações que as startups se propõem a fazer são inovações com impacto. Só que o impacto só vem com isso que eu te falei. A tecnologia te dá o como você vai conseguir se expandir, se espalhar, como você vai conseguir gerar lucro a curto prazo, ter uma boa margem. Para mim está extremamente conectada à base tecnológica e com a inovação.

Aí depois que você cresce e vêm outras pessoas no mercado tentando replicar o seu modelo, existem precedentes neste mercado, precedentes de como é esta cadeia, como esta cadeia 
funciona, quais são os custos dessa cadeia, tudo isso que você está tentando pavimentar sozinho quando você está sozinho criando um business novo. E aí quando você cresce e tem precedentes, aí não necessariamente você é uma startup. Você pode se relacionar como uma startup porque você tem uma cultura empreendedora muito grande. Daí tem a coisa da cultura. A cultura, ela pode permanecer, mas a fase da empresa como startup não mais. A cultura de inovação, ela agiliza os processos de como as pessoas se comunicam, como agarram e defendem os projetos, com a coisa de desafio, de criar e fazer junto. Isso diferencia uma empresa que é ágil e inovadora de uma empresa que é tradicional.

P.06 O desafio ao status quo é uma consequência ou uma intenção?

R.06 Eu acredito que seria uma pretensão muito grande querer mudar o status quo. Eu acho que a mudança do status quo é uma consequência. Quando o empreendedor começa a criar o seu business até existe uma maneira romântica de mudar a vida do seu cliente, mudar a vida daquele que vai pagar para mim. Então eu vou mais no micro e não no macro. Existem esses posicionamentos macro como o Uber, mas para mim são poucos os negócios que levantam esta bandeira.

P.07 As nossas startups estão mais no perfil de aproveitamento de oportunidade ou de inovação?

R.07 O que eu sinto é que a minha percepção é que os negócios chegam por oportunidades inicialmente. Ao passo que o empreendedor vai cavando, pesquisando, entendendo mais o seu mercado e oportunidades. Ao passo que ele vai cavando neste processo de validação e construção da startup. Surge, sim, a possibilidade de criar um pitch mais para o lado da inovação. Ele se sente mais íntimo da inovação. São poucos os empreendedores que eu senti até o momento que chegam com este cunho da inovação. Isso talvez seja uma questão da própria cultura do brasileiro com relação à inovação. Inovação para brasileiro ainda é "bicho grilo". Na minha atuação de aceleração eles chegam muito mais com a intenção de criar negócios por oportunidade: "ah, é porque eu trabalho no ramo e tem essa oportunidade". Mas no meio do processo a chave virava em termos de quero galgar algo mais inovador, quero galgar uma proposta um pouco maior que funcional que seria resolver um problema, uma oportunidade. É claro que no Brasil temos muitas oportunidades e com certezas iremos galgar um caminho de empreendedorismo mais para o lado da oportunidade e paralelamente perceber que na oportunidade você pode encontrar a inovação. Mas, simplesmente pela invasão em si como nos 
Estados Unidos como um país de primeiro mundo sem ter as os problemas que o Brasil tem, então a cabeça do empreendedor está muito virada para oferecer coisas que são novas.

P.08 E quanto ao perfil desses empreendedores?

R.08 Você percebe isso no resultado das aceleradoras. Se você pensar que a nossa primeira geração empreendedora desse novo formato ainda não nasceu, ainda está em formação. Olhe, quando eu entrei nisso foi em 2011. Eu lembro dos primórdios, as pessoas que estavam fazendo a diferença na época que eu entrei, estavam batalhando ali no cenário de 2006 e 2009. Então, por exemplo o startup que é o único blog brasileiro dedicado a falar de startup nasceu em 2008. A Microsoft, que tem um dos programas mais elogiados de relacionamento com startups, começou ali em 2007. Silvia Valadares é responsável por este programa. Então esta primeira leva de pessoas que trabalhando com inovação... o fundo Criatec. que foi o primeiro fundo brasileiro que investiu em empresas de base tecnológica, que eram as startups da primeira leva, nasceu em 2008. Então você tem ali a primeira leva de formação dessa nova geração, uma movimentação ali de 2006 para frente. E ainda assim, o que temos de startups brasileiras que podemos dizer... o Peixe Urbano tentou mais faliu, foi vendido, teve toda esta decadência com relação ao modelo de negócio de compra coletiva e não foi só no Brasil que ele se mostrou insustentável, mas no mundo inteiro. Então eu ainda não vi a geração depois dessa leva nova que a gente começou a falar de empreendedorismo, a gente começou a falar de startups, que as redes sociais ficaram cada vez mais difundidas. Foi depois do Facebook para frente que passamos a compartilhar conteúdos relevantes e o papo começou a disseminar e aqueles que queriam fazer parte deste ecossistema começaram a se aproximar. Então, estamos no processo de formação ainda. Eu vejo, sim, que está acontecendo muito mais rápido que no ano 2000 e tudo mais, justamente porque a relação da pessoa com a internet e com as tecnologias mudou completamente. Só que realmente os empreendedores ainda estão em formação, vamos ver ainda as startups brasileiras que vão ser sucesso. Quem está quente hoje é a Nubank, mas ainda não é um unicórnio (startups que passam da linha de um bilhão na sua valoração). Tivemos a Buscapé vendida para a Napster que não é unicórnio, mas é a única que temos assim bem popular dessas novas que estão surgindo agora. 


\section{APÊNDICE E \\ TRANSCRIÇÃO DE ENTREVISTA INTENSIVA V}

\begin{tabular}{ll}
\hline ENTREVISTADO: & João Abussamra Neto, fundador da Wairon \\
\hline LOCAL: & São Paulo, SP \\
\hline DATA & Jan 2016 \\
\hline
\end{tabular}

P.01 Quais as suas experiências anteriores ou em paralelo à prática do empreendedorismo?

R.01 Eu caí meio que por acaso na área de TI, já sou um empreendedor do cabelo branco. A minha empresa anterior foi pioneira no software de comercio exterior. Nós criamos um software de comércio exterior aqui no Brasil. Eu tenho uma história legal lá porque eu fui de estagiário a programador, depois analista, supervisor, gestor, etc, e depois convidado a ser um dos sócios da empresa mais para frente. Então posteriormente uma empresa de Washington nos adquiriu. Foram 18 anos de história. Uma carreira empreendedora no modelo antigo, tradicional. Não tinha internet na época porque esta empresa eu trabalhei de 1985 como estagiário à 2002 e de 2002 a 2004 já trabalhei na multinacional, quando vendemos. É um empreendedorismo diferente. Nós criamos um conceito. Agora eu estou vivendo uma outra experiência dentro do empreendedorismo.

P.02 Que outra experiência? É diferente?

R.02 É um pouco, sim. Mas eu tenho uma capacidade de adaptação muito rápida. Mesmo tendo passado dos 50, eu me relaciono muito bem com a molecada aqui. Cansei do terno, é outra vida, é outro tipo de pegada...

P.03 Mas que diferença é essa?

R.03 Eu diria que ela é mais colaborativa. Não estou falando isso porque eu estou no Ccubo agora, porque antes disso quando eu comecei a ter contato com algumas startups, especificamente o Car Share, eu marquei um café com o André Marinho. Eu não tinha nenhuma contra-partida para ele porque eu estava começando e o cara falou tudo da empresa dele e eu disse "eu não acredito". Então a primeira quebra que eu tive foi essa. Os caras são mais na linha do vamos todo mundo juntos. Vamos desbravar este mercado. Ele está quebrando um paradigma e ele quebrando este paradigma me ajuda. O paradigma do compartilhamento. $\mathrm{O}$ Uber quebrando ali, o Airbnb quebrando ali, isso reflete para mim. 
P.04 Alterando comportamento?

R.04 Sim, alterando comportamento. E eu queria apresentar uma coisa para você. Neste mesmo tempo que eu comecei a falar de economia compartilhada e encontramos o nicho da Wairon, eu comecei a estudar bastante e eu criei uma página no "Face" de economia compartilhada e divulgo várias iniciativas de compartilhamento, mas ainda não pegou a dinâmica.

P.05 Mas você acha que a questão da economia compartilhada é um novo paradigma econômico ou é uma tendência, um comportamento, ou uma oportunidade de negócio?

R.05 Eu acho que ainda é uma tendência. Ela não se definiu porque ela não tem regulamentação. Então você pega o Uber para vir para cá e toma uma porrada. Aí tem uma outra questão que eu acho que tem um certo cartel de quem é dono das licenças e eles querem ver Carsharing e Uber mortos. E eles são muito fortes na Câmara Municipal. Tem espaço para todo mundo, porque as pessoas estão mudando seu conceito de posse. Isso é um fato. Na minha época, ter um carro era sinônimo de status e hoje as pessoas querem ter um carro para quando elas precisarem e elas não têm mais vergonha de dizer que alugou no Carsharing ou usou o Uber. Ou seja, mudou o conceito. É o paradigma da abundância, você tem impressão que você tem tudo. Então esse sentido de posse mudando acaba por mudar tudo.

P.06 Qual o conceito que vocês trabalham?

R.06 O conceito que estamos trabalhando com os nossos washers é que eles têm a oportunidade de ter um complemento de renda. Se ele conseguir montar uma estrutura. Eu conheci uma senhora que ela disse eu tenho uma casa na zona sul e nesta casa eu tenho uma estrutura para colocar três ou quatro máquinas de lavar. Então se por uma máquina ela consegue tirar por volta de 1.500 reais. Tudo isso fazendo em sua própria casa.

P.07 Como funciona? Vocês levam a roupa do usuário até o washer?

R.07 Nós temos a logística no meio terceirizada. É uma tremenda dor de cabeça.

P.08 Quem é seu público usuário alvo?

R.08 Temos várias situações, família que não quer lavar tudo em casa, máquina quebrou, e um nicho que estamos impulsionando no "Face” são os universitários e centros acadêmicos. 
Eu estou em uma fase que estou procurando muito early adopters. Eu comecei há duas semanas e já estou sentindo o movimento. Vai acontecer porque já sinto os e-mails perguntando. Sinto o movimento na página. Eu não estou preocupado. Vai acontecer. Mas o early adopter me ajuda porque ele começa a espalhar esta cultura. Nós dizemos que somos o Uber da lavagem de roupa. Nós estamos testando o modelo e percebendo o público, acompanhando os likes.

P.09 Quem são os concorrentes?

R.09 Temos um concorrente chamado "A Lavadeira". Mas temos também as lavanderias tradicionais na linha de preços. Lavanderias padrão franquias, que são muitos mais baratas. Estamos trabalhando na quebra de paradigma que é entregar sua roupa para levar para a casa de outra pessoa e não para o estabelecimento. Existe um aplicativo chamado "A Lavadeira" que ele faz uma programação que, por exemplo, toda terça e sexta ele capta a roupa e leva para uma lavanderia dele e leva no dia programado. Ele trabalha em um ciclo. Qual a desvantagem deste cara? Ele não escala, quer dizer ele pode escalar, mas é difícil. Ele está com esta operação em São Paulo, mas se quiser ir para o Rio de Janeiro vai ter que gastar tudo novamente para iniciar no Rio. Eu não preciso, porque eu não tenho parte fixa. Eu tenho o potencial de milhões de lavanderias espalhadas para o Brasil. Então qual que é o aspecto que eu tenho que tratar? Minha tendência é ir para Curitiba no segundo semestre. Inclusive porque a empresa que nos acelerou é de Curitiba. Qual é o meu plano? Eu preciso de um programa para encontrar os lavadores, trabalhando em sua casa e obter uma renda extra.

\section{P.10 Quem é seu cliente?}

R.10 O meu cliente é o washer e não o usuário. A minha plataforma é uma plataforma de intermediação. Eu não sou lavanderia. Minha razão social não é uma lavanderia. Eu presto um serviço ao washer encontrando um serviço e oferecendo uma logística para ele. O cliente é dele apesar de ele nem saber quem é. Se eu for lavar sua roupa você não sabe quem eu sou e eu não sei quem é você, mas a plataforma sabe. Mas você avalia o meu serviço, então se você avaliou mal, a plataforma sabe. Eu presto um serviço administrativo. E aí uma coisa muito importante é que meu washer é um microempreendedor individual (MEI). A contrapartida dele é abrir uma empresa, pagar um imposto por volta de 44 reais por mês. É uma exigência para ser nosso washer primeiro porque tem um aspecto social que queremos e não queremos incentivar a informalidade, embora eu tenha ido no Sebrae e os caras nem aí para mim. O meu contador faz a abertura do MEI para o washer como serviço. Eu estou dando o MEI, estou dando clientes e estou dando a logística para ele. Ele é meu cliente e ele simplesmente vai receber o dinheiro em 
caixa na conta dele e por que? Porque eu tenho um modo de pagamento no modelo marketplace que o dinheiro bate aqui e uma parte vem para ele. Ele não precisa fazer nada, só trabalhar direitinho.

P.11 Como o usuário paga?

R.11 O usuário faz o pagamento do serviço pela plataforma e do valor pago já se tem a fragmentação e o redirecionamento dos percentuais. Pagamos o modo de pagamento (trabalhamos com a IUGU), vai uma parte para a logística, a outra para o washer e outra parte para mim. A IUGU tem um marketplace bem feito que o dinheiro já é transferido automaticamente, sem bater e voltar e evita custos desnecessários de transações e transferências.

P.12 O seu equilíbrio e competitividade é possível?

R.12 Sim, porque eu não tenho o custo fixo de máquina, luz, água. Meu backoffice sou eu e meu sócio. Mas ele não fica alocado aqui, mas estamos ligados 24 horas. E eu tenho colaboradores, cada um na sua área, que estão espalhados por aí. Por exemplo, eu tenho um desenvolvedor, ele não é da Wairon, eu tenho um contrato com ele. Eu tenho uma aceleradora que nos ajudou a desenhar todos os processos e vai nos colocar em contato com investidores.

P.13 Como foi a sua experiência de aceleração? Você teve custo com elas?

R.13 Quando fechamos com esta empresa, tinha um valor e tinha um percentual. Então nós pagamos em dinheiro uma parte desta consultoria, digamos assim, desta aceleração, e a outra parte eles já ganharam porcentagem na empresa. E tem mais uma parte vesting que eles vão ganhar de acordo com a meta - meta vinculada à ajuda deles, nos colocando em contato com investidor e nos ajudando nesta negociação e no sucesso na negociação. O que foi legal da experiência com esta aceleradora? O desenho do processo em si eu teria me virado sozinho porque eu sou da área e minha vida inteira desenhei processos. Mas a aceleradora nos trouxe muitos atalhos. Eles indicaram muitas pessoas que nos ajudaram a acelerar. Por exemplo, eles que me apresentaram o Marinho, porque eles têm uma rede muito grande. Em uma conversa que eu tive com este cara ganhamos muito tempo. Estávamos indo em uma linha e o cara falou “não faz isso". Então o valor qualitativo desta consultoria não foi só o que ele entregou, porque por exemplo, dentro da consultoria tinha um designer que fez design da Wairon. Eles nos ajudaram a interpretar os resultados das pesquisas que fizemos, mas eu teria conseguido fazer isso, mas os contatos não? 


\section{P.14 Rede?}

R.14 Sim, o cara que é sócio desta aceleradora é forte lá no Anjos do Brasil e que traz muito conteúdo para nós. Fora que o processo foi recorde. A concepção da ideia foi em maio de 2015. Eu entrei em produção em janeiro de 2016 e eu só não entrei antes por um problema de infra e interpretação do módulo de pagamento. Ou seja, só seis meses. Eu acho que para a concepção de uma ideia, um desenho de processo e desenvolvimento é muito pouco tempo. Eu já desenvolvi muito, hoje não mais, mas para me enganar é difícil. Eu não desenvolvo mais, mas eu faço a gestão. Eu desenhei a solução e o banco de dados e passei para o programador. E o design veio da aceleradora. Claro que os caras agregaram muito...

P15 Para empreender neste ecossistema tem que ter uma pessoa de tecnologia?

R15 Eu vou te responder esta pergunta através de outro movimento que eu estou fazendo. Percebendo isso que você acabou de falar, eu percebi que eu posso fazer um tipo de aceleração mais intimista do que a que eu recebi. Assim, eu tomei porrada para caramba com o IUGU. Tomei porrada para caramba com infra. Bati cabeça de como formatar a empresa no nível jurídico, com nível contábil. Eu tenho um monte de conteúdo para chegar em você que teve uma ideia brilhante, mas que não sabe qual o próximo passo. Eu posso chegar para você com o pacote completo de consultoria para você, gestão do seu projeto e apoio técnico. Indo além. Vivenciamos isso. Teve uma menina que fez um movimento no grupo abc para a melhor ideia chamada de Beautifulclick e ela uma economia compartilhada de beleza. Nós tivemos um encontro e ela ganhou o prêmio, mas está parada porque ela não sabe como dar o primeiro passo. Ou seja, as pessoas têm a ideia e não sabem dar o passo seguinte. Por outro lado, o nerd é brilhante para fazer o aplicativo. 


\section{APÊNDICE F TRANSCRIÇÃO DE ENTREVISTA INTENSIVA VI}

\begin{tabular}{ll}
\hline ENTREVISTADO: & Márcio Boruchowski, fundador da Startup de educação Educare Br \\
\hline LOCAL: & São Paulo, SP \\
\hline DATA & Nov 2015 \\
\hline
\end{tabular}

P.01 Qual a sua concepção de startup?

R.01 Um caráter da própria startup é a velocidade com que ela tem que sair do chão. Diferente de uma microempresa, um mês depois uma startup pode ser uma outra coisa. Isto vem da própria definição da startup. A startup começa com a premissa de inovação. Como esta inovação tem este componente que você não sabe o que vai acontecer, você pode ter um monte de verdades que podem deixar de ser verdades, né? Empresa de tecnologia, pensada em escalar muito rapidamente, financiada por uma metodologia de escala, diferente de uma pequena empresa.

P.02 As tecnologias digitais definem a startup?

R.02 Para mim o uso da tecnologia não é o que define a startup. A startup vem mais do modelo de negócio e como ela aplica no seu mercado e no desenvolvimento dela mesma. O que a tecnologia trouxe é esta facilidade de conectar consumidores a consumidores. Para mim, o fato de se apoiar em tecnologias. Eu penso: eu e o Banco Itaú estamos usando e-mail. Claro que talvez o Banco Itaú tenha acesso a tecnologias mais caras, mas tirando estas grandes empresas, quase todo mundo tem acesso às mesmas ferramentas e elas são relativamente baratas e fazem coisas poderosas. Então o uso da tecnologia para mim não é o que define a startup. Para mim startup está muito mais ligada ao modelo de negócio e como ela aplica a tecnologia no seu mercado e nela mesma.

P.03 E no caso da Educare, como esta tecnologia participa dos processos?

R.03 Eu nasço como uma startup. Com esta prerrogativa de ser uma plataforma digital que conecta professores e alunos. Eu existo puramente online. Ninguém vem aqui, porque não tem nada para fazer aqui, assim como a 99taxi não tem nenhum taxista e a Airbnb não tem nenhum apartamento... 
P04. Esta é uma singularidade interessante. Parece que o corpo social da empresa muda completamente. Não existem muitos ativos fixos. Um trabalho imaterial...

P05. Pois é, nós temos uma parte pedagógica. Como eu trato com o professor de uma forma digital, virtual, às vezes esta melhor pessoa para contato não é o coordenador pedagógico, mas alguém que entenda de tecnologia. O ideal seria que entendesse dos dois, mas é algo muito difícil. Com os recursos limitados, quando precisamos de alguém para conversar com os professores, geralmente, eu contrato um coordenador pedagógico que entenda mais o modelo da escola, ou as vezes preciso contratar alguém que entenda mais de tecnologia ...

P.05. Você gera uma cadeia de competências?

R.05. Eu trabalho conforme minha operação vai tendo necessidade. Por isso eu sou completamente tecnológico. Eu posso estar aqui, como posso estar em qualquer lugar. Geograficamente, pouco importa onde eu estou.

P.06 Por que você decidiu empreender?

R.06 Eu busquei empreender por um misto de oportunidade e desejo. Oportunidade porque tinha caixa e desejo porque queria sair do ambiente corporativo. Eu já tinha empreendido antes. Empreender tem seus benefícios e suas dificuldades. Já participei também do mundo corporativo. Então, já participei dos dois ambientes. Quando em comecei com a Educare o ambiente dos negócios corporativo não estava muito bom e eu tinha acabado de sair de uma empresa com caixa suficiente para empreender. Eu estava procurando fazer algo próprio, então teve esta oportunidade e ao mesmo tempo que esta oportunidade partiu de questões como o ambiente externo corporativo, que não estava tão bom. Eu estava cansado dele, então eu pude empreender. No meu caso foi muito o desejo de sair do ambiente corporativo.

P.07 Por que o segmento na educação?

R.07 Empreendedorismo e educação. Acho que se dá por alguns fatores. Primeiro por que as pessoas que trabalham com educação geralmente têm uma certa paixão. Eu sempre trabalhei com projetos e organizações de impacto, que causassem uma transformação social. Eu queria trabalhar com algo de impacto. Eu já trabalhei com sustentabilidade, coisas que têm um impacto no mundo. Por outro lado, o segmento educacional se mostrou com muita oportunidade pra sofrer uma transformação por via tecnológica. Então foi uma união. E tem a paixão por educação. Eu sempre gostei de estudar e aplicar.

P.08. Qual a sua relação com as tecnologias digitais? 
R.08. Eu gosto de tecnologia do ponto de vista pessoal. Eu sou uma pessoa de exatas. Estudei engenharia na Poli.

P.09 Como as tecnologias digitais participam na Educare?

R.09 As tecnologias vieram romper com segmentos e modelos de negócios. A tecnologia Educare é uma plataforma onde as pessoas podem se cadastrar. Os professores se cadastram e recebem aulas. Então eles vão para um ambiente virtual de sala de aula. Os alunos se cadastram, pagam as aulas e conseguem se conectar ao vivo neste mesmo ambiente com o professor. Usamos as outras tecnologias para operação como e-mails e WhatsApp. Tem também o uso das tecnologias de gerenciamento, como CRM. Penso que a tecnologia vem trazer um ensino personalizado, vem trazer eficiência para o ensino e vem reduzir custos. E tudo isso acaba democratizando mais o ensino.

P. 10 Como se dá o processo de conexão demanda e professor?

R. 10 É completamente automático, senão não é escalável. São os algoritmos e os processos por detrás que realizam o trabalho.

P.11 Como seriam esses processos por detrás?

R.11 No ambiente virtual de aprendizagem, o algoritmo resolve questões e aceita o transporte de informações, recursos, ferramentas e inteligências. O conteúdo vem da rede, porque o importante não é o conteúdo, para isso temos o big data e as inteligências.

P.12 Quantas pessoas trabalham com você?

R.12 Somos uma empresa muito iniciante, no momento eu e mais cinco. Mas pode variar. Ainda estamos desenvolvendo a plataforma. E estamos no ar vai fazer cinco meses.

P.13. Como é a estrutura física do negócio?

R.13 Uso espaço de co-working, mas ainda tem muito do comando e controle. O uso do espaço de co-working não é uma particularidade das startups. A “virtualização” já acontece em muitas unidades de empresas grandes [adesão das empresas grandes]. Penso que este modelo não é uma resposta ainda, muitas startups são físicas e o trabalho junto ainda ocorre muito... 


\section{APÊNDICE G TRANSCRIÇÃO DE ENTREVISTA INTENSIVA VII}

\begin{tabular}{ll}
\hline ENTREVISTADO: & Jorge Vargas Neto, cofundador da Startup Financeira Biva \\
\hline LOCAL: & São Paulo, SP \\
\hline DATA & Mar 2016 \\
\hline
\end{tabular}

P.01 Quando eu te adicionei lá no LinkedIn, eu percebi que você tem competências nas áreas jurídica, bancária, investimento, etc. Qual a sua relação com o empreendedorismo, ou seja, como empreender se apresentou para você como uma possibilidade?

R.01 Desde pequeno convivi com empreendedorismo a partir do exemplo de meus pais, empreendedores da cultura e das artes. Quando já estudante da faculdade de direito, escolhi o direito porque sempre fui apaixonado pelo mercado financeiro e achava que o direito me proporcionaria uma visão ampla de todo o mercado. Me envolvi com algumas iniciativas de empreender, sendo que abri minha primeira empresa com 21 anos, empresa essa que acabou não dando muito certo, era uma holding de investimentos em outras empresas. Depois, ingressei em Pinheiro Neto Advogados e vi que ainda precisava me desenvolver muito. Após um tempo, adquiri certa maturidade, experiência e conhecimento que me permitiram criar a Biva, então com 25 anos, sendo o primeiro grande desafio a sua estruturação dentro do nosso complexo arcabouço jurídico/regulatório.

P.02 De que forma estas experiências precedentes te ajudaram na criação/desenvolvimento da Biva?

R.02 Como dito acima, o primeiro grande desafio da Biva era a sua estruturação vis-à-vis a regulação aplicável. Dada a complexidade de nosso mercado financeiro, por muitos anos acreditou-se que seria impossível trazer o fenômeno do peer-to-peer lending para o Brasil, assim, a partir de nossos conhecimentos adquiridos através de programas de pós-graduação e mestrado direcionados ao estudo do direito e práticas dos mercados financeiros e de capitais, bem como da prática continuada por anos na área de direito bancário de Pinheiro Neto Advogados e com o apoio/revisão de Bruno Balduccini, fomos capazes de criar uma estrutura adequada às regras aplicáveis e aceitas pelo Banco Central. 
P.03 Fale-me um pouco da sua experiência em empreender neste ambiente técnico e cheio de exigências regulatórias. Como você percebe o futuro do fenômeno Fintech no Brasil?

R.03 Empreender nesse ambiente não é nada fácil. Primeiramente pelas zonas cinzentas regulatórias, que são intrínsecas a novos modelos de negócios. Em segundo lugar, é muito difícil por conta da necessária simbiose que precisamos criar frente às instituições financeiras já estabelecidas. O terceiro, último e maior desafio é o de negócio, precisamos ter um grande produto, time e negócio para justificar os elevados investimentos que são necessários para criar qualquer plataforma de Fintech no mundo. Acredito que o fenômeno Fintech no Brasil está apenas em seu alvorecer. No Reino Unido e EUA esse fenômeno já tem mais de dez anos de história, por isso já foi devidamente regulado e os próprios governos apoiam e investem em algumas dessas iniciativas. Acredito que isso vai acontecer no Brasil, mas como dito, ainda estamos apenas começando. O Nubank, uma das primeiras Fintechs está apenas começando o seu terceiro ano de vida. Ainda há muita coisa boa vindo por aí para melhorar a vida financeira dos brasileiros.

P.04 Como a Biva foi pensada e concebida?

R.04 A Biva foi pensada e concebida por Paulo David, meu co-founder e eu para realizar uma revolução dentro do mercado financeiro para as pessoas que fazem parte dele. Biva significa: Bancando Ideias, Valores e Ações.

P.05 Como você define o seu negócio?

R.05 Somos uma plataforma que permite um novo jeito de investir ou obter financiamentos de forma mais eficiente (menos custosa), rápida e fácil do que o status quo.

P.06 Quão diferente é a Biva hoje da sua ideia e modelo inicial?

R.06 A Biva hoje é mais próxima de nossa ideia e modelo inicial, no início era apenas um sonho e um landing page, e queremos cada vez mais chegar próximos desse sonho de transformar a experiência financeira dos brasileiros.

P.07 Onde a Biva quer chegar?

R.07 Nós queremos criar um novo mercado financeiro (créditos/investimentos) para as pessoas que fazem parte dele. A ideia é semelhante à do Uber e do Airbnb. Não queremos roubar os clientes dos grandes players atualmente, mas sim trazer para o mercado financeiro pessoas que jamais tiveram essa experiência. 
P.08 Uma linha de uniformidade que estamos traçando em nossa pesquisa é esta espécie de desafio ao status quo que observamos em muitas iniciativas. Acredito que muito pelo fato dessas iniciativas estarem mudando modos de fazer as coisas ou sugerindo um novo modo de fazer as coisas. Iniciativas como Uber e Airbnb provocam um processo de descontinuidade no modo como fazemos as coisas. Com isso, observamos reações das mais diversas nos mercados tradicionais e institucionalizados, que podem ver a emergência desses novos negócios como concorrência, como irregularidade ou como um parceiro comercial. Como os bancos e instituições financeiras vêem a Biva? E aí não estou me referindo somente à autorização para operar, mas também no comportamento do mercado. Existe jogo de forças? Qual o nível de abertura?

R.08 Não vemos os bancos estabelecidos como competidores ou mesmo como os caras maus. Nós atuamos num segmento historicamente mal ou pouco atendido pelos grandes bancos. Isso se deve ao fato da limitação de dados disponíveis desses públicos (PMEs e pequenos investidores) e dos elevados custos para atendê-los combinada com uma pequena margem de lucro. Nós conseguimos fazer isso pelas inovações tecnológicas, financeiras e de ciência de dados que criamos, daí a ideia de que estamos criando um novo mercado. Acredito que os bancos nos vejam assim também.

P.09 Parece-me que o modelo de negócio em outros países não tem a exigência da figura da instituição financeira para realizar suas operações. Aqui vocês trabalham com parceiro? Como esta relação é articulada?

R.09 Sim. Temos contratos com alguns bancos parceiros que emitem os títulos bancários referentes às operações dentro da nossa plataforma.

P.10 Como as tecnologias participam das operações da Biva? Como funciona as atividades como análise de crédito e gestão das operações?

R.10 Infelizmente essa questão é sigilosa. A tempo e modo vamos passar a divulgar essas questões no nosso próprio site.

P.11 Como você definiria o papel da tecnologia no seu negócio?

R.11 A tecnologia possui um papel central no nosso negócio. 
P.12 Qual a sua relação com as tecnologias digitais?

R.12 Todos da Biva são grandes entusiastas de novas tecnologias digitais.

P.13 Qual o modelo de negócio?

R.13 Somos uma plataforma de peer-to-peer lending que é remunerada com uma comissão de $5 \%$ sobre as operações bem sucedidas de nossa plataforma.

P.14 Quantas pessoas trabalham hoje na BIVA?

R.14 24.

P.15 Quais os maiores desafios técnicos, operacionais, mercadológicos de desenvolver esta atividade empreendedora em rede?

R.15 Como dito acima, são três os grandes desafios: (i) lidar e se adequar às zonas cinzentas regulatórias que são intrínsecas a novos modelos de negócios; (ii) criação da necessária relação de simbiose com as instituições financeiras já estabelecidas e demais players de mercado; e (iii) desafios de negócio, que envolvem a criação de um grande produto, time e operação para justificar os elevados investimentos que são necessários para criar qualquer plataforma de Fintech no mundo. 


\section{APÊNDICE H \\ QUESTIONÁRIO INICIAL PARA ENTREVISTA INTENSIVA \\ Data: Jan 2015}

Esta entrevista está estruturada em dois blocos: (A) O empreendedor: neste primeiro momento ficaremos atentos às motivações, os desejos e as perspectivas do sujeito empreendedor, buscando entender como estas tecnologias alteram o acesso à atividade empreendedora, e quem são esses sujeitos? (B) A atividade empreendedora: no segundo bloco o nosso foco será voltado para a atividade empreendedora em si. Aqui o esforço será direcionado para perceber como as tecnologias digitais alteram a atividade empreendedora, buscando produzir dados que nos ajudem a identificar a qualidade da ação empreendedora no contexto de redes.

\section{(A) O empreendedor}

i) Quais as suas experiências antes ou em paralelo ao empreendedorismo?

ii) Como empreender se apresentou para você como uma possibilidade?

iii) O que é ser empreendedor para você?

iv) O que te motivou e o que te fez acreditar neste negócio?

v) Quais suas ações para tornar a ideia possível?

vi) Qual a sua relação com as tecnologias digitais?

vii) Qual a sua perspectiva quanto à startup?

\section{(B) A atividade empreendedora}

- A concepção

i) Como este negócio foi concebido?

ii) Por que empreender com as tecnologias digitais e não de maneira convencional?

iii) Quais as potencialidades que você identifica com o uso destas novas tecnologias?

- A estrutura

i) Quantas pessoas trabalham no negócio?

ii) Como é a estrutura física do negócio?

iii) Como estão organizadas essas pessoas? Disposições? Organogramas?

iv) Como estas pessoas executam as suas funções? 
- A tecnologia

i) Qual a tecnologia que participa dos negócios da startup?

ii) Como você definiria o papel da tecnologia em seu negócio?

- Os Processos

i) Como eu poderia mapear o seu negócio? Quem são os atores envolvidos e seus papéis?

ii) Como o trabalho é organizada? Existem processos estruturados?

iii) Como podemos descrever os processos envolvidos na startup?

iv) Como seria um típico dia de operações na empresa?

v) Você identificaria alguma desvantagem ou risco operacional em relação aos modelos tradicionais?

vi) Como você descreveria a importância da participação tecnológica nesses processos?

vii) Quais os maiores desafios técnicos, operacionais, mercadológicos de desenvolver esta atividade empreendedora em rede?

- O modelo de negócio

i) Qual o seu mercado de atuação?

ii) Qual o seu modelo de negócio?

iii) Como você definiria o seu core business?

iv) Qual o estágio de maturidade da startup?

v) Quão distante é hoje o seu modelo de negócio da ideia inicial?

vi) Quantas hipóteses foram testadas? 